MARIANA MIRANDA LIMA

\title{
A NATUREZA JURÍDICA DOS JUROS SOBRE O CAPITAL PRÓPRIO E AS CONVENÇÕES PARA EVITAR A DUPLA TRIBUTAÇÃO
}

Dissertação de Mestrado

Orientador: Professor Associado Heleno Taveira TôRres

FACULDADE DE DIREITO DA USP

SÃO PAULO

2009 


\section{A NATUREZA JURÍDICA DOS JUROS SOBRE O CAPITAL PRÓPRIO E AS CONVENÇÕES PARA EVITAR A DUPLA TRIBUTAÇÃO}

Dissertação apresentada à Banca Examinadora da Faculdade de Direito da Universidade de São Paulo, como exigência parcial para a obtenção do título de Mestre em Direito, sob a orientação do Professor Associado Heleno Taveira Tôrres.

FACULDADE DE DIREITO DA USP

SÃO PAULO

2009 
Banca Examinadora 
Aos meus pais. 


\section{AGRADECIMENTOS}

Foram muitas as pessoas que contribuíram, direta ou indiretamente, para a redação deste trabalho e certamente deixarei de lembrar-me de alguém, por mais que eu me esforce para fazer um agradecimento especial a cada um.

Sem que a ordem abaixo tenha qualquer significado de importância, gostaria de agradecer com toda a sinceridade:

Aos meus pais, exemplos de dedicação incondicional aos filhos, pela minha formação. Aos meus queridos irmãos, especialmente ao Mauricio e à Patricia, pelo constante apoio, incentivo e compreensão.

Ao Professor Heleno Taveira Tôrres, acadêmico de notável inteligência $e$ gentileza, por me despertar, ainda na Graduação, o gosto pelo estudo do Direito Tributário e por me aceitar como sua orientanda.

A Diego e Maria Helena Corapi, pelo incentivo inicial para o ingresso no curso de Mestrado na Faculdade de Direito da USP.

Agradeço especialmente a muito querida Clarissa Gianetti Machado, pelo estímulo para o ingresso e dedicação ao curso de Mestrado, por todo o incentivo no mundo do Direito Tributário e pela amizade conquistada; a Eduardo Martinelli Carvalho, pela incansável compreensão e constante incentivo, pelos aprendizados e pela nova amizade; a Professora Maria Apparecida Silveira pelo carinho e diligência com que revisou o texto; a Vicente Gomes de Oliveira Filho pela ajuda, sempre amiga, com a pesquisa; a Anna Lygia Costa Rêgo, a Giuliana Bonanno Schunck, a João Augusto Prado da Silveira Gameiro e a Nelson Jorge Pitaguari Germanos, pela paciente revisão do texto e valiosa troca de idéias; a Melissa Magnus, pela paciência com que me introduziu à ciência financeira; a Marcelo Bez Debatin da Silveira, por ouvir, pacientemente, todas as minhas lamentações; a Danilo Albuquerque Dias e a Ana Clara Freire Tenorio de Lima pela desprendida ajuda para o término deste trabalho.

Ao Roberto, pelo carinho, apoio e paciência. 


\section{RESUMO}

Esta dissertação tem o objetivo de analisar a figura dos juros sobre o capital próprio, especialmente para definir a sua natureza jurídica e adequada qualificação no âmbito dos acordos para evitar a dupla tributação.

Para tanto, além de fazermos uma digressão sobre o histórico de tal figura e os motivos da sua instituição, visando entendê-la melhor, estudamos, sob a perspectiva do Direito Tributário e também do Direito Comercial, as diferentes formas de remuneração do capital financiado por meio de capital próprio e de capital de terceiros, quais sejam: os dividendos e os juros remuneratórios. Analisamos detalhadamente as regras tributárias aplicáveis ao pagamento de juros sobre o capital próprio e também aquelas que definem a sua forma de cálculo.

Comparamos as particularidades dos juros sobre o capital próprio às figuras dos dividendos e dos juros remuneratórios, de modo a definir a sua natureza jurídica como espécie de remuneração de sócios, diversa dos dividendos. Criticamos alguns aspectos das correntes atualmente existentes sobre o assunto, justificando a nossa posição.

Analisamos, também, a forma adequada de qualificação dos juros sobre o capital próprio nos acordos para evitar a dupla tributação, especialmente em relação à Convenção Modelo da Organização para a Cooperação e Desenvolvimento Econômico (OCDE).

Ao final, concluímos que, a despeito de os juros sobre o capital próprio terem natureza de remuneração de sócios diversa da figura dos dividendos, para fins de aplicação dos acordos para evitar a dupla tributação, devem ser qualificados como dividendos.

Palavras-chave: juros sobre o capital próprio - remuneração de sócios - financiamento capital próprio - capital de terceiros - subcapitalização - imposto sobre a renda - tratados - dupla tributação - qualificação 


\section{ABSTRACT}

This dissertation aims at analyzing the interest on equity, especially to define its nature and proper qualification within the treaties to avoid double taxation.

For this purpose, in addition to the history of the interest on equity and the reasons that justified its creation, we study, from a Corporate Law and also Tax Law standpoint, the different kinds of remuneration of equity and debt, which is: dividends and interests. We also analyze in details the tax rules applicable to the payment of the interest on equity and the ones that provide for its calculus.

We compare the specificities of the interest on equity with the dividends and interests, in order to define its nature as a kind of equity remuneration, which may not be associated to dividends. In this regard, we criticize specific aspects of the existing understandings on the issue, justifying our opinion.

Moreover, we analyze the proper qualification of the interest on the equity within the treaties to avoid double taxation, in particular the Model Tax Convention of the Organisation for Economic Co-operation and Development (OECD).

We conclude that, even though the interest on equity is a kind of equity remuneration, which is different from the dividends, for the purposes of applying treaties to avoid double taxation, it should be qualified as dividends.

Key-words: interest on equity - equity remuneration - financing - equity - debt - thin capitalization - income tax - treaties - double taxation - qualification 


\section{SUMÁRIO}

INTRODUÇÃO

CAPÍTULO I. A SOCIEDADE EMPRESÁRIA E OS SISTEMAS DE CAPITALIZAÇÃO: A ORIGEM DOS RECURSOS FORMADORES DO CAPITAL APLICADO

1. A sociedade empresária, seu objetivo lucrativo e a assunção dos riscos da atividade pelo empresário

2. O financiamento das sociedades empresárias como pressuposto para o desempenho das suas atividades: as fontes de origem do capital aplicado e a natureza das correspondentes remunerações

2.1. A origem do capital aplicado: fontes de capital próprio e de terceiros. As vantagens e desvantagens do financiamento do capital aplicado mediante capital próprio e capital de terceiros

2.1.1. A opção pelo financiamento da sociedade com utilização de capital próprio ou de terceiros: vantagens e desvantagens

2.2. Subcapitalização: a necessária proporcionalidade entre o volume de financiamento mediante capital próprio e capital de terceiros

2.2.1. Os diferentes tipos de subcapitalização. A definição dos conceitos de subcapitalização nominal e subcapitalização material

2.2.2. As regras de distribuição de lucros no Direito Brasileiro e a distribuição de lucros ilícita como mecanismo de subcapitalização nominal.....

CAPÍtUlo II. O TRATAMENTO TRIBUTÁRIO DISPENSADO ÀS FORMAS DE REMUNERAÇÃO DO CAPITAL FINANCIADO POR MEIO DE CAPITAL PRÓPRIO E DE CAPITAL DE TERCEIROS. OS IMPACTOS TRIBUTÁRIOS DECORRENTES DA CARACTERIZAÇÃO DA SUBCAPITALIZAÇÃO NOMINAL

1. A dupla tributação dos lucros auferidos pelas sociedades e os métodos de integração tributária propostos para a resolução desta ineficiência econômicofinanceira

1.1. A análise dos métodos de integração propostos para a eliminação ou mitigação da dupla tributação dos lucros auferidos pelas sociedades. 
2. A solução do Direito Positivo Brasileiro para a eliminação da dupla tributação sobre os lucros das sociedades. Os métodos de avaliação de investimentos permanentes e as regras tributárias aplicáveis à distribuição de dividendos

2.1. A avaliação de investimentos permanentes: o método do custo versus o método da equivalência patrimonial

2.2. Distribuição de dividendos: a contabilização e os efeitos tributários decorrentes da remuneração pelo capital próprio investido

3. A análise tributária das vantagens decorrentes do financiamento por meio de capital de terceiros e dos efeitos da caracterização da subcapitalização nominal

3.1. O tratamento tributário dispensado aos juros decorrentes de empréstimos a sociedades brasileiras

3.2. A caracterização da subcapitalização nominal e os impactos tributários para a sociedade mutuária e para os sócios mutuantes

\section{CAPÍtUlO III. A NATUREZA DOS JUROS SOBRE O CAPITAL PRÓPRIO E A SUA UTILIZAÇÃO COMO MECANISMO DE ELIMINAÇÃO DO TRATAMENTO TRIBUTÁRIO DISCRIMINATÓRIO DISPENSADO AO CAPITAL PRÓPRIO}

1. Introdução à figura dos juros sobre o capital próprio . .78

2. Os juros sobre o capital próprio como custo de oportunidade e como mecanismo de equiparação de tratamento fiscal entre as remunerações dos capitais próprio e de terceiros

3. O tratamento tributário e contábil dispensado aos juros sobre o capital próprio.

Vantagem do seu pagamento ou crédito: previsão legal de dedutibilidade

3.1. O tratamento contábil dispensado aos juros sobre o capital próprio pela regulamentação da Comissão de Valores Mobiliários - CVM

3.2. O cálculo dos juros sobre o capital próprio e as controvérsias decorrentes da legislação vigente

3.2.1. Juros sobre o capital próprio calculados, creditados e pagos pelo regime de competência.

3.2.2. A exclusão do lucro do exercício do valor do patrimônio líquido a ser utilizado para o cálculo dos juros sobre o capital próprio

3.2.3. A necessidade de compensação de prejuízos acumulados para o pagamento de juros sobre o capital próprio 
3.2.4. As implicações decorrentes da existência de conflito de regramentos no valor dos juros sobre o capital próprio passível de pagamento.

4. A causa do financiamento por meio de capital próprio e a definição da natureza

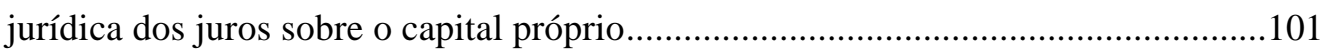

5. A figura da "déduction pour capital à risque" no direito positivo da Bélgica.....

\section{CAPÍTULO IV. A APLICAÇÃo dOS ACORdOS INTERNACIONAIS PARA EVITAR A DUPLA TRIBUTAÇÃO NO PAGAMENTO DE JUROS SOBRE O CAPITAL PRÓPRIO A RESIDENTES OU DOMICILIADOS NO EXTERIOR}

1. Breves considerações sobre a tributação de não-residentes pelo Estado Brasileiro ...109

2. Breves considerações sobre os acordos internacionais. O Modelo de Convenção

Relativa a Impostos sobre a Renda e o Capital proposto pela OCDE

2.1. A hierarquia entre as normas jurídicas internas e externas no Sistema

Tributário Brasileiro

2.2. Modelos de acordos internacionais destinados a evitar a dupla tributação internacional da renda

2.2.1. O conflito de qualificação no âmbito da Convenção Modelo da OCDE

3. A aplicação dos acordos para evitar a dupla tributação no pagamento de juros sobre o capital próprio a investidores residentes ou domiciliados no exterior: uma análise detalhada dos artigos $7^{\circ}, 10$ e 11 da Convenção Modelo da

OCDE

3.1. A qualificação dos rendimentos como lucros das empresas: a ausência de conceito na Convenção Modelo da OCDE.

3.2. A qualificação dos rendimentos como dividendos: o conceito previsto no artigo 10 da Convenção Modelo da OCDE

3.2.1. Os juros sobre o capital próprio e a sua relação com o conceito de dividendos previsto no artigo 10 da Convenção Modelo da OCDE

3.3. A qualificação dos rendimentos como juros: o conceito previsto no artigo

11 da Convenção Modelo da OCDE

3.3.1. Os juros sobre o capital próprio e a sua relação com o conceito de juros previsto no artigo 11 da Convenção Modelo da OCDE. As diferenças do conceito de juros adotado nos acordos firmados pelo Brasil 
3.4. O tratamento tributário dispensado aos rendimentos no âmbito dos artigos

10 e 11 da Convenção Modelo da OCDE

3.4.1. A atribuição de competência aos Estados contratantes em relação à tributação dos dividendos enquadrados no Artigo 10 da Convenção Modelo da OCDE

3.4.1.1. As soluções analisadas pela OCDE em virtude da dupla tributação econômica dos lucros das sociedades

3.4.2. A atribuição de competência aos Estados contratantes em relação à tributação dos juros enquadrados no Artigo 11 da Convenção Modelo da OCDE

3.4.2.1. O pagamento de juros a residentes no exterior e o principio da não-discriminação na Convenção Modelo da OCDE 


\section{INTRODUÇÃO}

A conjuntura atual está marcada pela globalização econômica, financeira e comercial, na qual as empresas transnacionais desempenham papel fundamental nos processos decisórios político-normativos. Isso porque o interesse das empresas transnacionais interfere na elaboração normativa, principalmente em relação aos incentivos para investimento.

No cenário mundial contemporâneo, os investidores, nacionais ou internacionais, buscam constantemente alternativas de investimento com alto retorno, pautadas na concessão de benefícios e redução de riscos, bem como nas condições favoráveis ao desenvolvimento de seus negócios.

Nesse sentido, a figura dos juros sobre o capital próprio, um instrumento atípico de nossa legislação, chama a atenção dos investidores, tendo em vista seu tratamento diferenciado assegurado pela Lei ${ }^{\circ}$ 9.249/95.

Os juros sobre o capital próprio têm sua origem em política adotada pelo Governo Brasileiro para incentivar a realização de investimentos por meio de capital próprio. Visam principalmente à eliminação do tratamento tributário discriminatório dispensado a esses investimentos quando comparados àqueles realizados por meio de capital de terceiros.

As vantagens práticas da distribuição de juros sobre o capital próprio atingem tanto a sociedade pagadora como o próprio investidor.

As sociedades investidas beneficiam-se diretamente por meio de concreta economia fiscal decorrente da previsão legal de dedução dos juros sobre o capital próprio para efeitos de apuração do Imposto sobre a Renda e da Contribuição Social sobre o Lucro Líquido. Em outras palavras, atendidos os limites impostos pela Legislação Brasileira, o lucro tributável da sociedade é reduzido pelo pagamento de juros sobre o capital próprio, culminando na diminuição da carga tributária que lhe é imputada.

Ainda, as sociedades brasileiras, mesmo sem estarem em posição de excedente de caixa, podem, mediante deliberação de seus sócios ou acionistas, creditar-lhes juros sobre o capital próprio e, conseqüentemente, deduzir o montante creditado para fins fiscais no correspondente exercício fiscal. 
Outra importante vantagem dos juros sobre o capital próprio é o diferencial das sociedades brasileiras no que se refere às formas de remuneração de seus sócios. Regra geral, essa remuneração se apresenta sob a figura dos dividendos, que não possuem o benefício tributário da dedutibilidade. Os juros sobre o capital próprio representam, portanto, uma alternativa à figura tradicional, podendo eventualmente substituí-la.

O investidor, por sua vez, será beneficiado pelo pagamento ou crédito de juros sobre o capital próprio em decorrência da economia fiscal obtida pela sociedade, i.e., reduzindo-se a sua carga tributária, essa sociedade obterá mais lucros que serão, conseqüentemente, distribuídos aos sócios.

Um recente estudo elaborado por Ari Ferreira Abreu comprova que o tratamento benéfico atribuído ao pagamento de juros sobre o capital próprio aumenta a remuneração do acionista de uma sociedade financiada por meio de capital próprio, sem incorrer nos riscos inerentes aos financiamentos concedidos por terceiros ${ }^{1}$.

Em termos práticos, verifica-se um crescente aumento do volume de pagamentos a sócios, residentes ou estrangeiros, sob a forma de juros sobre o capital próprio, o que demonstra que os investidores apreciam as vantagens da ferramenta de remuneração em referência ${ }^{2}$.

Em contraposição a todos esses benefícios, a incerteza quanto à natureza jurídica dos juros sobre o capital próprio tende a gerar insegurança no investidor, uma vez que as conseqüências legais podem ser diversas, dependendo da interpretação adotada.

O próprio Governo Brasileiro não é coerente quanto à natureza dos juros sobre o capital próprio. Enquanto a Receita Federal do Brasil afirma tratarem-se de juros propriamente ditos, o Banco Central do Brasil dispensa tratamento de dividendos aos juros sobre o capital próprio, uma vez que não permite a remessa ao exterior desse tipo de rendimento nas hipóteses em que a empresa possui prejuízos acumulados registrados em seus livros contábeis.

Essa problemática é especialmente danosa em relação aos investidores estrangeiros, uma vez que, quando da aplicação dos acordos para evitar a dupla tributação,

\footnotetext{
${ }^{1}$ ABREU, Ari Ferreira de. Um estudo sobre a estrutura de capital e a política de dividendos considerando a tributação brasileira. Dissertação (Mestrado) - Faculdade de Economia - FEA, Direito, Universidade de São Paulo, São Paulo, 2004.

${ }^{2}$ SANTOS, Ariovaldo. Quem está pagando juros sobre o capital próprio no Brasil? Revista de Contabilidade de Finanças, São Paulo, n. 43, p. 33-44, jun. 2007.
} 
é necessária a adequada qualificação dos rendimentos para a aplicação do coerente tratamento tributário. A qualificação inadequada dos juros sobre o capital próprio no âmbito dos acordos para evitar a dupla tributação pode implicar a completa ineficácia desses acordos no que se refere à mitigação ou eliminação dos efeitos da dupla tributação.

Diante do exposto, resta evidente a importância do tema em questão, principalmente para países em desenvolvimento, como o Brasil, como forma de incentivo ao investimento direto de longo prazo.

Nesse sentido, o presente trabalho tem o propósito de definir a natureza jurídica dos juros sobre o capital próprio e adequadamente qualificá-los no âmbito dos acordos para evitar a dupla tributação.

Para tanto, serão comentados os sistemas de capitalização de sociedades, destinando-se especial atenção às fontes de origem dos recursos aplicados, quais sejam: capital próprio e capital de terceiros. As características desses sistemas de capitalização serão detalhadas como forma de atribuir elementos à posterior análise da natureza dos juros sobre o capital próprio.

Em relação a cada uma dessas fontes de financiamento será apontada e detalhadamente analisada, sob ponto de vista do Direito Comercial e do Direito Tributário, a espécie clássica de remuneração aplicável, i.e., os dividendos e os juros remuneratórios, respectivamente. As figuras dos dividendos e dos juros serão estudadas, principalmente no que se refere à sua natureza jurídica e características intrínsecas. O objetivo dessa análise é obter meios para a posterior comparação de tais figuras com os Juros sobre o Capital Próprio, contribuindo para a definição da sua natureza jurídica. É importante ressaltar que, na seara tributária, esse trabalho terá foco apenas nas normas e conseqüências para o Imposto sobre a Renda.

Chegaremos depois à questão central deste trabalho: a figura dos juros sobre o capital próprio. Inicialmente, será relatado e comentado o contexto no qual foram instituídos, de forma a resgatar os objetivos reais de sua criação e de seu tratamento tributário diferenciado. Essa análise compreende um paralelo entre a figura dos juros sobre o capital próprio e a subcapitalização nominal. Ainda que o Direito Positivo Brasileiro não possua qualquer definição do estado de subcapitalização das sociedades, tampouco regulamenta os seus efeitos no campo dos Direitos Comercial e Tributário, conforme será 
demonstrado, é possível afirmar que os juros sobre o capital próprio estão intimamente ligados a esse estado da sociedade.

O cálculo dos juros sobre o capital próprio também será estudado, assim como as regras aplicáveis no âmbito tributário, especificamente em relação ao Imposto sobre a Renda, e os eventuais benefícios econômicos e fiscais decorrentes do seu pagamento. Isso porque, se pretende definir as especificidades da figura dos juros sobre o capital próprio frente às demais formas de remuneração de sócios, por meio da obtenção de elementos práticos inerentes a esses juros e, portanto, primordiais para a definição de sua natureza jurídica.

Serão então abordadas e detalhadamente analisadas as correntes doutrinárias existentes acerca da natureza jurídica dos juros sobre o capital próprio, contrapondo aquelas que entendem tratar-se de dividendos com aquelas que defendem a sua caracterização como juros remuneratórios, buscando definir cada um dos argumentos utilizados e refutados. O intuito dessa análise é detalharmos cada uma das características dos institutos dos dividendos e dos juros, já estudados previamente, em relação aos Juros sobre o Capital Próprio, obtendo, assim, suas afinidades, congruências e incongruências.

Finalmente, estudaremos a aplicação dos acordos para evitar a dupla tributação no pagamento de juros sobre o capital próprio a sócios residentes no exterior. Para tanto, será feita uma breve análise dos aspectos inerentes à tributação de não-residentes e da relação entre as normas tributárias de Direito Interno e Direto Internacional. Passaremos então a uma análise detalhada da Convenção Modelo da Organização para a Cooperação e Desenvolvimento Econômico, que será utilizada como base para a adequada qualificação dos juros sobre o capital próprio. Ressalta-se que este trabalho não pretende analisar cada um dos acordos firmados pelo Brasil para evitar a dupla tributação, mas apenas comentar particularidades que podem afetar o tratamento dos juros sobre o capital próprio. Também não pretendemos aprofundar o estudo em relação aos problemas de qualificação no âmbito dos tratados, uma vez que, no caso dos juros sobre o capital próprio, a problemática em relação a este assunto é pontual e direta, sem margem para controvérsias.

Por fim, apresentaremos nossas conclusões quanto à análise realizada, reafirmando os recorrentes entendimentos pessoais expostos sobre questões propostas ao longo do trabalho para definir que, apesar de os juros sobre o capital próprio serem espécie de remuneração de sócios diversa dos dividendos, esses rendimentos devem ser qualificados como dividendos para fins de aplicação dos acordos para evitar a dupla tributação. 


\section{CAPÍTULO I. A SOCIEDADE EMPRESÁRIA E OS SISTEMAS DE CAPITALIZAÇÃO: A ORIGEM DOS RECURSOS FORMADORES DO CAPITAL APLICADO.}

\section{A sociedade empresária, seu objetivo lucrativo e a assunção dos riscos da atividade pelo empresário}

Na lição de Giuseppe Ferri, a oferta de bens e serviços no mercado não é resultado de uma atividade acidental e improvisada, mas de uma atividade especializada e profissional, exercida por meio de um organismo econômico denominado empresa ${ }^{3}$. Ainda segundo esse autor, a empresa pode ser traduzida na organização de fatores pessoais e reais, que visa a determinado resultado econômico e é estruturada em função de idéias e objetivos de uma pessoa conhecida como empresário ${ }^{4}$.

Rubens Requião, analisando o ensinamento de Giuseppe Ferri, resume a relação entre os conceitos de empresa e empresário ${ }^{5}$ e afirma que, sob perspectiva jurídica, a empresa nada mais é do que a atividade desempenhada pelo empresário ${ }^{6}$.

Barros Leães resume o conceito de empresa sob o ponto de vista estritamente prático, quando comparado à análise dos doutrinadores citados acima. Para ele, a empresa

\footnotetext{
${ }^{3}$ Ainda que o escopo do presente trabalho esteja intimamente atrelado aos institutos do comércio, decidiu-se não incluir a sua evolução histórica no presente trabalho, dando ênfase à atual figura da empresa e às formas de remuneração do capital investido, objeto propriamente dito desta dissertação. Para maiores detalhes sobre a historicidade do comércio e dos seus institutos, vide LAMY FILHO, Alfredo. Temas de S.A.: exposições e pareceres. Rio de Janeiro: Renovar, 2007. p. 2-23, DINIZ, Gustavo Saad. Subcapitalização societária. 2007. Tese (Doutorado), Faculdade de Direito, Universidade de São Paulo, São Paulo, 2007. p. 13-51, VERÇOSA, Haroldo Malheiros Duclerc. Curso de direito comercial. São Paulo: Malheiros Ed., 2004. v. 1, p. 29-75, e ASCARELLI, Tullio. Origem do direito comercial (Tradução de Fábio Konder Comparato do Capítulo I do Corso di Diritto Commerciale - Introduzione e Teoria dell' Impresa. $3^{\text {a }}$ Ed. Milão: Guiffrè, 1962). Revista de Direito Mercantil, Industrial, Econômico e Financeiro São Paulo, v. 103, p. 87-100, 1996.

${ }^{4}$ FERRI, Giuseppe. Manuale di diritto commerciale. 4. ed. Torino: UnioneTipografico-Editrice Torinese, 1976. p. 33-34.

${ }^{5}$ Para uma detalhada análise do conceito de empresário, vide ASCARELLI, Tullio. O empresário. Tradução de Fábio Konder Comparato do Corso di Diritto Commerciale - Introduzione e Teoria dell' Impresa. $3^{a}$ ed. Milão: Guiffrè, 1962, p. 145-160. Revista de direito Mercantil, Industrial, Econômico e Financeiro, São Paulo, v. 109, p. 183-189, 1998.

${ }^{6}$ REQUIÃO, Rubens. Curso de direito comercial. 27. ed. São Paulo: Saraiva, 2007. v. 1, p. 51.
} 
é o mecanismo por meio do qual "a produção de bens e serviços, com objetivo lucrativo, é feita, na economia de mercado"7.

Com base em definição do conceito de empresa semelhante àquele proposto por Giuseppe Ferri, Francesco Ferrara Jr. aponta três principais características das empresas: (i) exercício de atividade econômica que visa à produção e comercialização ${ }^{8}$ de bens e serviços; (ii) atividade essa devidamente organizada; e (iii) exercida de forma profissional ${ }^{9}$.

A empresa pode ser definida, portanto, como uma espécie de unidade de produção cujo objetivo é desempenhado pelo empresário por meio da junção dos fatores capital e trabalho. Em outras palavras, é o conjunto de recursos organizados em função do exercício de determinada atividade produtiva vislumbrada pelo empresário.

Traduzindo esses conceitos, o artigo 2.082 do Código Civil Italiano define o empresário como aquele que exerce profissionalmente uma atividade econômica organizada que visa à produção e comercialização de bens e serviços ${ }^{10}$. Seguindo a mesma linha do Regramento Italiano, o Código Civil Brasileiro - Lei $\mathrm{n}^{\circ}$ 10.406/02, em seu artigo 966, determina que o empresário é aquele que exerce profissionalmente uma determinada atividade econômica organizada, que visa à produção ou circulação de bens e serviços ${ }^{11}$.

Aprofundando o estudo sobre a figura do empresário, Giuseppe Ferri aponta dois elementos essenciais que servem à delimitação do seu conceito: a iniciativa e o risco ${ }^{12}$. A iniciativa é o poder imputado ao empresário, que permite que esse determine a estrutura da empresa para o exercício da atividade proposta. O risco, por sua vez, consiste na conseqüente assunção, pelo empresário, de todas as conseqüências inerentes à organização da empresa, sejam elas favoráveis ou desfavoráveis. Ora, se ao empresário é concedido o direito de organizar a estrutura empresarial, nada mais lógico que seja também imputado a ele o ônus e o bônus resultantes dessa atividade. Os elementos apontados por Giuseppe Ferri são, portanto, indissociáveis.

\footnotetext{
${ }^{7}$ LEÃES, Luiz Gastão Paes de Barros. Do direito do acionista ao dividendo. São Paulo: Obelisco Ed., 1969. p. 11.

${ }^{8}$ Essa característica da empresa a diferencia das unidades de produção existentes até a Revolução Industrial. Regra geral, na Antiguidade e na Idade Média, o principal objetivo das unidades produtoras era o consumo pelos membros do grupo, de forma que apenas o excedente era objeto de troca.

${ }^{9}$ FERRARA JR., Francesco. Gli impreditori e le società. Milano: Giuffrè, 1975. p. 32.

10"Art. 2.082. Ė imprenditore chi esercita professionalmente un'attività economica organizzata al fine della produzione o dello scambio di beni o di servizi."

11“"Artigo 966. Considera-se empresário quem exerce profissionalmente atividade econômica organizada para a produção ou a circulação de bens ou de serviços."

${ }^{12}$ FERRI, Giuseppe. op. cit., p. 35.
} 
O elemento risco, próprio do conceito de empresário, foi muito bem destacado por Bulhões Pedreira ${ }^{13}$, co-autor do projeto de lei convertido na atual Lei das Sociedades Anônimas - Lei $n^{\circ}$ 6.404/76, que, ao apontar as três principais características das empresas, mencionou a assunção integral dos riscos da atividade pelo empresário.

Íntima e diretamente relacionado aos conceitos de empresa e empresário, está o conceito de sociedade empresária. Conforme bem definido por Rubens Requião, a sociedade empresária é o sujeito de direito, enquanto a empresa é o seu objeto ${ }^{14}$. Ao ser constituída nos termos da legislação vigente, a sociedade empresária adquire personalidade jurídica, passando a exercitar a atividade produtiva proposta. A sociedade é, portanto, nos termos descritos acima, o próprio empresário, existente, no entanto, sob forma coletiva ${ }^{15}$. Nesse sentido, Giuseppe Ferri afirma que a sociedade é uma forma de exercício coletivo da empresa $^{16}$. Para a sociedade empresária, portanto, valem todos os comentários realizados acima em relação aos empresários, inclusive quanto à assunção dos riscos da atividade de empresa.

Fábio Ulhôa Coelho aponta importante confusão existente em relação aos conceitos de empresa e empresário. Para ele, a confusão decorre do fato de o Direito Positivo Brasileiro, ao tratar do sujeito da atividade empresarial, fazer constante alusão a características próprias das pessoas físicas, de forma a permitir que o leitor entenda que a figura do empresário é incompatível com as pessoas jurídicas. A confusão conceitual é agravada pela usual utilização do termo empresa e empresário para designar a pessoa jurídica empresária e os seus sócios, respectivamente. Acertadamente, esse autor esclarece a confusão ao afirmar que "a empresa pode ser explorada por uma pessoa física ou jurídica. No primeiro caso, o exercente da atividade econômica se chama empresário individual; no segundo, sociedade empresária. Como é pessoa jurídica que explora a atividade empresarial, não é correto chamar de 'empresário' o sócio da sociedade empresária." 17

\footnotetext{
${ }^{13}$ PEDREIRA, José Luiz Bulhões. Finanças e demonstrações financeiras da companhia. Rio de Janeiro: Forense, 1989. p. 269-272.

${ }^{14}$ REQUIÃ̃O, Rubens. op. cit., v. 1, p. 60.

${ }^{15}$ Nesse mesmo sentido, vide COELHO, Fábio Ulhôa. Curso de direito comercial. 11. ed. São Paulo: Saraiva, 2007. v. 1, p. 63, e DINIZ, Gustavo Saad. op. cit., p. 55. Gustavo Saad Diniz expressamente afirma que "o empresário pode atuar individualmente ou então por meio da constituição de pessoa jurídica. Da segunda forma, adota-se um tipo societário e transfere-se para um patrimônio separado (da personalidade jurídica criada) os riscos da empresa."

16“"la società è nel sistema del codice una forma di esercizio colletivo dell'impresa" (FERRI, Giuseppe. op. cit., p. 208).

${ }^{17}$ COELHO, Fábio Ulhôa. op. cit., v. 1, p. 63-64.
} 
Seguindo esse conceito de sociedade empresária, os artigos 981 e 982 do Código Civil Brasileiro - Lei $\mathrm{n}^{\mathrm{o}} 10.406 / 02^{18}$ - a definem como o grupo de pessoas que firmam contrato, segundo o qual reciprocamente se obrigam a contribuir, com bens ou serviços, para o exercício de atividade econômica própria de empresário ${ }^{19}$ e a partilhar os resultados auferidos.

Da redação desses artigos surge um novo aspecto do conceito de sociedade empresária: o objetivo lucrativo ${ }^{20}$.

O objetivo lucrativo, segundo De Plácido e Silva, decorre da própria noção de sociedade comercial ${ }^{21}$, que, além do mero intuito de comunhão de interesses inerente às sociedades (affectio societatis), deve necessariamente ter intuito de lucro ou especulação ${ }^{22}$ $\operatorname{comum}^{23}$. Em outras palavras, o intuito de comunhão de interesses nesse tipo societário deve ter natureza mercantil e, portanto, lucrativa. Nos dizeres de José Edwaldo Tavares Borba, "o fim lucrativo é a essência da sociedade mercantil, a qual se destina a produzir lucro, para distribuição aos que participam de seu capital social",24.

O objetivo lucrativo também está expressamente previsto na Lei das Sociedades Anônimas - Lei $n^{\circ}$ 6.404/76, cujo artigo $2^{\circ}$ prevê que as empresas de fim lucrativo são o

\footnotetext{
18“"Artigo 981. Celebram contrato de sociedade as pessoas que reciprocamente se obrigam a contribuir, com bens ou serviços, para o exercício de atividade econômica e a partilha, entre si, dos resultados.

Parágrafo único. A atividade pode restringir-se à realização de um ou mais negócios determinados.

Artigo 982. Salvo as exceções expressas, considera-se empresária a sociedade que tem por objeto o exercício de atividade própria de empresário sujeito a registro (art. 967); e, simples, as demais.

Parágrafo único. Independentemente de seu objeto, considera-se empresária a sociedade por ações; e, simples, a cooperativa."

${ }^{19}$ Como atividade própria de empresário, entende-se atividade econômica organizada para a produção ou circulação de bens e serviços (Artigo 966 do Código Civil Brasileiro - Lei no 10.406, de 10 de janeiro de 2002).

${ }^{20}$ Fran Martins aponta o objetivo lucrativo como qualidade do comerciante/empresário em MARTINS, Fran. Curso de direito comercial. 1. ed. Rio de Janeiro: Ed. Forense, 1993. p. 84-85.

${ }^{21}$ Uma antiga classificação das sociedades prevê sua distribuição em dois diferentes grupos: sociedades comerciais e sociedades civis. Regra geral, a diferença entre essas espécies de sociedades pode ser identificada em função da natureza do seu objeto social. Diferentemente das sociedades civis, as sociedades comerciais devem necessariamente ter finalidade econômica, como é o caso das sociedades anônimas e das sociedades de responsabilidade limitada. Por essa razão, ainda que os comentários de De Plácido e Silva não tratem de sociedades empresárias (classificação proposta por legislação mais recente), mas de sociedades comerciais, entendemos que esses comentários são aplicáveis à análise proposta. Para maiores detalhes sobre a classificação das sociedades como sociedades civis ou comerciais, vide MIRANDA, Francisco Cavalcanti Pontes de. Tratado de direito privado. 3. ed. São Paulo: Ed. Revista dos Tribunais, 1984. v. 49, p. 26-27.

${ }^{22} \mathrm{O}$ verbo "especular" pode ser entendido como a ação de "meter-se em operações financeiras visando apenas lucros". (FERREIRA, Aurélio Buarque de Holanda. Miniaurélio século XXI: o minidicionário da língua portuguesa. 4. ed. Rio de Janeiro: Nova Fronteira, 2000).

${ }^{23}$ SILVA, De Plácido e. Noções práticas de direito comercial. 12. ed. Rio de Janeiro: Forense, 1965. v. 1, p. 142-143.

${ }^{24}$ BORBA, José Edwaldo Tavares. Direito societário. 2. ed. Rio de Janeiro: Freitas Bastos, 1995. p. 34.
} 
objeto social desse tipo societário ${ }^{25}$, e no já citado artigo 2.082 do Código Civil Italiano. Conforme ensina Tullio Ascarelli, o adjetivo "econômica", utilizado na redação desse artigo 2.082 para referir-se à atividade da empresa, deve ser entendido como a qualidade de gerar riqueza ${ }^{26}$.

Sobre o objetivo lucrativo das empresas, previsto no artigo 2.082 Código Civil Italiano, Marcos Paulo de Almeida Salles afirma que aquele código representa um marco na história do Direito Comercial, tendo em vista que transpõe "a tradição do ato de comércio, ou da mercancia, para a atividade da empresa, ou empresarialidade". Esse autor define a publicação do Código Civil Italiano como o início da idéia de conjugação de fatores de produção com objetivo lucrativo, voltada não apenas para a remuneração do capital, mas de todos os demais fatores de produção ${ }^{27}$.

O requisito do fim lucrativo pode, segundo Barros Leães, ser analisado sob duas diferentes perspectivas: (i) objetivo lucrativo como uma das características das sociedades (perspectiva objetiva já analisada no presente trabalho); (ii) obrigação de divisão, entre os sócios, dos lucros auferidos pela sociedade (perspectiva subjetiva) ${ }^{28}$.

Essa perspectiva subjetiva da necessária finalidade lucrativa de uma sociedade pode ser identificada no próprio conceito de sociedade empresária encontrado na parte final do caput do já mencionado artigo 981 do Código Civil Brasileiro - Lei $\mathrm{n}^{\circ}$ $10.406 / 02^{29}$. Segundo esse dispositivo, as partes de um contrato de sociedade, i.e., os sócios, visam, entre outros objetivos, à partilha dos resultados entre si.

Da mesma forma, o conceito de sociedade encontrado no Direito Positivo Italiano, ao qual o conceito previsto na Legislação Brasileira muito se assemelha, também traduz essa perspectiva subjetiva da finalidade lucrativa. Segundo o artigo 2.247 do Código Civil Italiano, o contrato de sociedade é aquele no qual duas ou mais pessoas conferem bens ou serviços para o exercício comum de uma atividade econômica que visa à distribuição do

\footnotetext{
25،Artigo $\mathbf{2}^{\mathbf{0}}$. Pode ser objeto da companhia qualquer empresa de fim lucrativo, não contrário à lei, à ordem pública e aos bons costumes". A redação desse artigo também confirma a definição de empresa como atividade exercida pelo empresário, conforme demonstrado anteriormente no presente trabalho.

${ }^{26}$ ASCARELLI, Tullio. A atividade do empresário (Tradução de Erasmo Valladão A. e N. França do Capítulo VII do Corso di Diritto Commerciale - Introduzione e Teoria dell' Impresa. $3^{\text {a }}$ Ed. Milão: Guiffrè, 1962, p. 161-185). Revista de direito Mercantil, Industrial, Econômico e Financeiro, São Paulo, v. 132, p. 203-205, 2003.

${ }^{27}$ SALLES, Marcos Paulo de Almeida. Política de Dividendos - função econômica do dividendo, Revista de Direito Bancário do Mercado de Capitais e da Arbitragem, São Paulo, n. 14, p. 79, 2001.

${ }^{28}$ LEÃES, Luiz Gastão Paes de Barros. op. cit., p. 255.

${ }^{29}$ Vide nota de rodapé $\mathrm{n}^{\circ} 16$.
} 
lucro $^{30}$. A parte final desse artigo é clara, portanto, quanto ao objetivo dos sócios ao firmarem um contrato de sociedade: a divisão dos lucros a serem auferidos pela sociedade ${ }^{31}$.

Também o artigo 109, inciso I, da Lei das Sociedades Anônimas - Lei no 6.404/76 - é claro, ao resguardar o direito do acionista ao dividendo, prevendo que nem o estatuto social nem a assembléia geral poderão privá-lo do seu direito de participação nos lucros sociais. O intuito de lucro é resguardado e assegurado ao acionista pelo artigo 109 dessa lei, sendo impossível vislumbrar a prática da atividade da empresa sem objetivo lucrativo, seja por parte da própria sociedade ou de seus sócios.

Note-se que a assunção dos riscos da atividade pelo empresário e, portanto, pela sociedade, possui implicações diretas na concretização do seu objetivo lucrativo. Ao assumir os riscos da atividade desempenhada, a sociedade assume também as conseqüências imediatas de operações deficitárias da atividade de empresa. Em outras palavras, ainda que a lucratividade seja o objetivo principal das sociedades e, conseqüentemente, dos sócios (na lição de Barros Leães, perspectiva subjetiva), nem sempre é verificada a sua efetivação, e os efeitos imediatos de uma sociedade com prejuízos registrados em seu balanço são sentidos pelos sócios, na medida em que não haverá distribuição de lucros.

No caso de falência de uma sociedade, um cenário ainda mais dramático, portanto, a não-concretização do objetivo lucrativo representa não apenas a falta de recebimento de lucros durante o período ativo da sociedade, mas a impossibilidade de receber de volta o capital investido na sociedade liquidada.

Nesse sentido, vale mencionar a idéia de risco constante da seara econômica. Para os estudiosos dessa área, como Shannon Pratt ${ }^{32}$ e Aswath Damodaran ${ }^{33}$, o risco pode ser entendido como o grau de certeza ou incerteza da concretização do retorno esperado. É

\footnotetext{
30“Art. 2.247. Con il contratto di società due o più persone conferiscono beni o servizi per l'esercizio in comune di un'attività economica allo scopo di dividerne gli utili". Ainda sobre esse assunto, Francesco Ferrara Jr. fala, em sua obra (Gli impreditori e le società, cit., p. 236-240), sobre a regra prevista no artigo 2.265, do Código Civil Italiano, segundo a qual é nulo o acordo em que um ou mais sócios estão excluídos da participação dos lucros (“Art. 2.265. È nullo il patto con il quale uno o più soci sono esclusi da ogni partecipazione agli utili o alle perdite").

${ }^{31}$ Sobre o direito dos sócios ao lucro no Direito Italiano, vide FERRI, Giuseppe. Le societá - Trattato di diritto civile. Torino: UnioneTipografico-Editrice Torinese, 1971. n. 3, v. 10, p. 153-159.

${ }^{32}$ Detalhes sobre a posição de Pratt sobre o assunto podem ser encontrados em PRATT, Shannon Pease, D.B.A. Relationship between risk and rate of return for common stocks. Indiana University, 1967.

${ }^{33}$ Para detalhes sobre o tema, veja DAMODARAN, Aswath. Value and risk: beyond betas. Financial Analysts Journal, Charlottesville, v. 61, n. 2, p. 38-44, Mar./Apr. 2005.
} 
inversa a relação entre risco e certeza quanto à concretização da expectativa de lucratividade. Em outras palavras, o risco aumenta em função da diminuição da certeza do investidor quanto ao valor e momento do retorno ${ }^{34}$.

\section{O financiamento das sociedades empresárias como pressuposto para o desempenho}

\section{das suas atividades: as fontes de origem do capital aplicado e a natureza das correspondentes remunerações}

O funcionamento da sociedade depende da formação e manutenção de capital $^{35}$ em seu patrimônio, i.e., da existência de capital aplicado, conforme terminologia utilizada por Bulhões Pedreira. Sobre esse assunto e para os fins do presente trabalho, importa destacar a figura dos sistemas de capitalização e financiamento das sociedades.

Capitalização, segundo Bulhões Pedreira ${ }^{36}$ e Heleno Taveira Tôrres ${ }^{37}$, é o ato ou efeito de constituir capital financeiro no patrimônio da sociedade empresária. Por sua vez, financiamento é a ação ou efeito de financiar, conferindo o capital necessário a um determinado empreendimento ${ }^{38}$. Em outras palavras, o financiamento de uma empresa é o ato de transferir ao patrimônio da sociedade empresária os recursos necessários para a sua instalação e para a realização e aprimoramento de suas atividades, qual seja, a produção de bens e serviços.

Ainda que pareçam conceitos idênticos, uma sutil particularidade da capitalização a diferencia do financiamento: a capitalização da sociedade empresária pressupõe o seu financiamento. Regra geral, o capital conferido ao patrimônio de determinada sociedade

\footnotetext{
${ }^{34}$ Sobre a relação entre risco e retorno na seara econômica, veja GARRÁN, Felipe Turbuk. Metodologias em uso no Brasil para a determinação do custo de capital próprio para avaliação de ativos por fluxo de caixa descontado. 2006. Dissertação (Mestrado) - Faculdade de Economia - FEA, Universidade de São Paulo, São Paulo, 2006. p. 31-32.

${ }^{35}$ Capital sob acepção financeira e não jurídica. Sobre a diferenciação entre os diferentes conceitos de capital, veja DINIZ, Gustavo Saad. op. cit., p. 85 e ss, PENTEADO, Mauro Rodrigues. Aumentos de capital das sociedades anônimas. São Paulo: Saraiva, 1988. p. 32-34, e LEÃES, Luiz Gastão Paes de Barros. op. cit., p. 77-81.

${ }^{36}$ PEDREIRA, José Luiz Bulhões. op. cit., p. 318.

${ }^{37}$ TÔRRES, Heleno Taveira. Direito tributário internacional: planejamento tributário e operações transnacionais. São Paulo: Ed. Revista dos Tribunais, 2001. p. 510, e Id. Juros sobre capital próprio autonomia privada nos investimentos societários e suas implicações em matéria tributária. In: TÔRRES, Heleno Taveira. (Org.). Direito tributário internacional aplicado. São Paulo: Quartier Latin, 2007. v. 4, p. 355.

${ }^{38}$ FERREIRA, Aurélio Buarque de Holanda. Novo dicionário da língua portuguesa. 2. ed. Rio de Janeiro: Nova Fronteira, 1986. p. 781.
} 
empresária tem sua origem em outros patrimônios e, portanto, deve ser transferido ao patrimônio da sociedade empresária para que a capitalização dessa sociedade seja efetiva. A transferência de patrimônio necessária à capitalização da sociedade empresária é a ação ou procedimento entendido como financiamento. São, portanto, conceitos indissociáveis.

Vale ressaltar que existe a possibilidade de o financiamento de uma sociedade não se dar por meio da transferência entre patrimônios, mas mediante o acúmulo de riquezas no próprio patrimônio da sociedade empresária. A esse método de financiamento se dá o nome de autofinanciamento, o qual será analisado no item 2.1, que trata da origem do capital aplicado.

O financiamento de uma sociedade pode se dar em uma ou mais etapas. $\mathrm{O}$ primeiro e imprescindível financiamento de uma sociedade ocorre no momento da sua constituição, quando a sua capitalização é necessária para a sua organização e aquisição dos recursos necessários ao desenvolvimento das atividades propostas. Após a constituição da sociedade e o regular desempenho das suas atividades, existe a possibilidade de serem necessários financiamentos complementares para o exercício das operações empresariais. Esse último tipo de financiamento é denominado, por Barros Leães, como financiamento de expansão ${ }^{39}$.

Para a definição de financiamento ${ }^{40}$ de uma empresa, é irrelevante a forma como o esse financiamento é realizado, ou seja, se é concedido a longo ou a curto prazo, por prazo determinado ou indeterminado, de forma temporária ou permanente etc. Verificada a concessão de recursos para a realização do objeto social da empresa, estará, inevitavelmente, caracterizado o financiamento.

Entretanto, uma característica especial dos financiamentos das empresas é de extrema relevância para este estudo: a origem dos recursos financiados. No próximo item, serão analisadas em detalhe as diferentes fontes de financiamento das sociedades.

\footnotetext{
${ }^{39}$ LEÃES, Luiz Gastão Paes de Barros. op. cit., p. 13.

${ }^{40}$ Para os fins do presente trabalho, optou-se por utilizar o termo financiamento de forma genérica, tendo em vista que o momento de realização do financiamento da sociedade não é relevante para o estudo proposto.
} 


\subsection{A origem do capital aplicado: fontes de capital próprio e de terceiros. As vantagens e desvantagens do financiamento do capital aplicado mediante capital próprio e capital de terceiros}

Segundo Bulhões Pedreira, quanto à sua origem, o capital aplicado pode ser classificado de duas diferentes formas ${ }^{41}$. A primeira delas refere-se à localização da fonte de financiamento. Segundo esse critério, o capital aplicado é classificado, em função da localização da fonte de capital em relação à sociedade financiada, como capital aplicado originado de outros patrimônios (fonte externa ${ }^{42}$ ) ou acumulado no próprio patrimônio (fonte interna).

Conforme mencionado, o financiamento do capital aplicado é a transferência de recursos ao patrimônio da sociedade para possibilitar o desenvolvimento da atividade empresarial. Nesse sentido, a classificação do capital aplicado segundo esse critério decorre da localização da fonte de origem do fluxo de recursos utilizado para o financiamento da sociedade.

Ainda que a regra seja o financiamento em função do fluxo de recursos entre patrimônios diversos (fontes externas de financiamento, portanto ${ }^{43}$, existe a possibilidade de este ser decorrente do autofinanciamento da sociedade. Nesse caso, a capitalização da sociedade tem sua origem no acúmulo de recursos no seu próprio patrimônio, i.e., tem sua origem em fonte interna de recursos.

O autofinanciamento só é possível após a constituição da sociedade, com o regular exercício de suas atividades, uma vez que este depende da geração de renda pela sociedade. A possibilidade de realização de autofinanciamento no momento de constituição da sociedade é, portanto, incompatível com o próprio conceito de autofinanciamento.

O segundo critério de classificação do capital aplicado em função da sua origem refere-se à natureza da fonte dos recursos utilizados no seu financiamento. Com base nesse critério, o capital aplicado pode ser originado de capital próprio ou de terceiros. Sobre a

\footnotetext{
${ }^{41}$ PEDREIRA, José Luiz Bulhões. op. cit., p. 202 e ss.

${ }^{42}$ Para definição detalhada do conceito de fonte externa, veja RIBEIRO, Antônio Carlos Silva. Aspectos tributários da subcapitalização no sistema jurídico alemão e brasileiro. Revista de Direito Tributário Internacional, São Paulo, ano 3, n. 9, p. 24-26, 2008.

${ }^{43}$ Especialmente em relação à definição do conceito de financiamento, vide item 2 do presente trabalho.
} 
diferença entre o capital próprio e o capital de terceiros, Bulhões Pedreira ${ }^{44}$ ensina que " $o$ capital aplicado no ativo que corresponde às obrigações do patrimônio pertence a terceiros, e somente a parte que excede do valor total dessas obrigações é de propriedade do titular do patrimônio". Em outras palavras, o capital aplicado pertencente a terceiros é aquele traduzido no passivo exigível da sociedade, enquanto o capital aplicado de propriedade do titular do patrimônio é aquele delimitado pelo patrimônio líquido.

Assim, para esse autor, a diferença entre o financiamento da sociedade por meio de capital próprio ou por meio de capital de terceiros consiste, basicamente, no surgimento ou não de obrigação de restituição do valor financiado. Segundo Barros Leães e Mauro Penteado, o capital de terceiros é também conhecido como capital-crédito, exatamente em virtude do nascimento de um crédito (registrado no passivo exigível da sociedade) do terceiro contra a sociedade financiada ${ }^{45}$.

O aumento de capital por sócios da sociedade e a capitalização dos lucros auferidos pela sociedade são, portanto, exemplos clássicos de financiamento da sociedade por meio de capital próprio ${ }^{46}$. Como exemplo de forma típica de financiamento mediante capital de terceiros, podemos citar a contratação de empréstimos ${ }^{47}$.

É importante notar que o passível exigível (valor negativo) é apenas a forma de constatação do capital aplicado pertencente a terceiros. O capital aplicado de propriedade de terceiros encontra-se, na realidade, no ativo da sociedade ${ }^{48}$. Em outras palavras, os recursos efetivamente transferidos à sociedade por meio de financiamento com capital de terceiros devem ser adicionados ao ativo da sociedade, passando a fazer parte do seu patrimônio e, conseqüentemente, perdendo sua identidade. Entretanto, em contrapartida, nasce a obrigação de devolução ou mesmo de remuneração desse capital, obrigação esta registrada no passivo exigível da mesma sociedade. Assim, diante da impossibilidade de se

\footnotetext{
${ }^{44}$ PEDREIRA, José Luiz Bulhões. op. cit., p. 367-386.

${ }^{45}$ PENTEADO, Mauro Rodrigues. op. cit., p. 33, e LEÃES, Luiz Gastão Paes de Barros. op. cit., p. 79.

${ }^{46}$ Quanto à possível classificação do capital social como dívida da sociedade com seus sócios, entendemos que, diferentemente da idéia de passivo exigível, esse conceito está atrelado, na realidade, ao direito de os sócios receberem parcela do patrimônio da sociedade em alguns casos específicos previstos na lei. São eles: (i) recebimento de parcela do acervo social da sociedade, se existente, em caso de liquidação, (ii) direito de retirada da sociedade, nos casos previstos em lei, conforme regramentos específicos destinados às sociedades anônimas, sociedades limitadas ou outros tipos societários, ou (iii) recebimento de parcela proporcional do capital social reduzido. Nos três casos mencionados, ainda que efetivamente existente o direito dos sócios, são direitos exigíveis apenas mediante a concretização dos eventos correspondentes. Sobre esse assunto, veja VIVANTE, Cesare. Trattato di diritto commerciale: le società commerciali. 5. ed. Milano: Francesco Vallardi, 1929. v. 2, p. 378-379.

${ }^{47}$ Esses exemplos serão adotados como base da análise proposta pelo presente trabalho.

${ }^{48}$ Ao afirmar que o capital de terceiros se encontra no ativo da sociedade, não se pretende concluir que àquele capital se identificam bens específicos do ativo da sociedade, mas apenas o seu valor financeiro.
} 
identificar no ativo da sociedade o valor exato do capital de terceiros transferido em seu benefício, é o passivo exigível que permite a constatação desse valor.

Existe a possibilidade de o passivo exigível não se valer a essa tarefa, hipótese na qual o patrimônio líquido da sociedade será negativo, i.e., o valor do ativo da sociedade, formado por capital próprio e de terceiros, é insuficiente para cobrir o valor do passível exigível $^{49}$. Partindo da premissa de que o capital de terceiros está, na realidade, registrado no ativo da sociedade, na hipótese em que o patrimônio líquido é negativo, o valor registrado no passivo exigível da sociedade não traduz o valor efetivo do capital de terceiros registrado no seu ativo, mas apenas o valor de parcela dos financiamentos realizados por meio dessas fontes ${ }^{50}$.

Da mesma forma, o patrimônio líquido apenas se presta a identificar o valor do capital próprio registrado no ativo da sociedade. Se o patrimônio líquido é a diferença entre ativos e passivos da sociedade e o ativo da sociedade é formado tanto por capital de terceiros como por capital próprio, o patrimônio líquido pode ser utilizado para constatar o volume de capital próprio aplicado na sociedade ${ }^{51}$.

Ainda que os critérios de classificação expostos acima sejam tratados separadamente por Bulhões Pedreira (o primeiro como localização da fonte de origem do financiamento e o segundo como a natureza da fonte de recursos), acreditamos que estes devem ser aplicados de forma conjunta, uma vez que, no autofinanciamento (fonte interna), os recursos têm sua origem necessariamente no capital próprio. Assim, sugerimos que a classificação como capital próprio ou de terceiros seja adotada como espécie do gênero denominado fonte externa de financiamento (capital aplicado tem origem em outros patrimônios) e o autofinanciamento (fonte interna) seja tratado como um novo gênero, sem qualquer distinção de espécies em função da qualidade do capital aplicado como capital de terceiros ou capital próprio.

Independentemente da estrutura de classificação adotada, para os fins do presente trabalho, será utilizada apenas a diferenciação entre capital próprio e de terceiros. Isso porque o seu objeto está, em sua essência, diretamente relacionado à análise da

\footnotetext{
${ }^{49}$ PEDREIRA, José Luiz Bulhões. op. cit., p. 209-210.

${ }^{50} \mathrm{O}$ passivo exigível não pode ser utilizado para a constatação do valor total dos financiamentos realizados por meio de capital de terceiros, uma vez que parte desses financiamentos pode ter sido liquidada no passado e, portanto, não deverá constar da conta do passivo exigível da sociedade.

${ }^{51}$ PEDREIRA, José Luiz Bulhões. op. cit., p. 210-211.
} 
remuneração de sócios ${ }^{52}$ e terceiros ligados à sociedade. Conforme será demonstrado oportunamente, a natureza da fonte dos recursos (capital próprio ou de terceiros) utilizados no financiamento será mais relevante à análise proposta do que a localização da fonte dos recursos em relação à sociedade (fonte interna ou externa).

\subsubsection{A opção pelo financiamento da sociedade com utilização de capital próprio ou de terceiros: vantagens e desvantagens}

Sob o ponto de vista histórico, a despeito de o capital próprio ter sido a fonte originária de financiamento das sociedades empresárias, o financiamento por meio de capital de terceiros surgiu como forma de possibilitar o crescimento das atividades mercantis. Nas palavras de Gustavo Saad Diniz, sob perspectiva econômica, as sociedades surgiram como instrumento facilitador do tráfico mercantil, viabilizando a obtenção de melhores resultados ${ }^{53}$. O surgimento do capital de terceiros como forma de financiamento das sociedades decorreu de uma nova necessidade de expansão das atividades em virtude da aceleração dos meios de circulação.

Dentre outras atribuições dos sócios e administradores das sociedades modernas, encontra-se a decisão quanto à fonte de recurso a ser utilizada no financiamento da sociedade: capital próprio ou capital de terceiros ${ }^{54}$. O financiamento das sociedades mediante a utilização de cada uma dessas fontes de recursos possui vantagens e desvantagens, que devem ser levadas em consideração no momento da decisão quanto à estrutura de capital da sociedade, com a análise macro dos cenários político e econômico vigentes.

O financiamento com origem no capital próprio possui, regra geral, duas principais características: a indeterminação do prazo de concessão do financiamento e a existência de remuneração atrelada aos resultados da empresa investida. Esse tipo de

\footnotetext{
${ }^{52}$ Para os fins deste trabalho, não importa a diferenciação entre o conceito de sócios e acionistas, tampouco a diferenciação entre os conceitos de distribuição de dividendos e de lucros. Assim, preferiu-se adotar o termo sócios de forma generalizada e ambos os termos, dividendos ou lucros, para representar a remuneração comum dos sócios, sem qualquer distinção em função das particularidades atinentes a cada um destes conceitos.

${ }^{53}$ DINIZ, Gustavo Saad. op. cit., p. 49.

${ }^{54}$ Sobre a estrutura de capital das sociedades brasileiras, veja VALLE, Mauricio Ribeiro do. Estrutura de capital de empresas brasileiras num ambiente de altas taxas de juros e na presença de fontes diferenciadas de financiamento. 2008. Tese (livre-docência) - Faculdade de Economia - FEA, Universidade de São Paulo, São Paulo, 2008.
} 
financiamento pode se dar no momento inicial de constituição da sociedade, ou mesmo em momento superveniente, por meio de aumento de capital social ou retenção autorizada de lucros passíveis de distribuição ${ }^{55}$.

Diferentemente, os financiamentos realizados por meio de capital de terceiros são concedidos, regra geral, por prazo e remuneração determinados no momento da sua concessão à sociedade beneficiária ${ }^{56}$. Em sua maioria, são financiamentos realizados após a constituição da sociedade, destinados a assegurar o incremento ou manutenção das suas atividades.

Bulhões Pedreira ${ }^{57}$ lista as seguintes vantagens de se financiar o capital aplicado de determinada sociedade com volume de capital próprio proporcionalmente mais elevado do que aquele de capital de terceiros:

(i) maior estabilidade financeira, conseguida em virtude do reduzido valor dos passivos exigíveis da sociedade. A liberdade e conseqüente estabilidade financeira da sociedade decorrem da maior disponibilidade de caixa para assegurar o desenvolvimento das atividades empresariais e o cumprimento das demais obrigações assumidas em virtude do desenvolvimento dessas mesmas atividades;

(ii) preservação da capacidade futura de endividamento. Na economia de mercado, o limite máximo de endividamento de uma sociedade está diretamente relacionado à proporção entre capital de terceiros e capital próprio aplicado. Essa relação entre passivo exigível e patrimônio líquido ${ }^{58}$ (ver item 2.1 acima) é um dos fatores utilizados para a realização de análises de risco de crédito, tendo em vista estar diretamente ligada ao fator de liquidez e solvência dos ativos da sociedade;

(iii) maior eficiência administrativa, decorrente do reduzido volume de passivo para ser administrado, implicando a concentração dos esforços administrativos no desempenho das atividades negociais.

\footnotetext{
${ }^{55}$ LEÃES, Luiz Gastão Paes de Barros. op. cit., p. 12.

${ }^{56}$ Id. Ibid., p. 12.

${ }^{57}$ PEDREIRA, José Luiz Bulhões. op. cit., p. 368 e ss.

${ }^{58} \mathrm{Ou}$ debt/equity ratio, jargão utilizado no mercado financeiro (GASTINEAUS, Gary L.; KRITZMAN, Mark P. Dicionário de administração e fisco financeiro. São Paulo: Ed. BM\&F, 1999). Sobre os diferentes índices utilizados para a identificação da estrutura de capital das sociedades, veja FURUTA, Fernanda. Estudo da consolidação proporcional nas empresas que atuam no mercado brasileiro. 2005. Dissertação (Mestrado) - Faculdade de Economia - FEA, Universidade de São Paulo, São Paulo, 2005. p. 98-100.
} 
A essas vantagens, Heleno Taveira Tôrres adiciona (i) a redução dos custos de financiamento mediante empréstimos de terceiros; (ii) a dedutibilidade dos juros como despesa financeira operacional ${ }^{59}$.

Em relação a essa última vantagem mencionada por Heleno Taveira Tôrres, vale ressaltar que esta não é uma vantagem exclusiva do financiamento mediante capital próprio, posto ser uma das principais vantagens do financiamento mediante capital de terceiros.

Adicionalmente à dedutibilidade das despesas financeiras, Bulhões Pedreira e Heleno Taveira Tôrres listam as seguintes vantagens dos financiamentos realizados por meio de capital de terceiros:

(i) preservação dos direitos de participação e não-interferência na direção e administração da sociedade. Em outras palavras, não há qualquer diluição dos direitos de voto e de dividendos dos então sócios. Isso porque os direitos de voto e de dividendos são essencialmente atrelados ao capital social da sociedade;

(ii) aumento da rentabilidade do capital próprio. A utilização de capital de terceiros para financiar as atividades da sociedade pode gerar o chamado “efeito de alavancagem da dívida". Sobre esse assunto, Modigliani e Miller propõem que o retorno ao acionista aumenta em função do endividamento da sociedade ${ }^{60}$;

(iii)maior disponibilidade de recursos para aplicação no financiamento. Independentemente da análise de risco de crédito atrelada à concessão de financiamentos mediante capital de terceiros, o volume de capital de terceiros disponível no mercado é infinitamente maior do que aquele dos sócios das empresas.

\footnotetext{
${ }^{59}$ TÔRRES, Heleno Taveira. Direito tributário internacional: planejamento tributário e operações transnacionais, cit., p. 513.

${ }^{60}$ Detalhes sobre essa proposição (Proposição II) de Modigliani e Miller em função do sistema legal brasileiro de remuneração de sócios pode ser encontrada em ABREU, Ari Ferreira de. op. cit., p. 38-50. Análise detalhada dessa Proposição de Modigliani e Miller pode ser encontrada em MARTINS, Vinícius Aversari. Interações entre estrutura de capital, valor da empresa e valor dos ativos. 2005. Tese (Doutorado) Faculdade de Economia - FEA, Universidade de São Paulo, São Paulo, 2005. p. 33-36, 50-51, e KAYO, Eduardo Kazuo. A estrutura de capital e o risco das empresas tangível e intangível-intensivas: uma contribuição ao estudo da valoração de empresas. 2002. Dissertação (Mestrado) - Faculdade de Economia FEA, Universidade de São Paulo, São Paulo, 2002. p. 27-29.
} 
Em contrapartida a essas vantagens, são também apontadas as desvantagens de se financiar uma sociedade mediante capital próprio ou de terceiros. Regra geral, as desvantagens de cada uma dessas espécies de financiamento podem ser opostas às vantagens do outro tipo analisado.

Enquanto o financiamento por meio de capital de terceiros possui como vantagens a preservação dos direitos de dividendo e voto, o aumento da rentabilidade do capital próprio e a maior disponibilidade de recursos, o financiamento por meio de capital próprio possui como desvantagens (i) a diluição dos direitos de participação dos sócios no processo decisório (incitando a instabilidade do controle da sociedade empresária; ressalvada a possibilidade de emissão de ações preferenciais) e no recebimento de dividendos; (ii) diminuição da taxa de rentabilidade do capital próprio; (iii) disponibilidade de recursos atrelada à figura dos sócios. Outra relevante desvantagem do financiamento mediante capital próprio consiste na previsão legal de indedutibilidade, para fins fiscais, da despesa com o pagamento de dividendos.

Quanto às desvantagens dos financiamentos por meio de capital de terceiros, podemos identificar aquelas que também possuem relação de contraposição com as vantagens de se realizar o financiamento mediante capital próprio. São elas: (i) redução da estabilidade financeira da sociedade; (ii) redução da capacidade futura de contrair dívidas; (iii) redução da eficiência administrativa; (iv) amplificação dos efeitos da diminuição de lucros ou reconhecimento de prejuízos em sociedades deficitárias; e (v) risco de perda de controle em virtude de possível iliquidez ou insolvência da sociedade ${ }^{61}$.

As vantagens e desvantagens dos financiamentos por meio de capital próprio e de terceiros serão detalhadamente analisadas no Capítulo II deste trabalho.

\subsection{Subcapitalização: a necessária proporcionalidade entre o volume de financiamento mediante capital próprio e capital de terceiros}

Conforme visto anteriormente no item 2.1 , o financiamento da sociedade é necessário ao regular desempenho das suas atividades e este pode se dar mediante capital

\footnotetext{
${ }^{61}$ Diante da extrema similaridade entre as desvantagens e vantagens analisadas neste item, limitamo-nos a citar aquelas.
} 
próprio e capital de terceiros, sendo o primeiro representado pelo patrimônio líquido e o segundo, pelo passivo exigível da sociedade.

Sob ponto de vista econômico-financeiro, a proporção entre o volume de capital de terceiros e capital próprio aplicado na sociedade tem impacto direto na definição da taxa de retorno do investimento. Isso porque, segundo o método comumente adotado, i.e., o Weighted Average Cost of Capital - WACC ${ }^{62}$, a taxa de retorno de um determinado investimento é definida em função da média ponderada entre os custos gerados pelo capital próprio e pelo capital de terceiros e suas respectivas participações na estrutura de capital da sociedade $^{63}$.

Sob o ponto de vista societário, ao decidir sobre a forma de financiamento da sociedade, se por meio de capital próprio ou de terceiros, é imprescindível resguardar uma das principais características das empresas: a necessidade de assunção, pelos sócios, dos riscos da atividade.

A eleição das fontes de financiamento deve sempre permitir que o capital próprio seja suficiente para evitar a socialização dos riscos da atividade com credores da sociedade e garantir que a utilização de capital de terceiros tenha como objetivo único a obtenção de melhores resultados para a sociedade, seja por meio de redução de custos ou incremento de atividades. $\mathrm{O}$ desrespeito a esse pressuposto do financiamento, causando a desproporcionalidade entre o volume de capital próprio e de terceiros aplicados na sociedade, denomina-se subcapitalização.

Gustavo Saad Diniz, citando Karsten Schmidt em sua Tese de Doutorado, define a subcapitalização como a falta ou insuficiência de capital próprio para a realização do objeto da sociedade, i.e., a incapacidade de a sociedade cumprir adequadamente a atividade econômica proposta ${ }^{64}$.

Para Mauro Penteado, os capitais próprios e de terceiros constantes da estrutura econômico-financeira da sociedade estão em permanente estado de tensão, uma vez que

\footnotetext{
${ }^{62}$ GARRÁN, Felipe Turbuk. op. cit., p. 13-14. É importante notar que, apesar de o Weighted Average Cost of Capital - WACC ser amplamente difundido entre os profissionais de finanças, não se pode descartar a existência de outros métodos para a definição da taxa de retorno de um determinado investimento.

${ }^{63}$ Ressaltamos que o cálculo da taxa de retorno do investimento, segundo o Weighted Average Cost of Capital - WACC, é complexo, criterioso e sujeito a variações, de forma que a definição proposta visa apenas resumir o seu princípio central.

${ }^{64}$ DINIZ, Gustavo Saad. op. cit., p. 59-60.
} 
deve ser mantido o equilíbrio necessário à adequação dessa estrutura à atividade empresarial proposta ${ }^{65}$.

Como uma das formas de se evitar a subcapitalização, discute-se a necessidade de fixação de capital social nominal mínimo ou suficiente, que asseguraria, ao menos em princípio, que o volume de capital próprio aplicado em determinada sociedade seria adequado ao desempenho de suas atividades e ao cumprimento de suas obrigações.

A principal distinção entre capital mínimo e capital suficiente reside no fato de o primeiro ser um valor fixo de capital social nominal da sociedade, enquanto o segundo é um quociente do balanço. Em outras palavras, o capital mínimo é um valor fixo e prédeterminado pela legislação, regra geral, em função do tipo societário adotado. Como exemplos de países que adotaram ou adotam esse sistema, podemos citar a Itália, a Alemanha e a Bélgica ${ }^{66}$.

As críticas apontadas em relação ao sistema de capital mínimo foram resumidas por Gustavo Saad Diniz ${ }^{67}$ em três pontuais aspectos:

(i) ineficiência da previsão de valores fixos em função da sua inevitável depreciação em processos inflacionários. A imutabilidade, ao menos temporária, dos valores de capital mínimo previstos nas legislações internas implica sua desatualização e a conseqüente incompatibilidade com o cenário econômico em que as sociedades estão organizadas;

(ii) tendência de subcapitalização das sociedades e esvaziamento do capital social mínimo com o início das atividades. O simples fato de a legislação interna prever um capital social mínimo a ser observado pelas sociedades no momento da sua constituição não assegura a manutenção desse limite mínimo durante toda a vida da sociedade e também não garante a inocorrência de estado de subcapitalização;

(iii) inexistência de uma cifra adequada ou suficiente para cada empresa. O consumo do capital de uma determinada sociedade varia em função de diferentes fatores, entre eles o tipo de atividade desempenhada, o mercado de

\footnotetext{
${ }^{65}$ PENTEADO, Mauro Rodrigues. op. cit., p. 40.

${ }^{66}$ Para maiores detalhes sobre o desenvolvimento da Legislação Italiana, Alemã e Belga sobre o assunto, vide DINIZ, Gustavo Saad. op. cit., p. 107-109.

${ }^{67}$ Id. Ibid., p. 109.
} 
atuação etc. Assim, impossível determinar um valor fixo de capital mínimo que possa ser considerado ideal para todas as empresas ${ }^{68}$.

Diferentemente do capital mínimo, o quociente do balanço previsto como idéia de capital suficiente é determinado por meio da proporção entre capital próprio e capital de terceiros, a qual deve necessariamente ser identificada em função da atividade desenvolvida pela empresa. Gustavo Saad Diniz trata do assunto com profundidade em sua Tese de Doutorado, defendida em 2007, e afirma que o sistema de capital suficiente é, em detrimento do sistema de capital mínimo, a tendência doutrinária atual sobre o tema ${ }^{69}$.

O sistema legal brasileiro não prevê qualquer valor mínimo de capital para a constituição de empresas e também não exige a adoção de um capital social adequado ao desempenho do objeto social ${ }^{70}$. A Lei das Sociedades Anônimas - Lei no 6.404/76 - prevê apenas a necessidade de definição do valor do capital social da sociedade no correspondente estatuto, sem impor qualquer tipo de parâmetro ou limitação à sua determinação.

Exceções a essa regra podem ser encontradas em casos específicos. As empresas comerciais exportadoras, por exemplo, devem observar o valor de capital mínimo exigido pelo Conselho Monetário Nacional ${ }^{71}$. Da mesma forma, as sociedades de trabalho temporário também devem ter capital mínimo correspondente a quinhentas vezes o valor do maior salário mínimo vigente no país ${ }^{72}$. Essas são apenas algumas das hipóteses em que um valor mínimo de capital social é exigido por lei. Entretanto, é importante notar que as exceções à regra são aplicáveis a determinados tipos de atividades, cujo exercício depende da obtenção de autorização pelas sociedades.

\footnotetext{
${ }^{68}$ Essa crítica pode ser comparada àquela imputada aos métodos de cálculo de preços de transferência previstos na Legislação Brasileira, os quais prevêem margens fixas, sem distinções específicas em função do tipo de atividade desenvolvida e do mercado de atuação dos contribuintes. Detalhes sobre o assunto podem ser encontrados em SCHOUERI, Luís Eduardo. Preços de transferência no direito tributário brasileiro. 2. ed. São Paulo: Ed. Dialética, 2006. p. 101-110.

${ }^{69}$ DINIZ, Gustavo Saad. op. cit., p. 110. Para maiores detalhes em relação a esse tema, veja PENTEADO, Mauro Rodrigues. op. cit., p. 15-31.

${ }^{70}$ XAVIER, José Tadeu Neves. A teoria da desconsideração da pessoa jurídica no novo Código Civil. Ajuris: Revista da Associação dos Juízes do Rio Grande do Sul, Porto Alegre, ano 30, n. 89, p. 179, mar. 2003.

${ }^{71}$ Decreto-Lei $\mathrm{n}^{\circ} 1.248 / 72$, artigo $2^{\circ}$, inciso III.

${ }^{72}$ Lei $n^{\circ} 6.019 / 74$, artigo $6^{\circ}$.
} 


\subsubsection{Os diferentes tipos de subcapitalização. A definição dos conceitos de subcapitalização nominal e subcapitalização material}

A subcapitalização pode ser classificada de duas diferentes formas: (i) subcapitalização originária ou superveniente; (ii) subcapitalização material ou nominal.

O critério de classificação da subcapitalização como originária ou superveniente é o momento em que esta se concretiza. A subcapitalização originária é aquela verificada logo na constituição da sociedade, quando o seu capital é determinado. Sob o ponto de vista societário, a subcapitalização originária implica a responsabilização ilimitada dos sócios, os quais têm o dever de assegurar adequada capitalização da sociedade. Por decorrência lógica, a subcapitalização superveniente é aquela verificada na expansão das atividades do objeto social. Nesse último caso, a conseqüência da concretização da subcapitalização implica, sob o ponto de vista societário, a responsabilidade pessoal apenas do sócio ou grupo de sócios que possuem o controle da sociedade ${ }^{73}$.

A segunda forma de classificação da subcapitalização das sociedades, i.e., a classificação entre subcapitalização material e nominal, é aquela de maior importância para o presente estudo, pelos motivos que serão expostos a seguir.

A subcapitalização nominal decorre da realização de empréstimos à sociedade, pelos seus sócios, passando estes últimos a concorrerem com os demais credores da sociedade em caso de eventual insucesso do empreendimento.

Por sua vez, na subcapitalização material, o financiamento da sociedade se dá principalmente, de forma excessiva, com capital de terceiros. Assim, nesse último caso, os riscos da atividade desempenhada pela sociedade são efetivamente transferidos dos sócios para os seus credores.

Na subcapitalização nominal, ainda que a transferência dos riscos da atividade seja conseqüência indireta da sua caracterização, a realização de volume excessivo de empréstimos pelos sócios busca principalmente assegurar o retorno do capital investido na sociedade (ou ao menos aumentar suas chances de devolução do valor investido).

\footnotetext{
${ }^{73}$ DINIZ, Gustavo Saad. op. cit., p. 111 e TÔRRES, Heleno Taveira. Direito tributário internacional: planejamento tributário e operações transnacionais, cit., p. 512.
} 
Abadan Jasmon e Junaid Shaikh confirmam esse entendimento, ao afirmarem que a realização de empréstimos por sócios em substituição ao incremento do investimento direto é a forma segura de se obter de volta o investimento realizado ${ }^{74}$.

É importante notar que, para a configuração da subcapitalização nominal, não é suficiente a verificação da existência de contratos de mútuo firmados entre a sociedade e seus sócios. Não se pode definir como subcapitalizada a sociedade que, por exemplo, realiza empréstimo com sócio apenas e tão-somente para reduzir os custos de uma determinada operação. Outros fatores devem ser levados em conta, como o estado financeiro da sociedade, o volume de recursos emprestados, o vínculo entre a sociedade e o mutuante.

Sobre esse assunto, Gustavo Saad Diniz afirma que Karsten Schmidt ${ }^{75}$ enumera três possíveis hipóteses em que há subcapitalização nominal: “(a) créditos transferidos à sociedade em estado de insolvência, que deixam de ser valores para saneamento, mas somente para a condução de negócios específicos; (b) créditos de saneamento para desvio de insolvência já caracterizada; (c) créditos transferidos para a sociedade sem grau de crédito ou em estágio de inidoneidade creditícia, que é medida pela situação financeira de liquidez da sociedade."

Sob o ponto de vista societário, independentemente da classificação como nominal ou material, a subcapitalização está diretamente relacionada aos direitos de crédito dos credores e à disfunção da limitação de responsabilidade inerente ao tipo societário adotado, assim como ao abuso de finalidade da personalidade jurídica ${ }^{76}$.

Sob o ponto de vista tributário, entretanto, a subcapitalização nominal ganha destaque em relação à subcapitalização material. Isso porque apenas nesse tipo de subcapitalização se dá a requalificação dos empréstimos dos sócios como financiamentos de capital próprio, gerando efeitos tributários evidentes em face da condição de credor do Fisco em relação à sociedade. Em outras palavras, os valores concedidos à sociedade sob a forma de contratos de mútuo firmados com seus sócios passam a ser tratados como investimentos diretos na sociedade e, como conseqüência, a remuneração correspondente, que seria paga sob a forma de juros atrelados ao empréstimo, passa a ser considerada

\footnotetext{
${ }^{74}$ JASMON, Abadan; SHAIKH, Junaid M. Tax strategies to discourage thin capitalization. Journal of International Taxation, Boston, v. 14, n. 4, p. 39, Apr 2003.

${ }^{75} \mathrm{O}$ entendimento de Karsten Schmidt foi extraído de DINIZ, Gustavo Saad. op. cit., p. 158.

${ }^{76}$ DINIZ, Gustavo Saad. op. cit., p. 84. José Tadeu Neves Xavier afirma, ainda, que a subcapitalização pode ser causa do reconhecimento da desconsideração da personalidade jurídica (XAVIER, José Tadeu Neves. op. cit., p. 179-183).
} 
dividendo, que possui tratamento tributário completamente diverso, conforme será analisado oportunamente.

Ivens Henrique Hubert, em artigo denominado "Subcapitalização de empresas: delineamento e tratamento nos âmbitos societário e tributário", elaborou quadro extremamente didático, que resume os aspectos da subcapitalização importantes ao Direito Tributário, contrapondo-os àqueles de maior relevância para o Direito Societário ${ }^{77}$.

\subsubsection{As regras de distribuição de lucros no Direito Brasileiro e a distribuição de lucros ilícita como mecanismo de subcapitalização nominal}

Pontes de Miranda define os dividendos como o "quociente dos lucros de que se pode deduzir o que se destina aos acionistas pelo número de ações" ${ }^{\text {78 }}$. Da mesma forma, Egberto Lacerda Teixeira e José Alexandre Tavares Guerreiro afirmam que os dividendos são "a parcela do lucro líquido a ser partilhada em dinheiro entre os acionistas" "79 . Ainda, em relação ao Direito Italiano, Cesare Vivante define o conceito de dividendos, nos mesmos termos, como o lucro líquido pago periodicamente aos sócios ${ }^{80}$.

De forma resumida, portanto, podemos afirmar que os dividendos são a remuneração dos sócios pelo capital próprio investido na sociedade, calculada em função dos resultados auferidos ${ }^{81}$.

Nos termos do artigo 201 da Lei das Sociedades Anônimas - Lei n ${ }^{\circ} 6.404 / 76^{82}$, o valor de dividendos passível de distribuição está limitado à soma dos montantes registrados

\footnotetext{
${ }^{77}$ HÜBERT, Ivens Henrique. Subcapitalização de empresas: delineamento e tratamento nos âmbitos societário e tributário. In: TÔRRES, Heleno Taveira. (Org.). Direito tributário internacional aplicado. São Paulo: Quartier Latin, 2004. v. 2, p. 574.

${ }^{78}$ MIRANDA, Francisco Cavalcanti Pontes de. op. cit., v. 50, p. 438.

${ }^{79}$ TEIXEIRA, Egberto Lacerda; GUERREIRO, José Alexandre Tavares. Das sociedades anônimas no direito brasileiro. São Paulo: José Bushatsky, 1979. p. 583.

${ }^{80}$ VIVANTE, Cesare. op. cit., v. 2, p. 383.

${ }^{81}$ Conforme artigo 109, inciso I, da Lei das Sociedades Anônimas - Lei n ${ }^{\circ}$ 6.404/76, todos os acionistas são titulares do direito essencial de participar dos lucros da companhia. Entretanto, esse direito não é concedido a todos os sócios em igualdade de condições. A participação nos lucros depende da espécie, classe e quantidade de ações detidas por cada um. Atualmente, a legislação prevê duas diferentes classes de dividendos, a saber: (i) dividendo obrigatório; e (ii) dividendo preferencial, sendo este último subdividido em dividendos preferenciais fixos e dividendos preferenciais mínimos. A despeito de existirem regras específicas aplicáveis a cada um desses tipos de dividendos, em função do objeto deste trabalho, o escopo do estudo foi delimitado pela definição do conceito, acima abordado, e a sua forma de cálculo, a ser analisada a seguir.

82،Artigo 201. A companhia somente pode pagar dividendos à conta de lucro líquido do exercício, de lucros acumulados e de reserva de lucros; e à conta de reserva de capital, no caso das ações preferenciais de que trata o parágrafo $5^{\circ}$ do artigo 17 . (...)"
} 
nas contas de lucro líquido do exercício, de lucros acumulados e de reserva de lucros. Em alguns casos, por exemplo, no pagamento de dividendos a acionistas detentores de ações preferenciais, a legislação autoriza expressamente a inclusão adicional do valor registrado na reserva de capital ${ }^{83}$.

Para esses fins, o lucro líquido do exercício é definido, a partir do lucro do exercício, como o resultado obtido após a dedução dos prejuízos acumulados, da provisão para o Imposto sobre a Renda e das participações estatutárias de empregados, administradores e partes beneficiárias ${ }^{84}$.

Previamente à distribuição do lucro líquido é necessária, ainda, a destinação de $5 \%$ (cinco por cento) desse valor à reserva legal prevista no artigo $193^{85}$ da Lei das Sociedades Anônimas - Lei $n^{\circ}$ 6.404/76. A referida reserva é limitada a $20 \%$ (vinte por cento) do capital social e destina-se a assegurar a sua integridade, podendo ser utilizada apenas para compensar prejuízos ou aumentar o capital social da sociedade. Os parágrafos $3^{\circ}$ e $6^{\circ}$ do artigo 17 da Lei das Sociedades Anônimas - Lei $n^{\circ}$ 6.404/76 - reforçam a essencial manutenção da integridade do capital social da sociedade, na medida em que vedam a distribuição de dividendos preferenciais em prejuízo do capital social. Exceção é feita apenas às hipóteses de liquidação da sociedade, nas quais essa vantagem tiver sido expressamente assegurada.

O pagamento de dividendos não precisa necessariamente ocorrer no final do exercício. A legislação vigente prevê a possibilidade de pagamento intermediário de

\footnotetext{
${ }^{83}$ A Lei no 11.638/07 alterou as regras previstas na Lei das Sociedades Anônimas - Lei no 6.404/76 em relação à constituição das reservas de capital.

${ }^{84}$ Conforme artigos 189, 190 e 191 da Lei das Sociedades Anônimas - Lei no 6.404/76.
}

“Artigo 189. Do resultado do exercício serão deduzidos, antes de qualquer participação, os prejuízos acumulados e a provisão para o Imposto sobre a Renda.

Parágrafo único. o prejuízo do exercício será obrigatoriamente absorvido pelos lucros acumulados, pelas reservas de lucros e pela reserva legal, nessa ordem.

Artigo 190. As participações estatutárias de empregados, administradores e partes beneficiárias serão determinadas, sucessivamente e nessa ordem, com base nos lucros que remanescerem depois de deduzida a participação anteriormente calculada.

Parágrafo único. Aplica-se ao pagamento das participações dos administradores e das partes beneficiárias o disposto nos parágrafos do artigo 201.

Artigo 191. Lucro líquido do exercício é o resultado do exercício que remanescer depois de deduzidas as participações de que trata o artigo 190."

85“Artigo 193. Do lucro líquido do exercício, $5 \%$ (cinco por cento) serão aplicados, antes de qualquer outra destinação, na constituição da reserva legal, que não excederá de $20 \%$ (vinte por cento) do capital social.

Parágrafo $1^{\circ}$. A companhia poderá deixar de constituir a reserva legal no exercício em que o saldo dessa reserva, acrescido do montante das reservas de capital de que trata o parágrafo $1^{\circ}$ do artigo 182 , exceder de $30 \%$ (trinta por cento) do capital social.

Parágrafo $\mathbf{2}^{\mathbf{0}}$. A reserva legal tem por fim assegurar a integridade do capital social e somente poderá ser utilizada para compensar prejuízos ou aumentar o capital." 
dividendos. Segundo o artigo 204 da Lei das Sociedades das Anônimas - Lei no 6.404/76, a sociedade, cujo estatuto expressamente autorizar o levantamento de balanço semestral, poderá distribuir dividendos à conta do lucro apurado nesse balanço.

É possível, ainda, a distribuição de dividendos em períodos menores. No entanto, nesse caso, além do necessário levantamento de balanço, o valor total dos dividendos pagos no semestre não pode exceder o montante das reservas de capital.

Os dividendos intermediários podem também ser distribuídos com base na conta de lucros acumulados ou de reservas de lucros existentes no último balanço anual ou semestral da sociedade.

Existe a possibilidade de a assembléia geral deliberar distribuição de dividendos inferior ao obrigatório, ou, ainda, a retenção de todo o lucro líquido. Essa hipótese nada mais é do que o autofinanciamento da sociedade. Em se tratando de companhias abertas, a distribuição reduzida ou a retenção de dividendos será possível apenas na hipótese de sua utilização exclusiva para a captação de recursos por debêntures não conversíveis em ações. Quanto às companhias fechadas, a referida alternativa é expressamente vedada no caso de serem controladas por companhias abertas que não se enquadrem na condição prevista na frase anterior.

No Direito Italiano existe jurisprudência que aponta para a possibilidade de formação de reserva extraordinária em prejuízo da distribuição de dividendos, desde que não se trate de desvio de interesse da sociedade ${ }^{86}$.

Os parágrafos $4^{\circ}$ e $5^{\circ}$ do artigo 202 da Lei das Sociedades Anônimas - Lei $\mathrm{n}^{\circ}$ $6.404 / 76^{87}$ - asseguram, ainda, que a distribuição de dividendos não será obrigatória no exercício social em que os órgãos da administração informarem à assembléia geral ordinária ser ele incompatível com a situação financeira da companhia. Nesse caso, o

\footnotetext{
${ }^{86}$ DELla VALLE, Francesca; DELla VALlE, Sandra. Codice Civile annotato con la jurisprudenza. Milano: Giuffrè, 2005. Sobre o assunto no direito brasileiro, veja COMPARATO, Fábio Konder; SALOMÃO FILHO, Calixto. O poder de controle na sociedade anônima. 4. ed. Rio de Janeiro: Forense, 2005. p. 395-398.

87،'Parágrafo $4^{\circ}$. O dividendo previsto neste artigo não será obrigatório no exercício social em que os órgãos da administração informarem à assembléia-geral ordinária ser ele incompatível com a situação financeira da companhia. O conselho fiscal, se em funcionamento, deverá dar parecer sobre essa informação e, na companhia aberta, seus administradores encaminharão à Comissão de Valores Mobiliários, dentro de 5 (cinco) dias da realização da assembléia-geral, exposição justificativa da informação transmitida à assembléia.

Parágrafo $5^{\circ}$. Os lucros que deixarem de ser distribuídos nos termos do parágrafo $4^{\circ}$ serão registrados como reserva especial e, se não absorvidos por prejuízos em exercícios subseqüentes, deverão ser pagos como dividendo assim que o permitir a situação financeira da companhia."
} 
conselho fiscal, se existente, deverá dar parecer sobre essa situação e, em se tratando de companhias abertas, seus administradores deverão enviar justificativa à Comissão de Valores Mobiliários (CVM). Os lucros não distribuídos por esse motivo deverão integrar a reserva especial e, se não absorvidos por prejuízos em exercícios subseqüentes, deverão ser pagos a título de dividendos assim que o permitir a situação financeira da companhia.

As regras para definição do valor de dividendos passível de distribuição (inclusive a sócios residentes no exterior) permitem-nos concluir que existem três principais requisitos para o seu pagamento aos sócios: (i) obtenção de resultado positivo da sociedade no mesmo período em que se pretende pagar dividendos (existência de lucros após o encerramento do exercício social) ou em períodos anteriores (existência de lucros acumulados ou reserva de lucros); (ii) absorção de todos os prejuízos ${ }^{88}$; (iii) manutenção da integridade do capital social e da situação financeira da sociedade.

No Direito Italiano, segundo Cesare Vivante, a distribuição de dividendos depende de duas condições, quais sejam: (i) os dividendos devem necessariamente resultar de balanço devidamente aprovado $^{89}$ (condição suspensiva); (ii) a assembléia não pode suspender o pagamento dos dividendos mediante alteração do estatuto (condição resolutiva $)^{90}$. A essas duas premissas apontadas por Cesare Vivante em relação à distribuição de dividendos, Francesco Ferrara Jr. adiciona a necessidade de existência (i) de lucro, sendo que este não pode ser vinculado à compensação de prejuízos, e (ii) de capital suficiente para o pagamento ${ }^{91}$.

Partindo dessas premissas estabelecidas pela Lei das Sociedades Anônimas - Lei $n^{\circ} 6.404 / 76$ - para a distribuição de dividendos, a eventual obrigação de abatimento de dívidas com os sócios ou mesmo o pagamento da sua correspondente remuneração pela sociedade deveria ser cumprida em momento anterior à definição do lucro líquido de determinado período, base da distribuição dos dividendos.

\footnotetext{
${ }^{88}$ Vale mencionar que, conforme artigo 173 da Lei das Sociedades Anônimas - Lei nº 6.404/76 e artigo 64, parágrafo $3^{\circ}$, do Decreto-lei $\mathrm{n}^{\circ} 1.598 / 77$, as perdas podem ser absorvidas para fins de redução do capital social, sem gerar conseqüências cambiais ou tributárias.

${ }^{89}$ A Legislação Brasileira (mais especificamente o artigo 192 da Lei das Sociedades Anônimas - Lei $n^{\circ}$ 6.404/76) vigente prevê que a proposta de destinação a ser dada ao lucro líquido do exercício deverá, com as demonstrações financeiras do exercício, ser apresentada pelos órgãos da administração e aprovada pela assembléia geral ordinária.

${ }^{90}$ VIVANTE, Cesare. op. cit., v. 2, p. 383.

${ }^{91}$ FERRARA JR., Francesco. op. cit., p. 576. No mesmo sentido, veja DELLA VALLE, Francesca; DELLA VALLE, Sandra. op. cit.
} 
Conforme mencionado, o lucro líquido do exercício é definido, a partir do lucro do exercício, como o resultado obtido após a dedução dos prejuízos acumulados, da provisão para o Imposto sobre a Renda e das participações estatutárias de empregados, administradores e partes beneficiárias. O lucro do exercício nada mais é do que a diferença positiva entre as receitas auferidas, em sua maioria, com o desempenho da atividade empresarial e as correspondentes despesas incorridas pela sociedade no mesmo período ${ }^{92}$.

Nesse sentido, as remunerações atreladas a empréstimos, i.e., os juros, devem ser deduzidas do valor total das receitas auferidas pela sociedade, com as demais despesas incorridas no mesmo exercício, resultando no lucro do exercício, base para a definição do lucro líquido nos termos acima.

É claro, portanto, que, ao realizarem empréstimos à sociedade, seus sócios asseguram o recebimento de remuneração pelo capital investido, ainda que sob a forma de juros e não de dividendos. Em outras palavras, mesmo na hipótese de o lucro líquido da sociedade não ser suficiente para distribuir dividendos, os sócios são remunerados mediante o pagamento de juros.

Conforme visto na parte final do item 2.2.1., se caracterizada a subcapitalização nominal, o pagamento de juros passa a ser qualificado como distribuição de dividendos. Como decorrência lógica dessa requalificação, tem-se que essa distribuição de dividendos pode ter sido realizada com base em lucros inexistentes e, portanto, deve ser considerada ilícita. Na lição de Giuseppe Ferri, são casos de distribuição ilícita de dividendos aqueles nos quais os lucros não foram efetivamente auferidos ou nos quais os dividendos superam os lucros passíveis de distribuição ${ }^{93}$.

Sob perspectiva econômica e contábil, Luciano Scherer e Eliseu Martins destacam a importância do adequado dimensionamento do valor dos dividendos distribuídos por uma sociedade. Somente é possível distribuir como dividendo a parcela do lucro que excede o valor a ser necessariamente retido na sociedade para garantir a manutenção do seu capital.

\footnotetext{
${ }^{92}$ IUDÍCIBUS, Sérgio de; MARTINS, Eliseu; KANITZ, Stephen Charles; RAMOS, Alkíndar de Toledo; CASTILHO, Edison; BENATTI, Luiz; WEBER FILHO, Eduardo; DOMINGUES JÚNIOR, Ramon. Contabilidade introdutória. 9. ed. São Paulo: Atlas, 1998. p. 66-67.

${ }^{93}$ FERRI, Giuseppe. Le societá - Trattato di diritto civile, cit., n. 3, v. 10, p. 576-578. A esses dois casos de distribuição ilícita de dividendos, Giuseppe Ferri acrescenta aqueles em que os lucros distribuídos não foram objeto de balanço devidamente aprovado nos termos legais.
} 
A distribuição de dividendos em excesso pode ocasionar a descapitalização da sociedade e, ainda, a sua descontinuação ${ }^{94}$.

${ }^{94}$ SCHERER, Luciano Márcio; MARTINS, Eliseu. Manutenção de capital e distribuição de dividendos. Revista da FAE, Curitiba, v. 6, n. 2, p. 66, maio/dez., 2003. 


\section{CAPÍTULO II. O TRATAMENTO TRIBUTÁRIO DISPENSADO ÀS FORMAS DE REMUNERAÇÃO DO CAPITAL FINANCIADO POR MEIO DE CAPITAL PRÓPRIO E DE CAPITAL DE TERCEIROS. OS IMPACTOS TRIBUTÁRIOS DECORRENTES DA CARACTERIZAÇÃO DA SUBCAPITALIZAÇÃO NOMINAL}

1. A dupla tributação dos lucros auferidos pelas sociedades e os métodos de integração tributária propostos para a resolução desta ineficiência econômicofinanceira

Considerando que os sócios são os reais beneficiários dos lucros gerados pelas sociedades, discutiu-se muito, principalmente na Europa, nos Estados Unidos da América e no Canadá, na segunda metade do século XX, e ainda se discute, a legitimidade da tributação dos lucros nas pessoas jurídicas geradoras de riquezas como contribuintes autônomos, ao invés de tributá-los diretamente nas pessoas, físicas ou jurídicas, dos sócios ${ }^{95}$.

Em um cenário hipotético, em que fosse possível identificar o lucro de determinada sociedade com um carimbo, poderíamos verificar a sua transferência para os sócios por meio de distribuição de dividendos. Os lucros gerados por determinada empresa são apenas diretamente auferidos pela sociedade, uma vez que, em última instância, são auferidos pelos seus sócios, idealizadores e executores do negócio rentável.

Conforme analisado no item 2.2.2. do Capítulo anterior, o lucro do exercício nada mais é do que a diferença positiva entre as receitas auferidas, em sua maioria com o desempenho da atividade empresarial, e as correspondentes despesas incorridas pela sociedade. Dentre as despesas, incluem-se os gastos com tributos, por exemplo, o Imposto sobre a Renda incidente sobre o lucro da sociedade. Os dividendos distribuídos aos sócios

\footnotetext{
${ }^{95}$ A tributação das sociedades como contribuintes autônomos do Imposto sobre a Renda é denominada, no Direito Norte-Americano, como separate entity approach.
} 
decorrem, por conseguinte, de lucros auferidos pela sociedade, após a sua tributação pelo Imposto sobre a Renda.

Segundo Sérgio de Iudícibus, Eliseu Martins e Ernesto Gelbcke, o lucro líquido apurado "é o que se pode chamar de lucros dos acionistas pois, além dos itens normais já se deduzem despesas como o Imposto sobre a Renda e as participações sobre os lucros a outros que não os acionistas, de forma que o lucro líquido demonstrado é o valor final a ser adicionado ao patrimônio líquido da empresa que, em última análise, pertence aos acionistas, ou é distribuído como dividendo" ${ }^{96}$.

A despeito de ser exatamente o mesmo rendimento, os dividendos podem estar novamente sujeitos à tributação no nível dos sócios, ocasionando a sua dupla tributação ${ }^{97}$ pelo Imposto sobre a Renda. Ainda que auferido por sujeitos passivos diversos - pessoa jurídica e respectivos sócios - trata-se, na realidade, do mesmo rendimento, que é tributado duplamente em dois momentos distintos.

No mesmo sentido, Abadan Jasmon e Junaid Shaikh afirmam que, na teoria, os dividendos distribuídos não deveriam estar sujeitos a tributação no nível dos sócios, uma vez que, o imposto já foi pago no nível da sociedade. Entretanto, na prática, os dividendos são tributados novamente quando estão em poder dos sócios ${ }^{98}$.

Sob a perspectiva econômico-financeira, a eventual tributação dos lucros no nível das sociedades e também no nível dos seus sócios cria desigualdades horizontais e verticais, interfere nas decisões financeiras dos negócios e distorce a alocação de capital na sociedade, segundo lição de Charles McLure Jr. ${ }^{99}$.

Buscando evitar a concretização de problemática jurídica decorrente dessa dupla exação, alguns países criaram novos impostos para determinar a incidência sobre a renda dos sócios, pessoas físicas, e das sociedades, pessoas jurídicas. Os Estados Unidos da

\footnotetext{
${ }^{96}$ IUDÍCIBUS, Sérgio de; MARTINS, Eliseu; GELBCKE, Ernesto Rubens. Manual de contabilidade das sociedades por ações. 7. ed. São Paulo: Atlas, 2007. p. 8.

${ }^{97}$ Tecnicamente, não se trata de dupla tributação, mas de bis in idem, tendo em vista que, nessa hipótese, se dá a tributação da mesma matéria, por duas vezes, pelo mesmo ente tributante. Para os fins do presente trabalho, no entanto, convencionou-se utilizar o termo dupla tributação em sentido econômico e não jurídico. A diferença entre os conceitos de dupla tributação e bis in idem é tratada por José Eduardo Soares de Melo em Curso de direito tributário. 5. ed. São Paulo: Ed. Dialética, 2004. p. 123-125.

${ }^{98}$ Segundo esses autores, existem jurisdições, como é o caso dos Estados Unidos da América, que adotam a dupla tributação dos lucros das sociedades para desencorajar as complexas estruturas societárias dos grupos em virtude de problemas de governança corporativa. JASMON, Abadan; SHAIKH, Junaid M. op. cit., p. 38.

${ }^{99}$ McLURE JR., Charles. The case for integrating the income taxes. National Tax Journal (pre-1986), Washington, v. 28, n. 3, p. 257, Sept. 1975.
} 
América, a Alemanha, a França e a Inglaterra são exemplos de países que criaram, entre 1920 e 1965, novas figuras tributárias, diferentes daquelas já existentes e incidentes sobre os lucros das pessoas físicas ${ }^{100}$. Ou seja, esses países criaram uma espécie de ficção para mascarar a incidência tributária duplicada sobre os lucros auferidos pelas sociedades primeiro no nível da pessoa jurídica e, em um segundo momento, no nível das pessoas físicas suas sócias.

No Brasil, com a publicação do Decreto n 4.625, em 31 de dezembro de 1922 (Lei Orçamentária para o exercício de 1923$)^{101}$, criou-se o Imposto Geral sobre a Renda, que era devido indistintamente por pessoas físicas e jurídicas, com periodicidade anual, sobre o conjunto dos rendimentos líquidos auferidos, de qualquer origem.

Após sucessivas alterações da Legislação Tributária Brasileira, pode-se dizer que hoje existem dois impostos que incidem sobre a renda e que, sob o ponto de vista jurídico,

${ }^{100}$ Para maiores detalhes sobre o assunto, vide TILBERY, Henry. Imposto de renda, pessoas jurídicas;
integração entre sociedade e sócios. São Paulo: Atlas, 1985. p. 30; SELIGMAN, Edwin R. A. The income
tax, history, theory and practice. 2. ed. New York: A. M. Kelly, 1970; LAUFENBURGER, Henry.
Finanças comparadas. 2. ed. Rio de Janeiro: Ed. Financeiras, 1953; BEATTIE, C. N. Elements of the law
of income and capital gains taxation. Londres: Stevens \& Sons Ed., 1968.

101"Artigo 31. Fica instituído o imposto geral sobre a renda, que será, devido, annualmente, por toda a pessoa physica ou jurídica, residente no território do paiz, e incidirá, em cada caso, sobre o conjunto liquido dos rendimentos de qualquer origem.

I. As pessoas não residentes no paiz e as sociedades com séde no estrangeiro pagarão o imposto sobre a renda liquida, que lhes fôr apurada dentro do território nacional.

II. É isenta do imposto a renda annual inferior a 6:000\$ (seis contos de réis), vigorando para a que exceder dessa quantia a tarifa que for annualmente fixada pelo Congresso Nacional.

III. Será considerado liquido, para o fim do imposto, o conjunto dos sendimentos auferidos de qualquer fonte, feitas as deducções seguintes:

a) imposto e taxas;

b) juros de devidas, por que responda o contribuinte;

c) perdas extraordinárias, provenientes de casos fortuitos ou força maior, como incêndio, tempestade, naufrágio o accidentes semelhantes a esses, desde que tais perda não sejam compensadas por seguros ou indemnizações;

d) as despezas ordinárias realizadas para conseguir e assegurar a renda.

IV. Os contribuites de renda entre 6:000\$ (seis contos de réis) e 20:000\$ (vinte contos de réis) terão deducção de $2 \%$ (dous por cento) sobre o montante do imposto devido por pessoa que tenha a seu cargo, não podendo exceder, em caso algum, essa deducção a 50 \% (cincoenta por cento) da importância normal do imposto.

V. O imposto será arrecadado por lançamento, servindo de base a declaração do contribuinte, revista pelo agente do fisco e com recurso para autoridade administrativa superior ou pára arbitramento. Na falta de declaração o lançamento se fará ex-officio. A impugnação por parte do agente do fisco ou o lançamento exofficio terão de apoiar-se em elementos comprobatórios do montante da renda e da taxa devida.

VI. A cobrança do imposto será feita cada anno sobre a base do lançamento realizado no anno immediatamente anterior.

VII. O poder Executivo providenciará expedindo os precisos regulamentos e instrucções, e executando as medidas necessárias aos lançamentos e instrucções, e executando as medidas necessárias ao lançamento, por fórma que a arrecadação do imposto se torne effectiva em 1924.

VIII. Em o regulamento, que expedir o poder Executivo poderá impor multas até o máximo de 5:000\$ (cinco contos de réis)." 
possuem natureza diversa: Imposto sobre a Renda devido pelas pessoas físicas e Imposto sobre a Renda devido pelas pessoas jurídicas ${ }^{102}$.

É importante notar, entretanto, que a criação de novos tributos com denominação diversa em nada altera a dupla tributação dos lucros auferidos pelas sociedades. Mesmo com a existência de novas figuras tributárias, é certo que há dupla exação do ponto de vista econômico e, independentemente de os sócios serem pessoas físicas ou jurídicas, é a análise dessa efetiva sobreposição do Imposto sobre a Renda sobre os lucros auferidos pelas sociedades que importa ao presente estudo.

Não obstante a ineficiência econômico-financeira claramente atrelada à dupla tributação dos lucros das sociedades, Henry Tilbery, fazendo referência a estudo de John F. Due, aponta alguns motivos que podem ser utilizados para justificar a tributação das sociedades como contribuintes autônomos do Imposto sobre a Renda ${ }^{103}$. São eles: (i) as sociedades são dotadas de personalidade jurídica, com patrimônio próprio ${ }^{104}$, destacado daquele dos seus sócios; (ii) regra geral, exceto pelo sócio majoritário, os demais sócios não possuem controle sobre os negócios da sociedade; (iii) a eliminação da tributação no nível das sociedades implicaria redução das receitas do Estado, que seria provavelmente compensada com a instituição de novas medidas tributárias que, por sua vez, poderiam trazer efeitos ainda mais danosos.

Esse não é um problema exclusivo da distribuição de lucros realizada a sócio residente no mesmo território da sociedade. A dupla tributação dos lucros também pode se dar na distribuição a sócios não-residentes, e, nesse caso, a resolução do problema pode ser

\footnotetext{
${ }^{102}$ Conforme podemos depreender da leitura do inciso I do artigo 154 da Constituição Federal, o fato gerador e a base de cálculo são os critérios eleitos para a identificação dos impostos. A sua denominação, forma de exigência, razões que motivaram a sua criação e até mesmo o próprio sujeito passivo são, portanto, critérios irrelevantes para sua identificação. A eleição da base de cálculo como o elemento essencial para confirmar o verdadeiro critério material da hipótese tributária e, portanto, a natureza jurídica do imposto, encontra respaldo em grandes doutrinadores, por exemplo, Alfredo Augusto Becker, Paulo de Barros Carvalho e Geraldo Ataliba. Detalhes sobre o tema podem ser encontrados no seguinte artigo de autoria de Luís Eduardo Schoueri: Discriminação de competências e competência residual. In: ___ ; ZILVETI, Fernando Aurélio (Coord.). Direito Tributário: estudos em homenagem a Brandão Machado. São Paulo: Ed. Dialética, 1998. p. 89-103. Para mais detalhes, veja também BECKER, Alfredo Augusto. Teoria geral do direito tributário. 4. ed. São Paulo: Ed. Noeses, 2007; CARVALHO, Paulo de Barros. Curso de direito tributário. 15. ed. São Paulo: Saraiva, 2003. Id. Direito tributário: fundamentos jurídicos da incidência. 2. ed. São Paulo: Saraiva, 1999; e ATALIBA, Geraldo. Hipótese de incidência tributária. 6. ed. São Paulo: Malheiros Ed., 2005.

${ }^{103}$ Tendo em vista o objeto do presente estudo, optou-se por excluir a análise detalhada das diversas correntes doutrinárias sobre a justificativa do tratamento da pessoa jurídica como contribuinte autônomo do Imposto sobre a Renda, limitando-se a citar as razões mais relevantes, na lição de Henry Tilbery, para a manutenção desse sistema de tributação. Detalhes sobre o tema podem ser encontramos em TILBERY, Henry. op. cit., p. 31-40.

${ }^{104}$ José Waldecy Lucena diferencia de forma extremamente didática os conceitos de capital e patrimônio, fazendo clara referência à individualidade do patrimônio da sociedade em relação ao patrimônio de seus sócios (LUCENA, José Waldecy. Das sociedades limitadas. 6. ed. Rio de Janeiro: Ed. Renovar, 2005. p. 268-270).
} 
ainda mais difícil, uma que vez que os respectivos Estados possuem o poder soberano para instituir um encargo tributário, independentemente da existência de imposição tributária em outro Estado sobre os mesmos rendimentos ${ }^{105}$.

É importante ressaltar que os acordos para evitar a dupla tributação, assim como as medidas unilaterais adotadas pelos Estados (por exemplo, a concessão de crédito ou isenção tributária), visam eliminar a efetiva bitributação dos dividendos, que estão sujeitos à retenção na fonte ${ }^{106}$ no momento do seu pagamento ${ }^{107}$ e também no Estado de residência do beneficiário. No Capítulo IV deste trabalho, serão analisadas em detalhes as disposições nesse sentido previstas, no modelo de acordo, para evitar a dupla tributação, proposto pela Organização de Cooperação e Desenvolvimento Econômico - OCDE (doravante denominada OCDE).

\subsection{A análise dos métodos de integração propostos para a eliminação ou mitigação da dupla tributação dos lucros auferidos pelas sociedades}

A problemática da dupla tributação dos lucros das sociedades é geralmente tratada por meio do estudo da integração entre a sociedade e seus sócios e da aplicação de métodos que procuram reduzir ou eliminar seus efeitos econômicos. Um interessante artigo publicado por George F. Break no National Tax Journal resume os pontos positivos e negativos relativos à adoção do sistema de integração, comparando-os com aqueles inerentes ao sistema clássico de tributação dos lucros das sociedades em dois níveis: na sociedade e nos seus sócios ${ }^{108}$. Jennifer Babcock ${ }^{109}$ realizou comparação ainda mais

\footnotetext{
${ }^{105}$ Heleno Taveira Tôrres denomina esse efeito como “dupla tributação por distribuição societária internacional” e, citando Rafaello Lupi, afirma que a única diferença para a dupla tributação interna dos lucros é a existência de uma fronteira entre a sociedade e seus sócios (TÔRRES, Heleno Taveira. Pluritributação internacional sobre as rendas de empresas. 2. ed. São Paulo: Ed. Revista dos Tribunais, 2001. p. 412-415).

${ }^{106}$ Por retenção na fonte, entenda-se a tributação a cargo do beneficiário dos rendimentos, aplicável no momento do seu pagamento, e não a tributação dos lucros no nível da pessoa jurídica.

${ }^{107}$ Conforme será analisado, esse não é o caso do Brasil que, desde 1996, prevê a isenção do Imposto sobre a Renda sobre dividendos.

${ }^{108}$ BREAK, George F. Integration of the corporate and personal income taxes. National Tax Journal (pre1986). Washington, v. 22, n. 1, p. 39-41, Mar. 1969.

${ }^{109}$ BABCOCK, Jennifer. The effects of imputation systems on multinational investment, financing, and income-shifting strategies. The Journal of the American Taxation Association, Sarasota, v. 22, n. 2, p. 1-21, Fall 2000.
} 
aprofundada sobre esses sistemas de tributação em um artigo publicado no The Journal of the American Taxation Association ${ }^{110}$.

A despeito de inúmeros autores estrangeiros terem discutido o tema com profundidade, por exemplo, John F. Due, Charles McLure Jr. e Stanley S. Surrey, o trabalho de maior expressão sobre o tema publicado no país é de autoria de Henry Tilbery, que brilhantemente analisou a problemática exposta com base em autores e cenários estrangeiros, trazendo elementos para a análise do cenário brasileiro e propondo soluções para o sistema clássico de tributação então adotado no País.

Para tanto, Henry Tilbery identificou ${ }^{111}$ três diferentes métodos de integração entre a tributação no nível das sociedades e no nível dos seus sócios, cada um com base em técnicas próprias, que visam eliminar ou mitigar a problemática decorrente da dupla tributação dos lucros. São eles: (i) método das sociedades de pessoas ${ }^{112}$; (ii) método de integração parcial $^{113}$, o qual se subdivide em (ii.a.) alíquota diferenciada ${ }^{114}$; (ii.b.) exclusão dos dividendos recebidos ${ }^{115}$; (ii.c.) crédito dos dividendos recebidos ${ }^{116}$; (ii.d.) dedução dos dividendos pagos ${ }^{117}$; (ii.e.) retenção ${ }^{118}$; (iii) método de integração total ${ }^{119}$ que, por sua vez, subdivide-se em (iii.a.) eliminação da tributação das pessoas jurídicas em separado e tributação nas pessoas físicas dos lucros distribuídos e dos ganhos de capital; (iii.b.) distribuição de lucros e atribuição dos lucros retidos ${ }^{120}$.

O método das sociedades de pessoas é o mais simples deles e está baseado na idéia de que a sociedade, ainda que dotada de personalidade jurídica, consiste em mero instrumento de condução dos lucros auferidos para os seus sócios. Em outras palavras, o método das sociedades de pessoas depende do reconhecimento da transparência físcal das sociedades, o que, nas palavras de Heleno Taveira Tôrres, significa dizer que, para fins meramente fiscais, a legislação permite "que o Fisco desconsidere a separação existente,

\footnotetext{
${ }^{110}$ Diante do fato de já termos apontado a nossa preocupação em relação ao assunto no item 1 deste Capítulo, os demais aspectos, positivos ou negativos, desses sistemas serão desconsiderados para os fins deste trabalho.

${ }^{111}$ Os métodos de integração propostos por Henry Tilbery são, em sua maioria, baseados no trabalho de McLURE JR., Charles. Must corporate income be taxed twice?: a Report of a Conference Sponsored by the Fund of Public Research and the Brookings Institution. Brookings Institution Press, 1979.

${ }^{112}$ Também conhecido como The Partnership Method.

${ }^{113}$ Também conhecido como Partial Integration Methods.

${ }^{114}$ Também conhecido como Split Rate Method.

${ }^{115}$ Também conhecido como Dividend Received Exclusion.

${ }^{116}$ Também conhecido como Dividend Received Credit.

${ }^{117}$ Também conhecido como Dividend Paid Deduction.

${ }^{118}$ Também conhecido como Withholding Method.

${ }^{119}$ Também conhecido como Total Integration Method.

${ }^{120}$ Também conhecido como Distribution and Allocation-Carter approach.
} 
passando a qualificar as atividades de produção de rendimentos atribuídas diretamente às pessoas proprietárias ou controlantes da entidade: os sócios" ${ }^{\prime 121}$. Por essa lógica, qualquer tributação dos lucros no nível da pessoa jurídica seria desprezada e estes seriam considerados rendimentos dos próprios sócios e assim tributados.

Os métodos de integração parcial, diferentemente do método das sociedades de pessoas e dos métodos de integração total, não evitam completamente a tributação dos lucros em ambos os níveis, i.e., das pessoas jurídicas e dos seus sócios, mas apenas mitigam a carga incidente.

Stanley S. Surrey afirma que a principal diferença entre os métodos de integração total e parcial reside na eliminação da dupla tributação, em relação aos lucros retidos e não distribuídos, que é verificada apenas na integração total. Essa diferença será demonstrada exaustivamente na análise individual de cada um dos métodos de integração total e parcial $^{122}$. Quanto aos efeitos econômicos decorrentes da adoção desses métodos, Martin Feldstein e Daniel Frisch os analisam em artigo denominado Corporate tax integration: the estimated effects on capital accumulation and tax distribution of two integration proposals $^{123}$.

A primeira espécie de método de integração parcial a ser analisada é a da alíquota diferenciada. Segundo esse método, a redução do gravame dar-se-ia mediante a aplicação de alíquotas diversas aos lucros auferidos pela pessoa jurídica e aos dividendos distribuídos. Quanto aos lucros auferidos pela pessoa jurídica e ainda não distribuídos (tributação no nível da pessoa jurídica, portanto), sugere-se a aplicação de alíquota mais elevada. Em contrapartida, a alíquota aplicável na fonte na distribuição dos lucros seria reduzida, mitigando os efeitos econômicos da tributação pela mesma alíquota aplicável no nível da sociedade.

Nesse método, ainda que reduzida a carga tributária total, a tributação duplicada dos lucros é parcialmente mantida, uma vez que existe a previsão de retenção na fonte do Imposto sobre a Renda no momento da distribuição dos lucros.

\footnotetext{
${ }^{121}$ TÔRRES, Heleno Taveira. Juros sobre capital próprio - autonomia privada nos investimentos societários e suas implicações em matéria tributária, cit., v. 4, p. 362. Vale ressaltar que o próprio Heleno Taveira Tôrres destaca que a transparência fiscal pode emanar tanto do tipo societário adotado, como pode ser atribuída por simples ficção legal.

${ }^{122}$ SURREY, Stanley S. Reflections on "integration" of corporation and individual income taxes. National Tax Journal (pre-1986), Washington, v. 28, n. 3, p. 338, Sept. 1975.

${ }^{123}$ FELDSTEIN, Martin; FRISCH, Daniel. Corporate tax integration: the estimated effects on capital accumulation and tax distribution of two integration proposals. National Tax Journal (pre-1986), Washington, v. 30, n. 1, p. 37-52, Mar 1977.
} 
Heleno Taveira Tôrres adiciona, em relação ao método da alíquota diferenciada, a possibilidade de haver tributação no nível dos sócios, além daquela decorrente da retenção do imposto na fonte no momento do pagamento dos dividendos. Nesse caso, entretanto, sugere que o imposto retido na fonte seja tratado como antecipação do imposto devido pelos sócios ${ }^{124}$.

Conforme ensina Henry Tilbery ${ }^{125}$, o método de integração parcial da alíquota diferenciada foi, em 1963, recomendado aos integrantes do então Mercado Comum Europeu visando, principalmente, à redução da carga tributária aplicável aos dividendos nas relações transnacionais. Apesar de muitos países membros do Mercado Comum Europeu terem efetivamente adotado esse método, em um segundo momento, diante da sua eficácia limitada, os próprios membros sugeriram a adoção da imputação, aos sócios, dos lucros auferidos pela sociedade ${ }^{126}$.

O segundo método de integração parcial é o da exclusão dos dividendos recebidos. Esse método elimina a dupla tributação dos lucros no nível das sociedades, mas não evita completamente os seus efeitos econômicos.

Apesar de, conforme esse método, os dividendos não estarem sujeitos à tributação no nível dos sócios, mas tão-somente no nível da sociedade, não existe previsão de dedutibilidade desses valores para a fonte pagadora dos recursos, o que torna esse método pouco eficaz. Isso porque, ainda que a carga tributária total seja reduzida, os efeitos dessa redução estão concentrados na figura dos sócios e não da sociedade, para a qual o financiamento mediante capital de terceiros ${ }^{127}$ continua mais atraente em virtude da dedutibilidade dos juros remuneratórios.

O terceiro método de integração parcial, i.e., crédito dos dividendos recebidos, consiste na concessão, aos sócios, de crédito do Imposto sobre a Renda, em valor correspondente ao imposto pago pela sociedade em relação àqueles rendimentos.

\footnotetext{
${ }^{124}$ TÔRRES, Heleno Taveira. Juros sobre capital próprio - autonomia privada nos investimentos societários e suas implicações em matéria tributária, cit., v. 4, p. 363.

${ }^{125}$ TILBERY, Henry. op. cit., p. 43, 48-49.

${ }^{126}$ Henry Tilbery destaca, na mesma obra, que a Alemanha, fugindo à regra, combinou ambos os métodos, quais sejam, o da imputação e o das alíquotas diferenciadas. No mesmo sentido, vide McLURE JR., Charles. Must corporate income be taxed twice?: a Report of a Conference Sponsored by the Fund of Public Research and the Brookings Institution, cit., p. 3 e 48.

${ }^{127}$ Nesse sentido, o financiamento do capital aplicado por meio de empréstimos de sócios é mais atraente do que o financiamento realizado por meio de capital próprio, o qual, conforme visto anteriormente, é remunerado pela figura dos dividendos.
} 
A concessão do crédito do imposto pago pela sociedade sobre os dividendos possui efeito similar àquele conseguido pelo método da exclusão dos dividendos recebidos. Isso porque, ao invés de excluir os dividendos recebidos da base de cálculo do Imposto sobre a Renda devido pelos sócios, esse método inclui esses valores na referida base tributável, mas concede, em contrapartida, crédito no valor do imposto pago pela sociedade em relação àquela determinada parcela de lucros distribuídos. Esse método, portanto, também concentra seus benefícios na pessoa do sócio, de forma que, apesar de mitigar os efeitos da dupla tributação do lucro das sociedades, sob perspectiva econômica, é pouco eficaz.

Henry Tilbery aponta que a problemática decorrente desse método é a possível existência de crédito do imposto em valor superior à obrigação tributária dos sócios. Nesse caso, o autor sugere a previsão ou não de restituição do Imposto sobre a Renda referente ao crédito em excesso $^{128}$. Adicionalmente, poderia haver a possibilidade de utilização desse crédito em exercícios futuros.

O método da dedução dos dividendos pagos, também considerado um método de integração parcial, consiste basicamente na caracterização dos dividendos pagos como despesa dedutível da pessoa jurídica. Ou seja, esse método imputa aos dividendos, no nível da pessoa jurídica pagadora, tratamento tributário idêntico àquele concedido às remunerações de financiamentos por meio de capital de terceiros, i.e., juros de empréstimos, eliminando a vantagem competitiva deste último.

O benefício concedido por esse método, portanto, consiste na eliminação do tratamento tributário vantajoso comumente concedido aos financiamentos de terceiros, tornando o financiamento por meio de capital próprio, sob ponto de vista fiscal, tão atraente quanto aquele realizado com capital de terceiros. Nesse sentido, Henry Tilbery resume:

"Uma vantagem importante deste método consiste no tratamento dos
dividendos, como despesa dedutível, da mesma forma como juros sobre
empréstimos, de modo que terminaria a distorção do sistema atual, que
torna o financiamento com recursos de terceiros do ponto de vista fiscal
mais atraente do que o financiamento com capital próprio."

O método da dedução dos dividendos pagos, diferentemente dos dois últimos métodos analisados, concentra seus benefícios nas sociedades, mantendo a carga tributária

\footnotetext{
${ }^{128}$ TILBERY, Henry. op. cit., p. 44.
} 
no nível dos seus sócios, o que pode tornar o investimento menos atraente. Por outro lado, conforme argumentado por Heleno Taveira Tôrres, a dedutibilidade dos dividendos pode ser vista pelas sociedades como um incentivo ao seu pagamento ${ }^{129}$, o que é uma vantagem para sócios minoritários, que não possuem poder decisório em relação a essa distribuição.

Ainda em relação a esse método, é importante ressaltar que a dupla tributação dos lucros não é completamente eliminada, uma vez que, nos casos de retenção de lucros como forma de autofinanciamento ou para a formação de reserva, por exemplo, remanesce a tributação no nível da sociedade.

Conforme será visto oportunamente, esse método corresponde, de certa forma, à figura dos juros sobre o capital próprio (doravante denominado JSCP) instituída expressamente no sistema jurídico brasileiro em 1995.

O quinto e último método de integração parcial é o método da retenção, que considera o valor do imposto pago pela sociedade como uma antecipação do Imposto sobre a Renda devido pelos sócios. À pessoa jurídica, fonte pagadora dos dividendos, é atribuída a responsabilidade pela retenção do imposto devido pelos seus sócios. Segundo esse método, os sócios devem oferecer o valor bruto dos dividendos à tributação e deduzir do valor devido a parcela do imposto já recolhida pela sociedade.

O seu efeito, portanto, é o mesmo percebido pelos métodos de integração parcial do crédito dos dividendos recebidos e da exclusão dos dividendos recebidos. Isso porque, ao considerar o imposto pago pela sociedade como imposto devido pelo sócio e retido pela pessoa jurídica como antecipação, ressalvando as possíveis diferenças de alíquotas aplicáveis à sociedade e aos sócios, o efeito econômico da operação como um todo é o mesmo daquele obtido ao se conceder ao sócio o crédito do imposto pago pela sociedade ou a exclusão dos dividendos da sua base tributável.

É importante notar que esses métodos de integração parcial possuem diferenças quando a análise é feita isoladamente, ao invés de analisar a operação de distribuição de dividendos como um todo, englobando a pessoa jurídica pagadora e os seus sócios. Apesar de possuírem carga tributária total e efetiva muito similar, os métodos de integração parcial oferecem, cada um à sua maneira, vantagens e desvantagens para a pessoa jurídica pagadora e para os seus sócios.

\footnotetext{
${ }^{129}$ TÔRRES, Heleno Taveira. Juros sobre capital próprio - autonomia privada nos investimentos societários e suas implicações em matéria tributária, cit., v. 4, p. 364.
} 
Exceto pelo método da dedução dos dividendos pagos, todos os demais métodos de integração parcial concentram seus impactos tributários na pessoa do sócio, que poderá, conforme o método aplicado, tributar os dividendos a uma alíquota diferenciada, excluí-los da sua base tributável ou creditar-se do imposto pago pela sociedade em relação àqueles dividendos.

O método da dedução dos dividendos pagos beneficia diretamente a pessoa jurídica pagadora que, ao calcular o imposto devido, poderá considerar os dividendos pagos como despesa dedutível, reduzindo, portanto, a base de cálculo do Imposto sobre a Renda. Os sócios, por sua vez, deverão considerar os dividendos recebidos como rendimento tributável, sujeitando-os normalmente à tributação por esse imposto.

Resta, ainda, analisar os métodos de integração total, os quais, diferentemente dos métodos de integração parcial, visam não apenas à eliminação ou mitigação dos efeitos da dupla tributação dos rendimentos distribuídos sob a forma de dividendos, mas também à redução desse mesmo efeito sobre aqueles lucros auferidos pela sociedade e ainda não distribuídos aos seus sócios.

São dois os métodos de integração total incluídos no trabalho de Henry Tilbery. O primeiro deles determina a eliminação da tributação das pessoas jurídicas em separado e a conseqüente tributação, na pessoa dos sócios, dos dividendos distribuídos e dos ganhos de capital eventualmente obtidos. Pelo sistema de tributação norte-americano, nesse método, os lucros auferidos pela sociedade e ainda não distribuídos aos seus sócios seriam tributados no nível da pessoa física, sob a forma de ganho de capital, quando da eventual alienação da participação societária correspondente.

Ademais, ainda que a tributação no nível da pessoa jurídica seja eliminada, especificamente em relação aos lucros retidos, a tributação pelo Imposto sobre a Renda no nível dos sócios se dá apenas no momento da alienação da participação societária correspondente.

Por fim, resta analisarmos o segundo e último método de integração total, o método da distribuição de lucros e atribuição dos lucros retidos, também conhecido como Plano Carter $^{130}$. A principal diferença e novidade desse método decorre da possibilidade de atribuir aos sócios, para fins fiscais, os lucros retidos pela sociedade, possibilitando a sua

\footnotetext{
${ }^{130}$ A denominação decorre do fato de esse método ter sido proposto em 1966 no Canadá, por meio de relatório da Comissão Real sobre Tributação, comissão esta presidida por M. Kenneth Carter.
} 
tributação a partir dessa atribuição. Assim, não apenas os lucros efetivamente distribuídos pela sociedade seriam tributados no nível dos sócios, mas também os lucros retidos e a eles atribuídos pela sociedade.

No nível dos sócios, segundo esse método, deve-se oferecer à tributação o valor total dos lucros distribuídos e dos lucros retidos a eles atribuídos ${ }^{131}$, adicionados do valor do imposto recolhido pela sociedade ${ }^{132}$, que deverá ser posteriormente abatido do valor total da renda tributável. As regras previstas no Plano Carter possuem diversas especificidades, que implicam conseqüências diretas para a sociedade e para os seus sócios. Diante do objeto deste trabalho, limitamo-nos a definir o seu conceito básico. Contudo, George F. Break publicou um artigo no National Tax Journal, no qual ele analisa detalhadamente as regras do Plano Carter ${ }^{133}$.

Segundo Charles McLure Jr., apesar das significativas vantagens econômicas decorrentes dos métodos de integração total, sob o ponto de vista prático, sua implementação apresenta muitas dificuldades. Por esse motivo, em detalhado artigo sobre o assunto, esse autor conclui que, apesar de não concederem todos os benefícios econômicos dos métodos de integração total, a adoção de métodos de integração parcial pode ser mais benéfica sob o ponto de vista administrativo ${ }^{134}$.

\section{A solução do Direito Positivo Brasileiro para a eliminação da dupla tributação sobre os lucros das sociedades. Os métodos de avaliação de investimentos permanentes e as regras tributárias aplicáveis à distribuição de dividendos}

No Sistema Tributário Brasileiro, as pessoas jurídicas, por opção ou por determinação legal, são tributadas pelo Imposto sobre a Renda segundo um dos seguintes regimes: (i) lucro real; ou (ii) lucro presumido ${ }^{135}$.

\footnotetext{
${ }^{131}$ Quanto aos lucros retidos e tributados no momento da sua atribuição aos sócios, o Plano Carter prevê a isenção do Imposto sobre a Renda no momento da sua distribuição.

${ }^{132}$ No caso dos lucros efetivamente distribuídos, há previsão de retenção do imposto na fonte no momento do pagamento.

${ }^{133}$ BREAK, George F. op. cit., p. 39-56.

${ }^{134}$ McLURE JR., Charles. A status report on tax integration in the United States. National Tax Journal (pre1986), Washington, v. 31, n. 4, p. 313, dez. 1978.

${ }^{135}$ Para os fins deste trabalho, será descartada a análise das regras aplicáveis ao regime do lucro arbitrado pelo fato de ele existir apenas subsidiariamente aos outros dois. É, regra geral, forma de apuração da base de cálculo do Imposto sobre a Renda aplicável às hipóteses em que o contribuinte não cumpre as obrigações relativas à determinação do lucro real ou presumido (Lei no 8.981/95, artigo 47, Lei $n^{\circ} 9.430 / 96$, artigo $1^{\circ}$, e
} 
Dentre outras, a principal diferença entre esses regimes reside na forma de apuração da base de cálculo do Imposto sobre a Renda.

O regime do lucro real, como o próprio nome sugere, é aquele em que a base de cálculo do Imposto sobre a Renda é o efetivo lucro auferido pela sociedade, i.e., o lucro real. O lucro real é, por definição, o lucro líquido do período de apuração, obtido de acordo com as normas analisadas no item 2.2.2. do Capítulo I deste trabalho e devidamente ajustado pelas adições, exclusões ou compensações previstas na legislação tributária ${ }^{136}$.

É exatamente em virtude da necessidade de ajuste do lucro líquido do exercício que decorre a complexidade desse regime, quando comparado com o do lucro presumido.

Regra geral, segundo esse método, devem ser adicionados ao lucro líquido (i) os valores deduzidos na apuração desse lucro que, de acordo com a legislação tributária, não são dedutíveis na determinação do lucro real, por exemplo, os resultados negativos de equivalência patrimonial e os custos e despesas não dedutíveis; (ii) os valores não incluídos na apuração desse lucro e que, de acordo com a legislação tributária, devem ser computados na determinação do lucro real, por exemplo, os ajustes decorrentes da aplicação dos métodos dos preços de transferência ${ }^{137}$.

Por sua vez, poderão ser excluídos do lucro líquido (i) os valores cuja dedução seja autorizada pela legislação tributária e que não tenham sido computados na sua apuração; (ii) os valores incluídos na sua apuração que, de acordo com a legislação tributária, não são computados no lucro real, como é o caso dos resultados positivos de equivalência patrimonial e dos dividendos ${ }^{138}$.

Ainda, na apuração do lucro real poderão ser compensados, à opção do contribuinte, os prejuízos fiscais de períodos de apuração anteriores, desde que observado o limite máximo de 30\% (trinta por cento) do lucro líquido já ajustado pelas adições e

Regulamento do Imposto sobre Renda - Decreto $\mathrm{n}^{\circ}$ 3.000/99, artigo 530). Especialmente em relação às microempresas e empresas de pequeno porte, vale mencionar que, nos termos da Lei Complementar $n^{\circ}$ 123/06, o recolhimento do Imposto sobre a Renda é realizado por meio de regime simplificado de tributação, denominado Simples Nacional, que abrange também a Contribuição Social sobre o Lucro Líquido, Imposto sobre Produtos Industrializados, Contribuição para o Financiamento da Seguridade Social, Contribuição para o PIS/PASEP, Imposto Estadual sobre Operações Relativas à Circulação de Mercadorias e Sobre Prestações de Serviços de Transporte Interestadual e Intermunicipal e de Comunicação e Imposto Municipal sobre Serviços de Qualquer Natureza.

${ }^{136}$ Decreto-Lei $n^{\circ} 1.598 / 77$, artigo $6^{\circ}$, Lei $\mathrm{n}^{\circ} 8.981 / 95$, artigo 37 , parágrafo $1^{\circ}$, e Regulamento do Imposto sobre Renda - Decreto $\mathrm{n}^{\circ} 3.000 / 99$, artigo 247.

${ }^{137}$ Decreto-Lei $\mathrm{n}^{\mathrm{o}} 1.598 / 77$, artigo $6^{\circ}$, parágrafo $2^{\circ}$, e Regulamento do Imposto sobre Renda - Decreto $\mathrm{n}^{\mathrm{o}}$ 3.000/99, artigo 249.

${ }^{138}$ Decreto-Lei $\mathrm{n}^{\mathrm{o}} 1.598 / 77$, artigo $6^{\circ}$, parágrafo $3^{\circ}$, e Regulamento do Imposto sobre Renda - Decreto $\mathrm{n}^{\mathrm{o}}$ 3.000/99, artigo 250. 
exclusões acima listadas. Para esses fins, o prejuízo compensável é aquele apurado na demonstração do lucro real de períodos anteriores e registrado no Livro de Apuração do Lucro Real - LALUR ${ }^{139}$.

Segundo o regime do lucro presumido, a base de cálculo do Imposto sobre a Renda equivale, em termos gerais, ao valor estimado de lucro auferido pela sociedade. Seu valor é obtido mediante a aplicação de determinado percentual, que varia de 1,6\% (um inteiro e seis décimos por cento) a $32 \%$ (trinta e dois por cento), sobre a receita bruta auferida $^{140}$.

O percentual geral aplicável sobre a receita bruta da sociedade é de $8 \%$ (oito por cento). Entretanto, existem exceções previstas em função do tipo de atividade exercida, as quais, na prática, são aplicadas com maior freqüência do que a regra geral dos $8 \%$ (oito por cento). Resumidamente, são elas: (i) $32 \%$ (trinta e dois por cento) para os serviços em geral $^{141}$, atividades de intermediação de negócios e administração e locação ou cessão de bens e direitos; (ii) 16\% (dezesseis por cento) para os serviços de transporte em geral; (iii) $1,6 \%$ (um vírgula seis por cento) para a atividade de revenda de combustíveis ${ }^{142}$.

Ao resultado da aplicação desses percentuais sobre a receita bruta das sociedades, deverão ser acrescidos alguns valores especificamente previstos na legislação. Como exemplo, podemos citar: (i) ganhos de capital, rendimentos e ganhos líquidos auferidos em aplicações financeiras; (ii) variações monetárias ativas; (iii) demais resultados positivos obtidos pela pessoa jurídica, inclusive os juros recebidos como remuneração do capital próprio e os rendimentos auferidos nas operações de mútuo realizadas entre pessoas jurídicas ligadas $^{143}$.

Uma vez apurada a base de cálculo do Imposto sobre Renda de acordo com as regras acima, independentemente do regime de tributação adotado pela sociedade, o valor do imposto devido será calculado mediante a aplicação da alíquota de $15 \%$ (quinze por cento). A parcela do lucro tributável, seja ele real ou presumido, que exceder ao resultado

\footnotetext{
${ }^{139}$ Decreto-Lei $\mathrm{n}^{\mathrm{o}} 1.598 / 77$, artigo $6^{\circ}$, parágrafo $3^{\circ}$, Lei $\mathrm{n}^{\mathrm{o}} 9.065 / 95$, artigo 15 , parágrafo único, e Regulamento do Imposto sobre Renda - Decreto $\mathrm{n}^{\circ} 3.000 / 99$, artigo 250.

${ }^{140}$ Lei $n^{\circ} 9.249 / 95$, artigo 15 , Lei $n^{\circ} 9.430 / 96$, artigos $1^{\circ}$ e 25 , inciso I, e Regulamento do Imposto sobre Renda - Decreto n $3.000 / 99$, artigo 518.

${ }^{141}$ Excepcionalmente, conforme prevê o artigo 40 da Lei $n^{\circ} 9.250 / 95$, a base de cálculo do Imposto sobre a Renda das pessoas jurídicas prestadoras de serviço cuja receita bruta anual é de até $\mathrm{R} \$ 120.000,00$ (cento e vinte mil reais) será determinada mediante a aplicação da alíquota de $16 \%$ sobre a receita bruta auferida.

${ }^{142}$ Lei $\mathrm{n}^{\circ}$ 9.249/95, artigo 15 , parágrafo $1^{\circ}$, e Regulamento do Imposto sobre Renda - Decreto $\mathrm{n}^{\circ} 3.000 / 99$, artigo 519 , parágrafo $1^{\circ}$.

${ }^{143}$ Lei $n^{\circ}$ 9.430/96, artigo 25, inciso II, e Regulamento do Imposto sobre Renda - Decreto ${ }^{\circ}$ 3.000/99, artigo 521.
} 
da multiplicação de $\mathrm{R} \$ 20.000,00$ (vinte mil reais) pelo número de meses do respectivo período de apuração, está sujeita à incidência do adicional de 10\% (dez por cento) do Imposto sobre a Renda ${ }^{144}$.

É em decorrência desse adicional de $10 \%$ (dez por cento) e da incidência da Contribuição Social sobre o Lucro Líquido à alíquota de $9 \%$ (nove por cento) sobre a mesma base de cálculo do Imposto sobre a Renda, que, na prática, costuma-se falar que o Imposto sobre a Renda devido pelas pessoas jurídicas deve ser calculado à alíquota de $34 \%$ (trinta e quatro por cento).

Por fim, vale ressaltar que as pessoas jurídicas não podem escolher livremente qual desses regimes adotar para fins de cálculo do Imposto sobre a Renda. O principal critério que divide os contribuintes entre os dois grandes grupos de regime de tributação desse imposto é o volume da receita bruta auferida no ano-calendário anterior.

Nos termos do artigo 14, inciso I, da Lei $\mathrm{n}^{\circ}$ 9.718/98, alterado pelo artigo 46 da Lei $n^{\circ} 10.637 / 02$, estão obrigadas à apuração do Imposto sobre a Renda com base no regime do lucro real as pessoas jurídicas cuja receita bruta total, no ano-calendário anterior, tenha sido superior a $\mathrm{R} \$ 48.000 .000,00$ (quarenta e oito milhões de reais) ou, nos casos em que a sociedade existir há menos de um ano, a $\mathrm{R} \$ 4.000 .000,00$ (quatro milhões de reais) multiplicado pelo número de meses de atividade do ano-calendário anterior.

Além desse critério de seleção, o mesmo artigo 14 taxativamente lista as pessoas jurídicas que estão obrigadas a apurar o Imposto sobre a Renda devido com base no regime do lucro real. São elas:

(i) pessoas jurídicas que exercem atividades típicas de bancos comerciais, bancos de investimento e de desenvolvimento, caixas econômicas, sociedades de crédito, financiamento, investimento, crédito imobiliário, títulos e valores mobiliários, empresas de arrendamento mercantil, cooperativas de crédito, empresas de seguro privado e de capitalização e entidades de previdência privada aberta;

(ii) pessoas jurídicas que auferirem lucros, rendimentos ou ganhos de capital oriundos do exterior;

\footnotetext{
${ }^{144}$ Lei $\mathrm{n}^{\circ}$ 9.249/95, artigo $3^{\circ}$, Lei $\mathrm{n}^{\mathrm{o}} 9.249 / 95$, artigo $3^{\circ}$, parágrafo $1^{\circ}$, Lei $\mathrm{n}^{\circ} 9.430 / 96$, artigo $4^{\circ}$, e Regulamento do Imposto sobre Renda - Decreto n ${ }^{\circ} 3.000 / 99$, artigos 541 e 542.
} 
(iii) pessoas jurídicas beneficiárias de isenções ou reduções do Imposto sobre a Renda;

(iv) pessoas jurídicas que exploram as atividades de prestação cumulativa e contínua de serviços de assessoria creditícia, mercadológica, gestão de crédito, seleção e riscos, administração de contas a pagar e a receber, compras de direitos creditórios resultantes de vendas mercantis a prazo ou de prestação de serviços (factoring).

\subsection{A avaliação de investimentos permanentes: o método do custo versus o método da equivalência patrimonial ${ }^{145}$}

As avaliações de investimentos permanentes em outras sociedades podem ser realizadas, nas pessoas jurídicas ${ }^{146}$, de duas diferentes formas ${ }^{147}$ : por meio do método do custo ou do método da equivalência patrimonial.

Segundo o método do custo ${ }^{148}$, o investimento deverá ser registrado no ativo da investidora pelo seu valor de aquisição, diminuído de provisão para perdas prováveis, nos casos em que essa perda estiver comprovada como permanente ${ }^{149}$.

Para esses fins, o conceito de custo de aquisição é definido por Bulhões Pedreira como a "quantidade de capital financeiro aplicado pela sociedade empresária para adquirir o ativo" ${ }^{, 150}$. Sob perspectiva ainda mais prática e objetiva, Sérgio de Iudícibus, Eliseu Martins e Ernesto Rubens Gelbcke definem custo de aquisição como "o valor

\footnotetext{
${ }^{145}$ Regras específicas sobre a avaliação de investimentos por companhias abertas, instituições financeiras e demais instituições autorizadas a funcionar pelo Banco Central do Brasil podem ser encontradas nas Instruções da Comissão de Valores Mobiliários nos. 247/96 e 285/98 e Portaria do Ministério da Fazenda ${ }^{\circ}$ $319 / 78$.

${ }^{146}$ Nos termos do artigo 179, inciso III, da Lei das Sociedades Anônimas - Lei n ${ }^{\circ}$ 6.404/76, as participações permanentes em outras sociedades devem ser registradas em conta do ativo denominada investimentos.

${ }^{147}$ Artigo 183, inciso III, da Lei das Sociedades Anônimas - Lei no 6.404/76.

${ }^{148}$ Bulhões Pedreira, em sua obra "Finanças e demonstrações financeiras da companhia", lista as três justificativas para a adoção do método do custo, quais sejam: (i) a identificação do valor efetivamente gasto na aquisição do investimento; (ii) maior precisão e objetividade para identificação do custo de aquisição, quando comparado com a identificação do valor atualizado do investimento; (iii) a adoção de critério baseado no valor atualizado do investimento exige sua reavaliação constante. A despeito dessas justificativas, o autor critica o método do custo, apontando que sua objetividade está condicionada à aquisição de ativos em condições normais de mercado.

${ }^{149}$ Artigo 183, inciso III, da Lei das Sociedades Anônimas - Lei no 6.404/76.

${ }^{150}$ PEDREIRA, José Luiz Bulhões. op. cit., p. 338.
} 
efetivamente despendido na transação por subscrição relativa a aumento de capital, ou ainda pela compra de ações de terceiros" ${ }^{\prime 151}$.

Para a determinação do custo do investimento segundo esse método, o DecretoLei $\mathrm{n}^{\mathrm{o}} 2.072 / 83$, em seu artigo $2^{\mathrm{o}}{ }^{152}$, determina expressamente que os lucros ou dividendos recebidos em decorrência de participação societária adquirida até seis meses antes da data da respectiva percepção devem ser registrados pelo contribuinte como diminuição do valor do custo de aquisição ${ }^{153}$.

Por sua vez, segundo o método da equivalência patrimonial, o valor do investimento será determinado mediante a aplicação da porcentagem de participação no capital social da investida sobre o seu valor de patrimônio líquido ${ }^{154}$. Para tanto, o artigo 248 da Lei das Sociedades Anônimas - Lei no 6.404/76 - determina que, no valor de patrimônio líquido da investida, não devem ser computados os resultados não realizados decorrentes de negócios com a investidora ou com outras sociedades coligadas à investidora ou por ela controladas ${ }^{155}$.

Para esses fins, o artigo 243 da Lei das Sociedades Anônimas - Lei n 6.404/76 estabelece os conceitos de sociedades coligadas e controladas, respectivamente, como as sociedades nas quais (i) a investidora tem influência significativa; (ii) a controladora, diretamente ou por meio de outras controladas, é titular de direitos que lhe assegurem, de modo permanente, preponderância nas deliberações sociais e poder de eleger a maioria dos administradores. Nos termos desse mesmo artigo, há influência significativa quando a investidora, sem controlar a investida, detém ou exerce o poder de participar nas decisões sobre as suas políticas financeiras ou operacionais. Da mesma forma, a influência significativa é presumida quando a investidora, sem controlar a investida, é titular de $20 \%$ (vinte por cento) ou mais do seu capital votante.

Especialmente em relação à definição de sociedade coligada, é importante

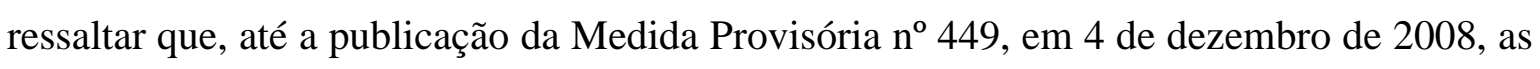
sociedades coligadas eram definidas como aquelas em que a investidora participa com $10 \%$

\footnotetext{
${ }^{151}$ IUDÍCIBUS, Sérgio de; MARTINS, Eliseu; GELBCKE, Ernesto Rubens. op. cit., p. 141.

${ }^{152}$ Regulamento do Imposto sobre a Renda - Decreto 3.000/99, artigo 380.

${ }^{153}$ A redução do custo de aquisição nesses termos não deve ser refletida nas contas de resultado na sociedade.

${ }^{154} \mathrm{O}$ valor de patrimônio líquido da investida, adotado para esses fins, deve ser aquele apurado em balanço patrimonial ou balancete de verificação levantado, com observância das normas da Lei das Sociedades Anônimas - Lei n 6.404/76, na mesma data, ou até 60 (sessenta) dias, no máximo, antes da data do balanço da investidora.

${ }^{155}$ Artigo 248, inciso I, da Lei das Sociedades Anônimas - Lei nº 6.404/76.
} 
(dez por cento) ou mais do capital social, mas não a controla. Em 12 de janeiro de 2009, essa Medida Provisória ainda estava pendente de aprovação pelo Congresso Nacional para conversão em lei.

Ainda em relação ao método da equivalência patrimonial, é importante mencionar que o valor do investimento deverá ser ajustado ao valor de patrimônio líquido da investida mediante lançamento da diferença a débito ou a crédito da conta de investimento ${ }^{156}$. Em outras palavras, as variações positivas ou negativas do valor do patrimônio líquido da investida deverão ser refletidas na investidora mediante alteração do valor registrado em conta do ativo, subgrupo investimento ${ }^{157}$. A contrapartida do ajuste do valor do investimento, seja em virtude de aumento ou redução no valor do patrimônio líquido da investida, deve ser expressamente excluída da determinação do lucro real ${ }^{158}$.

Quanto aos critérios de aplicação dos métodos de custo e de equivalência patrimonial, a principal diferença reside no nível de participação da investidora e na relevância do investimento. O método do custo de aquisição é destinado à avaliação de investimentos de menor porte, enquanto o método da equivalência patrimonial é utilizado na avaliação de investimentos de maior relevância ${ }^{159}$.

Segundo a redação do caput do artigo 248, vigente até 31 de dezembro de 2007, seriam avaliados pelo método da equivalência patrimonial apenas os investimentos em sociedades controladas e os investimentos relevantes em sociedades coligadas sobre cuja administração a investidora tinha influência, ou em que a investidora participasse com $20 \%$ (vinte por cento) ou mais do capital social. Para esses fins, o parágrafo único do artigo 247 da mesma lei determina o conceito de investimento relevante como aquele (i) cujo valor contábil é igual ou superior a $10 \%$ (dez por cento) do valor do patrimônio líquido da sociedade, em se tratando de investimentos individuais em sociedade coligada ou controlada; (ii) cujo valor contábil é igual ou superior a 15\% (quinze por cento) do valor do patrimônio líquido da sociedade, quando se tratar de um grupo de sociedades coligadas e controladas.

\footnotetext{
${ }^{156}$ Decreto-Lei n ${ }^{\mathrm{o}} 1.598 / 77$, artigo 22.

${ }^{157} \mathrm{Em}$ relação aos investimentos em sociedades com valor negativo do patrimônio líquido, a prática contábil mais adequada determina a redução do valor da conta investimento até zero, sem o registro de qualquer valor negativo, quando aplicável no caso concreto. Nesses casos, as eventuais alterações positivas desse investimento deverão levar em conta a perda total até então apresentada em relação àquele investimento e não apenas majorar o valor da conta investimento proporcionalmente. (IUDÍCIBUS, Sérgio de; MARTINS, Eliseu; GELBCKE, Ernesto Rubens. op. cit., p. 187).

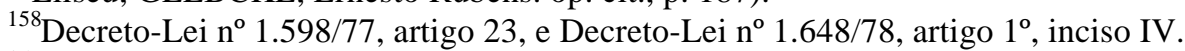

${ }^{159}$ IUDÍCIBUS, Sérgio de; MARTINS, Eliseu; GELBCKE, Ernesto Rubens. op. cit., p. 135.
} 
Em 28 de dezembro de 2007, foi publicada a Lei $n^{\circ} 11.638^{160}$ que, dentre outras previsões, alterou inúmeros artigos da Lei das Sociedades Anônimas - Lei no 6.404/76, com a intenção de adaptar as normas brasileiras de contabilidade às normas internacionais, conhecidas como International Financial Reporting Standards - IFRS. Uma das mudanças inseridas na Lei das Sociedades Anônimas - Lei no 6.404/76 - pela Lei n ${ }^{\circ} 11.638 / 07$ consiste na redefinição do critério de aplicação do método da equivalência patrimonial, mediante alteração da redação do caput do mencionado artigo 248.

Com redação vigente a partir de $1^{\circ}$ de janeiro de 2008, o caput do artigo 248 passou a determinar que um número maior de investimentos estivesse sujeito à avaliação pelo método da equivalência patrimonial. Isso porque a Lei $n^{\circ} 11.638 / 07$ excluiu a menção ao requisito da relevância do investimento, até então solicitado para a aplicação desse método e passou a exigir que também os investimentos em outras sociedades que fizessem parte de um mesmo grupo ou estivessem sob controle comum fossem avaliados pelo método da equivalência patrimonial.

Como se isso não bastasse, a Medida Provisória $n^{\circ}$ 449/08 foi publicada e trouxe nova redação para o caput do artigo 248 da Lei das Sociedades Anônimas - Lei $\mathrm{n}^{\circ}$ 6.404/76, que passou a incluir ainda mais investimentos na avaliação pelo método da equivalência patrimonial. Segundo a redação atualmente vigente desse artigo, estão sujeitos à avaliação pelo método da equivalência patrimonial todos os investimentos em sociedades coligadas e controladas e em outras sociedades que façam parte de um mesmo grupo ou estejam sob controle comum.

A despeito de a Lei no 11.638/07 e a Medida Provisória n $^{\circ}$ 449/08 terem alterado o conceito de sociedade coligada e terem aumentado o âmbito de aplicação do método da equivalência patrimonial, a própria Medida Provisória $n^{\circ} 449 / 08$ prevê que, caso essas alterações modifiquem o critério de reconhecimento de receitas, custos e despesas computados na apuração do lucro líquido do exercício, estas não terão efeitos para fins tributários, para os quais os métodos e critérios contábeis vigentes em 31 de dezembro de 2007 ainda são válidos ${ }^{161}$.

\footnotetext{
${ }^{160}$ Em vigor desde $1^{\circ}$ de janeiro de 2008.

${ }^{161}$ Artigo 16 da Medida Provisória no 449/08.
} 


\subsection{Distribuição de dividendos: a contabilização e os efeitos tributários decorrentes da remuneração pelo capital próprio investido}

A contabilização dos dividendos e os efeitos tributários decorrentes do seu pagamento devem ser analisados sob duas perspectivas: a da fonte pagadora, i.e., a sociedade investida, e a dos seus sócios, beneficiários dos rendimentos.

Do ponto de vista da fonte pagadora, os dividendos podem ser contabilizados como uma provisão (dividendos propostos) ou como uma obrigação exigível (dividendos a pagar). No primeiro caso, a distribuição de dividendos ainda não foi aprovada pela assembléia e existe apenas como uma proposta da administração da sociedade ${ }^{162}$. Enquanto o valor dos dividendos a serem distribuídos não for aprovado pela assembléia, o valor proposto pela administração deverá ser contabilizado como provisão.

Uma vez aprovada a distribuição dos dividendos e o seu valor ${ }^{163}$, o seu registro deve ser transferido para a conta denominada dividendos a pagar, constante do passivo circulante da sociedade. Na prática, apesar de essa conta representar valores devidos aos sócios, muitas vezes o valor dos dividendos já foi até mesmo creditado em seu benefício ${ }^{164}$.

A legislação vigente não prevê qualquer tipo de implicação benéfica para a sociedade em relação à distribuição de dividendos e esse é o aspecto que pode tornar o financiamento da sociedade por meio de capital de terceiros mais atraente. Isso porque as despesas com o pagamento de juros remuneratórios de empréstimos concedidos à sociedade são dedutíveis para fins de cálculo do Imposto sobre a Renda e da Contribuição Social sobre o Lucro Líquido, o que não ocorre em relação ao pagamento de dividendos.

Conforme será analisado a seguir, como forma de evitar a dupla tributação dos lucros das sociedades, a falta de previsão de dedutibilidade dos dividendos distribuídos é, de certa forma, compensada por meio da isenção do Imposto sobre a Renda incidente no nível dos sócios.

\footnotetext{
${ }^{162}$ Segundo o artigo 176, parágrafo $3^{\circ}$, da Lei das Sociedades Anônimas - Lei n ${ }^{\circ}$ 6.404/76, as demonstrações financeiras deverão registrar a destinação dos lucros proposta pelos órgãos da administração, sujeitas à aprovação pela assembléia.

${ }^{163}$ Nos termos do artigo 134, parágrafo $4^{\circ}$, da Lei das Sociedades Anônimas - Lei n ${ }^{\circ}$ 6.404/76, na hipótese de a assembléia aprovar as demonstrações financeiras com modificação do montante do lucro do exercício ou do valor das obrigações da companhia, os administradores deverão republicar as demonstrações, devidamente retificadas. Ainda, se a distribuição dos lucros proposta pelos órgãos de administração não for aprovada, as modificações introduzidas nas demonstrações financeiras também deverão constar da ata da assembléia.

${ }^{164}$ Por tudo, IUDÍCIBUS, Sérgio de; MARTINS, Eliseu; GELBCKE, Ernesto Rubens. op. cit., p. 245 e 271.
} 
Quanto aos sócios, nos termos dos artigos 11 e 19, inciso II, do Decreto-Lei $\mathrm{n}^{\circ}$

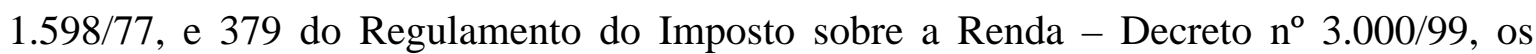
lucros e dividendos recebidos de outra pessoa jurídica devem, regra geral, integrar o lucro operacional da sociedade investidora, entendido como o resultado das atividades, principais ou acessórias, que constituam objeto da pessoa jurídica ${ }^{165}$.

Isso significa que, enquanto a distribuição dos dividendos não for aprovada pela assembléia e estiver lançada como provisão na sociedade investida, a sociedade investidora deverá debitar seu valor na conta de dividendos a receber e, com base no regime de competência, creditar a conta de receita. Após a deliberação da assembléia sobre a distribuição dos dividendos, deverá ser verificado se o valor proposto para a distribuição foi integralmente aprovado pela assembléia. Eventuais diferenças entre os valores propostos deverão ser refletidas na sociedade investidora mediante lançamento de receita complementar ou reversão de parte da receita já lançada ${ }^{166}$.

Note-se, entretanto, que essa regra vale apenas para os dividendos recebidos em relação a investimentos avaliados pelo método do custo de aquisição. Os dividendos recebidos em decorrência de investimentos avaliados pelo método da equivalência patrimonial deverão ser registrados como diminuição do valor do investimento, segundo o artigo 22, parágrafo único, do Decreto-Lei $1.598 / 77^{167}$. Nada mais lógico, tendo em vista que, conforme visto anteriormente, as alterações positivas no patrimônio líquido da investida, e.g., lucros do exercício ou lucros acumulados, já foram refletidas na mesma conta de investimento.

Independentemente de o registro dos dividendos nas sociedades investidoras se dar a débito em conta de receita ou a crédito na conta de investimento, sob a perspectiva dos sócios, esses lançamentos contábeis não devem incorrer em qualquer reflexo nas contas de resultado ${ }^{168}$.

\footnotetext{
${ }^{165}$ Decreto-Lei no $1.598 / 77$, artigo 11.

${ }^{166}$ Por tudo, IUDÍCIBUS, Sérgio de; MARTINS, Eliseu; GELBCKE, Ernesto Rubens. op. cit., p. 142-143.

${ }^{167}$ Parágrafo $1^{\mathrm{o}}$ do artigo 388 do Regulamento do Imposto sobre a Renda - Decreto ${ }^{\circ}$ 3.000/99.

${ }^{168}$ Especificamente em relação aos investimentos avaliados pelo método da equivalência patrimonial, quando os lucros ou dividendos forem apurados em balanço levantado posteriormente ao último balanço da investidora, i.e., quando são distribuídos lucros ou dividendos antes que estes tenham sido integrados ao valor do investimento e aos resultados da investidora, os lucros ou dividendos deverão ser creditados à conta de resultados da investidora e, regra geral, não serão computados na determinação do lucro real, conforme será analisado a seguir no presente trabalho. Se a avaliação subseqüente for baseada em balanço ou balancete de data anterior à da distribuição, o patrimônio líquido da coligada ou controlada deverá ser ajustado, com a exclusão do valor total distribuído (parágrafos $2^{\circ}$ e $3^{\circ}$ do artigo 388 do Regulamento do Imposto sobre a Renda - Decreto nº 3.000/99).
} 
Sob o ponto de vista tributário, a legislação vigente prevê que os dividendos distribuídos deverão ser excluídos do lucro líquido para efeito de determinar o lucro real, nas hipóteses em que estiverem sujeitos à tributação nas sociedades que os distribuíram ${ }^{169}$. Em outras palavras, esses rendimentos não estarão sujeitos à tributação pelo Imposto sobre a Renda quando estiverem sujeitos à tributação por esse imposto nas sociedades de que provêm ${ }^{170}$. Essa regra pode ser vista como uma tentativa de se evitar a dupla tributação dos lucros auferidos em relação a investimentos societários, conforme exposto acima, no item 1 deste Capítulo.

A despeito de existir previsão específica de exclusão de lucros e dividendos do lucro real em relação aos casos em que esses rendimentos estão sujeitos à tributação nas sociedades de que provêm, essa regra perdeu seu campo de aplicação diante da previsão legal de isenção do Imposto sobre a Renda incidente sobre lucros ou dividendos, calculados com base nos resultados apurados a partir de janeiro do ano-calendário de 1996 e distribuídos a sócios, pessoas físicas ou jurídicas, residentes no Brasil ou no exterior, conforme artigo 10 da Lei $\mathrm{n}^{\circ} 9.249 / 95^{171}$.

É importante ressaltar que a redação desse artigo prevê não apenas a exclusão da tributação no nível da investidora, mas também no momento do pagamento dos rendimentos por meio de retenção do Imposto sobre a Renda na fonte.

Quanto ao tratamento tributário dos dividendos, vigora, portanto, um sistema de plena integração, uma vez que os lucros auferidos são tributados apenas no nível das sociedades. Heleno Taveira Tôrres confirma esse entendimento, ao afirmar que "como no nosso sistema de tributação dos atos de distribuição dos lucros ou dividendos não há incidência, pelo art. 10, da Lei $n^{o}$ 9.249/95, bem como nos atos de percepção pelo acionista ou quotista, confirma-se uma perfeita neutralidade fiscal às distribuições de

\footnotetext{
${ }^{169}$ Decreto-Lei no 5.844/43, artigo 43, parágrafo 2º alínea “c”, Lei no 3.470/58, artigo 70, e Regulamento do Imposto sobre a Renda - Decreto n $3.000 / 99$, artigo 379, parágrafo $1^{\circ}$.

${ }^{170}$ Nos termos do Ato Declaratório Normativo do Coordenador do Sistema de Tributação (COSIT) n $n^{\circ}$ 5/74, para fins de aplicação dessa exclusão, "não se distinguem os lucros e dividendos que tenham sido tributados, dos que tenham gozado de isenção tributária, tenha sido esse benefício concedido em caráter geral ou especial". Exceção a essa regra são os lucros ou dividendos auferidos após a alienação ou liquidação de investimento avaliado pelo método de equivalência patrimonial, desde que tenham sido computados na determinação do ganho ou perda de capital (Decreto no 3.000/99, artigo 379, parágrafo $2^{\circ}$ ).

171“"Artigo 10. Os lucros ou dividendos calculados com base nos resultados apurados a partir do mês de janeiro de 1996, pagos ou creditados pelas pessoas jurídicas tributadas com base no lucro real, presumido ou arbitrado, não ficarão sujeitos à incidência do imposto de renda na fonte, nem integrarão a base de cálculo do imposto de renda do beneficiário, pessoa física ou jurídica, domiciliado no País ou no exterior."
} 
lucros e adoção ao modelo de integração total"172. Da mesma forma, Pedro Malan, Ministro da Fazenda que assinou a Exposição de Motivos do projeto de lei que foi posteriormente convertido na Lei $n^{\circ} 9.249 / 95$, afirma que a isenção em questão permitiu a "completa integração entre pessoa física e pessoa jurídica" $"$ ".

Em relação aos lucros apurados em período anterior ao exercício de 1996, o regime tributário aplicável, sob a perspectiva dos sócios, não é uniforme e possui especificidades em função do momento em que se deu a geração dos lucros distribuídos, do regime de tributação adotado pela sociedade pagadora e da qualificação do seu beneficiário.

A despeito de existirem diferenças entre as regras aplicáveis à tributação dos dividendos distribuídos por pessoas jurídicas sujeitas à apuração do lucro presumido e aquelas sujeitas à apuração do lucro real, existe uma característica específica que lhes é comum: a utilização do mecanismo de retenção na fonte do Imposto sobre a Renda no momento do pagamento dos dividendos.

A seguir, comentamos brevemente as regras aplicáveis, dividindo-as em dois grandes grupos: lucros gerados por sociedades sujeitas à tributação pelo Imposto sobre a Renda com base (i) no lucro real; (ii) no lucro presumido. O resumo que segue não pretende esgotar todas as regras existentes sobre a distribuição de dividendos, mas apenas apontar as mais recentes e relevantes para o desenvolvimento deste trabalho.

O primeiro período destacado pela legislação em relação aos lucros auferidos por sociedades tributadas com base no regime de lucro real é aquele compreendido entre os anos-calendário de 1994 e 1995.

Quanto aos dividendos pagos ou creditados aos sócios em decorrência de lucros gerados sob essas condições, existe previsão de retenção na fonte do Imposto sobre a Renda à alíquota de $15 \%$ (quinze por cento) ${ }^{174}$. É importante notar que o fato gerador do Imposto sobre a Renda incidente sobre aqueles lucros é o momento da sua distribuição, de forma que, mesmo com a publicação da Lei $n^{\circ} 9.249 / 95$, esses lucros, se ainda existentes no balanço de determinada sociedade, deverão ser tributados quando distribuídos.

\footnotetext{
${ }^{172}$ TÔRRES, Heleno Taveira. Juros sobre capital próprio - autonomia privada nos investimentos societários e suas implicações em matéria tributária, cit., v. 4, p. 366-367.

${ }^{173}$ Exposição de Motivos no $325 / 95$.

${ }^{174}$ Lei $\mathrm{n}^{\circ} 8.849 / 94$, artigo $2^{\circ}$, Lei $\mathrm{n}^{\circ} 9.064 / 95$, artigo $1^{\circ}$, e Regulamento do Imposto sobre a Renda - Decreto $\mathrm{n}^{\circ} 3.000 / 99$, artigo 655 .
} 
No caso de sócios pessoas físicas, o valor do Imposto sobre a Renda retido na fonte deve ser deduzido do imposto devido na declaração de ajuste anual. Quanto aos sócios pessoas jurídicas sujeitas à tributação com base no regime do lucro real, o Imposto sobre a Renda retido na fonte deve ser considerado como antecipação do imposto devido. Nos demais casos, e.g., pessoas jurídicas tributadas com base no lucro presumido, o Imposto sobre a Renda retido à alíquota de $15 \%$ (quinze por cento) deve ser considerado definitivo $^{175}$.

A aplicação da tributação na fonte nos termos acima fica prejudicada caso os sócios decidam utilizar esses rendimentos para subscrição de aumento de capital social da investida $^{176}$. Entretanto, a tributação será preservada nas hipóteses em que a investida, nos cinco anos subseqüentes ${ }^{177}$ ou anteriores ${ }^{178}$ à data da incorporação de lucros ao seu capital social, restituiu capital aos sócios por meio de redução do capital social ou partilha do acervo líquido, quando aplicável ${ }^{179}$.

Ainda em relação aos dividendos distribuídos com base em lucros auferidos pelas pessoas jurídicas tributadas pelo lucro real, o segundo período destacado pela legislação é o ano-calendário de 1993. Em relação a esses rendimentos, a legislação isenta-os da tributação na fonte pelo Imposto sobre a Renda no momento do seu pagamento, sejam os beneficiários pessoas físicas ou jurídicas ${ }^{180}$.

\footnotetext{
${ }^{175}$ Lei ${ }^{\circ} 8.849 / 94$, artigo $2^{\circ}$, parágrafo $1^{\circ}$, Lei ${ }^{\circ} 9.064 / 95$, artigo $2^{\circ}$, e Regulamento do Imposto sobre a Renda - Decreto ${ }^{\circ} 3.000 / 99$, artigo 656.

${ }^{176}$ Lei $^{\circ}$ 8.849/94, artigo $3^{\circ}$, Lei $n^{\circ} 9.064 / 95$, artigo $2^{\circ}$, e Regulamento do Imposto sobre a Renda - Decreto $\mathrm{n}^{\circ} 3.000 / 99$, artigo 658 .

${ }^{177}$ Nesse caso, o valor do capital restituído será considerado lucro ou dividendo distribuído, sujeito, nos termos da legislação pertinente, à tributação na fonte e na declaração de rendimentos, quando for o caso, como rendimento dos sócios da pessoa jurídica.

${ }^{178}$ Nesse caso, o montante dos lucros capitalizados será considerado, até o montante da redução do capital, atualizado monetariamente até 31 de dezembro de 1995, como lucro ou dividendo distribuído, sujeito, na forma da legislação pertinente, à tributação na fonte e na declaração de rendimentos, quando for o caso, como rendimento dos sócios da pessoa jurídica.

${ }^{179}$ Lei $n^{\circ} 8.849 / 94$, artigo $3^{\circ}$, parágrafos $3^{\circ}$ e $4^{\circ}$, Lei ${ }^{\circ} 9.064 / 95$, artigo $2^{\circ}$, Lei $n^{\circ} 9.249 / 95$, artigo $4^{\circ}$, e Regulamento do Imposto sobre a Renda - Decreto $\mathrm{n}^{\circ} 3.000 / 99$, artigo 658, parágrafos $2^{\circ}$ e $3^{\circ}$. Exceção a essas regras é feita aos casos (i) em que o aumento do capital social é realizado mediante incorporação de reserva de capital formada com ágio na emissão de ações, com o produto da alienação de partes beneficiárias ou bônus de subscrição, ou com correção monetária do capital; (ii) em que a redução de capital é realizada em virtude de devolução aos herdeiros da parte do sócio falecido, nas sociedades de pessoas; (iii) de rateio do acervo líquido da pessoa jurídica dissolvida, se o aumento de capital tiver sido realizado com incorporação de ações ou quotas bonificadas por sociedade de que era sócio ou acionista; (iv) de reembolso de ações, em virtude de exercício, pelo acionista, de direito de retirada (Lei $n^{\circ}$ 8.849/94, artigo $3^{\circ}$, parágrafo $5^{\circ}$, Lei $n^{\circ} 9.064 / 95$, artigo $2^{\circ}$, e Regulamento do Imposto sobre a Renda - Decreto $\mathrm{n}^{\circ}$ $3.000 / 99$, artigo 658 , parágrafo $4^{\circ}$ ).

${ }^{180}$ Lei n $^{\circ} 8.383 / 91$, artigo 75 e artigo 659 do regulamento do Imposto sobre Renda - Decreto no $3.000 / 99$.
} 
O terceiro e último período individualizado em relação às pessoas jurídicas tributadas com base no regime de lucro real tem início em $1^{\circ}$ de janeiro de 1989 e término em 31 de dezembro de 1992. Os dividendos distribuídos com base em lucros gerados nesse período também estão sujeitos à isenção do Imposto sobre a Renda na fonte ${ }^{181}$, mas, para tanto, a legislação estabelece que os lucros devem ter sido tributados à alíquota de $8 \%$ (oito por cento) no momento da sua apuração, conforme a legislação vigente à época ${ }^{182}$.

Essa isenção tributária é extensiva aos lucros capitalizados, desde que seja cumprida a mesma condição de tributação dos lucros no momento da sua apuração. Especialmente em relação aos sócios estrangeiros que decidirem pela capitalização, a legislação vigente exige o respeito ao lapso temporal de cinco anos, mencionado acima em relação à capitalização de lucros auferidos no período compreendido entre os anoscalendário de 1994 e $1995^{183}$.

Quanto aos dividendos pagos ou creditados a pessoas jurídicas, sócias de sociedade tributada com base no regime de lucro presumido, também existe previsão de isenção de retenção na fonte do Imposto sobre a Renda incidente sobre os dividendos distribuídos, porém ela é aplicável àqueles decorrentes de lucros apurados em período anterior a 31 de dezembro de 1994.

Na hipótese de o lucro distribuído ultrapassar o valor do lucro presumido, a diferença a maior, deduzida do valor do Imposto sobre a Renda, deverá ser tributada na pessoa do sócio ${ }^{184}$.

Exceção a essas regras são os dividendos distribuídos a sócios estrangeiros, pessoas físicas ou jurídicas, em relação a lucros auferidos até 31 de dezembro de 1995. Nesse caso, no momento da sua distribuição, esses rendimentos estão sujeitos às seguintes alíquotas: (i) $15 \%$ (quinze por cento), se referentes a lucros apurados nos anos-calendário de 1994 e 1995; (ii) 25\% (vinte e cinco por cento), se referentes a lucros apurados nos anos-calendário anteriores.

\footnotetext{
${ }^{181}$ Lei $\mathrm{n}^{\mathrm{o}} 7.713 / 88$, artigo 36, parágrafo único, e Regulamento do Imposto sobre a Renda - Decreto $\mathrm{n}^{\mathrm{o}}$ $3.000 / 99$, artigo 660 .

${ }^{182}$ Artigo 35 da Lei ${ }^{\circ} 7.713 / 88$.

${ }^{183}$ Lei no $7.799 / 89$, artigo 71, e Regulamento do Imposto sobre a Renda - Decreto no 3.000/99, artigo 700.

${ }^{184}$ Regulamento do Imposto sobre a Renda - Decreto n ${ }^{\circ} 3.000 / 99$, artigo 664.
} 


\section{A análise tributária das vantagens decorrentes do financiamento por meio de capital de terceiros e dos efeitos da caracterização da subcapitalização nominal}

Conforme analisado em detalhes no Capítulo I deste trabalho, a forma mais comumente adotada para a realização de operações de crédito, como é o caso do financiamento das sociedades por meio de capital de terceiros, é a utilização de contratos de empréstimo, principalmente empréstimos de bens fungíveis. Por bens fungíveis, entendam-se aqueles que podem ser substituídos por outros da mesma espécie, qualidade e quantidade $^{185}$, como é o caso do dinheiro. Na lição de Orlando Gomes, o dinheiro é bem fungível por excelência ${ }^{186}$.

O contrato de empréstimo pode ser de duas espécies diferentes: o comodato e o mútuo.

O comodato é, por definição, o empréstimo gratuito de coisas não fungíveis ${ }^{187}$. Ele não é, portanto, a espécie de contrato de empréstimo normalmente utilizada para o financiamento de sociedades, dado que o dinheiro não é bem infungível. Ainda, o financiamento de sociedades por meio de capital de terceiros é, regra geral, sujeito ao pagamento de remuneração e o comodato, diferentemente, é espécie de empréstimo gratuito.

A espécie de contrato de empréstimo que nos interessa é o mútuo, definido, nos termos do artigo 586 do Código Civil - Lei $\mathrm{n}^{\mathrm{o}}$ 10.406/02, simplesmente como o empréstimo de coisas fungíveis. Dentre as características do mútuo listadas no mesmo regramento, encontra-se uma, típica de financiamentos de sociedades por meio de capital de terceiros.

O artigo 587 determina que todos os riscos do bem objeto do contrato de mútuo devem ser assumidos pelo mutuário. Ora, nos contratos de empréstimo para financiamento de sociedades, são estas que possuem a obrigação de aplicar o valor emprestado corretamente, de forma a permitir que a sua atividade gere resultados positivos, que permitam a devolução do valor ao mutuante.

\footnotetext{
${ }^{185}$ Código Civil - Lei n ${ }^{\circ}$ 10.406/02, artigo 85.

${ }^{186}$ GOMES, Orlando. Introdução ao direito civil. 10. ed. Rio de Janeiro: Ed. Forense, 1988. p. 231. No mesmo sentido, MIRANDA, Francisco Cavalcanti Pontes de. op. cit., v. 2, p. 25.

${ }^{187}$ Código Civil - Lei n ${ }^{\circ} 10.406 / 02$, artigo 579.
} 
Decorrente do fator risco, intrínseco ao mútuo, está a idéia de remuneração do mutuante no caso de empréstimo de dinheiro. Se ao mutuário é imputado o risco pela devolução da quantia emprestada, é possível que seja devida remuneração ao mutuante pelo risco a que está sujeito pelo não-cumprimento da obrigação de devolução pelo mutuário. Ademais, durante o prazo do mútuo, o mutuante deixa de aplicar a quantia objeto do contrato em outras atividades ou investimentos, o que também justifica o recebimento de determinada remuneração. A essa conseqüência do mútuo, Pontes de Miranda dá o nome de investibilidade da quantia cedida ${ }^{188}$.

Remuneração eventualmente instituída para esses fins é conhecida como juros ${ }^{189}$. Segundo Carvalho Santos, desde que não sejam exorbitantes, os juros "são uma justa compensação ao mutuante pela álea que corre o capital emprestado e um prêmio para induzi-lo ao empréstimo" $" 190$. No mesmo sentido, Carvalho de Mendonça afirma que "os juros representam a prestação devida ao credor como compensação ou indenização pela temporária privação, ou pelo uso de uma quantidade de cousas fungíveis, chamada principal, e pelo risco do reembolso desta" ${ }^{\prime 191}$.

Em termos práticos, portanto, os juros podem ser definidos, no caso dos financiamentos por meio de mútuos, como o produto ou o fruto ${ }^{192}$ do capital aplicado, representando a remuneração pelo risco de reembolso e pelo tempo durante o qual a quantia cedida ficou indisponível para uso do mutuante.

Vale ressaltar que a estipulação dos juros não é compulsória nos termos do Direito Brasileiro Positivo, podendo existir mútuos com ou sem previsão de pagamento de juros. Especialmente em relação aos mútuos para fins econômicos, como é o caso dos contratos de empréstimos para financiamento de sociedades, presumem-se devidos os juros, os quais estão limitados à taxa que estiver em vigor para a mora do pagamento de impostos devidos à Fazenda Nacional, qual seja, a Taxa Selic ${ }^{193}$. A Taxa Selic é a taxa referencial do Sistema

\footnotetext{
${ }^{188}$ MIRANDA, Francisco Cavalcanti Pontes de. op. cit., v. 42, p. 29.

${ }^{189} \mathrm{O}$ mútuo firmado com previsão de pagamento de juros é conhecido como mútuo feneratício.

${ }^{190}$ SANTOS, J. M. de Carvalho. Código Civil brasileiro interpretativo. 8. ed. Rio de Janeiro: Ed. Freitas Bastos, 1964. v. 17, p. 452.

${ }^{191}$ MENDONÇA, J. X. Carvalho de. Tratado de direito comercial brasileiro. 4. ed. Rio de Janeiro: Ed. Freitas Bastos, 1947. v. 6, p. 283-284.

${ }^{192}$ SANTOS, J. M. de Carvalho. op. cit., p. 451. No mesmo sentido, MIRANDA, Francisco Cavalcanti Pontes de. op. cit., v. 42, p. 29. Esse mesmo doutrinador, ao se referir à origem dos juros, ensina que "são os interesses, as usuras do direito romano, donde, posteriormente, em sentido pejorativo, 'usura', 'usurário', 'usurar'”.

${ }^{193}$ Artigos 591 e 406 do Código Civil - Lei n 10.406/02.
} 
Especial de Liquidação e Custódia, fixada mensalmente pelo Conselho de Política Monetária do Banco Central - COPOM.

Apenas a título de curiosidade, a legislação vigente anteriormente à publicação do Código Civil de 2002 previa que a taxa de juros podia ser pactuada livremente entre as partes do contrato de mútuo ${ }^{194}$. Havia, entretanto, limitação imposta pela própria Constituição Federal ${ }^{195}$ e pela Lei de Usura - Decreto $n^{\mathbf{0}} 22.626 / 33^{196}$, segundo a qual as taxas de juros não poderiam ser superiores a $12 \%$ (doze por cento) ao ano.

\subsection{O tratamento tributário dispensado aos juros decorrentes de empréstimos a sociedades brasileiras}

Da mesma forma realizada em relação aos dividendos, mas com relativamente menos variáveis, a análise do tratamento tributário dos juros decorrentes de empréstimo será efetuada sob duas diferentes perspectivas: a do mutuante e a do mutuário.

Para fins tributários, os juros devidos ao mutuante são equiparados a rendimentos de aplicação financeira de renda fixa e, como tal, estão sujeitos à tributação na fonte no momento do seu pagamento ${ }^{197}$. As alíquotas atualmente aplicáveis são aquelas previstas no artigo $1^{\circ}$ da Lei $n^{\circ} 11.033 / 04^{198}$, que variam regressivamente em função do prazo do

\footnotetext{
${ }^{194}$ Artigo 1.262 do Código Civil de 1916 - Lei n ${ }^{\circ} 3.071 / 16$.

${ }^{195}$ Redação do artigo 192, parágrafo $3^{\circ}$, vigente até 30 de maio de 2003, quando foi publicada a Emenda Constitucional $n^{\circ} 40$, que alterou a redação desse artigo, revogando seu parágrafo $3^{\circ}$, sem trazer qualquer nova estipulação nesse sentido.

${ }^{196}$ Artigo $1^{\circ}$.

${ }^{197}$ Lei $\mathrm{n}^{\circ} 8.981 / 95$, artigo 65 , parágrafo $4^{\circ}$, alínea 'c', parágrafo $7^{\circ}$, alínea 'b', e parágrafo $8^{\circ}$, e Regulamento do Imposto sobre a Renda - Decreto $\mathrm{n}^{\circ}$ 3.000/99, artigos 730, inciso III, 732, inciso II, e 733, inciso I.

“Artigo 65. O rendimento produzido por aplicação financeira de renda fixa, auferido por qualquer beneficiário, inclusive pessoa jurídica isenta, a partir de $1^{\circ}$ de janeiro de 1995 , sujeita-se à incidência do Imposto de Renda na fonte à alíquota de dez por cento.

(...)

Parágrafo $4^{\circ}$. O disposto neste artigo aplica-se também:

(...)

c) aos rendimentos auferidos pela entrega de recursos a pessoa jurídica, sob qualquer forma e a qualquer título, independentemente de ser ou não a fonte pagadora instituição autorizada a funcionar pelo Banco Central do Brasil."

(...)

Parágrafo $7^{\circ}$. O imposto de que trata este artigo será retido:

(...)

b) por ocasião do pagamento dos rendimentos, ou da alienação do título ou da aplicação, nos demais casos.

Parágrafo $8^{\mathbf{0}}$. É responsável pela retenção do imposto a pessoa jurídica que receber os recursos, no caso de operações de transferência de dívidas, e a pessoa jurídica que efetuar o pagamento do rendimento, nos demais casos."

${ }^{198}$ Veja artigo $5^{\circ}$ da Lei ${ }^{\circ} 9.779 / 95$.
} 
empréstimo concedido, conforme segue: (a) 22,5\% (vinte e dois inteiros e cinco décimos por cento), para empréstimos com prazo de até 180 (cento e oitenta) dias; (b) 20\% (vinte por cento), para empréstimos com prazo de 181 (cento e oitenta e um) dias até 360 (trezentos e sessenta) dias; (c) 17,5\% (dezessete inteiros e cinco décimos por cento), para empréstimos com prazo de 361 (trezentos e sessenta e um) dias até 720 (setecentos e vinte) dias; (d) 15\% (quinze por cento), para empréstimos com prazo acima de 720 (setecentos e vinte) dias.

O imposto retido na fonte nesses termos será considerado definitivo, no caso de mutuantes pessoas físicas ou pessoas jurídicas tributadas com base no regime do lucro presumido $^{199}$.

Para mutuantes pessoas jurídicas tributadas com base no regime do lucro real, o valor do Imposto sobre a Renda retido na fonte deverá ser deduzido do imposto apurado no encerramento do período. Portanto, para esses mutuantes, o tratamento tributário aplicável é simples e claro: os juros recebidos são considerados receita financeira e, como tal, devem ser incluídos no lucro operacional.

$\mathrm{Na}$ hipótese de a operação de empréstimo ter vencimento posterior ao encerramento do período de apuração, os juros recebidos por pessoas jurídicas poderão ser rateados entre os períodos correspondentes ${ }^{200}$.

Quanto aos mutuantes pessoas físicas ou jurídicas, residentes ou domiciliadas no exterior, os juros pagos, creditados, entregues ou remetidos estarão sujeitos à retenção na fonte do Imposto sobre a Renda à alíquota de $15 \%$ (quinze por cento) ${ }^{201}$, ressalvados os casos de aplicação de tratamento tributário específico previsto em acordos para evitar a dupla tributação, conforme será oportunamente analisado.

A alíquota desse imposto será majorada para $25 \%$ (vinte e cinco por cento) quando a residência do mutuante for considerada país ou dependência que não tribute a renda ou que a tribute à alíquota inferior a $20 \%$ (vinte por cento) ${ }^{202}$. Vale relembrar que,

\footnotetext{
${ }^{199}$ Artigo 77 da Lei $n^{\circ} 8.981 / 95$.

${ }^{200}$ Decreto-Lei $n^{\circ} 1.598 / 77$, artigo 17 , Lei $n^{\circ} 8.981 / 95$, artigo 76 , parágrafo $2^{\circ}$, Lei $n^{\circ}$ 9.249/95, artigo 11 , parágrafo $3^{\circ}$, e Regulamento do Imposto sobre a Renda - Decreto $n^{\circ} 3.000 / 99$, artigo 373.

${ }^{201}$ Decreto-Lei $n^{\circ}$ 5.844/43, artigo 100, Lei $n^{\circ} 3.470 / 58$, artigo 77, Lei $n^{\circ}$ 9.249/95, artigo 28, e Regulamento do Imposto sobre a Renda - Decreto $\mathrm{n}^{\mathrm{o}} 3.000 / 99$, artigo 702. Na hipótese de o beneficiário dos juros ser residente ou domiciliado em país ou dependência que não tribute a renda ou que a tribute à alíquota inferior a vinte por cento, a alíquota desse imposto será de $25 \%$ (vinte e cinco por cento).

${ }^{202}$ Decreto-Lei no 5.844/43, artigo 100, Lei no 3.470/58, artigo 77, Lei n ${ }^{\circ}$ 9.249/95, artigo 23, Lei $n^{\circ}$ 9.779/99, artigos $7^{\circ}$ e $8^{\circ}$, e Regulamento do Imposto sobre a Renda - Decreto $n^{\circ} 3.000 / 99$, artigo 685, inciso II, alínea b.
} 
recentemente, com a publicação da Lei no 11.727/08, a alíquota majorada também se aplica às remessas de juros a beneficiário residente ou domiciliado em país ou dependência cuja legislação não permita o acesso a informações relativas à composição societária de pessoas jurídicas, à sua titularidade ou à identificação do beneficiário efetivo de rendimentos atribuídos a não-residentes.

Sob a perspectiva do mutuário, pessoa jurídica residente ou domiciliada no país $^{203}$, os juros pagos ou incorridos em relação a contratos de empréstimos são despesas financeiras, em princípio, dedutíveis para fins de cálculo do Imposto sobre a Renda. Entretanto, em alguns casos, o registro e a dedutibilidade dessa despesa devem observar regras específicas previstas na legislação em vigor ${ }^{204}$, quais sejam: (i) os juros pagos antecipadamente deverão ser apropriados, pro rata temporis, nos períodos de apuração correspondentes; (ii) os juros de empréstimos contraídos para financiar a aquisição ou construção de bens do ativo permanente, incorridos durante as fases de construção e préoperacional, podem ser registrados no ativo diferido para amortização apropriada.

Especialmente em relação aos juros devidos em virtude de empréstimos contraídos com sociedades controladas ou coligadas domiciliadas ou residentes no exterior, a dedutibilidade para fins de cálculo do Imposto sobre a Renda está condicionada à inexistência de lucros não disponibilizados para a controladora residente no Brasil ${ }^{205}$. Essa regra, apesar de não tratar de empréstimos concedidos por sócios, mas por sociedades controladas ou coligadas, pode ser vista como uma tentativa de desencorajar a prática de empréstimos excessivos entre partes vinculadas, conforme será visto em detalhes no item 3.2. deste Capítulo.

É importante notar que, em relação a empréstimos firmados com pessoa residente no exterior, considerada vinculada ao mutuário brasileiro ${ }^{206}$, em que o contrato não seja

\footnotetext{
${ }^{203} \mathrm{Em}$ virtude do objeto deste trabalho, será analisado apenas o tratamento tributário dos juros devidos por mutuários pessoas jurídicas residentes ou domiciliadas no Brasil. Em decorrência dessa limitação, também serão excluídos comentários específicos aplicáveis a operações transnacionais, nas quais o mutuante é pessoa residente ou domiciliada no País.

${ }^{204}$ Decreto-Lei $\mathrm{n}^{\circ} 1.598 / 77$, artigo 17 , parágrafo único, e Regulamento do Imposto sobre a Renda - Decreto $\mathrm{n}^{\mathrm{o}} 3.000 / 99$, artigo 374, incisos I e II.

${ }^{205}$ Lei $n^{\circ} 9.532 / 97$, artigo $1^{\circ}$, parágrafo $3^{\circ}$, e Regulamento do Imposto sobre a Renda - Decreto $n^{\circ} 3.000 / 99$, artigo 374, parágrafo único.

${ }^{206}$ Para esses fins, pessoa vinculada à pessoa jurídica localizada no País é entendida como: (i) a sua matriz, filial ou sucursal; (ii) pessoa física ou jurídica cuja participação societária no seu capital social a caracterize como sua controladora ou coligada nos termos da Lei das Sociedades Anônimas - Lei n ${ }^{\circ}$ 6.404/76; (iii) pessoa jurídica que seja caracterizada como sua controlada ou coligada, também nos termos da Lei das Sociedades Anônimas - Lei n $n^{\circ}$ 6.404/76; (iv) pessoa jurídica que está sob o mesmo controle societário ou administrativo comum ou cujo capital social é detido pela mesma pessoa física ou jurídica em montante
} 
registrado no Banco Central do Brasil, a dedutibilidade dos juros, para fins de determinação do lucro real, está limitada ao valor resultante da adição de 3\% (três por cento) à taxa Libor $^{207}$ prevista para depósitos em dólares dos Estados Unidos da América pelo prazo de seis meses ${ }^{208}$.

Por fim, ressalta-se que a devolução do valor principal do empréstimo não está sujeita a qualquer tributação no nível do mutuante, seja por meio do mecanismo de retenção na fonte ou não. Isso porque, conforme visto anteriormente neste Capítulo, a titularidade dos recursos emprestados não se altera e o mutuário tem a obrigação de devolução do mesmo valor ao mutuante. A transferência dos recursos entre as partes não representa, portanto, qualquer aumento no patrimônio do mutuário ou do mutuante e, conseqüentemente, não se justifica a tributação desse valor pelo Imposto sobre a Renda ${ }^{209}$. A sua devolução também não pode ser considerada uma despesa para o mutuário, uma vez que este está apenas devolvendo parcela do patrimônio do mutuante a qual estava em seu $\operatorname{poder}^{210}$.

\subsection{A caracterização da subcapitalização nominal e os impactos tributários para a sociedade mutuária e para os sócios mutuantes}

Conforme amplamente analisado no Capítulo I do presente trabalho, a decisão quanto à estrutura de capital de uma sociedade está pautada, dentre outros fatores, nos

igual ou maior a $10 \%$ (dez por cento); (v) pessoa física ou jurídica que, em conjunto com a pessoa jurídica domiciliada no Brasil, tiver participação societária no capital social de uma terceira pessoa jurídica, cuja soma as caracterize como controladoras ou coligadas; (vi) pessoa física ou jurídica que seja sua associada, na forma de consórcio ou condomínio; (vii) pessoa física que for parente ou afim até o terceiro grau, cônjuge ou companheiro de qualquer de seus diretores ou de seu sócio ou acionista controlador em participação direta ou indireta; (viii) pessoa física ou jurídica que goze de exclusividade, como seu agente, distribuidor ou concessionário, para a compra e venda de bens, serviços ou direitos; (ix) pessoa física ou jurídica, residente ou domiciliada no exterior, em relação à qual a pessoa jurídica domiciliada no Brasil goze de exclusividade, como agente, distribuidora ou concessionária, para a compra e venda de bens, serviços ou direitos.

${ }^{207}$ London Interbank Offered Rate ou taxa interbancária do mercado de Londres (tradução livre).

${ }^{208}$ Esse limite é anual e deve ser aplicado proporcionalmente em função do período a que se referirem os juros (Artigos 22 e 23 da Lei n ${ }^{\circ}$ 9.430/96 e Regulamento do Imposto sobre a Renda - Decreto $n^{\circ}$ 3.000/99, artigos 243 e 244).

${ }^{209}$ Nos termos do artigo 43 do Código Tributário Nacional - Lei $n^{\circ}$ 5.172/66, o Imposto sobre a Renda tem como fato gerador a aquisição da disponibilidade econômica ou jurídica: (i) de renda, assim entendido o produto do capital, do trabalho ou da combinação de ambos; (ii) de proventos de qualquer natureza, assim entendidos os acréscimos patrimoniais não compreendidos no item (i).

${ }^{210} \mathrm{Na}$ lição de Bulhões Pedreira, despesa "significa custo a que não corresponde acréscimo de valor ao ativo e, portanto, que causa diminuição do patrimônio líquido" (PEDREIRA, José Luiz Bulhões. op. cit., p. 466). 
impactos tributários decorrentes das formas de financiamento eleitas para a estruturação do capital aplicado.

No Sistema Tributário Brasileiro, o financiamento por meio de capital de terceiros, em princípio, apresenta clara vantagem para a sociedade na medida em que o pagamento de juros gerará despesa dedutível para fins de cálculo do Imposto sobre a Renda devido. Diferentemente, na distribuição de dividendos inerente ao financiamento por meio de capital próprio, além de não serem dedutíveis para fins fiscais, os recursos decorrem de lucro já tributado na sociedade à alíquota total de aproximadamente 34\%. Para esses fins, estamos assumindo que a sociedade é tributada pelo Imposto sobre a Renda à alíquota de $25 \%$ e pela Contribuição Social sobre o Lucro Líquido à alíquota de $9 \%$.

Em contrapartida, sob a perspectiva da fonte de financiamento, os dividendos possuem a vantagem da isenção tributária, sem qualquer previsão de tributação na fonte ou no nível dos sócios financiadores do capital aplicado. Os juros, diferentemente, estão sempre sujeitos à tributação pelo Imposto sobre a Renda, seja na fonte ou na própria figura dos investidores.

Apesar de serem normas específicas do Direito Brasileiro, regra geral, o tratamento tributário dispensado aos dividendos é mais gravoso do que aquele dispensado aos juros. Aliás, diferentemente do Brasil, muitos países não prevêem a isenção total de carga tributária sobre esses rendimentos no nível do sócio.

Diante dessa enorme disparidade entre as regras tributárias aplicáveis ao pagamento de juros e de dividendos, as sociedades se sentem incentivadas a optar pelo financiamento por meio de capital de terceiros, o que, consequientemente, pode ocasionar a caracterização da subcapitalização nominal com implicações drásticas tanto para as sociedades como para os seus sócios. Esse entendimento é confirmado por Abadan Jasmon e Junaid Shaikh, que afirmam que os sistemas tributários encorajam as sociedades a optar pelos empréstimos em detrimento dos investimentos diretos ${ }^{211}$.

\footnotetext{
${ }^{211}$ JASMON, Abadan; SHAIKH, Junaid M. op. cit., p. 39. No mesmo sentido, veja BURILOVICH, Linda. Planning techniques to avoid the reclassification of shareholder debt as equity. The Tax Adviser, New York, v. 37, n. 12, p. 708, 2006.
} 
É importante ressaltar, entretanto, que Ruud Mooij ressalva que, apesar dos efeitos tributários vantajosos, nem sempre a utilização de empréstimos para o financiamento da sociedade é a melhor opção ${ }^{212}$.

Sobre esse assunto, vale relembrar que, muitas vezes, a mera falta de equilíbrio entre o capital de terceiros e o capital próprio não é suficiente para questionar a estrutura de capital de determinada sociedade, desconsiderando os juros pagos para qualificá-los como dividendos.

Segundo Heleno Taveira Tôrres, é necessário que a relação entre débitos e capital próprio aponte para um endividamento excessivo da sociedade (hidden equity capitalization), segundo as regras pré-estabelecidas pelo ordenamento aplicável e, ainda, que esse endividamento excessivo seja superior àquele que poderia ser conseguido com terceiros em situações normais de mercado (arm's length $)^{213}$.

Richard M. Lipton e Steven R. Dixon ${ }^{214}$, ao tratarem do assunto, ensinam que, muitas vezes, as condições dos negócios implicam a dificuldade em eleger os sujeitos que realmente atuam como mutuantes e aqueles que figuram como sócios ${ }^{215}$.

Assim, também é importante analisar se os empréstimos realizados pelos sócios possuem características inerentes às participações societárias. Essa situação pode ser encontrada, por exemplo, em empréstimos com prazo de vencimento demasiadamente longo e fora dos padrões comumente adotados, contratos de empréstimos com possibilidade de conversão da dívida em investimento direto na sociedade, empréstimos com taxa de juros calculada em função dos resultados da sociedade etc.

Esse entendimento é confirmado por Linda Burilovich que, em artigo publicado na revista The Tax Adviser ${ }^{216}$, destaca a necessidade de substância econômica da operação de empréstimo por sócios, listando e comentando cada um dos fatores apontados pelo

${ }^{212}$ MOOIJ, Ruud A. De. Will corporate income taxation survive? De Economist, Leiden, v. 153, n. 3, p. 268, Sept. 2005.

${ }^{213}$ TÔRRES, Heleno Taveira. Direito tributário internacional: planejamento tributário e operações transnacionais, cit., p. 511. No mesmo sentido, seja JASMON, Abadan; SHAIKH, Junaid M. op. cit., p. 43; e BURILOVICH, Linda. op. cit., p. 710.

${ }^{214}$ LIPTON, Richard M.; DIXON, Steven R. When is a partner not a partner? When does a partnership exist? Journal of Taxation, New York, v. 100, n. 2, p. 73, Feb 2004.

${ }^{215}$ Ainda em relação à caracterização da subcapitalização nominal, vale ressaltar que a sua caracterização pode se dar mesmo quando há interposição de terceira pessoa na realização do empréstimo. Ou seja, os fundos são transferidos à sociedade pelos sócios, mas de forma indireta, transitando por terceiro, que, formalmente, figura como mutuante. Esse tipo de financiamento é denominado back-to-back. Sobre o assunto, veja TÔRRES, Heleno Taveira. Direito tributário internacional: planejamento tributário e operações transnacionais, cit., p. 522; e RIBEIRO, Antônio Carlos Silva. op. cit., p. 25.

${ }^{216}$ BURILOVICH, Linda. op. cit., p. 708-715. 
Internal Revenue Service ${ }^{217}$ dos Estados Unidos da América para a identificação de empréstimos que deveriam, na realidade, ser tratados como investimento direto na sociedade.

Dentre outros, a autora faz referência à necessidade de previsão de prazo de vencimento para a devolução do valor emprestado e de taxas de juros comumente adotadas em operações com terceiros em condições normais de mercado. Especialmente em relação à possibilidade de conversão da dívida em capital, a autora ressalta que a sua adoção no contrato de empréstimo é um dos indicadores utilizados para a desconsideração da operação passando a tratá-la como investimento direto.

Nesse mesmo sentido, Ted Englebrecht e Wei-Chih Chiang ${ }^{218}$ tratam, inclusive, da possibilidade de utilizar o risco do negócio como forma de identificação da natureza da operação. Conforme mencionado no Capítulo I deste trabalho, os sócios, diferentemente dos terceiros, assumem o risco do negócio e, com base nessa premissa, os referidos autores acreditam que, caso o empréstimo concedido não possua características semelhantes àquelas apontadas por Linda Burilovich, é inevitável a sua conversão em investimento direto.

No âmbito do Direito Tributário, a importância da subcapitalização nominal reside na repreensão à redução indevida da carga tributária aplicável à sociedade, por meio da realização excessiva de empréstimos por sócios. Essa prática ganha destaque nas operações que envolvem partes residentes em países diversos ${ }^{219}$. Isso porque, nesses casos, existe a possibilidade de utilização de regras vigentes em ordenamentos diferentes ${ }^{220} \mathrm{e}$ também de acordos para evitar a dupla tributação, que serão analisados em detalhes no Capítulo IV.

Regra geral, assim como no âmbito interno, o pagamento de juros a não-residente é mais vantajoso quando comparado à distribuição de dividendos. Isso porque, no pagamento de juros ao exterior não existem conseqüências similares à dupla tributação por

\footnotetext{
${ }^{217}$ Agência do Governo Norte-Americano que equivale à nossa Receita Federal do Brasil.

${ }^{218}$ ENGLEBRECHT, Ted D.; CHIANG, Wei-Chih. Use a business-risk perspective to distinguish debt from equity. Practical Tax Strategies, Boston, v. 79, n. 4, p. 224-231, Oct 2007.

${ }^{219}$ Sobre a prática da subcapitalização no âmbito internacional, veja MOOIJ, Ruud A. op. cit. p. 292.

${ }^{220}$ A prática de utilização de ordenamentos diversos para reduzir a carga tributária entre sociedades do mesmo grupo é conhecida como income shifting. Detalhes sobre o conceito e os métodos aplicáveis (dentre eles a realização de empréstimos em detrimento de investimentos diretos) podem ser encontrados em MOOIJ, Ruud A. op. cit. p. 291-294; GERKEN, Luder; MARKT, Jorg; SCHICK, Gerhard. Double income taxation as a response to tax competition in the EU. Intereconomics, Hamburg, v. 36, n. 5, p. 244-246, 252-253, Sept./Oct. 2001; JASMON, Abadan; SHAIKH, Junaid M. op. cit., p. 37-44, 60.
} 
distribuição societária internacional, já mencionada no item 1 deste Capítulo em relação à dupla tributação do lucro das sociedades.

Na distribuição de dividendos aos sócios, sejam eles residentes ou não-residentes, pressupõe-se a tributação prévia dos lucros no nível da sociedade. No momento da sua distribuição ao exterior, poderá haver, a cargo do beneficiário, a retenção na fonte do Imposto sobre a Renda e, ainda, a tributação por esse imposto no Estado de residência. No caso de dividendos pagos por sociedades brasileiras a sócios residentes no exterior, a isenção é efetiva apenas em relação à tributação na fonte, remanescendo, logicamente, a possibilidade de tributação dos rendimentos no país de residência do beneficiário.

Por sua vez, na distribuição de juros, apesar de sua remessa a não-residentes estar sujeita à tributação na fonte, regra geral, as alíquotas aplicáveis são inferiores àquelas praticadas em relação à tributação dos lucros no nível da sociedade e, ainda, seu valor é passível de dedução para fins de cálculo do imposto devido pela sociedade.

Ainda que a regulamentação quanto à subcapitalização nominal possa ser adotada pelos Estados para evitar ou mitigar esse tipo de prática, a sua aplicação se restringe ao território do Estado de residência da fonte pagadora. Conforme muito bem afirma Heleno Taveira Tôrres, ao Estado de residência do beneficiário dos rendimentos, não importa a sua desqualificação pelo Estado da fonte ${ }^{221}$.

No Direito Tributário Brasileiro, não existem regras específicas que coíbem a subcapitalização nominal. Existem apenas alguns dispositivos isolados que visam evitar o abuso de direito ou timidamente desencorajar a realização excessiva de empréstimos entre partes vinculadas $^{222}$.

O clássico exemplo de norma editada nesse sentido é o artigo 464, inciso VI, do

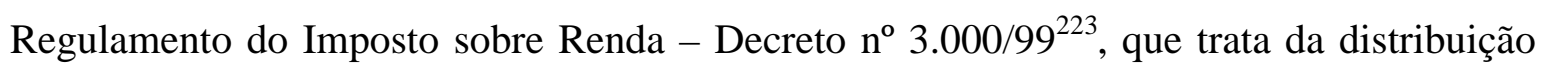
disfarçada de lucros. Segundo esse artigo, presume-se a distribuição de lucros nas operações em que a pessoa jurídica realiza negócio com pessoa ligada em condições mais vantajosas para esta última quando comparadas com as condições regularmente aplicáveis

\footnotetext{
${ }^{221}$ TÔRRES, Heleno Taveira. Direito tributário internacional: planejamento tributário e operações transnacionais, cit., p. 522.

${ }^{222}$ CEZAROTI, Guilherme. Subcapitalização de empresas. In: COSTA, Alcides Jorge, (Coord.). Direito tributário atual. São Paulo: Dialética, 2004. v. 18, p. 175.

${ }^{223}$ Decreto-Lei $\mathrm{n}^{\circ}$ 1.598/77, artigo 60, e Decreto-Lei n ${ }^{\circ} 2.065 / 83$, artigo 20, inciso II.
} 
no mercado ou passíveis de contratação com terceiros. A consequiência da concretização dessa hipótese é a indedutibilidade dos valores pagos ou creditados à pessoa ligada ${ }^{224}$.

A redação do artigo 464 é geral o suficiente para abranger as operações de mútuo entre a sociedade e seus sócios, quando firmadas em condições diversas daquelas que poderiam ser conseguidas com terceiros em situações normais de mercado (arm's length). No entanto, na lição de Heleno Taveira Tôrres, a norma prevista nesse artigo não pode ser aplicável à subcapitalização nominal na medida em que se contrapõe à política, atualmente vigente no Brasil, de incentivo ao financiamento de sociedades por meio de capital próprio $^{225}$. Como forma de expressão dessa política, o autor faz referência aos JSCP, que serão analisados em detalhe no próximo Capítulo.

Especialmente aplicáveis aos juros decorrentes de empréstimos entre partes relacionadas, os artigos 22 e 23 , da Lei $n^{\circ} 9.430 / 96^{226}$, também já citados no presente trabalho, limitam a dedutibilidade desses juros por meio de regras práticas e diretas. $\mathrm{O}$ parâmetro adotado por esses dispositivos para a indedutibilidade dos juros é o valor resultante da adição de 3\% (três por cento) à taxa Libor, prevista para depósitos em dólares dos Estados Unidos da América pelo prazo de seis meses. Ressalta-se que essa regra é aplicável apenas aos empréstimos firmados com pessoa vinculada, residente no exterior, por meio de contrato não registrado no Banco Central do Brasil.

Vale relembrar também a regra contida no já mencionado parágrafo $3^{\circ}$ do artigo $1^{\text {o }}$ da Lei n. ${ }^{\circ} 9.532 / 97^{227}$, com redação dada pela Medida Provisória n ${ }^{\mathrm{o}} 2158-35 / 01$, que também limita a dedutibilidade de juros de empréstimos, mas o faz com base em diferentes parâmetros. Segundo esse parágrafo, os juros decorrentes de empréstimos contraídos com sociedades controladas ou coligadas, domiciliadas ou residentes no exterior, são indedutíveis para fins de cálculo do Imposto sobre a Renda nas hipóteses em que existirem lucros não disponibilizados por essas sociedades ${ }^{228}$. Ou seja, o Direito Positivo Brasileiro desencoraja, por meio da indedutibilidade dos juros, a contratação de empréstimos com sociedades que devem, à sociedade brasileira, rendimentos decorrentes da participação societária.

\footnotetext{
${ }^{224}$ Decreto-Lei $\mathrm{n}^{\mathrm{o}}$ 1.598/77, artigo 62, Decreto-Lei $\mathrm{n}^{\mathrm{o}}$ 2.065/83, artigo 20, incisos VII e VIII, e Regulamento do Imposto sobre a Renda - Decreto $\mathrm{n}^{\circ} 3.000 / 99$, artigo 467, inciso V.

${ }^{225}$ TÔRRES, Heleno Taveira. Direito tributário internacional: planejamento tributário e operações transnacionais, cit., p. 538-539.

${ }^{226}$ Regulamento do Imposto sobre a Renda - Decreto no 3.000/99, artigos 243 e 244.

${ }^{227}$ Regulamento do Imposto sobre a Renda - Decreto n ${ }^{\circ} 3.000 / 99$, artigo 374, parágrafo único.

${ }^{228}$ Lei $\mathrm{n}^{\circ}$ 9.532/97, artigo $1^{\circ}$, parágrafo $3^{\circ}$, e Regulamento do Imposto sobre a Renda - Decreto $\mathrm{n}^{\circ} 3.000 / 99$, artigo 374, parágrafo único.
} 
Por fim, não se pode esquecer a regra contida no parágrafo único do artigo 116 do Código Tributário Nacional - Lei $\mathrm{n}^{\circ}$ 5.172/66, desconsiderando, para tanto, a discussão existente acerta da sua aplicabilidade ${ }^{229}$. Segundo esse dispositivo, a autoridade administrativa poderá desconsiderar atos ou negócios jurídicos praticados com a finalidade de dissimular a ocorrência do fato gerador do tributo ou a natureza dos elementos constitutivos da obrigação tributária.

A despeito de o Brasil não regulamentar a subcapitalização nominal, esta é uma prática observada por muitos ordenamentos estrangeiros, e.g., Estado Unidos da América, Espanha e França. Nem sempre essa regulamentação se dá por meio de normas específicas, diretamente dirigidas à subcapitalização nominal. É possível que ela se dê por meio da criação de cláusulas gerais antielisivas. Independentemente do tipo de norma adotada, Heleno Taveira Tôrres entende que a sua aplicação é condicionada à existência do conceito de subcapitalização no Direito Privado, motivo pelo qual o mencionado artigo 116 do Código Tributário Nacional - Lei $n^{\circ}$ 5.172/66 - não serve à regulamentação dessa prática no país ${ }^{230}$.

As normas especiais sobre a subcapitalização nominal oferecem, regra geral, maior segurança jurídica ao contribuinte, na medida em que esse estado pode ser direta e imediatamente identificado. Esse é o caso, por exemplo, da França, dos Estados Unidos da América, da Alemanha e do Japão, que adotam coeficientes de endividamento para definir o estado de subcapitalização, os quais podem ser aplicados aos sócios, considerados de forma individual ou coletiva. Adicionalmente a esse coeficiente, alguns países, por exemplo, a Austrália, adotam a estipulação de prazo limite para a manutenção do endividamento excessivo.

Diferentemente, as normas gerais antielisivas baseiam-se em critérios de igualdade (arm's length) em relação às operações com terceiros, de forma que sua aplicação pelo Estado é dotada de significativa subjetividade.

\footnotetext{
${ }^{229}$ Heleno Taveira Tôrres analisa esse assunto em detalhes em Direito tributário e direito privado: autonomia privada, simulação, elusão tributária. São Paulo: Ed. Revista dos Tribunais, 2003. p. 259-276.

${ }^{230}$ TÔRRES, Heleno Taveira. Direito tributário internacional: planejamento tributário e operações transnacionais, cit., p. 527.
} 


\section{CAPÍTULO III. A NATUREZA DOS JUROS SOBRE O CAPITAL PRÓPRIO E A SUA UTILIZAÇÃO COMO MECANISMO DE ELIMINAÇÃO DO TRATAMENTO TRIBUTÁRIO DISCRIMINATÓRIO DISPENSADO AO CAPITAL PRÓPRIO}

\section{Introdução à figura dos juros sobre o capital próprio}

Como forma de incentivo ao financiamento de empresas por meio de capital próprio, em 1995, foi publicada a Lei $n^{\circ}$ 9.249, que introduziu, no sistema legal brasileiro, a figura dos JSCP, entendidos como uma alternativa de remuneração aos sócios de sociedades residentes ou domiciliadas no país.

Diferentemente do previsto para o pagamento de dividendos, a mencionada legislação prevê que os valores creditados ou pagos a título de JSCP podem ser deduzidos do lucro real das pessoas jurídicas para efeito de apuração do Imposto sobre a Renda e da Contribuição Social sobre o Lucro Líquido ${ }^{231}$. Para tanto, é imprescindível que o seu cálculo seja realizado de acordo com as condições previstas em lei ${ }^{232}$, que serão analisadas em detalhe ainda neste Capítulo.

\footnotetext{
${ }^{231}$ Pedro Anan destaca os benefícios do pagamento de JSCP, comparando-os com os dividendos, por meio de exemplo numérico (ANAN JÚNIOR, Pedro. Remuneração dos sócios e acionistas e o planejamento fiscal. In: 322).

${ }^{232} \mathrm{O}$ artigo $9^{\circ}$ da Lei $\mathrm{n}^{\circ} 9.249 / 95$ assim estabelece:

“Artigo 9". A pessoa jurídica poderá deduzir, para efeitos de apuração do lucro real, os juros pagos ou creditados individualizadamente a titular, sócios ou acionistas, a título de remuneração sobre o capital próprio, calculados sobre as contas do patrimônio líquido e limitados à variação, pro rata dia, da Taxa de Juros a Longo Prazo - TJLP.

Parágrafo $1^{o}$. O efetivo pagamento ou crédito dos juros fica condicionado à existência de lucros, computados antes da dedução dos juros, ou de lucros acumulados e reservas de lucros, em montante igual ou superior ao valor de duas vezes os juros pagos ou creditados.

Parágrafo $2^{\text {}}$. Os juros ficarão sujeitos à incidência do imposto de renda na fonte à alíquota de quinze por cento, na data do pagamento ou crédito ao beneficiário.

Parágrafo $3^{\circ}$. O imposto retido na fonte será considerado:

I. antecipação do devido na declaração de rendimentos, no caso de beneficiário pessoa jurídica tributada com base no lucro real;

II. tributação definitiva, no caso de beneficiário pessoa física ou pessoa jurídica não tributada com base no lucro real, inclusive isenta, ressalvado o disposto no parágrafo $4^{o}$;

Parágrafo $4^{\circ}$. (Revogado)

Parágrafo 5o. (Revogado)
} 
A despeito de a lei de 1995 ter criado a figura do denominado JSCP, aplicável indistintamente a todas as sociedades residentes ou domiciliadas no país, a rigor, essa lei não foi uma inovação do sistema positivo brasileiro.

A Lei do Anonimato de 1940 - Decreto-Lei no 2.627/40 já previa, em seu artigo 129, parágrafo único, alíneas 'd' e 'e', a possibilidade de pagamento de juros aos sócios durante o período de instalação da sociedade, i.e., na sua fase pré-operacional. Nos termos desse artigo 129, a taxa dos juros podia ser fixada pelo estatuto da sociedade, limitada a $6 \%$ (seis por cento) ao ano ${ }^{233}$.

Segundo Trajano de Miranda Valverde ${ }^{234}$, o artigo 129 da Lei do Anonimato de 1940 visava atrair "pequenos capitais para as empresas, (...) que precisam de certo tempo para a produção de lucro. (...) a necessidade de um rendimento constante e regular é o motivo que afasta a grande massa dos pequenos detentores de capitais da colaboração nas empresas (...)"

A legislação vigente à época previa o correspondente tratamento tributário. $\mathrm{O}$ Regulamento do Imposto sobre a Renda de 1980 - Decreto no 85.450/80, artigo 209 ${ }^{235}$,

Parágrafo $6^{\circ}$. No caso de beneficiário pessoa jurídica tributada com base no lucro real, o imposto de que trata o $\$ 2^{\circ}$ poderá ainda ser compensado com o retido por ocasião do pagamento ou crédito de juros, a título de remuneração do capital próprio, a seu titular, sócios ou acionistas.

Parágrafo $7^{\boldsymbol{o}}$. O valor dos juros pagos ou creditados pela pessoa jurídica, a título de remuneração do capital próprio, poderá ser imputado ao valor dos dividendos de que trata o art. 202 da Lei no 6.404, de 15 de dezembro de 1976, sem prejuízo do disposto no $\$ 2^{\circ}$.

Parágrafo $8^{\circ}$. Para os fins de cálculo da remuneração prevista neste artigo, não será considerado o valor de reserva de reavaliação de bens ou direitos da pessoa jurídica, exceto se esta for adicionada na determinação da base de cálculo do imposto de renda e da contribuição social sobre o lucro líquido.

Parágrafo 9. (Revogado)

Parágrafo 10. (Revogado)"

233 “Artigo 129. No fim de cada ano ou exercício social, proceder-se-á a balanço geral, para a verificação dos lucros ou prejuízos.

Parágrafo único. Feito o inventário do ativo e passivo, a estimação do ativo obedecerá às seguintes regras:

(...)

d) entre os valores do ativo poderão figurar as despesas de instalação da sociedade, desde que não excedam de $10 \%$ (dez por cento) do capital social e sejam amortizadas anualmente;

e) nas despesas de instalação deverão ser incluídos os juros pagos aos acionistas durante o período que anteceder o início das operações sociais. Os estatutos fixarão a taxa de juro, que não poderá exceder de 6 $\%$ (seis por cento) ao ano, e o prazo para a amortização. (...)"

${ }^{234}$ VALVERDE, Trajano de Miranda. Sociedade por ações: comentários ao Decreto-Lei 2.627, de 26 de setembro de 1940. Rio de Janeiro: Forense, 1941. v. 2, p. 82.

235“'Artigo 209. Poderão ser amortizados:

(...)

II. os custos, encargos ou despesas, registrados no ativo diferido, que contribuirão para a formação do resultado de mais de um exercício social, tais como:

(...)

g) os juros pagos ou creditados aos acionistas durante o período em que anteceder o início das operações sociais, ou de implantação do empreendimento inicial; (...)" 
previa a amortização desses juros, com base no Decreto-Lei $\mathrm{n}^{\circ}$ 1.598/77, artigo 15, parágrafo 10 , alínea ' $b$ '236.

Com a reforma da Lei do Anonimato e a publicação da atual Lei das Sociedades Anônimas - Lei n ${ }^{\circ}$ 6.404/76, o artigo 129 não foi mantido. Entretanto, a redação do artigo 179, inciso V, da lei de 1976, vigente anteriormente à publicação da Lei no 11.638/07 e da Medida Provisória 449/08, previa que, dentre outras despesas, os juros pagos ou creditados aos sócios durante o período pré-operacional deveriam ser registrados no ativo diferido.

Ou seja, ainda que não existisse qualquer dispositivo na lei de 1976 sobre os limites para o pagamento de juros a sócios, foi mantida previsão quanto à sua forma de contabilização, o que nos permite concluir que a revogação dessa norma se deu apenas recentemente, com a publicação da Lei nº 11.638/07.

Foi mantida também a regulamentação tributária sobre o assunto. A regra contida no artigo 209 do regulamento de 1980 foi integralmente mantida no Regulamento do Imposto sobre a Renda de 1994 - Decreto $n^{\circ} 1.041 / 94^{237}$ e no Regulamento do Imposto

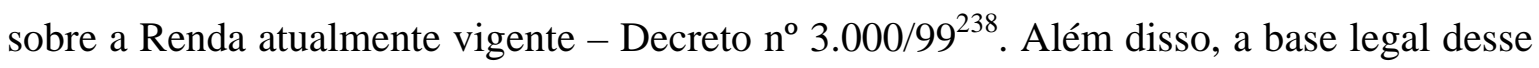
artigo 209, i.e., o artigo 15 do Decreto- Lei no 1.598/77, continua vigente e, ao menos até a publicação da Lei no 11.638/07, aplicável.

De forma semelhante, mas especificamente em relação às concessionárias de serviços públicos de energia elétrica, o Decreto n ${ }^{\circ} 41.019 / 57$, artigo 159, parágrafo $2^{\text {o239}}$, prevê que serão devidos juros em relação ao valor do capital próprio empregado em obras em andamento. Não existe, entretanto, qualquer previsão expressa de pagamento desses juros, mas de sua capitalização e conseqüente acréscimo ao custo da obra.

Também a Lei das Cooperativas de 1971 - Lei ${ }^{\circ}$ 5.764/71, em seu artigo 24, parágrafo $3^{\circ}$, prevê a possibilidade de pagamento de juros em favor dos associados das

\footnotetext{
${ }^{236}$ É importante notar que, além desses juros pagos aos sócios, apenas os juros pagos no âmbito das cooperativas estavam a salvo da indedutibilidade prevista no artigo 49 da Lei $n^{\circ} 4.506 / 64$.

${ }^{237}$ Artigos 266 e 287 do Regulamento do Imposto sobre a Renda de 1994 - Decreto no 1.041/94.

${ }^{238}$ Artigos 325 e 348 do Regulamento do Imposto sobre a Renda atualmente vigente - Decreto no 3.000/99.

239“"Artigo 159. Os bens e instalações em operação, em função do serviço concedido, devem ser demonstrados e apurados separadamente daqueles cujas obras estão em andamento e dos destinados a uso futuro, todos determinados na base do seu custo histórico.

(...)

Parágrafo $2^{\circ}$. A parte do investimento de obras em andamento, realizada com capital próprio, vencerá juros iguais à taxa de remuneração fixada para o investimento remunerável, até a data da entrada em serviços das instalações, juros êsse que serão capitalizados e acrescidos ao custo da obra."
} 
cooperativas, anualmente limitados a $12 \%$ (doze por cento) do capital social integralizado $^{240}$.

\section{Os juros sobre o capital próprio como custo de oportunidade e como mecanismo de equiparação de tratamento fiscal entre as remunerações dos capitais próprio e de terceiros}

A Exposição de Motivos do Projeto de Lei ${ }^{\circ}$ 913/95, posteriormente convertido na Lei n ${ }^{\circ}$ 9.249/95 (Exposição de Motivos do Ministro da Fazenda nº 325/95), afirma que a instituição dos JSCP foi um dos mecanismos adotados para a equiparação do tratamento fiscal dispensado aos diversos tipos de rendimentos do capital. Ou seja, a criação e a imputação de dedutibilidade fiscal aos JSCP visavam à equiparação entre o capital próprio e o capital de terceiros, no que se refere à tributação aplicável à sua remuneração.

O objetivo expresso da eliminação da discriminação de tratamento fiscal entre os capitais próprio e de terceiros é o desenvolvimento da capacidade produtiva das sociedades brasileiras, por meio do aumento do nível de investimentos sem o correspondente aumento do nível de endividamento da sociedade.

Os JSCP são, portanto, uma forma de o Governo Brasileiro mitigar a prática da subcapitalização nominal. Conforme visto no Capítulo anterior, uma das principais razões para essa prática é o tratamento tributário benéfico concedido aos juros em detrimento dos dividendos. A partir do momento em que é possível remunerar o capital próprio investido na sociedade por meio de rendimento sujeito a tratamento tributário equiparado àquele dos juros de empréstimo, não há mais que se falar dessa justificativa para a prática da subcapitalização nominal.

Esse entendimento é compartilhado com Heleno Taveira Tôrres que afirma que, apesar de o Brasil não possuir uma regulamentação sobre subcapitalização nominal, os

\footnotetext{
240 “Artigo 24. O capital social será subdividido em quotas-partes, cujo valor unitário não poderá ser superior ao maior salário mínimo vigente no País.

(...)

Parágrafo $3^{\circ}$. É vedado às cooperativas distribuírem qualquer espécie de benefício às quotas-partes do capital ou estabelecer outras vantagens ou privilégios, financeiros ou não, em favor de quaisquer associados ou terceiros excetuando-se os juros até o máximo de $12 \%$ (doze por cento) ao ano que incidirão sobre a parte integralizada."
} 
JSCP servem como um incentivo ao financiamento de empresas por meio de capital próprio $^{241}$.

A racionalidade da criação e da estrutura de cálculo dos JSCP pode ser analisada sob prisma econômico, com base na idéia de custo de oportunidade de investimento.

Ilse Maria Beuren, ao citar E. E. Burch e W. R. Henry, afirma que, inicialmente, o conceito de custo de oportunidade foi aplicado em relação aos fatores de produção e definido como "a renda líquida gerada pelo fator em seu melhor uso alternativo" 242.

Para esse conceito, portanto, presume-se (i) a existência de duas ou mais alternativas de utilização de determinado fator de produção ${ }^{243}$; (ii) que a opção por uma delas implica o abandono ou sacrifício das demais. Em decorrência desses elementos básicos, Ilse Maria Beuren define o custo de oportunidade, em termos gerais, como o resultado que seria proporcionado se a melhor alternativa tivesse sido eleita. Essa definição é compartilhada por autores renomados, por exemplo, Richard Bilas, Roger Miller, Richard Leftwich, Albert Meyers, Milton Spencer e Louis Siegelman ${ }^{244}$.

Aplicando esse conceito ao fator capital, pode-se afirmar que, em termos gerais, o seu custo de oportunidade corresponde aos juros de determinado investimento que oferece risco mínimo ou zero. Por essa razão, o Ministro da Fazenda da Bélgica, ao justificar a criação do benefício de dedução de juros calculados sobre o capital próprio naquele país, argumenta que essa dedução é baseada na teoria econômica, que demonstrou há muito tempo que, no custo do capital de risco, é possível isolar facilmente um componente correspondente a uma taxa de juros sem risco $^{245}$.

A mesma lógica pode ser aplicada aos JSCP criados pela Lei $\mathrm{n}^{\text {o }}$ 9.249/95. Conforme caput do artigo $9^{\circ}$ da Lei $n^{\circ} 9.249 / 95$, esses juros são calculados sobre as contas

\footnotetext{
${ }^{241}$ TÔRRES, Heleno Taveira. Direito tributário internacional: planejamento tributário e operações transnacionais, cit., p. 553.

${ }^{242}$ BEUREN, Ilse Maria. Conceituação e contabilização do custo de oportunidade. p. 1. Disponível em: <http://www.eac.fea.usp.br/cadernos/completos/cad08/conceituacao.pdf>. Acesso em: 23 maio 2008.

${ }^{243}$ No mesmo sentido, SANTOS, Ariovaldo. op. cit., p. 36, jun. 2007.

${ }^{244}$ BEUREN, Ilse Maria. op. cit., p. 2.

${ }^{245}$ Tradução livre do seguinte extrato de texto: "cette déduction s'appuie sur la théorie financière qui a démontré depuis longtemps que, dans le coût du capital à risque, on peut facilement isoler une composante correspondant à un taux d'intérêt sans risque." Exposição de motivos do Ministro da Fazenda da Bélgica em relação ao projeto de lei que originou a criação da "déduction pour capital à risque". KPMG. Disponível em: <http://www.kpmg.be/dbfetch/52616e646f6d495672f20d392141c5eee75cf6f3f9a9e56b3ab83a07decd1b96/ nid_memorie_van_toelichting-expos_des_motifs.pdf>. Acesso em: 13 out. 2008.
} 
do patrimônio líquido, com base na Taxa de Juros de Longo Prazo - TJLP ${ }^{246}$, que é divulgada periodicamente pelo Banco Central do Brasil e definida a partir da rentabilidade nominal média dos títulos da dívida pública externa e interna de aquisição voluntária.

A Taxa de Juros de Longo Prazo - TJLP - é calculada, portanto, com base em investimentos considerados de baixo risco, uma vez que os títulos da dívida pública são emitidos pelo próprio Estado. Além disso, é utilizada para cálculo da remuneração das Notas do Tesouro Nacional Série U, que também são títulos emitidos pelo Estado, cujo investimento é considerado de renda fixa com baixo risco de perda.

Assumindo que o patrimônio líquido representa o capital investido na sociedade, o resultado da aplicação da Taxa de Juros de Longo Prazo - TJLP - sobre as contas do patrimônio líquido, i.e., os JSCP, nada mais é do que o custo de oportunidade do capital próprio investido na sociedade.

Esse entendimento é confirmado por João Dácio Rolim, segundo o qual “assim como o capital de terceiros é remunerado por juros de mercado, do ponto de vista econômico, o capital próprio (dos sócios ou acionistas) igualmente apresenta um custo de oportunidade, $^{, 247}$.

Assim, ao instituir a possibilidade de pagamento de JSCP, com base no mesmo tratamento tributário aplicável às remunerações atreladas ao capital de terceiros, o Governo Brasileiro assegurou a equiparação de tratamento entre as fontes de financiamento, ao menos em relação ao custo de oportunidade do capital próprio.

Quanto à recorrente argumentação sobre a instituição dos JSCP decorrer da revogação da correção monetária do balanço ${ }^{248}$, acreditamos tratar-se, na realidade, de análise parcial da situação. Não se pode negar que a extinção da correção monetária do balanço representou um acréscimo à carga tributária das sociedades brasileiras, que, segundo Eliseu Martins, passaram a ser tributadas com base em lucro fictício ${ }^{249}$. Mas,

\footnotetext{
${ }^{246}$ A Taxa de Juros de Longo Prazo - TJLP foi instituída pela Medida Provisória n ${ }^{\circ}$ 684/94, posteriormente convertida na Lei $\mathrm{n}^{\circ}$ 9.365/96.

${ }^{247}$ ROLIM, João Dácio. A remuneração do capital próprio das pessoas jurídicas e a revogação da correção monetária de balanço pela Lei no 9.249/95. Repertório IOB de jurisprudência, São Paulo, n. 16, 2. P. 392, quinz. ago., 1996.

${ }^{248}$ Para maiores detalhes sobre o modelo brasileiro de correção monetária do balanço, veja MARTINS, Eliseu. Origem do modelo brasileiro de correção monetária das demonstrações financeiras. Boletim IOB: temática contábil e balanços, São Paulo, ano 38, n. 45, p. 1-7, nov. 2004.

${ }^{249}$ MARTINS, Eliseu. Um pouco de história dos juros sobre o capital próprio. Boletim IOB: temática contábil e balanços, São Paulo, ano 38, n. 49, p. 4, dez. 2004. Nesse mesmo artigo, esse autor explica, sob a ótica contábil, qual o papel dos JSCP na revogação da correção monetária das demonstrações financeiras e
} 
como afirma a própria Exposição de Motivos do Projeto de Lei n 913/95, o Governo Brasileiro pretendia simplificar a apuração da base de cálculo do Imposto sobre a Renda e reduzir a possibilidade de planejamentos fiscais. Objetivo legítimo, portanto.

Dessa forma, se a sua extinção representou um desincentivo ao financiamento de sociedades por meio de capital próprio, a criação dos JSCP, com a redução das alíquotas do Imposto sobre a Renda e a isenção dos dividendos, serviu à preservação da política econômica do Estado àquela época, qual seja, o incentivo ao investimento por meio de capital próprio $^{250}$.

\section{O tratamento tributário e contábil dispensado aos juros sobre o capital próprio.}

\section{Vantagem do seu pagamento ou crédito: previsão legal de dedutibilidade}

Seguindo a regra da compatibilidade de tratamento tributário entre as remunerações do capital próprio e de terceiros, segundo parágrafo $2^{\circ}$ do artigo $9^{\circ}$ da Lei $n^{\circ}$ 9.249/95 251 , os JSCP pagos ou creditados aos seus beneficiários, pessoas físicas ou jurídicas, residentes ou não no país, estão sujeitos à retenção do Imposto sobre a Renda na fonte à alíquota de $15 \%$ (quinze por cento) ${ }^{252}$.

O tratamento desse imposto retido na fonte no nível do sócio varia em função da sua qualidade de pessoa física ou jurídica. Sendo o sócio pessoa física, a tributação na fonte pelo Imposto sobre a Renda é considerada definitiva ${ }^{253}$. Quanto aos sócios pessoas jurídicas, independentemente do regime de tributação adotado, o valor do imposto retido na fonte à alíquota de $15 \%$ (quinze por cento) é considerado antecipação e pode ser compensado com o valor desse mesmo imposto devido no nível dos sócios ${ }^{254}$.

Em relação aos sócios pessoas jurídicas tributadas com base no regime de lucro real, o valor do Imposto sobre a Renda retido na fonte poderá, ainda, ser compensado com

conclui que esses juros realmente serviram para compensar os efeitos dessa revogação. Em sentido contrário à conclusão de Eliseu Martins, veja ROLIM, João Dácio. op. cit., p. 390-394.

${ }^{250}$ Nesse mesmo sentido, veja TÔRRES, Heleno Taveira. Juros sobre capital próprio - autonomia privada nos investimentos societários e suas implicações em matéria tributária, cit., v. 4, p. 370.

${ }^{251}$ Tributação na fonte incluída no artigo 668 do Regulamento do Imposto sobre a Renda - Decreto 3.000/99.

${ }^{252}$ Vale relembrar que as alíquotas regressivas aplicáveis na fonte aos juros decorrentes de contratos de mútuo decorrem de alteração introduzida na legislação em 2003, portanto, sete anos depois da criação dos JSCP.

${ }^{253}$ Artigo $9^{\circ}$, parágrafo $3^{\circ}$, inciso II, da Lei $\mathrm{n}^{\circ} 9.249 / 95$, e artigo 668 , parágrafo $1^{\circ}$, inciso II, do Regulamento do Imposto sobre a Renda - Decreto 3.000/99.

${ }^{254}$ Artigo $9^{\circ}$, parágrafo $3^{\circ}$, inciso I, da Lei $n^{\circ} 9.249 / 95$, Artigo 51 da Lei $n^{\circ} 9.430 / 96$ e artigo 668, parágrafo $1^{\circ}$, inciso I, do Regulamento do Imposto sobre a Renda - Decreto 3.000/99. 
o imposto retido por ocasião do pagamento ou crédito de JSCP aos sócios da sociedade beneficiária $^{255}$. Essa regra, a nosso ver, deixa clara a idéia de que os reais beneficiários dos rendimentos auferidos por meio da sociedade são os sócios. Isso porque o valor do Imposto sobre a Renda retido na fonte no momento do pagamento dos JSCP é, na realidade, devido pelos sócios da sociedade pagadora. Assim, ao possibilitar essa compensação, a legislação permite que os JSCP sejam considerados rendimentos do sócio indireto da sociedade pagadora.

Em um caso hipotético, essa situação poderia ser exemplificada da seguinte forma: uma determinada sociedade "A" é detida pela sociedade "B", que, por sua vez, é detida pela sociedade "C". A sociedade "A" delibera, aprova e distribui JSCP a seus sócios, dentre eles a sociedade "B", retendo na fonte o valor do Imposto sobre a Renda correspondente à alíquota de $15 \%$ (quinze por cento). Segundo a regra de compensação mencionada, o valor do imposto retido na fonte poderá ser utilizado para compensar a nova retenção do Imposto sobre a Renda, também calculado à alíquota de 15\% (quinze por cento), no momento do pagamento dos JSCP pela sociedade "B" à sociedade "C".

Assim, ao invés de compensar o imposto retido na fonte com o Imposto sobre a Renda devido pela própria sociedade "B" (o que seria natural, uma vez que o imposto retido no momento da distribuição dos juros por "A" a "B" é imputado a esta última sociedade), a legislação expressamente autoriza a sua compensação com o Imposto sobre a Renda a cargo da sociedade "C", sócia indireta de "A",256.

Em princípio, ao beneficiário dos JSCP é dada, ainda, a possibilidade de capitalização dos recursos, assegurada a manutenção da sua dedutibilidade no nível da sociedade. Apesar de não ser uma regra prevista em lei ordinária, a Instrução Normativa da Secretaria da Receita Federal n ${ }^{\circ}$ 41/98 expressamente estabelece que, uma vez creditado o valor referente aos JSCP em conta do passivo exigível da sociedade, o valor creditado, líquido do Imposto sobre a Renda incidente na fonte, poderá ser utilizado para integralização de aumento de capital, sem prejudicar o direito da sociedade à dedutibilidade desses valores. Nesse caso, portanto, o valor passível de capitalização, segundo a referida instrução normativa, corresponde a $85 \%$ (oitenta e cinco por cento) do valor bruto dos JSCP devidos aos sócios.

\footnotetext{
${ }^{255}$ Artigo $9^{\circ}$, parágrafo $6^{\circ}$, da Lei $n^{\circ} 9.249 / 95$, e artigo 668, parágrafo $2^{\circ}$, do Regulamento do Imposto sobre a Renda - Decreto 3.000/99.

${ }^{256}$ Assumindo, é claro, que "A" e "B" são sociedades tributadas pelo Imposto sobre a Renda com base no regime do lucro real.
} 
A esse respeito, vale ressaltar que a redação original do artigo $9^{\circ}$ da Lei $n^{\circ}$ 9.249/95 previa a possibilidade de capitalização dos JSCP, mantendo o benefício da sua dedutibilidade fiscal ${ }^{257}$. Em 1996, com a publicação da Lei no 9.430/96, essa previsão legal foi expressamente revogada. Entretanto, após a sua revogação, a Instrução Normativa da Secretaria da Receita Federal n ${ }^{\circ}$ 41/98 foi editada, contendo em seu texto a referida regra, o que ocasionou a prática recorrente da capitalização desses juros pelos contribuintes.

Sob a perspectiva da sociedade, fonte pagadora dos JSCP, desde que observados os requisitos legais para o seu cálculo, o valor dos juros é considerado despesa dedutível para fins de apuração do Imposto sobre a Renda e da Contribuição Social sobre o Lucro Líquido $^{258}$. Assim, assumindo que a dedutibilidade dos JSCP será determinada à alíquota total de aproximadamente $34 \%$ (trinta e quatro por cento) ${ }^{259}$, pode-se afirmar que o benefício tributário efetivo decorrente do seu pagamento é de 19\% (dezenove por cento). Not-se que esse percentual considera a carga efetiva incidente sobre o pagamento desses juros aplicável tanto no nível dos sócios como da sociedade.

Ainda que o benefício efetivo do pagamento dos JSCP seja de 19\% (dezenove por cento), pode-se afirmar que, de forma direta, ele está localizado no nível da sociedade beneficiária da dedutibilidade prevista na Lei $\mathrm{n}^{\circ}$ 9.249/95. De forma indireta, entretanto, ele atinge o nível dos sócios por meio da maior lucratividade da sociedade, decorrente da redução da carga tributária a ela aplicável.

No caso dos dividendos, o benefício da isenção tributária é diretamente aplicado aos sócios, sem qualquer efeito direto ou indireto (ao menos imediato) no nível da sociedade.

À sociedade é concedida, ainda, a possibilidade de imputar o valor dos JSCP ao valor dos dividendos obrigatoriamente devidos pela sociedade nos termos do já analisado artigo 202 da Lei das Sociedades Anônimas - Lei nº 6.404/76. Nesse caso, o parágrafo $7^{\circ}$ do artigo $9^{\circ}$, da Lei $n^{\circ} 9.249 / 95$, expressamente assegura a manutenção da dedutibilidade dos juros para a sociedade.

\footnotetext{
${ }^{257}$ Parágrafos $9^{\circ}$ e $10^{\circ}$ do artigo $9^{\circ}$ da Lei $n^{\circ} 9.249 / 95$.

${ }^{258}$ Artigo $9^{\circ}$ da Lei $n^{\circ}$ 9.249/95 e Artigo 347 do Regulamento do Imposto sobre a Renda - Decreto 3.000/99. A permissão para a dedução dos JSCP da base de cálculo da Contribuição Social sobre o Lucro não consta da Lei $n^{\circ} 9.249 / 95$, mas da Lei $n^{\circ} 9.430 / 96$, que revogou o parágrafo $10^{\circ}$ do artigo $9^{\circ}$ da lei de 1995 , que previa, em sua redação original, que esses juros seriam indedutíveis para fins de cálculo dessa contribuição.

${ }^{259}$ Para esses fins, estamos assumindo que as sociedades são tributadas pelo Imposto sobre a Renda à alíquota de $25 \%$ e pela Contribuição Social sobre o Lucro Líquido à alíquota de $9 \%$.
} 
Essa regra pode ser vista como mais uma confirmação da opinião exposta no item 2 acima quanto aos motivos que incentivaram a criação dos JSCP nos termos da Lei $\mathbf{n}^{\mathbf{o}}$ 9.249/95. A equiparação de tratamento tributário entre as remunerações do capital de terceiros e do capital próprio possuía, como um dos requisitos, a previsão de dedutibilidade na remuneração de sócios. Assim, conforme será analisado em detalhes ainda neste Capítulo, os JSCP podem ser vistos como a forma de cálculo encontrada para justificar a dedutibilidade de ao menos parte da remuneração do capital próprio, parte esta correspondente ao seu custo de oportunidade.

\subsection{O tratamento contábil dispensado aos juros sobre o capital próprio pela regulamentação da Comissão de Valores Mobiliários - CVM}

Conforme visto no item 3 acima, a legislação tributária determina que, em contrapartida ao valor dos JSCP lançados no passivo exigível da sociedade pagadora, deverá ser registrada uma despesa financeira no período correspondente.

Todavia, a Comissão de Valores Mobiliários - CVM - editou a Deliberação $n^{\circ}$ 207/96, que dispõe especificamente sobre a contabilização dos JSCP no caso de pagamento por sociedades anônimas de capital aberto. De acordo com o item I da referida deliberação, a contrapartida do valor dos JSCP lançados no passivo exigível da sociedade deve ser debitada diretamente à conta de lucros acumulados, sem afetar o resultado do exercício ${ }^{260}$.

Da mesma forma, pela legislação tributária, os JSCP são tratados como receita financeira no nível do sócio, enquanto a Comissão de Valores Mobiliários - CVM, diferentemente, prevê duas hipóteses nas quais esses juros deverão ser lançados a crédito na conta de investimento, assim como previsto para os dividendos recebidos em relação a investimentos avaliados pelo método da equivalência patrimonial.

Segundo o item II, 'a', da Deliberação da Comissão de Valores Mobiliários CVM n 207/96, essa forma de contabilização se aplica apenas aos juros cujo valor ainda faça parte do patrimônio líquido da empresa investida ou já tenha sido computado no valor pago pela aquisição do investimento. Apenas nos demais casos os JSCP devem ser contabilizados como despesa.

\footnotetext{
${ }^{260}$ Nessa hipótese, a sociedade deverá realizar o devido ajuste no Livro de Apuração do Lucro Real LALUR.
} 
Ainda que o tratamento contábil dispensado por cada uma dessas normas possua implicações opostas, a previsão de normas diversas para a contabilização dos juros não deve ser vista com surpresa.

A referida deliberação da Comissão de Valores Mobiliários - CVM - visa evitar que, para fins comparativos, o lucro corrente de uma companhia (o qual é um relevante medidor de desempenho das sociedades) seja afetado pelo pagamento de JSCP. Conforme ensina Ariovaldo dos Santos e Fabiana Lopes da Silva, diante do fato de o pagamento dos JSCP ser uma faculdade, na prática, "a comparabilidade de resultados da própria empresa, de um exercício para o outro, e entre empresas, pode ficar bastante difícil e até impossivel de ser efetuada"261.

Além disso, a própria deliberação da Comissão de Valores Mobiliários - CVM estabelece expressamente, em seu item VII, que essas regras contábeis não implicam alteração ou interpretação das disposições de natureza tributária. E, ainda, prevê que a companhia poderá optar por realizar a contabilização desses valores em conformidade com as regras tributárias. Nesse último caso, entretanto, a companhia deve proceder à reversão desses valores, nos registros mercantis, de forma que o lucro líquido ou o prejuízo do exercício seja apurado nos termos da deliberação da Comissão de Valores Mobiliários CVM.

Sendo assim, no caso de sociedades anônimas de capital aberto, o procedimento adequado é contabilizar o valor a ser pago como JSCP diretamente à conta de lucros acumulados, realizando o ajuste necessário nos livros fiscais ${ }^{262}$ da sociedade para que ocorra a dedutibilidade de referidas despesas no próprio período de apuração dos juros. Da mesma forma, no nível da beneficiária, o valor dos JSCP deve ser contabilizado na conta de investimento, quando for o caso, e, para fins fiscais, deve ser realizado o devido ajuste.

\footnotetext{
${ }^{261}$ SANTOS, Ariovaldo dos; SILVA, Fabiana Lopes da. Aspectos práticos da demonstração do valor adicionado - distribuição de lucros (juros sobre o capital próprio e dividendos) e doações e subvenções para investimentos. ( $1^{\mathrm{a}}$ parte). IOB: informações objetivas. Temática Contábil e Balanços, São Paulo, v. 37, n. 15 , p. 2 e 9 , abr. 2003.

${ }^{262}$ Livro de apuração do lucro real - LALUR.
} 


\subsection{O cálculo dos juros sobre o capital próprio e as controvérsias decorrentes da legislação vigente}

Ao determinar as condições para a dedutibilidade dos valores pagos ou creditados a título de JSCP, a legislação regulou a forma de cálculo desses juros e as condições para o seu pagamento ${ }^{263}$.

Conforme mencionado anteriormente, os JSCP são calculados por meio da aplicação da Taxa de Juros a Longo Prazo - TJLP $^{264}$ sobre as contas do patrimônio líquido da sociedade ${ }^{265}$.

Para esses fins, o valor do patrimônio líquido a ser adotado deve ser diminuído do valor da reserva de reavaliação de bens ou direitos, quando existente. Exceção a essa regra é o caso em que a referida reserva é adicionada na determinação da base de cálculo do Imposto sobre a Renda e da Contribuição Social sobre o Lucro Líquido ${ }^{266}$.

Ainda que sem previsão na legislação ordinária, a Instrução Normativa da Secretaria da Receita Federal no $11 / 96^{267}$ ampliou a lista das parcelas a serem excluídas do patrimônio líquido da sociedade para fins de cálculo dos JSCP. Além da reserva de reavaliação de bens e direitos da sociedade, segundo a referida instrução normativa, também deverão ser deduzidos os valores (i) da reserva especial de que trata o artigo 428 do Regulamento do Imposto sobre a Renda de 1994 - Decreto $\mathrm{n}^{\circ} 1.041 / 94^{268}$; (ii) da

\footnotetext{
${ }^{263}$ É importante ressaltar que, apesar de as normas gerais sobre o assunto estarem previstas no artigo $9^{\circ}$ da Lei $n^{\circ}$ 9.249/95, especificidades necessárias ao cálculo e à contabilização desses juros estão previstas em instruções normativas e atos declaratórios, cuja análise será imprescindível para algumas questões propostas neste trabalho.

${ }^{264} \mathrm{O}$ valor da Taxa de Juros a Longo Prazo - TJLP, a ser aplicada, deverá ser calculada pro rata dia.

${ }^{265}$ Artigo $9^{\circ}$, caput, da Lei $\mathrm{n}^{\circ} 9.249 / 95$ e Artigo 347, caput, do Regulamento do Imposto sobre a Renda Decreto ${ }^{\circ} 3.000 / 99$.

${ }^{266}$ Artigo $9^{\circ}$, parágrafo $8^{\circ}$, da Lei $n^{\circ} 9.249 / 95$ e Artigo 347, parágrafo $4^{\circ}$, do Regulamento do Imposto sobre a Renda - Decreto n ${ }^{\circ} 3.000 / 99$.

267“Artigo 29. Para efeito de apuração do lucro real, observado o regime de competência, poderão ser deduzidos os juros pagos ou creditados individualizadamente a titular, sócios ou acionistas, a título de remuneração do capital próprio, calculados sobre as contas do patrimônio líquido e limitados à variação, pro rata dia, da Taxa de Juros de Longo Prazo - TJLP.

(...)

Parágrafo $2^{\circ}$. Para os fins do cálculo da remuneração prevista neste artigo, não será considerado, salvo se adicionado ao lucro líquido para determinação do lucro real e da base de cálculo da contribuição social sobre o lucro, valor:

a) da reserva de reavaliação de bens e direitos da pessoa jurídica;

b) da reserva especial de trata o art. 428 do RIR/94;

c) da reserva de reavaliação capitalizada nos termos dos arts. 384 e 385 do RIR/94, em relação às parcelas não realizadas. (...)"

${ }^{268}$ Lei $\mathrm{n}^{\circ} 8.200 / 91$, artigo $2^{\circ}$.
} 
reserva de reavaliação capitalizada nos termos dos artigos 384 e 385 do mesmo regulamento, no que se refere às parcelas não realizadas.

A reserva constante do artigo 428 do Regulamento do Imposto sobre a Renda de 1994 - Decreto no 1.041/94 - é a reserva especial decorrente da correção monetária das contas do ativo permanente. Essa regra está atualmente prevista no artigo 460 do Regulamento do Imposto sobre a Renda - Decreto $\mathrm{n}^{\mathbf{0}} 3.000 / 99$, nos mesmos termos daquele artigo do regulamento de 1994.

Por sua vez, as regras constantes dos artigos 384 e 385 do regulamento de 1994 estão integralmente previstas nos artigos 436 e 437 do Regulamento do Imposto sobre a Renda - Decreto $\mathrm{n}^{\mathrm{o}} 3.000 / 99$, que tratam da incorporação ao capital social dos valores registrados na reserva de reavaliação constituída em contrapartida ao aumento de valor de bens imóveis detidos pela sociedade.

Adicionalmente à aplicação da Taxa de Juros a Longo Prazo - TJLP - sobre as contas do patrimônio líquido da sociedade, o efetivo crédito ou pagamento de JSCP está condicionado à existência de lucros ou de reservas de lucros e lucros acumulados, em montante igual ou superior ao valor correspondente a duas vezes o valor dos juros a serem $\operatorname{pagos}^{269}$.

Ou seja, o valor dos JSCP passível de distribuição é limitado a 50\% (cinqüenta por cento) dos lucros acumulados e das reservas de lucros ou a 50\% (cinqüenta por cento) dos lucros do exercício ${ }^{270}$. A legislação deixa a cargo do contribuinte a decisão quanto a qual desses limites aplicar.

Pode-se afirmar, portanto, que a legislação concede ao contribuinte a possibilidade de maximizar o aproveitamento do benefício da dedutibilidade dos JSCP por meio da opção pelo maior valor dentre aqueles correspondentes a $50 \%$ (cinqüenta por cento) dos lucros acumulados e das reservas de lucros e 50\% (cinqüenta por cento) dos lucros do exercício ${ }^{271}$.

\footnotetext{
${ }^{269}$ Artigo $9^{\circ}$, parágrafo $1^{\circ}$, da Lei $n^{\circ} 9.249 / 95$ e Artigo 347, parágrafo $1^{\circ}$, do Regulamento do Imposto sobre a Renda - Decreto $\mathrm{n}^{\circ} 3.000 / 99$.

${ }^{270}$ Para esses fins, o lucro do exercício utilizado deve ser aquele obtido após a dedução da Contribuição Social sobre o Lucro Líquido e antes da dedução do Imposto sobre a Renda e dos JSCP (Artigo $9^{\circ}$, parágrafo $1^{\circ}$, da Lei $n^{\circ}$ 9.249/95; Artigo 347, parágrafo $1^{\circ}$, do Regulamento do Imposto sobre a Renda Decreto no 3.000/99; e Instrução Normativa da Secretaria da Receita Federal no 93/97, artigo 29, parágrafo único).

${ }^{271}$ Artigo 29 da Instrução Normativa da Secretaria da Receita Federal no 93/97.
} 
Resumidamente, portanto, a legislação tributária condiciona o gozo do benefício da dedutibilidade dos JSCP a dois limites quantitativos: (i) $1^{\circ}$ limite: aplicação Taxa de Juros a Longo Prazo - TJLP sobre as contas do patrimônio líquido da sociedade; (ii) $2^{\circ}$ limite: 50\% (cinqüenta por cento) dos lucros acumulados e das reservas de lucros ou 50\% (cinquienta por cento) dos lucros do exercício. Em termos práticos, uma vez calculados os dois limites, a sociedade poderá creditar ou pagar JSCP e aproveitar o benefício de dedutibilidade fiscal até o limite de menor valor.

A legislação não é clara quanto à possibilidade de pagamento de JSCP em valor superior àquele obtido por meio da aplicação dos referidos limites. Entretanto, com base na literalidade do parágrafo $1^{\circ}$ do artigo $9^{\circ}$ da Lei $n^{\circ} 9.249 / 95$, pode-se afirmar que o $2^{\circ}$ limite se aplica ao pagamento ou crédito dos JSCP e não à sua dedutibilidade. Isso porque, ao estipular o cálculo do limite referente a $50 \%$ (cinqüenta por cento) dos lucros acumulados e das reservas de lucros ou $50 \%$ (cinqüenta por cento) dos lucros do exercício, esse dispositivo se utiliza dos substantivos pagamento ou crédito e não dedutibilidade ${ }^{272}$.

Nesse sentido, ao regulamentar o crédito ou pagamento de JSCP a sócios residentes no exterior, os artigos $2^{\circ}$ e $5^{\circ}$, da Circular do Banco Central do Brasil $n^{\circ}$ 2.722/96, determinam que esses juros somente podem ser capitalizados ou remetidos ao exterior até o limite previsto na legislação tributária para a sua dedutibilidade.

Entretanto, é importante mencionar que, diante do fato de a criação dessa figura no Direito Positivo Brasileiro buscar conceder a dedutibilidade fiscal ao pagamento de remunerações aos sócios, existem autores que defendem que esses limites legais se aplicam unicamente para fins de dedutibilidade de valores quando do cálculo do Imposto sobre a Renda devido pela sociedade investida, fonte pagadora do benefício.

Esse entendimento é confirmado por Edmar Oliveira Andrade Filho que afirma que os "citados critérios dizem respeito, exclusivamente, à dedução da despesa

\footnotetext{
272“Artigo 90. A pessoa jurídica poderá deduzir, para efeitos da apuração do lucro real, os juros pagos ou creditados individualizadamente a titular, sócios ou acionistas, a título de remuneração do capital próprio, calculados sobre as contas do patrimônio líquido e limitados à variação, pro rata dia, da Taxa de Juros de Longo Prazo - TJLP.

Parágrafo $1^{o}$. O efetivo pagamento ou crédito dos juros fica condicionado à existência de lucros, computados antes da dedução dos juros, ou de lucros acumulados e reservas de lucros, em montante igual ou superior ao valor de duas vezes os juros a serem pagos ou creditados."
} 
correspondente e, em princípio, não impedem que uma sociedade remunere, da forma como melhor lhe aprouver, o capital de seus sócios ou acionistas",273.

De qualquer forma, independentemente da corrente adotada em relação a esse assunto, o valor pago ou creditado em montante superior àquele obtido pela aplicação dos limites legais deveria, ao menos em relação a sócios residentes no país, ser considerado dividendo (se a condição financeira e contábil da sociedade o permitir) ou como rendimentos diversos, sujeito à tributação regular no nível dos sócios.

A legislação aplicável aos JSCP, apesar de simples e clara, deixou a desejar em relação a alguns aspectos do seu cálculo, por exemplo: o valor do patrimônio líquido da sociedade a ser adotado para fins de aplicação da Taxa de Juros a Longo Prazo - TJLP - é aquele apurado no início ou no fim do período de apuração a que se referem os juros? Dependendo da resposta a essa primeira pergunta, podem surgir outras, por exemplo: o valor do lucro exercício deve ser incluído no patrimônio líquido da sociedade a ser utilizado para o cálculo do primeiro limite legal para o pagamento dos JSCP? A seguir, busca-se responder a essas e a outras questões relativas ao cálculo desses juros.

\subsubsection{Juros sobre o capital próprio calculados, creditados e pagos pelo regime de competência}

Em relação ao primeiro limite mencionado para apuração do valor dos JSCP, i.e., aplicação da Taxa de Juros a Longo Prazo - TJLP - sobre as contas do patrimônio líquido da sociedade, a legislação não é clara quanto à obrigatoriedade ou não de inclusão dos lucros do exercício no valor do patrimônio líquido a ser utilizado.

Conforme mencionado no item 3.2. acima, em relação ao valor do patrimônio líquido a ser adotado, a legislação menciona apenas que ele deve ser diminuído do valor da reserva de reavaliação de bens ou direitos da sociedade, quando existente ${ }^{274}$.

Não fica claro, portanto, se o valor do patrimônio líquido a ser considerado para fins de cálculo dos juros deve ser o do próprio período-base em que forem pagos ou

\footnotetext{
${ }^{273}$ ANDRADE FILHO, Edmar Oliveira. Perfil jurídico do juro sobre o capital próprio: IRPJ, CSLL, PIS, COFINS - aspectos societários. São Paulo: MP Ed., 2006. p. 37. No mesmo sentido, veja ANAN JÚNIOR, Pedro. op. cit., p. 318.

${ }^{274}$ Para facilitar o entendimento do leitor, foram desconsideradas as previsões da Instrução Normativa da Secretaria da Receita Federal no 11/96, comentada em detalhes no item 3.2. deste Capítulo.
} 
creditados, ou se os JSCP devem ser calculados sobre o valor do patrimônio líquido registrado ao final do exercício fiscal imediatamente anterior.

Nos termos do artigo 177 da Lei das Sociedades Anônimas - Lei no 6.404/76 ${ }^{275}$, a escrituração das mutações patrimoniais da sociedade deverá ser realizada segundo o regime de competência. Como não poderia ser diferente, a legislação fiscal ${ }^{276}$ confirma $^{2}$ essa disposição da lei societária ${ }^{277}$.

Segundo o regime de competência, regra geral aplicável a todas as pessoas jurídicas $^{278}$, as receitas e despesas devem ser apropriadas nos respectivos períodos, em função do momento de sua ocorrência, independentemente de seus reflexos no caixa da sociedade $^{279}$. Em outras palavras, as receitas devem ser registradas no período no qual se deu o fato que propiciou a sua geração, independentemente do seu efetivo ingresso no caixa da sociedade. Da mesma forma, as despesas devem ser apropriadas no período em que foram incorridas, mesmo que ainda não tenham representado a diminuição real do caixa da sociedade. Sobre esse regime, vale mencionar a lição de Bulhões Pedreira:

"O objetivo do regime de competência é distribuir o resultado da sociedade empresária entre os exercícios sociais, segundo critério que atribua a cada período o resultado que lhe compete, ou cabe, em termos de lucro ganho no período ou prejuízo originário de fato nele incorrido. Esse objetivo é peculiar ao regime de competência: no regime de caixa, as receitas e despesas não são classificadas segundo períodos de tempo, mas registradas exclusivamente em função do recebimento ou pagamento" 280 .

As regras sobre a aplicação desse regime estão previstas na Resolução do Conselho Federal de Contabilidade $n^{\circ} 750 / 93$, que dispõe sobre os princípios fundamentais de contabilidade. Ao tratar do regime de competência, o artigo $9^{\circ}$ dessa resolução determina que, nos casos em que as despesas e as receitas forem relacionadas, o seu

\footnotetext{
275“'Artigo 177. A escrituração da companhia será mantida em registros permanentes, com obediência aos preceitos da legislação comercial e desta Lei e aos princípios de contabilidade geralmente aceitos, devendo observar métodos ou critérios contábeis uniformes no tempo e registrar as mutações patrimoniais segundo o regime de competência".

${ }^{276}$ Decreto-Lei $\mathrm{n}^{\circ} 1.598 / 77$, artigo $6^{\circ}$, parágrafo $5^{\circ}$; e artigos 251 e 273 do Regulamento do Imposto sobre a Renda - Decreto no 3.000/99.

${ }^{277}$ Especialmente em relação aos JSCP, a Instrução Normativa da Secretaria da Receita Federal no $11 / 96$ prevê, em seu artigo 29, que o regime de competência deverá ser observado para a sua dedutibilidade.

${ }^{278} \mathrm{Em}$ casos específicos, a legislação tributária vigente dá margem à adoção do regime de caixa exclusivamente para fins de cálculo e recolhimento de tributos federais. Essa possibilidade se aplica, regra geral, a sociedades tributadas pelo Imposto sobre a Renda com base no regime de lucro presumido, as quais desenvolvem atividades listadas na legislação, como é o caso das sociedades imobiliárias.

${ }^{279}$ IUDÍCIBUS, Sérgio de; MARTINS, Eliseu; GELBCKE, Ernesto Rubens. op. cit., p. 8.

${ }^{280}$ PEDREIRA, José Luiz Bulhões. op. cit., p. 487-488.
} 
registro deve se dar simultaneamente, independentemente do seu pagamento ou recebimento.

Adotando essa mesma lógica para o cálculo dos JSCP, todos os parâmetros previstos na legislação para o seu cálculo deverão ser referentes ao mesmo período de apuração. Assim, pela aplicação do regime de competência ao pagamento ou crédito dos JSCP, pode-se afirmar que a Taxa de Juros a Longo Prazo - TJLP - deve ser aplicada sobre o valor do patrimônio líquido do exercício a que se referem os juros. Da mesma forma, a Taxa de Juros a Longo Prazo - TJLP - também deve ser aquela referente ao período de apuração dos juros. Se os juros são referentes ao exercício de 2008, por exemplo, a Taxa de Juros a Longo Prazo - TJLP - a ser adotada, deverá ser aquela acumulada durante todo esse ano-calendário e o patrimônio líquido também deverá ser aquele verificado ao final desse exercício.

A utilização de valor de patrimônio líquido diverso daquele do período de apuração dos JSCP implicaria a dedutibilidade de despesas calculadas em base não contemporânea, o que, quanto ao exercício de apuração do Imposto sobre a Renda, poderia resultar na dedutibilidade de juros calculados sobre patrimônio líquido fictício.

A própria Receita Federal do Brasil confirma esse entendimento, ao afirmar que a variação da Taxa de Juros a Longo Prazo - TJLP - deve corresponder ao tempo decorrido desde o início do período de apuração até a data do pagamento ou crédito dos juros. Ainda, afirma que a taxa obtida nesses termos deverá ser aplicada sobre o patrimônio líquido, no início desse período, e devidamente ajustado com as variações positivas ou negativas $\underline{\text { ocorridas no seu curso }^{281}}$.

Ainda em relação à adoção do regime de competência para aos JSCP, é importante mencionar a existente discussão quanto à possibilidade de pagamento e dedutibilidade desses juros referentes a exercícios anteriores.

Adotando o mesmo raciocínio utilizado para definir qual o valor de patrimônio líquido que deve ser assumido para o cálculo dos JSCP, a conclusão a essa questão deveria ser, em princípio, pela vedação ao seu pagamento ou dedutibilidade. Se esses juros são calculados sobre os valores de patrimônio líquido, Taxa de Juros a Longo Prazo - TJLP,

\footnotetext{
${ }^{281}$ Perguntas e respostas da Receita Federal do Brasil em relação à Declaração de Informações EconômicoFiscais da Pessoa Jurídica - DIPJ. MINISTÉRIO DA FAZENDA. Receita Federal. Disponível em: <http://www.receita.fazenda.gov.br/publico/perguntao/dipj2008/Capítulo\%20VIII\%20-

\%20Lucro\%20Operacional\%202008.pdf >. Acesso em: 04 jan. 2009.
} 
lucros acumulados e lucros do exercício referentes a determinado exercício, a dedutibilidade da despesa com o seu pagamento ou crédito deveria ser registrada nesse mesmo período.

Entretanto, a nosso ver, esse posicionamento não leva em conta algumas especificidades previstas no próprio artigo $9^{\circ}$, da Lei $n^{\circ}$ 9.249/95. Segundo o caput desse artigo, a dedutibilidade dos JSCP para fins fiscais depende do seu efetivo pagamento ou crédito aos sócios, conforme segue.

“Artigo $9^{\circ}$. A pessoa jurídica poderá deduzir, para efeito da apuração do lucro real, os juros pagos ou creditados individualizadamente a titular, sócios ou acionistas, a título de remuneração do capital próprio, calculados sobre as contas do patrimônio líquido e limitados à variação, pro rata dia, da Taxa de Juros de Longo Prazo - TJLP." (grifos nossos)

Além das limitações quantitativas já analisadas no item 3.2. deste Capítulo, a dedutibilidade dos JSCP também está condicionada ao cumprimento de um requisito de ordem temporal, qual seja, o seu efetivo pagamento ou crédito ${ }^{282}$. Cumpridos esses dois requisitos, os juros devem ser totalmente dedutíveis.

Assim, desde que calculados com base em patrimônio líquido, Taxa de Juros a Longo Prazo - TJLP, lucros acumulados e lucros do exercício correspondentes a cada um dos períodos de apuração, não há justificativa para a vedação ao pagamento dos JSCP relativos a exercícios anteriores, uma vez que a concretização de todos os requisitos necessários à sua dedutibilidade será verificada apenas no momento do seu crédito ou pagamento.

É importante ressaltar que a regra constante do artigo 29 da Instrução Normativa da Secretaria da Receita Federal no 11/96 não altera esse entendimento. Segundo referido dispositivo, a dedução dos JSCP para efeito de apuração do lucro real deverá observar o regime de competência. Ora, se as condições legais para a dedutibilidade fiscal dos juros relativos a exercícios anteriores são cumpridas apenas no momento do seu pagamento ou crédito, com base no próprio regime de competência é que se afirma que esse é também o momento de considerar o seu valor dedutível para fins fiscais. O regime de competência não deixa de ser cumprido pelo simples fato de o momento do pagamento da despesa ser o mesmo daquele em que se torna possível a sua dedutibilidade.

\footnotetext{
${ }^{282}$ Nesse mesmo sentido, veja ANAN JÚNIOR, Pedro. op. cit., p. 317.
} 


\subsubsection{A exclusão do lucro do exercício do valor do patrimônio líquido a ser utilizado para o cálculo dos juros sobre o capital próprio}

Superada a questão quanto ao valor do patrimônio líquido que deve ser utilizado para o cálculo dos JSCP, surge a questão sobre se o lucro do exercício deve ou não ser incluído nas contas do patrimônio líquido para efeito de cálculo desses juros.

Conforme mencionado anteriormente nos itens 3.2. e 3.2.1. deste Capítulo, ao definir o patrimônio líquido a ser utilizado para o cálculo dos JSCP, o artigo $9^{\circ}$, da Lei $\mathrm{n}^{\circ}$ $9.249 / 95$, determina apenas a exclusão de eventual reserva de reavaliação não realizada ${ }^{283}$.

Segundo o artigo 178, parágrafo 2º alínea 'd', da Lei das Sociedades Anônimas Lei $\mathrm{n}^{\mathrm{o}}$ 6.404/76, o patrimônio líquido é dividido nas seguintes contas: capital social, reservas de capital, ajustes de avaliação patrimonial, reservas de lucros, ações em tesouraria e prejuízos acumulados ${ }^{284}$. Não há referência sobre a existência de conta de lucros ou prejuízos do exercício, uma vez que tais contas devem fazer parte dos lucros ou prejuízos acumulados nos termos do artigo 186 da mesma lei ${ }^{285}$.

Assim, com base na legislação societária, pode-se afirmar que os lucros do exercício devem ser incluídos no valor do patrimônio líquido da sociedade para fins de cálculo dos JSCP.

No entanto, sob ponto de vista da prática contábil, os lucros do exercício que não foram distribuídos são transferidos para a conta de lucros acumulados apenas quando do encerramento do período de apuração ${ }^{286}$. Com base nesse procedimento, a Receita Federal

\footnotetext{
${ }^{283}$ Adicionalmente, o parágrafo $2^{\circ}$ do art. 29 da Instrução Normativa da Secretaria da Receita Federal $\mathrm{n}^{\mathrm{o}}$ 11/96 amplia as exclusões das contas de patrimônio líquido, dispondo que "para fins do cálculo da remuneração prevista neste artigo, não será considerado, salvo se adicionado ao lucro líquido para determinação do lucro real e da base de cálculo da contribuição social sobre o lucro, valor:

a) da reserva de reavaliação de bens e direitos da pessoa jurídica;

b) da reserva especial de trata o art. 428. do RIR/94;

c) da reserva de reavaliação capitalizada nos termos dos arts. 384 e 385 do RIR/94, em relação às parcelas não realizadas..

${ }^{284}$ É importante mencionar que essa estruturação do patrimônio líquido da sociedade foi introduzida pela Lei $\mathrm{n}^{\mathrm{o}} 11.638 / 07$. Anteriormente a sua publicação, o patrimônio líquido era dividido em capital social, reservas de capital, reservas de reavaliação, reservas de lucros e lucros ou prejuízos acumulados.

285 “Artigo 186. A demonstração de lucros ou prejuízos acumulados discriminará:

I. O saldo do início do período, os ajustes de exercícios anteriores e a correção monetária do saldo inicial; II. As reversões de reservas e o lucro líquido do exercício;

III. As transferências para reservas, os dividendos, a parcela dos lucros incorporada ao capital e o saldo ao fim do período."

${ }^{286}$ Parecer Normativo do Coordenador do Sistema de Tributação - CST no 20/87, item 3.3. Nesse mesmo sentido, veja ANDRADE FILHO, Edmar Oliveira. op. cit., p. 41.
} 
do Brasil entende que o lucro do próprio período de apuração não deve ser computado como integrante do patrimônio líquido para fins de cálculo dos $\mathrm{JSCP}^{287}$.

\subsubsection{A necessidade de compensação de prejuízos acumulados para o pagamento de juros sobre o capital próprio}

Conforme analisado acima no item 3.2. deste Capítulo, o efetivo crédito ou pagamento de JSCP está limitado a (i) 50\% dos lucros acumulados; ou (ii) 50\% do lucro líquido do exercício, após a dedução da Contribuição Social sobre o Lucro Líquido e antes da dedução desses juros e da provisão para o Imposto sobre a Renda.

Nos termos do artigo 189 da Lei das Sociedades Anônimas - Lei nº 6.404/76, antes de qualquer participação, os prejuízos acumulados deverão ser deduzidos do resultado do exercício. Aplicando essa regra ao limite previsto para o pagamento ou crédito dos JSCP, tem-se que, para a definição do valor correspondente a 50\% do lucro líquido do exercício, deverão ser necessariamente abatidos os prejuízos acumulados eventualmente existentes.

Com base nesse entendimento, o Banco Central do Brasil apresenta empecilhos para a efetivação de remessa ao exterior a título de JSCP quando a sociedade brasileira, embora possua lucros do exercício suficientes para o pagamento ${ }^{288}$, apresenta prejuízos de exercícios anteriores $^{289}$.

Especificamente em relação ao cálculo dos JSCP, o Ato Declaratório Normativo do Coordenador-geral do Sistema de Tributação - COSIT no 13/96, contrariando o disposto no artigo 189, da Lei das Sociedades Anônimas - Lei no 6.404/76, prevê que o valor do lucro líquido a ser adotado deve ser aquele correspondente ao período-base do seu pagamento ou crédito, antes da provisão para o Imposto sobre a Renda e da dedução dos referidos juros. Para esse normativo, portanto, o valor do lucro do exercício a ser

\footnotetext{
${ }^{287}$ Perguntas e respostas da Receita Federal do Brasil em relação à Declaração de Informações Econômicofiscais da Pessoa Jurídica - DIPJ. MINISTÉRIO DA FAZENDA. Receita Federal. Disponível em: <http://www.receita.fazenda.gov.br/publico/perguntao/dipj2008/Capítulo\%20VIII\%20\%20Lucro\%20Operacional\%202008.pdf >. Acesso em: 04 jan. 2009.

${ }^{288}$ Respeitando-se ainda o limite referente à aplicação da TJPL sobre as contas de patrimônio líquido.

${ }^{289}$ Esse entendimento decorre da prática adotada pelo Banco Central do Brasil, uma vez que não existe normativo dessa instituição que expressamente confirme essa informação.
} 
considerado não deve ser reduzido por eventual prejuízo acumulado decorrente de anos anteriores.

Ainda que a regra prevista nesse normativo seja divergente daquela prevista na legislação societária, ela está em conformidade com o tratamento tributário dispensado aos JSCP, que trata essa figura como rendimento ou despesa financeira.

Sobre esse assunto, vale ressaltar que a legislação societária citada, ao definir lucro líquido como aquele depois de deduzidos eventuais prejuízos acumulados, está se referindo a distribuições de dividendos ou outras destinações de lucros, contexto em que está inserida. Assim, a sua aplicação pelo Banco Central do Brasil para fins de controle cambial não é congruente com a posição adotada pelo Governo para fins fiscais.

Isso revela um grande absurdo, uma vez que as diretrizes adotadas pelo Banco Central do Brasil são determinadas pelo Conselho Monetário Nacional ${ }^{290}$, conselho este formado por membros do executivo e presidido pelo próprio Ministro da Fazenda ${ }^{291}$, que também comanda as políticas fiscais do país. Nada mais incongruente, portanto, do que existirem dois posicionamentos diversos, sobre o mesmo assunto, no âmbito de um só governo.

Aliás, a nosso ver, o Banco Central do Brasil, como autoridade monetária do Governo Brasileiro, não possui discricionariedade para limitar a remessa de JSCP ao exterior nos casos em que a empresa brasileira apresenta prejuízos acumulados. A Lei $\mathrm{n}^{\circ}$ 4.595/64, que criou o Banco Central do Brasil como autarquia federal integrante do Sistema Financeiro Nacional, lista taxativamente, em seus artigos 10 e 11, todas as competências dessa instituição, as quais não englobam a regulamentação dos incentivos de cunho econômico para a aplicação de capital estrangeiro no País via investimento direto, como é o caso dos JSCP instituídos nos termos da Lei no 9.249/95.

Ainda, a Lei $n^{\circ} 4.595 / 64$, ao prever a competência dessa instituição para efetuar o controle dos capitais estrangeiros, menciona expressamente que deverá fazê-lo nos termos da lei, sem deixar margem para que o Banco Central do Brasil imponha limites adicionais àqueles já previstos pela legislação tributária.

\footnotetext{
${ }^{290}$ Artigo $9^{\circ}$ da Lei ${ }^{\circ} 4.595 / 64$.

${ }^{291}$ Artigo $6^{\circ}$, inciso I, da Lei ${ }^{\circ}$ 4.595/64.
} 
3.2.4. As implicações decorrentes da existência de conflito de regramentos no valor dos juros sobre o capital próprio passível de pagamento

Conforme demonstrado acima, existem diversas controvérsias acerca do cálculo dos JSCP, principalmente no que se refere às diferenças decorrentes de normas societárias e tributárias conflitantes.

Seguem abaixo exemplos numéricos, que exemplificam as duas formas de cálculo e demonstram claramente a diferença no valor final de JSCP obtido quando se utiliza cada uma das diferentes normas ${ }^{292}$. Para tanto, são propostos dois cenários diversos: sociedade com resultado negativo no período de apuração e sociedade com resultado positivo no período de apuração. Dentro de cada um desses cenários, existem duas planilhas, nas quais o cálculo dos JSCP foi elaborado com base nos dois regramentos existentes sobre o assunto, i.e., o societário e o tributário.

\section{$\underline{\text { Sociedade com prejuízos no exercício }}$}

Exemplo prático elaborado nos termos da legislação societária vigente

\begin{tabular}{|l|l|l|l|}
\hline & Exemplo 1 & Exemplo 2 & Exemplo 3 \\
\hline Taxa de Juros de Longo Prazo - TJLP & $10 \%$ & $10 \%$ & $10 \%$ \\
\hline Patrimônio Líquido & $\$ 105.000$ & $\$ 125.000$ & $\$ 90.000$ \\
\hline Capital Social & $\$ 100.000$ & $\$ 100.000$ & $\$ 100.000$ \\
\hline Lucros ou prejuízos acumulados & $\$ 5.000$ & $\$ 25.000$ & $(\$ 10.000)$ \\
\hline Resultado do Período & $(\$ 10.000)$ & $(\$ 10.000)$ & $(\$ 10.000)$ \\
\hline $\begin{array}{l}\mathbf{1}^{\mathbf{0}} \text { limite: aplicação da Taxa de Juros de } \\
\text { pongo Prazo - TJLP - sobre o valor do }\end{array}$ & $\$ 9.500$ & $\$ 11.500$ & $\$ 8.000$ \\
\hline $\mathbf{2}^{\mathbf{0}}$ limite: $50 \%$ dos lucros do exercício & - & - & - \\
\hline $\mathbf{2}^{\mathbf{o}}$ limite: $50 \%$ dos lucros acumulados & - & $\$ 7.500$ & - \\
\hline JSCP & - & $\$ 7.500$ & - \\
\hline
\end{tabular}

\footnotetext{
${ }^{292}$ Para esses fins, foram adotadas premissas fixas para os valores de patrimônio líquido, Taxa de Juros a Longo Prazo - TJLP, lucros acumulados e lucros do exercício.
} 
Exemplo prático elaborado conforme regras tributárias vigentes

\begin{tabular}{|l|l|l|l|}
\hline & Exemplo 1 & Exemplo 2 & Exemplo 3 \\
\hline Taxa de Juros de Longo Prazo - TJLP & $10 \%$ & $10 \%$ & $10 \%$ \\
\hline Patrimônio Líquido & $\$ 105.000$ & $\$ 125.000$ & $\$ 90.000$ \\
\hline Capital Social & $\$ 100.000$ & $\$ 100.000$ & $\$ 100.000$ \\
\hline Lucros ou prejuízos acumulados & $\$ 5.000$ & $\$ 25.000$ & $(\$ 10.000)$ \\
\hline Resultado do Período & $(\$ 10.000)$ & $(\$ 10.000)$ & $(\$ 10.000)$ \\
\hline $\begin{array}{l}\mathbf{1}^{\mathbf{o}} \text { limite: aplicação da Taxa de Juros de } \\
\text { Longo Prazo - TJLP - sobre o valor do }\end{array}$ & $\$ 10.500$ & $\$ 12.500$ & $\$ 9.000$ \\
\hline $\mathbf{2}^{\mathbf{0}}$ limite: 50\% dos lucros do exercício & - & - & - \\
\hline $\mathbf{2}^{\mathbf{0}}$ limite: 50\% dos lucros acumulados & $\$ 2.500$ & $\$ 12.500$ & - \\
\hline JSCP & $\$ \mathbf{2 . 5 0 0}$ & $\mathbf{\$ 1 2 . 5 0 0}$ & - \\
\hline
\end{tabular}

Sociedade com lucros no exercício

Exemplo prático elaborado nos termos da legislação societária vigente

\begin{tabular}{|l|l|l|l|}
\hline & Exemplo 1 & Exemplo 2 & Exemplo 3 \\
\hline Taxa de Juros de Longo Prazo - TJLP & $10 \%$ & $10 \%$ & $10 \%$ \\
\hline Patrimônio Líquido & $\$ 105.000$ & $\$ 125.000$ & $\$ 90.000$ \\
\hline Capital Social & $\$ 100.000$ & $\$ 100.000$ & $\$ 100.000$ \\
\hline Lucros ou prejuízos acumulados & $\$ 5.000$ & $\$ 25.000$ & $(\$ 10.000)$ \\
\hline Resultado do Período & $\$ 10.000$ & $\$ 10.000$ & $\$ 10.000$ \\
\hline $\begin{array}{l}\mathbf{1}^{\mathbf{o}} \text { limite: aplicação da Taxa de Juros de } \\
\text { Longo Prazo - TJLP - sobre o valor do } \\
\text { patrimônio líquido }\end{array}$ & $\$ 11.500$ & $\$ 13.500$ & $\$ 10.000$ \\
\hline $\mathbf{2}^{\mathbf{o}}$ limite: 50\% dos lucros do exercício & $\$ 5.000$ & $\$ 5.000$ & $\$ 5.000$ \\
\hline $\mathbf{2}^{\mathbf{o}}$ limite: 50\% dos lucros acumulados & $\$ 7.500$ & $\$ 17.500$ & - \\
\hline JSCP & $\mathbf{\$ 7 . 5 0 0}$ & $\$ 13.500$ & $\$ \mathbf{5 . 0 0 0}$ \\
\hline
\end{tabular}


Exemplo prático elaborado conforme regras tributárias vigentes

\begin{tabular}{|l|l|l|l|}
\hline & Exemplo 1 & Exemplo 2 & Exemplo 3 \\
\hline Taxa de Juros de Longo Prazo - TJLP & $10 \%$ & $10 \%$ & $10 \%$ \\
\hline Patrimônio Líquido & $\$ 105.000$ & $\$ 125.000$ & $\$ 90.000$ \\
\hline Capital Social & $\$ 100.000$ & $\$ 100.000$ & $\$ 100.000$ \\
\hline Lucros ou prejuízos acumulados & $\$ 5.000$ & $\$ 25.000$ & $(\$ 10.000)$ \\
\hline Resultado do Período & $\$ 10.000$ & $\$ 10.000$ & $\$ 10.000$ \\
\hline $\begin{array}{l}\mathbf{1}^{\mathbf{o}} \text { limite: aplicação da Taxa de Juros de } \\
\text { patrimônio líquido }\end{array}$ & $\$ 10.500$ & $\$ 12.500$ & $\$ 9.000$ \\
\hline $\mathbf{2}^{\mathbf{0}}$ limite: 50\% dos lucros do exercício & $\$ 5.000$ & $\$ 5.000$ & $\$ 5.000$ \\
\hline $\mathbf{2}^{\mathbf{0}}$ limite: 50\% dos lucros acumulados & $\$ 2.500$ & $\$ 12.500$ & - \\
\hline JSCP & $\$ \mathbf{5 . 0 0 0}$ & $\$ 12.500$ & $\$ \mathbf{5 5 . 0 0 0}$ \\
\hline
\end{tabular}

4. A causa do financiamento por meio de capital próprio e a definição da natureza jurídica dos juros sobre o capital próprio

Conforme visto até aqui, os JSCP criados nos termos da Lei n ${ }^{\circ}$ 9.249/95 destinamse a remunerar os sócios pelo capital próprio investido na sociedade em igualdade de tratamento, sob o ponto de vista fiscal, com a remuneração do capital de terceiros.

Assim como os dividendos, esses juros remuneram o capital próprio investido na sociedade. Prova disso é o fato de os JSCP serem calculados sobre o patrimônio líquido da sociedade, que, conforme visto no Capítulo I, item 2.1., deste trabalho, delimita o valor do capital próprio investido.

A esse argumento, pode-se adicionar o fato de o seu pagamento ou crédito estar sujeito à existência de lucros ou de lucros acumulados, em montante igual ou superior ao valor de duas vezes os juros a serem pagos ou creditados. Da mesma forma, vimos que a distribuição de dividendos também está condicionada à existência de lucros, seja no exercício ou nas contas de lucros acumulados e reservas de capital. Assim, esse requisito para o pagamento de JSCP evidencia a sua natureza de remuneração de sócios, uma vez 
que o fator risco assumido por estes na organização da empresa está presente também no seu cálculo.

Aliás, vale relembrar que a própria Comissão de Valores Mobiliários - CVM, por meio da Deliberação no 207/96, prevê expressamente que a contrapartida do valor dos JSCP lançados no passivo exigível da sociedade deve ser debitada diretamente à conta de lucros acumulados, sem afetar o resultado do exercício ${ }^{293}$.

Não podemos esquecer, também, a possibilidade de imputação dos valores pagos ou creditados a título de JSCP aos dividendos obrigatórios, conforme parágrafo $7^{\circ}$ do artigo $9^{\circ}$ da Lei $n^{\circ} 9.249 / 95$.

Com base nesses fundamentos é que autores como Heleno Taveira Tôrres ${ }^{294}$, Rachel Sztajn ${ }^{295}$, Alberto Xavier ${ }^{296}$ e Fábio Ulhôa Coelho ${ }^{297}$ afirmam que os JSCP têm natureza de remuneração de sócios. Esses autores, entretanto, expressamente distinguem a figura dos JSCP da figura dos dividendos. Para tanto, argumentam que tanto os JSCP como os dividendos possuem regimes tributário e contábil específicos, os quais foram exaustivamente analisados no presente trabalho. Além disso, conforme visto nos Capítulos I e II, diferentemente dos JSCP, os dividendos possuem extensa regulamentação societária sobre a forma de apuração, proposta de distribuição, aprovação etc, a qual não é integralmente aplicável aos juros em questão.

Concordamos com a opinião desses autores, não apenas em virtude da existência de tratamento tributário e contábil específico dispensado aos JSCP, mas também em

\footnotetext{
${ }^{293}$ Veja item 3.1. do Capítulo III deste trabalho.

294، "Juros sobre o Capital Próprio, não é mais do que uma modalidade de distribuição de resultados, com natureza atípica de 'dividendos' (...)” (TÔRRES, Heleno Taveira. Juros sobre capital próprio - autonomia privada nos investimentos societários e suas implicações em matéria tributária, cit., p. 377).

295،(...) 'juros sobre capital próprio' visa remunerar o investidor sem que incidam todos os tributos exigíveis sobre distribuição de dividendos o que, porém não desnatura sua natureza jurídica de remuneração do investidor. A pretensa equiparação a juros pagos a terceiros, estes sim 'doadores temporários' de recursos os quais serão, em momento posterior, devolvidos pelo tomador é equivocada" (SZTAJN, Rachel; PELIZZARO, Renato S. Juros sobre capital próprio. Revista de direito Mercantil, Industrial, Econômico e Financeiro, São Paulo, v. 145, p. 251, 2007).

296“ 'O 'juro sobre o capital próprio' outra coisa não é que um resultado distribuível da companhia sujeito a regime fiscal especial". XAVIER, Alberto. Natureza jurídico-tributária dos "juros sobre o capital próprio" face à lei interna e aos tratados internacionais. Revista Dialética de Direito Tributário, São Paulo, n. 21, p. 8 , jun. 1997. Vale mencionar que, ao definir a natureza jurídica dos JSCP como resultado distribuível da companhia, esse autor afirma que, quando distribuídos aos sócios, esses valores devem ser tratados como dividendos. Assim, pode-se argumentar que, na opinião desse autor, os JSCP possuem natureza diversa dos dividendos, apenas enquanto não distribuídos.

${ }^{297 ،}$ 'Os juros sobre o capital próprio não podem ser considerados espécie de dividendos. Se os primeiros podem ser imputados a últimos, como prevê a lei, então isso já demonstra tratar-se de institutos diversos. (...) Os juros sobre o capital próprio, com certeza, são um tipo de remuneração dos acionistas" COELHO, Fábio Ulhôa. op. cit., v. 2, p. 344.
} 
virtude do fato de a imputação desses juros ao valor dos dividendos obrigatórios ser uma faculdade e não uma imposição legal. Ou seja, ainda que o pagamento ou o crédito de JSCP esteja sujeito à existência de lucros do exercício ou de lucros acumulados, o valor devido ou pago ao sócio será deduzido dessas contas apenas nos casos abrangidos pela Deliberação da Comissão de Valores Mobiliários - CVM nº 207/96. Conforme visto no item 3.1. deste Capítulo, essa deliberação visa possibilitar a comparabilidade de resultados da própria empresa, de um exercício para o outro e entre empresas.

No Direito Positivo Brasileiro existem, portanto, três formas de remuneração de sócios: distribuição de dividendos, ganho de capital em virtude do aumento do valor patrimonial das participações societárias e JSCP. Nesse sentido, vale mencionar a opinião de Rachel Sztajn e Renato Pelizzaro que, acertadamente, afirmam que "a par dos dividendos, quando declarados, elou ganhos de capital, o investidor brasileiro recebe ainda uma taxa por que, escolhe aplicar fundos diretamente em sociedades que exercem atividades econômicas!",298

É importante mencionar que esse entendimento não é unânime na doutrina sobre o

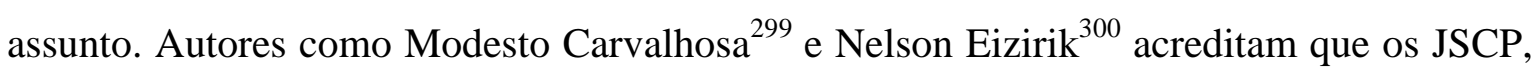
além de serem considerados remuneração de sócios, são, na realidade, espécie de dividendos. Aliás, os argumentos utilizados são exatamente os mesmos expostos acima, exceto pelo fato de afirmarem que a existência de tratamentos contábil e tributário diversos busca apenas satisfazer a política econômica do Estado de incentivar o investimento por meio de capital próprio. Concluem, portanto, que as semelhanças apontadas acima entre os JSCP e os dividendos servem para confirmar que aqueles são espécie de dividendos.

As diferenças entre essas duas linhas de pensamento são tênues e utilizam-se dos mesmos dispositivos legais para fundamentar a sua conclusão. Diferem, entretanto, quanto às implicações decorrentes da existência de regimes contábil e tributário diversos para os JSCP e para os dividendos.

\footnotetext{
${ }^{298}$ SZTAJN, Rachel; PELIZZARO, Renato S. op. cit., p. 251.

299“"Temos, assim, que a Lei $n^{\circ}$ 9.249, de 1995 (art. 9), (...), culminando com a Deliberação no 207, de 13 de dezembro de 1996, da Comissão de Valores Mobiliários, criaram e regulamentaram, no âmbito tributário e societário, o pagamento de juros sobre o patrimônio líquido da companhia aos acionistas, a título de dividendos". CARVALHOSA, Modesto. Comentários à lei de sociedade anônimas: artigos $1^{\circ}$ a 74.4 . ed. São Paulo: Saraiva, 2007. v. 1, p. 216.

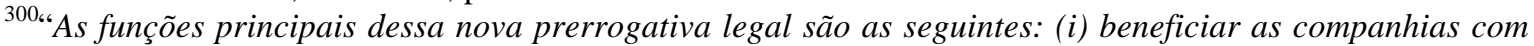
uma parcela de dividendos dedutível do IR (...)". EIZIRIK, Nelson. Reforma das S.A. do mercado de capitais. 2. ed. Rio de Janeiro: Renovar, 1998. p. 56.
} 
Existe, ainda, uma terceira linha de pensamento em relação ao assunto, defendida, dentre outros, por João Dácio Rolim, segundo a qual os JSCP possuem natureza de juros propriamente $\operatorname{ditos}^{301}$. Essa corrente se baseia principalmente em dois diferentes argumentos: (i) os JSCP remuneram o sócio pelo capital investido na sociedade e indisponível, portanto, para a realização de outros investimentos; (ii) os JSCP são tratados como receita ou despesa financeira para fins fiscais.

A nosso ver, no entanto, essa corrente não deve prosperar, uma vez que os JSCP se distinguem da remuneração própria dos investimentos realizados por meio de capital de terceiros, concedidos em virtude de contratos de empréstimo firmados nos termos analisados no item 3 do Capítulo II. Conforme visto neste trabalho, os juros decorrentes de empréstimos são o fruto $^{302}$ do capital aplicado; representam a remuneração pelo risco de reembolso e pelo tempo determinado durante o qual a quantia cedida ficou indisponível para uso do mutuante. Esses juros, portanto, pressupõem a existência de uma dívida, i.e., de um passivo exigível. Aliás, vale relembrar que o passivo exigível da sociedade serve exatamente para medir o volume de capital de terceiros aplicado ${ }^{303}$.

Nos investimentos realizados por meio de capital próprio, não se tem a criação de uma dívida. Aliás, essa premissa faz parte da própria definição de capital próprio, proposta por Bulhões Pedreira ${ }^{304}$ nos seguintes termos:

"Conforme o capital seja transferido para a sociedade empresária com ou sem o nascimento de obrigação de restituição, suas fontes são de capital de terceiros ou próprio."

É o capital de terceiros, e não o capital próprio, que, na lição de Barros Leães e Mauro Penteado, é também conhecido como capital-crédito, exatamente em virtude do nascimento de um crédito (registrado no passivo exigível da sociedade) do terceiro contra a sociedade financiada ${ }^{305}$.

\footnotetext{
301“"Portanto, por esta análise do regime jurídico-positivo da remuneração do capital próprio, e pela natureza das coisas, do custo financeiro do capital, pelos objetivos colimados pelo legislador e pelo contexto significativo da legislação aplicável, concluo ter a remuneração do capital próprio a natureza de despesa financeira para a pessoa jurídica (...)’ROLIM, João Dácio. op. cit., p. 391.

${ }^{302}$ SANTOS, J. M. de Carvalho. op. cit., p. 451. No mesmo sentido, MIRANDA, Francisco Cavalcanti Pontes de. op. cit., v. 42, p. 29. Esse mesmo doutrinador, ao se referir à origem dos juros, ensina que "são os interesses, as usuras do direito romano, donde, posteriormente, em sentido pejorativo, 'usura', 'usurário', 'usurar'”.

${ }^{303}$ Vide item 2.1. do Capítulo I deste trabalho.

${ }^{304}$ PEDREIRA, José Luiz Bulhões. op. cit., p. 386.

${ }^{305}$ PENTEADO, Mauro Rodrigues. op. cit., p. 33, e LEÃES, Luiz Gastão Paes de Barros. op. cit., p. 79.
} 
Especialmente em relação a essa última linha de pensamento, Alberto Xavier afirma que, além do tratamento tributário próprio de receitas e despesas financeiras, também a utilização do termo "juros" agrava essa recorrente discussão sobre a natureza dos $\mathrm{JSCP}^{306}$.

O termo "juros", assim como os termos "dividendos" e "JSCP", é originário do Direito Privado e, como tal, deve ser analisado. Os artigos 109 e 110 do Código Tributário Nacional - CTN (Lei $\left.\mathrm{n}^{\text {o }} 5.172 / 66\right)^{307}$ - determinam que a mutabilidade de conceitos do Direito Privado pelo Direito Tributário é permitida apenas em relação a conceitos que não estiverem previstos em lei para definir ou limitar competências tributárias. Esse entendimento é confirmado por Heleno Taveira Tôrres ${ }^{308}$, que afirma que a atuação do legislador tributário está limitada apenas pelo princípio conservativo dos tipos e formas dos atos e negócios jurídicos de Direito Privado, na hipótese de que estes se encontrem relacionados com aqueles adotados pela Constituição Federal para a distribuição de competências.

Nesse sentido, ainda que a legislação tributária estabeleça tratamento específico para os JSCP, a análise desse tratamento não é suficiente para definir sua natureza, como sugerem os autores adeptos dessa terceira linha de pensamento.

\footnotetext{
${ }^{306}$ XAVIER, Alberto. op. cit., p. 7; e BASTIANELLO, Cristina Cezar. Juros sobre o capital próprio natureza jurídica e tratamento conferido pela lei interna e pelos tratados para evitar dupla tributação internacional firmados pela República Federativa do Brasil. In: TÔRRES, Heleno Taveira (Org.). Direito tributário internacional aplicado. São Paulo: Quartier Latin, 2005. v. 3, p. 721-762.

307“Artigo 109. Os princípios gerais de direito privado utilizam-se para pesquisa da definição, do conteúdo e do alcance de seus institutos, conceitos e formas, mas não para definição dos respectivos efeitos tributários.

Artigo 110. A lei tributária não pode alterar a definição, o conteúdo e o alcance de institutos, conceitos e formas de direito privado, utilizados, expressa ou implicitamente, pela Constituição Federal, pelas Constituições dos Estados, ou pelas Leis Orgânicas do Distrito Federal ou dos Municípios, para definir ou limitar competências tributárias."

${ }^{308}$ É importante ressaltar que, conforme esse mesmo autor, esse entendimento não incorre em qualquer prevalência do Direito Privado sobre o Direito Tributário, mas tão somente indica a superioridade do Direito Constitucional sobre os demais ramos do Direito (TÔRRES, Heleno Taveira. Direito tributário e direito privado: autonomia privada, simulação, elusão tributária, cit., p. 78). Detalhes sobre a relação entre o Direito Privado e o Direito Tributário também podem ser encontrados em SAINZ DE BUJANDA, Fernando. Sistema de derecho financeiro. Madrid, 1985. v. 1, p. 5-228; COZIAN, Maurice. Propôs désobligeants sur une «tarte à la crème»: l'autonomie et le réalisme du droit fiscal. Revue Droit Fiscal, Paris, n. 13, p. 530-535, 1999. MASSANET, Juan Ramallo. Derecho fiscal frente a derecho civil: discusion em torno a La natuerleza Del derecho fiscal entre L. Trotabas y F. Gény. Revista da Faculdad de Derecho de la Universidad Complutense de Madrid, Madrid, v. 17, p. 7-102, 1973; e FREITAS, Rodrigo. Conceitos de direito tributário e de direito privado. COSTA, Alcides Jorge, (Coord.). Direito tributário atual. São Paulo: Dialética, 2004. v. 18, p. 335-358.
} 
Ainda, para a identificação da natureza desses juros na seara do Direito Privado, além da análise acima, pode ser utilizada a análise da causa ${ }^{309}$ do ato ou negócio jurídico que implica o seu pagamento.

A causa é a finalidade que as partes contratantes pretendem atingir com o negócio jurídico a ser executado. Por esse motivo, conforme ensina Antônio Junqueira de Azevedo $^{310}$, a causa do negócio jurídico é uma das circunstâncias negociais que com o objeto e a forma, constituem a existência do negócio. Nas palavras de Gilberto de Ulhôa Canto $^{311}$, a causa é, no Direito Obrigacional, a razão bastante e determinante, enfim, a razão econômico-jurídica do negócio contratado.

Nesse sentido, especialmente em relação à forma e ao tipo negocial, a causa destina-se à sua qualificação em vista de determinado negócio jurídico realizado, apontando o real tipo negocial que corresponde à finalidade pretendida pelas partes (i.e., causa do negócio jurídico), bem como a forma que deve ser obrigatoriamente observada na sua realização ${ }^{312}$.

Conforme visto profundamente no Capítulo I deste trabalho, a remuneração do investidor (seja ele sócio ou terceiro interessado) depende do tipo de financiamento adotado. Assim, caso o financiamento seja realizado por meio de capital próprio, a remuneração correspondente poderá ser realizada por meio de dividendos, ganho de capital no incremento do valor patrimonial da sociedade ou JSCP. Em relação aos investimentos realizados por meio de capital de terceiros, apenas uma forma de remuneração está prevista, qual seja, o pagamento de juros remuneratórios.

Assim, não existe a possibilidade de equiparação dos JSCP à remuneração dos empréstimos, uma vez que o negócio jurídico do qual decorre o seu pagamento não é o mesmo daquele que determina o pagamento de juros remuneratórios.

\footnotetext{
${ }^{309}$ Para o Direito Privado, a causa é elemento essencial do ato ou do negócio jurídico e serve para individualizá-lo. Uma análise detalhada do conceito de causa do Direito Privado pode ser encontrada em CANTO, Gilberto de Ulhôa. Temas de direito tributário. Rio de Janeiro: Ed. Alba, 1964. v. 1, p. 286-333; e FREITAS, Rodrigo. op. cit., p. 335-358.

${ }^{310}$ JUNQUEIRA DE AZEVEDO, Antônio. Negócio jurídico: existência, validade e eficácia. 4. ed. São Paulo: Saraiva, 2002. p. 156.

${ }^{311}$ CANTO, Gilberto de Ulhôa. Causa das obrigações tributárias. In: SANTOS, J. M. de Carvalho; DIAS, José de Aguiar (Dirs.). Repertório Enciclopédico do Direito Brasileiro. Rio de Janeiro: Borsoi, 1947-, v. 8, p. $2-25$.

${ }^{312} \mathrm{Na}$ interpretação do negócio como um todo, deve-se verificar se existe harmonização entre a causa, o tipo e a forma adotados, de modo que, atendendo os "critérios eleitos pelo ordenamento ... permitam justificar o negócio jurídico como válido e legítimo" (TÔRRES, Heleno Taveira. Direito tributário e direito privado: autonomia privada, simulação, elusão tributária, cit., p. 141).
} 


\section{A figura da "déduction pour capital à risque" no Direito Positivo da Bélgica}

Figura similar aos JSCP pode ser encontrada na Bélgica. Criada por meio de lei publicada em 30 de junho de $2005^{313}$, a denominada "déduction pour capital à risque" 314 , ou dedução para o capital de risco, assim como os JSCP, é uma forma de remuneração dos sócios em função do custo de oportunidade do capital investido.

No mesmo sentido da já mencionada Exposição de Motivos no 325/95, a Exposição de Motivos do Ministro da Fazenda da Bélgica em relação à lei de 2005, prevê expressamente que a dedução para o capital de risco visa atenuar a discriminação fiscal economicamente injustificada entre as duas formas de financiamento das empresas, i.e., o capital próprio e o capital de terceiros.

Conforme mencionado no item 1 deste Capítulo, a mesma exposição de motivos utilizou a idéia de custo de oportunidade para justificar a criação da dedução para o capital de risco. Nesse sentido, também para o Governo Belga, a dedutibilidade de juros calculados sobre contas do patrimônio líquido justifica-se pela igualdade de tratamento tributário entre capital de terceiros e capital próprio, ao menos em relação ao valor do custo de oportunidade deste último.

Tanto é verdade que, com a criação da dedução para o capital de risco, o Governo da Bélgica extinguiu a taxa de $0,5 \%$ (zero vírgula cinco por cento), até então aplicável às contribuições de capital para a sociedade, e a substituiu por uma taxa fixa no valor de EUR25,00 (vinte e cinco euros). Ainda, em 2003, a alíquota do Imposto sobre a Renda da Bélgica foi reduzida de $39 \%$ (trinta e nove por cento) para $33 \%$ (trinta e três por cento).

Em termos gerais, a dedução para o capital de risco é calculada mediante a aplicação de taxa fixa sobre o patrimônio líquido da sociedade. Essa taxa varia em função da média dos índices de remuneração aplicáveis aos títulos públicos com vencimento de 10 anos, sendo limitada a 6,5\% (seis vírgula cinco por cento). A título de curiosidade, vale mencionar que as taxas aplicáveis na Bélgica para esses fins são expressivamente reduzidas quando comparadas com a Taxa de Juros de Longo Prazo - TJLP - aplicável no Brasil para os mesmos fins. Em relação ao exercício de 2007, a taxa aplicável na Bélgica correspondia a $3,781 \%$ (três vírgula setecentos e oitenta e um por cento), enquanto para o

\footnotetext{
${ }^{313}$ Um decreto real publicado em 3 de outubro de 2005 regulamentou as disposições dessa lei.

${ }^{314}$ Também conhecido como Notional Interest Deduction.
} 
mesmo período no Brasil a taxa aplicável era $6,25 \%$ (seis vírgula vinte e cinco por cento $^{315}$.

O valor do patrimônio líquido a ser adotado para esses fins é aquele registrado ao término do exercício que antecedeu ao período de apuração, devidamente ajustado em conformidade com as disposições do artigo $6^{\circ}$ da lei de $2005^{316}$. Portanto, também nesse ponto, a Legislação Belga se equipara à Brasileira, que também adota o patrimônio líquido do exercício para o cálculo dos JSCP.

Entretanto, o regramento belga diverge do brasileiro quanto à existência de limitação temporal para a utilização da dedução para o capital de risco. Segundo esse regramento, na hipótese de inexistência ou insuficiência de lucros para a aplicação da dedução para o capital de risco, a Legislação Belga prevê expressamente que o seu valor poderá ser compensado nos exercícios seguintes, limitada a sua manutenção pelo período máximo de sete anos.

Outra relevante diferença da Legislação Belga, quando comparada com a regulamentação brasileira sobre os JSCP, é o fato de o valor da dedução para o capital de risco não ser imediatamente passível de distribuição aos sócios. Nos termos da lei de 2005, a dedução para o capital de risco deverá permanecer em conta do passivo da sociedade por três anos subseqüentes ao seu período de apuração. Na hipótese de descumprimento dessa regra, os valores distribuídos serão considerados dividendos.

Apesar dessas diferenças, conforme vimos, a dedução para o capital de risco prevista no Direito Positivo Belga é muito semelhante à figura dos JSCP existente no Brasil. Entretanto, mesmo tendo surgido quase uma década após a criação dos JSCP nos termos da Lei $n^{\circ}$ 9.249/95, a dedução para o capital de risco foi veiculada como uma grande novidade para o incentivo dos financiamentos com capital próprio.

\footnotetext{
${ }^{315}$ Fonte: site do BANCO NACIONAL DE DESENVOLVIMENTO ECONÔMICO E SOCIAL - BNDES. Disponível em: 〈http://www.bndes.gov.br/produtos/custos/juros/tjlp.asp>.

${ }^{316}$ Artigo $1^{\circ}$ do decreto real de 2005.
} 


\section{CAPÍTULO IV. A APLICAÇÃO DOS ACORDOS INTERNACIONAIS PARA EVITAR A DUPLA TRIBUTAÇÃO NO PAGAMENTO DE JUROS SOBRE O CAPITAL PRÓPRIO A RESIDENTES OU DOMICILIADOS NO EXTERIOR}

\section{Breves considerações sobre a tributação de não-residentes pelo Estado brasileiro}

O pilar fundamental da tributação de não-residentes ${ }^{317}$ é a existência de elementos de conexão ${ }^{318}$ objetivos que os vinculam ao território de determinado Estado. Esses elementos de conexão estão diretamente atrelados ao critério espacial da regra-matriz de incidência, uma vez que é este o critério que indica o local onde se observará o estado ou ação expressa no critério material ${ }^{319}$.

Em matéria de Imposto sobre a Renda, o elemento de conexão adotado para a tributação dos não-residentes traduz-se na localização da fonte dos rendimentos. Essa idéia está intimamente ligada ao princípio da territorialidade ${ }^{320}$, tendo em vista que a

\footnotetext{
${ }^{317}$ Não existe no Ordenamento Brasileiro uma definição legal da condição de não-residente, motivo pelo qual sua determinação é dada pela negativa do conceito de residente ora previsto nos artigo 12 da Lei $\mathrm{n}^{\circ}$ 9.718/98 e $3^{\circ}$ da Instrução Normativa da Secretaria da Receita Federal no 208/02. Assim, em termos gerais, para fins de tributação do Imposto sobre a Renda, são consideradas não-residentes as pessoas físicas (i) que não residirem no Brasil em caráter permanente; (ii) que se retirarem do território nacional em caráter permanente; (iii) que ingressarem no país com visto temporário, mas permanecerem por período inferior a 183 (cento e oitenta e três) dias, consecutivos ou não, contados, dentro de um intervalo de 12 (doze) meses, da data de qualquer chegada; (iii) que se ausentarem do Brasil por período superior a doze meses consecutivos.

Da mesma forma, a Legislação Brasileira não define o conceito de não-residente aplicável às pessoas jurídicas para fins fiscais. Ainda, diferentemente do que ocorre em relação às pessoas físicas, também não é definido o conceito de residente para fins fiscais aplicável às pessoas jurídicas. Para tanto, utiliza-se do conceito de Direito Privado, segundo o qual são brasileiras as pessoas jurídicas que estão organizadas de acordo com a legislação vigente, que têm no país a sede de sua administração (Artigo 60 do Decreto-Lei n ${ }^{\circ}$ 2.627/40).

${ }^{318}$ Alberto Xavier explica detalhadamente o conceito e as características dos elementos de conexão em XAVIER, Alberto. Direito tributário internacional do Brasil. 6. ed. Rio de Janeiro: Forense, 2005. p. 251-254.

${ }^{319}$ Sobre o assunto, veja CARVALHO, Paulo de Barros. Curso de direito tributário. 14. ed. São Paulo: Saraiva, 2002. p. 248-261 e CÔELHO, Sacha Calmon Navarro. Noções da fiscalidade internacional. Belo Horizonte: UFMG, 1998.

${ }^{320}$ Sobre o princípio da territorialidade, veja SACCHETTO, Claudio. La territorialidad de la imposición. In: UCKMAR, Victor; ALTAMIRANO, Alejandro; TÔRRES, Heleno Taveira (Coord.). Impuestos sobre el comercio internacional. Buenos Aires: Editorial Ábaco, 2003. p. 43-77; CASÁS, José Osvaldo. La territorialidad en los impuestos directos en Argentina. In: UCKMAR, Victor; ALTAMIRANO, Alejandro; TÔRRES, Heleno Taveira (Coord.). Impuestos sobre el comercio internacional, cit., p. 451-492; e AMATUCCI, Andrea. La territorialidad en los impuestos directos. In: UCKMAR, Victor; ALTAMIRANO, Alejandro; TÔRRES, Heleno Taveira (Coord.). Impuestos sobre el comercio internacional, cit., p. 415-422.
} 
qualificação da sujeição ativa decorre da identificação da fonte dos rendimentos dentro dos limites territoriais de determinado Estado, permitindo, dessa forma, a tributação dos rendimentos auferidos por não-residentes.

É por essa razão que Heleno Taveira Tôrres afirma que a principal característica da tributação dos não-residentes pelo Imposto sobre a Renda é sua vinculação estrita com o princípio da territorialidade no país em que auferirem rendimentos ou estiver localizada a sua fonte ${ }^{321}$.

A respeito do conceito de fonte dos rendimentos, a doutrina brasileira mostra-se homogênea quanto à necessidade e importância da delimitação e conceituação da efetiva fonte, conforme podemos depreender da lição de Heleno Taveira Tôrres ${ }^{322}$ :

"a determinação do alcance do conceito de 'fonte' mostra-se como algo muito importante e deve ser previamente estabelecida para a definição dos rendimentos tributáveis de não-residentes, particularmente no que concerne à aplicação do tratamento isolado, mediante retenção definitiva".

Atualmente, existem duas diferentes conceituações para o termo "fonte", quais sejam: fonte como local da produção do rendimento (fonte de produção) e fonte como local em que se dá o pagamento do rendimento (fonte de pagamento) ${ }^{323}$.

O primeiro consiste claramente em conceito de ordem econômica, segundo o qual é necessária a existência de vínculo entre a renda auferida e o fato que a origina. $\mathrm{O}$ segundo conceito, por sua vez, possui natureza factual, uma vez que seu elemento central é a localização física da fonte dos recursos financeiros propriamente ditos ${ }^{324}$.

\footnotetext{
${ }^{321}$ TÔRRES, Heleno Taveira. Pluritributação internacional sobre as rendas de empresas, cit., p. 133. No mesmo sentido, ensina Alberto Xavier que "no imposto de renda, o elemento de conexão fundamental é o lugar da situação da fonte dos rendimentos, pois é ele que vai permitir a repartição, dentro dos rendimentos globais de uma pessoa, física ou jurídica, entre aqueles que se submetem, ou não, à aplicação de um dado ordenamento tributário (locus fontis). Assim, entre nós, a localização da fonte no território nacional delimita o âmbito da obrigação dos não-residentes" (XAVIER, Alberto. Direito tributário internacional do Brasil, cit., p. 303).

${ }^{322}$ XAVIER, Alberto. Direito tributário internacional do Brasil, cit., p. 338.

${ }^{323}$ Id. Ibid., p. 303-306; e TÔRRES, Heleno Taveira. Pluritributação internacional sobre as rendas de empresas, cit., p. 119-125.

${ }^{324}$ SCHOUERI, Luís Eduardo. Princípios no direito tributário internacional: territorialidade, fonte e universalidade. In: FERRAZ, Roberto Catalano Botelho (Coord.). Princípios e limites da tributação. São Paulo, Quartier Latin, 2005. p. 343.
} 
Usualmente encontramos casos práticos em que a fonte de produção guarda identidade com a fonte de pagamento do respectivo rendimento, o que evita a usual problemática referente à assimilação da fonte do rendimento ${ }^{325}$. Esse é o caso dos JSCP.

Os JSCP, independentemente da sua natureza, são, inevitavelmente, um rendimento pago por uma sociedade brasileira, cuja origem está nos resultados positivos gerados por essa mesma sociedade ${ }^{326}$. Nesse caso, portanto, a sociedade brasileira é tida como a fonte de pagamento e também como a fonte de produção dos JSCP pagos a nãoresidentes. Em outras palavras, essa sociedade é o elemento de conexão que permite ao Estado Brasileiro tributar os JSCP pagos ou creditados a seus sócios residentes no exterior.

À possibilidade de tributação dos JSCP pelo Estado Brasileiro, adiciona-se a autorização de tributação desses mesmos rendimentos pelo Estado de residência do seu beneficiário. Essa competência para tributar decorre do princípio da universalidade, segundo o qual os rendimentos auferidos por residentes, independentemente da sua origem, podem ser totalmente tributados pelo Estado de residência ${ }^{327}$. Nesse caso, portanto, o elemento de conexão com o Estado é subjetivo, uma vez que decorre da residência de determinada pessoa.

Desse concurso de pretensões tributárias, pode decorrer a dupla tributação internacional, caso os Estados decidam efetivamente exercer seu poder de $\operatorname{tributar}^{328}$. Considerando que, conforme visto em detalhes no Capítulo III, o Estado Brasileiro de fato tributa os JSCP pagos a não-residentes, na hipótese de o Estado de residência não prescrever qualquer mecanismo unilateral para evitar a dupla tributação desses rendimentos $^{329}$, a solução é a utilização de acordos para evitar a sua dupla tributação. É

\footnotetext{
${ }^{325} \mathrm{O}$ estudo das fontes de rendimento como elemento de conexão pode ser denso e muito detalhado. Entretanto, esse estudo não pretende abordar esse tema com profundidade, uma vez que, no caso dos JSCP, não importarão as suas especificidades. Ana Cláudia Akie Utumi aprofunda o estudo da fonte como critério de conexão em $O$ regime tributário brasileiro do imposto sobre a renda de não-residente: a fonte como critério de conexão. 2006. Tese (Doutorado) - Faculdade de Direito, Universidade de São Paulo, São Paulo, 2006.

${ }^{326}$ Conforme analisado no Capítulo III, o pagamento ou crédito de JSCP está limitado a 50\% dos lucros do exercício ou $50 \%$ dos lucros acumulados e reservas de lucros.

${ }^{327}$ TÔRRES, Heleno Taveira. Pluritributação internacional sobre as rendas de empresas, cit., p. 86-92; HAMAEKERS, Hubert. The source principle versus the residence principle. Cadernos de Direito Tributário e Finanças Públicas, São Paulo, n. 3, p. 164-166, abr./jun. 1993; e VOGEL, Klaus. World-wide or source taxation of income? Rassegna Tributaria, Roma, v. 31, p. 259-262, 1988.

${ }^{328}$ GEST, Guy; TIXIER, Gilbert. Droit fiscal international. Paris: PUF, 1990. p. 19-28; PIRES, Manuel. Da dupla tributação jurídica internacional sobre o rendimento. Lisboa: Centro de Estudos Fiscais, 1987. p. 18-24, 78-83; e GARBARINO, Carlo. La tassazione del reddito transnazionale. Padova: CEDAM, 1990. p. 391-398.

${ }^{329}$ Sobre os mecanismos unilaterais utilizados para a atenuação ou eliminação da dupla tributação internacional, veja DORNELLES, Francisco Neves. A dupla tributação internacional da renda. Rio de Janeiro: Ed. da Fundação Getúlio Vargas, 1979. p. 11-17; BUHLER, Ottmar. Princípios de derecho internacional tributário. Trad. Fernando Cervera Torrejon.. Madrid: Estudios de Derecho Financiero, 1968. p. 223-227.
} 
essa última forma de eliminação da dupla tributação dos JSCP que este estudo passa a focar $^{330}$.

\section{Breves considerações sobre os acordos internacionais. O Modelo de Convenção relativa a Impostos sobre a Renda e o Capital proposto pela OCDE}

A relação entre o Direito Interno e o Direito Internacional é explicada por duas diferentes teorias: a teoria monista e a teoria dualista.

A principal diferença entre essas teorias pode ser resumida na aplicação ou não da idéia de unicidade da ordem jurídica: enquanto a teoria monista pressupõe a unicidade sistêmica, a teoria dualista defende a pluralidade de ordens jurídicas. Em outras palavras, a teoria monista entende que a concepção de um sistema jurídico depende da existência de uma norma fundamental que se sobrepõe às demais. Diferentemente, a teoria dualista exige que o Direito Internacional e o Direito Interno sejam duas ordens jurídicas distintas, com particulares fontes de produção e critérios de validade ${ }^{331}$.

A teoria monista divide-se em três espécies: (i) predomínio do Direito Interno sobre o Direito Internacional; (ii) predomínio do Direito Internacional sobre o Direito Interno; e (iii) equivalência dos Direitos Interno e Internacional (monismo moderado). Por essa teoria, o Direito Interno e o Direito Internacional convivem de forma unida, mesmo nas espécies em que há o predomínio de um deles. Nesse último caso, portanto, impossível falar em prevalência do Direito Internacional sobre o direito interno ${ }^{332}$.

Por sua vez, segundo a teoria dualista, as fontes e os critérios de validade inerentes ao Direito Interno estão previstos na constituição correspondente e aqueles inerentes ao Direito Internacional decorrem do princípio pacta sunt servanda, da vontade

\footnotetext{
${ }^{330}$ Uma análise detalhada sobre a dupla tributação e os métodos para a eliminação ou mitigação dos seus efeitos pode ser encontrada em CALDERÓN CARRERO, José Manuel. La doble imposición internacional y los métodos para su eliminación. Madrid: McGraw Hill, 1997. p. 54-120.

${ }^{331}$ TÔRRES, Heleno Taveira. Pluritributação internacional sobre as rendas de empresas, cit., p. 553-559; e SILVEIRA, Rodrigo Maitto da. Aplicação de tratados internacionais contra a bitributação: qualificação de partnerships joint ventures. São Paulo: Ed. Quartier Latin, 2006. p. 84-87.

${ }^{332}$ Alberto Xavier defende que o Ordenamento Brasileiro adota a teoria monista, tendo em vista que coexiste de forma coerente com o Ordenamento Internacional, ainda que dotado de vigência autônoma e plena (XAVIER, Alberto. Direito tributário internacional do Brasil, cit., 111-113).
} 
dos signatários e das normas consuetudinárias. Representam, portanto, duas ordens completamente distintas, que se unem apenas no momento em que aplicadas ${ }^{333}$.

Rodrigo Maitto da Silveira destaca a importância da definição da corrente aplicável no Direito Brasileiro para fins de interpretação dos acordos internacionais. Segundo esse autor, a principal diferença entre essas correntes na seara da interpretação desses acordos reside na possibilidade ou não de recurso às normas de interpretação vigentes no Direito Nacional ${ }^{334}$.

\subsection{A hierarquia entre as normas jurídicas internas e externas no Sistema Tributário Brasileiro}

A relação hierárquica entre os tratados e acordos internacionais e as normas jurídicas internas deve ser analisada sob duas perspectivas: posição hierárquica em relação à Constituição Federal e em relação às normas infraconstitucionais.

No primeiro caso, segundo o artigo $5^{\circ}$, parágrafos $2^{\circ}$ e $3^{\circ 335}$, da Constituição Federal, temos que somente os textos dos tratados e acordos internacionais em matéria de Direitos Humanos serão incorporados ao próprio texto constitucional, subordinando-se apenas a eventual apreciação pelo Supremo Tribunal Federal ${ }^{336}$. Nesses casos, a sua abolição é expressamente vedada, até mesmo por emenda constitucional ${ }^{337}$.

\footnotetext{
${ }^{333}$ Heleno Taveira Tôrres defende que o Brasil adota essa corrente e, para tanto, enumera artigos da Constituição Federal que, no seu entendimento, revelam a existência de fronteiras claramente delimitadas entre o Direito Interno e o Internacional (TÔRRES, Heleno Taveira. Pluritributação internacional sobre as rendas de empresas, cit., p. 569-577).

${ }^{334}$ SILVEIRA, Rodrigo Maitto da. op. cit., p. 86-87.

335“Artigo 5". Todos são iguais perante a lei, sem distinção de qualquer natureza, garantindo-se aos brasileiros e aos estrangeiros residentes no País a inviolabilidade do direito à vida, à liberdade, à igualdade, à segurança e à propriedade, nos termos seguintes:

(...)

Parágrafo $2^{\boldsymbol{a}}$. Os direitos e garantias expressos nesta Constituição não excluem outros decorrentes do regime e dos princípios por ela adotados, ou dos tratados internacionais em que a República Federativa do Brasil seja parte.

Parágrafo $3^{\circ}$. Os tratados e convenções internacionais sobre direitos humanos que forem aprovados, em cada Casa do Congresso Nacional, em dois turnos, por três quintos dos votos dos respectivos membros, serão equivalentes às emendas constitucionais. (...)"

${ }^{336}$ Artigo 102, inciso III, alínea 'b', da Constituição Federal.

“Artigo 102. Compete ao Supremo Tribunal Federal, precipuamente, a guarda da Constituição, cabendolhe:

(...)

III - julgar, mediante recurso extraordinário, as causas decididas em única ou última instância, quando a decisão recorrida:

(...)

b. declarar a inconstitucionalidade de tratado ou lei federal; (...)"

337، Artigo 60. A Constituição poderá ser emendada mediante proposta:
} 
Assim, os demais tratados e acordos internacionais, inclusive aqueles de matéria tributária, que foram devidamente recepcionados e ratificados, estarão sempre em plano inferior à Constituição Federal e sujeitos ao controle de constitucionalidade pelo Supremo Tribunal Federal ${ }^{338}$.

Quanto à relação hierárquica entre os tratados e acordos internacionais e as normas infraconstitucionais, entendemos que, nesse caso, o Direito Internacional prevalece sobre as normas de Direito Interno ${ }^{339}$. Essa posição é pacificada na jurisprudência do Supremo Tribunal Federal, o qual entende que, em matéria tributária, as normas internacionais incorporadas ao ordenamento interno se encontram em patamar hierárquico superior àquele das leis ordinárias ${ }^{340}$.

Nesse sentido, o próprio Código Tributário Nacional - Lei no 5.172/66 determina a prevalência das normas internacionais, quando, em seu artigo 98, estabelece que "os tratados e as convenções internacionais revogam ou modificam a legislação tributária interna, e serão observados pela que lhes sobrevenha".

A esse respeito, é importante mencionar que, assim como Alberto Xavier ${ }^{341}$ e Heleno Taveira Tôrres ${ }^{342}$, entendemos que o artigo 98 do Código Tributário Nacional encontra respaldo constitucional, ao instituir funções receptoras e comportamentais em relação a atos internacionais, uma vez que está constitucionalmente autorizado a estabelecer normas gerais em matéria de Legislação Tributária ${ }^{343}$.

Em outras palavras, assumindo que as funções imputadas ao artigo 98 do Código Tributário Nacional - Lei $\mathrm{n}^{\circ}$ 5.172/66 - têm natureza de norma geral tributária, a recepção dessa lei ordinária pela Constituição Federal de 1988 como lei complementar permite que

$$
\text { (...) }
$$

Parágrafo $4^{o}$. Não será objeto de deliberação a proposta de emenda tendente a abolir:

(...)

IV. os direitos e garantias individuais. (...)"

${ }^{338}$ Veja nota de rodapé $n^{\circ} 20$. TÔRRES, Heleno Taveira. Tratados e convenções internacionais em matéria tributária e o federalismo fiscal brasileiro. Revista Dialética de Direito Tributário, São Paulo, n. 86, p. 4142, nov. 2002.

${ }^{339}$ Veja artigos $4^{\circ}, 5^{\circ}$, parágrafo $2^{\circ}, 178,192$, inciso III, entre outros.

${ }^{340}$ Detalhes sobre o histórico da jurisprudência do Supremo Tribunal Federal podem ser encontrados em SILVEIRA, Rodrigo Maitto da. op. cit., p. 91-92.

${ }^{341}$ XAVIER, Alberto. Direito tributário internacional do Brasil, cit., p. 120.

${ }^{342}$ TÔRRES, Heleno Taveira. Tratados e convenções internacionais em matéria tributária e o federalismo fiscal brasileiro, cit., p. 44, 2002.

${ }^{343}$ Id. TÔRRES, Heleno Taveira. Funções das leis complementares no sistema tributário nacional - hierarquia de normas - papel do Código Tributário Nacional no ordenamento. Revista de Direito Tributário, São Paulo, n. 84, p. 55-60, 1995. 
ela estabeleça regras dessa natureza, nos termos do artigo 146, inciso III, da Constituição Federal.

\subsection{Modelos de acordos internacionais destinados a evitar a dupla tributação internacional da renda}

Os modelos de acordos internacionais em matéria tributária são considerados apenas como uma pauta a ser seguida pelos Estados em suas negociações particulares. Não imputam aos Estados qualquer forma de vinculação ao seu texto, nem mesmo em relação àqueles que são membros das organizações internacionais que propõem os modelos. Em outras palavras, os modelos de acordos destinam-se apenas a orientar os Estados contratantes na sua execução, sem qualquer obrigação de adoção do seu conteúdo integral.

Aliás, esses modelos não disciplinam completa e detalhadamente o tratamento tributário a ser dispensado às rendas transnacionais. Limitam-se a aspectos essenciais da tributação sobre as categorias dos rendimentos e dos modos de resolução de conflitos impositivos. Por esse motivo, a vinculação à sua utilização pelos Estados implicaria a insuficiência de regulamentação do acordo a ser firmado ${ }^{344}$.

Quanto aos comentários aos modelos de acordos em matéria tributária, entendemos que sua função essencial reside no auxílio à interpretação do texto do modelo proposto. Isso porque transmitem o real intuito do criador desses modelos e, portanto, asseguram que a adoção das cláusulas propostas se dê de forma equivalente. Conseqüentemente, podem ser utilizados na interpretação dos próprios acordos efetivamente firmados pelos Estados.

Atualmente, o modelo de acordo mais utilizado para evitar ou mitigar os efeitos de potencial dupla tributação de rendimentos transnacionais é aquele proposto pela OCDE, denominado Modelo de Convenção Relativa a Impostos sobre a Renda e o Capital ${ }^{345}$

\footnotetext{
${ }^{344}$ TÔRRES, Heleno Taveira. Pluritributação internacional sobre as rendas de empresas, cit., p. 503.

${ }^{345}$ A Organização das Nações Unidas - ONU, assim como os Estados Unidos da América, possuem modelos próprios de acordos para evitar a dupla tributação. Entretanto, para os fins deste trabalho, convencionou-se utilizar a Convenção Modelo da OCDE, principalmente em virtude da sua recorrente utilização como modelo, mesmo por países que não são membros dessa organização, como é o caso do Brasil.
} 
(doravante denominado Convenção Modelo da OCDE). Segundo Klaus Vogel ${ }^{346}$, a Convenção Modelo da OCDE e seus comentários representam um mecanismo de grande importância para a interpretação dos acordos internacionais, uma vez que unificam normas adotadas por uma parcela significativa dos Estados.

Essa Convenção Modelo se estrutura em diversos artigos que tratam de cada um dos rendimentos de forma individual, imputando regras específicas para evitar sua dupla tributação. Dessa necessidade de qualificação dos rendimentos podem decorrer problemas de interpretação e aplicação da Convenção Modelo da OCDE.

\subsubsection{O conflito de qualificação no âmbito da Convenção Modelo da OCDE}

No âmbito dos acordos para evitar a dupla tributação, o conflito de qualificação tem origem na sua aplicação e interpretação pelos Estados contratantes. Segundo Klaus Vogel, essa problemática decorre da utilização de termos comuns, no acordo e nas legislações internas dos Estados contratantes, para designar os rendimentos abrangidos ${ }^{347}$.

Gerd Rothmann aponta, inclusive, que a problemática em relação à qualificação dos rendimentos é uma das origens da sua dupla tributação, na medida em que o conceito do rendimento objeto da aplicação do acordo é essencial para a delimitação da competência para tributar ${ }^{348}$.

Sobre esse assunto, é importante mencionar a regra constante do parágrafo $2^{\circ}$ do artigo $3^{\mathrm{o}^{349}}$ da própria Convenção Modelo da OCDE. Segundo esse dispositivo, a possibilidade de remissão à legislação interna na interpretação das normas desse modelo de acordo tributário será possível apenas nos casos em que o rendimento não possua definição

\footnotetext{
${ }^{346}$ VOGEL, Klaus. On double taxation conventions: a commentary to the OECD, UN and US Model Conventions for the avoidance of double taxation of income and capital (with particular reference to German Treaty Practice). 3. ed. Boston: Kluwer, 1996. p. 43.

${ }^{347}$ Id. Ibid., p. 52.

${ }^{348}$ ROTHMANN, Gerd W. Problemas de qualificação na aplicação das convenções contra a bitributação internacional. Revista Dialética de Direito Tributário, São Paulo, n. 76, p. 35, jan. 2002.

349"2. As regards the application of the Convention at any time by a Contracting State, any term not defined therein shall, unless the context otherwise requires, have the meaning that it has at that time under the law of that State for the purposes of the taxes to which the Convention applies, any meaning under the applicable tax laws of that State prevailing over a meaning given to the term under other laws of that State." Heleno Taveira Tôrres analisa esse dispositivo em detalhes em TÔRRES, Heleno Taveira. Aplicação dos tratados internacionais em matéria tributária: o procedimento de interpretação. Revista da ABNT, Belo Horizonte, v. 1, p. 109-136, 1998.
} 
específica no seu texto ${ }^{350}$. Para esses fins, esse mesmo parágrafo define que a legislação interna adotada deverá ser aquela vigente no momento em que o acordo for aplicado.

Exceção a essa regra, são os casos em que o contexto de aplicação do acordo exija um procedimento diverso do reenvio à legislação interna. Para tanto, conforme Comentários da OCDE à Convenção Modelo, o termo "contexto" deve ser entendido como a intenção das partes no momento da execução do acordo, assim como o significado atribuído ao rendimento pelo outro Estado contratante ${ }^{351}$.

Esse mesmo parágrafo define também que, na eventual necessidade de reenvio à legislação interna, deverá prevalecer o significado atribuído a esse rendimento pela legislação tributária em detrimento daquele atribuído por leis de outra natureza, por exemplo, a legislação societária.

O problema que surge da aplicação da regra prevista nesse parágrafo é o fato de existirem duas legislações internas possivelmente aplicáveis, i.e., a legislação vigente no Estado da fonte e a legislação vigente no Estado da residência. Sobre esse assunto, a doutrina não é uniforme ${ }^{352}$ e propõe soluções diversas para o problema, sem a necessidade de recurso ao procedimento amigável previsto no artigo 25 da Convenção Modelo da OCDE.

Segundo ensina Heleno Taveira Tôrres, a corrente comumente adotada para a solução dessa questão é aquela na qual prevalece o reenvio à legislação interna do Estado contratante, que possui a competência prioritária para a tributação do respectivo rendimento $^{353}$. Como exemplo dessa solução adotada por esse autor, podemos citar o caso dos juros. Conforme veremos, nesse caso, a Convenção Modelo da OCDE atribui ao Estado da residência do seu beneficiário a competência prioritária para a tributação desses rendimentos. Assim, na eventual necessidade de reenvio à legislação interna dos Estados

\footnotetext{
${ }^{350}$ Diferentemente de Klaus Vogel, Alberto Xavier defende que a norma constante do parágrafo $2^{\circ}$ do artigo $3^{\circ}$ da Convenção Modelo da OCDE não se aplica ao problema da qualificação, mas apenas à interpretação dos acordos (XAVIER, Alberto. Direito tributário internacional do Brasil, cit., p. 186).

${ }^{351}$ Comentário da OCDE à Convenção Modelo reproduzido em RAAD, Kees van. Materials on international \& EC tax law. 6. ed. Leiden: International Tax Center Lieden, 2006. v. 1, p. 92. Luís Eduardo Schoueri comenta o alcance limitado do parágrafo $2^{\circ}$ do artigo $3^{\circ}$ da Convenção Modelo da OCDE em SCHOUERI, Luís Eduardo. Direito tributário internacional - qualificação e substituição - tributação, no Brasil, de rendimentos provenientes de sociedade de pessoas residente na Alemanha. Revista Dialética de Direito Tributário, São Paulo, n. 54, p. 125-139, mar. 2000.

${ }^{352}$ É importante mencionar que existe também a discussão sobre o reenvio à legislação interna ser relacionado ou não ao problema de qualificação dos rendimentos. Maiores detalhes sobre o assunto podem ser obtidos em SILVEIRA, Rodrigo Maitto da. op. cit., p. 135-138.

${ }^{353}$ TÔRRES, Heleno Taveira. Pluritributação internacional sobre as rendas de empresas, cit., p. 657. Rodrigo Maitto da Silveira detalha as características das demais correntes sobre o assunto em Aplicação de tratados internacionais contra a bitributação: qualificação de partnerships joint ventures, cit., p. 126-131.
} 
contratantes, o significado atribuído ao rendimento pelo Estado de residência deverá prevalecer sobre aquele do Estado da fonte.

A problemática quanto à qualificação dos rendimentos e a necessidade de reenvio à legislação interna dos Estados contratantes ganha destaque em relação aos JSCP. Isso porque, conforme análise constante do Capítulo III, a figura dos JSCP não é encontrada em outros ordenamentos jurídicos, com exceção da Bélgica que instituiu, em 2005, a figura da "déduction pour capital à risque" 354 . Conseqüientemente, os JSCP ou figura similar não estão expressamente qualificados na Convenção Modelo da OCDE.

Aliás, mesmo em relação aos acordos firmados pelo Brasil, são raros os casos em que os JSCP estão expressamente qualificados. Dentre os vinte e oito ${ }^{355}$ acordos firmados pelo Brasil, apenas sete prevêem especificamente a figura dos JSCP, quais sejam: os acordos firmados com a África do Sul, Bélgica, Chile, Israel, México, Portugal e Ucrânia. Isso porque, são esses os acordos que foram firmados pelo Brasil após a instituição dos JSCP no Direito Positivo Brasileiro. É importante mencionar que esses acordos determinam que, para fins de sua aplicação, os JSCP deverão ser tratados em conformidade com o artigo que cuida dos juros em geral.

Diante da diferença de tratamento tributário em função da qualificação dos JSCP no âmbito desses acordos, passamos a analisar se a posição adotada pelo Estado Brasileiro é a mais adequada.

\footnotetext{
${ }^{354}$ Ressalvada a hipótese de existirem outros ordenamentos jurídicos que possuem figura semelhante e que não foram encontrados no momento da elaboração desta dissertação.

${ }^{355}$ Nesse cálculo, foi incluído o acordo firmado com a Alemanha, o qual foi efetivamente denunciado e, portanto, não produz efeitos desde $1^{\circ}$ de janeiro de 2006. Foi também incluído o acordo firmado com Portugal, cuja validade é questionada em virtude da realização de um processo de denúncia inadequado. Para detalhes sobre a vigência do acordo firmado com Portugal, veja XAVIER, Alberto. Inexistência jurídica e inconstitucionalidade da denuncia do tratado contra a dupla tributação entre Brasil e Portugal. Revista Dialética de Direito Tributário, São Paulo, n. 48, p.7-48, set. 1999. Os demais acordos firmados pelo Brasil são: África do Sul, Argentina, Áustria, Bélgica, Canadá, Chile, China, Coréia, Dinamarca, Equador, Espanha, Filipinas, Finlândia, França, Hungria, Índia, Israel, Itália, Japão, Luxemburgo, México, Noruega, Países Baixos, Tchecoslováquia (atualmente dividida em República Eslovaca e República Tcheca), Suécia, Ucrânia.
} 


\section{A aplicação dos acordos para evitar a dupla tributação no pagamento de juros} sobre o capital próprio a investidores residentes ou domiciliados no exterior: uma análise detalhada dos artigos $7^{\circ}, 10$ e 11 da Convenção Modelo da OCDE

Conforme analisado em detalhes no Capítulo III, os JSCP são espécie de remuneração de sócios. Entretanto, em virtude das discussões que envolvem sua natureza, acreditamos que a qualificação dos JSCP no âmbito dos acordos para evitar a dupla tributação exige uma análise detalhada dos conceitos de lucros das empresas, dividendos e juros, rendimentos estes tratados na Convenção Modelo da OCDE sob os artigos $7^{\circ}, 10$ e 11.

\subsection{A qualificação dos rendimentos como lucros das empresas: a ausência de conceito na Convenção Modelo da OCDE}

Apesar de prever um artigo específico quanto à tributação dos lucros das empresas, a Convenção Modelo da OCDE não traz uma definição específica de lucro tributável e a legislação interna dos países o faz, muitas vezes com particularidades ${ }^{356}$.

A principal discussão em relação à aplicação desse artigo está atrelada aos lucros distribuídos a residentes no exterior em relação à prestação de serviços profissionais e de outras atividades de caráter independente. A nosso ver, o artigo $7^{\circ}$, apesar de intitulado genericamente como lucros das empresas, aplica-se também a esses rendimentos.

A referida conclusão decorre da exclusão do artigo 14 da Convenção Modelo da OCDE, o qual previa a regulamentação dessas atividades em termos semelhantes àqueles previstos no artigo $7^{\circ}$, exceto por utilizar o conceito de base fixa em substituição àquele de estabelecimento permanente, inicialmente utilizado apenas em relação às atividades comerciais e industriais.

Diante da nebulosidade na qualificação dos rendimentos entre os artigos $7^{\circ}$ e 14 , este último foi revogado em 2000, confirmando-se a inexistência de distinção entre os rendimentos classificáveis sob o artigo $7^{\circ}$ e aqueles classificáveis sob o artigo 14. A

\footnotetext{
${ }^{356}$ A Convenção Modelo dos EUA define o termo "lucro das empresas", mas, no entanto, não soluciona o problema de qualificação em vista da abrangência do conceito.
} 
confirmação deste tratamento veio com a inclusão dos lucros das empresas no parágrafo $1^{\circ}$ do artigo $3^{\circ}$ da Convenção Modelo da OCDE, o qual traz as definições de alguns termos utilizados da redação dessa convenção ${ }^{357}$.

A extensão do conceito de lucros das empresas aos lucros advindos da prestação de serviços demonstra que esse conceito é extremamente abrangente ${ }^{358}$, englobando uma série de rendimentos que, muitas vezes, apresentam regimes tributários específicos, instituídos por outros artigos da Convenção Modelo da OCDE, como é o caso dos juros, dividendos etc. Nesse caso, aplicar-se-ão os regimes especiais em detrimento do regime geral dos lucros das empresas previsto no artigo $7^{\mathbf{0} 359}$, conforme regra contida no parágrafo $7^{\circ}$ desse mesmo artigo ${ }^{360}$. A esse benefício de ordem, Alberto Xavier convencionou chamar de princípio da prevalência dos regimes especiais ou do caráter residual da noção de lucro de empresa ${ }^{361}$.

\subsection{A qualificação dos rendimentos como dividendos: o conceito previsto no artigo 10 da Convenção Modelo da OCDE}

A grande diversidade do conceito de dividendos nas legislações internas dos países membros da OCDE, não permitiu que o modelo de acordo proposto por essa organização previsse uma definição completa e exaustiva do conceito. Uma possível solução seria a inclusão de disposição que remetesse o intérprete à legislação interna dos Estados contratantes. Entretanto, conforme já analisado, uma disposição nesse sentido poderia gerar problemas ainda maiores de interpretação dos acordos. Por esses motivos, a OCDE decidiu que, além de formular um conceito geral, enumeraria exemplos que figuram nas legislações internas ${ }^{362}$.

\footnotetext{
357،1. For the purposes of this Convention, unless the context otherwise requires:

(...)

h) the term "business" includes the performance of professional services and of other activities of an independent character."

${ }^{358}$ ROTHMANN, Gerd W. op. cit., p. 39-40.

${ }^{359}$ Vale notar que, em alguns casos, os artigos aplicáveis a rendimentos específicos prevêem a aplicação do artigo $7^{\circ}$, como é o caso do parágrafo $4^{\circ}$ dos artigos 10 e 11 , do parágrafo $3^{\circ}$ do artigo 12 e do parágrafo $2^{\circ}$ do artigo 21.

360“7. Where profits include items of income which are dealt with separately in other Articles of this Convention, then the provisions of those Articles shall not be affected by the provisions of this Article."

${ }^{361}$ XAVIER, Alberto. Direito tributário internacional do Brasil, cit., p. 675. No mesmo sentido, TÔRRES, Heleno Taveira. Pluritributação internacional sobre as rendas de empresas, cit., p. 516.

${ }^{362}$ Comentário da OCDE à Convenção Modelo reproduzido em RAAD, Kees van. op. cit., v. 1, p. 178.
} 
Nesse sentido, o artigo 10 da Convenção Modelo da OCDE, em seu parágrafo $3^{\circ}$, estabelece o conceito de "dividendos" como "os rendimentos provenientes de ações, ações ou direitos de fruição, ações de empresas mineradoras, partes de fundadores ou outros direitos, com exceção dos créditos, que permitam participar dos lucros, assim como os rendimentos derivados de outras partes sociais sujeitas ao mesmo regime fiscal que os rendimentos de ações pela legislação do Estado de que é residente a sociedade que os distribui ${ }^{, 363}$.

Essa definição de dividendos se refere principalmente aos rendimentos provenientes de distribuições efetuadas pelas sociedades ${ }^{364}$, as quais são definidas no parágrafo $1^{\mathrm{o}}$, alínea 'b', do artigo $3^{\mathrm{o} 365}$ da Convenção Modelo da OCDE, como qualquer pessoa jurídica ou qualquer entidade considerada pessoa jurídica para fins fiscais. Assim, como elemento primeiro desse conceito, tem-se o pagamento de dividendos atrelado às participações societárias.

Aliás, esse conceito se identifica com aquele previsto na Legislação Interna Brasileira, mais especificamente na Lei das Sociedades Anônimas - Lei n 6.404/76, o qual foi detalhadamente analisado no Capítulo I. Entretanto, como se pode depreender dos exemplos listados no texto desse parágrafo $3^{\circ}$, o conceito de dividendo previsto no artigo 10 da Convenção Modelo da OCDE é mais abrangente do que aquele previsto na Legislação Interna Brasileira. Isso porque, em conformidade com a sua redação, alguns valores mobiliários são equiparados às participações societárias por concedem, ao seu titular, o direito de participar dos resultados sociais ${ }^{366}$.

\footnotetext{
${ }^{363}$ Tradução livre do parágrafo $3^{\circ}$ do artigo da Convenção Modelo. "3. The term "dividends" as used in this Article means income from shares, "jouissance" shares or "jouissance" rights, mining shares, founders' shares or other rights, not being debt-claims, participating in profits, as well as income from other corporate rights which is subjected to the same taxation treatment as income from shares by the laws of the State of which the company making the distribution is a resident." As convenções modelo propostas pela Organização das Nações Unidas - ONU - e pelos Estados Unidos da América não possuem mudanças significativas em relação à redação do parágrafo $3^{\circ}$ do artigo 10 , proposto pela OCDE. Vale mencionar, apenas, que a convenção modelo proposta pelos Estados Unidos da América não possui lista exemplificativa de rendimentos tidos como dividendos.

${ }^{364}$ Para esses fins, não importa a diferença de conceitos existente no Direito Positivo Brasileiro em relação a ações e quotas ou distribuição de lucros e dividendos. Comentário da OCDE à Convenção Modelo reproduzido em RAAD, Kees van. op. cit., v. 1, p. 179.

365"1. For the purposes of this Convention, unless the context otherwise requires:

(...)

b) the term "company" means any body corporate or any entity that is treated as a body corporate for tax purposes; (...)"

${ }^{366}$ Comentário da OCDE à Convenção Modelo reproduzido em RAAD, Kees van. op. cit., v. 1, p. 178.
} 
Portanto, à definição de dividendos nos termos da Convenção Modelo da OCDE importa que os rendimentos distribuídos aos detentores de participações de capital estejam diretamente atrelados aos resultados da sociedade.

Heleno Taveira Tôrres confirma esse entendimento ao concluir que, para os fins da Convenção Modelo da OCDE "o elemento nuclear em torno do conceito convencional de dividendos é, pois, o de rendimento de uma participação de capital, entendida como participação em uma sociedade de capitais" ${ }^{\text {367. }}$.

Além da necessidade de vinculação com os resultados da sociedade, novo elemento é trazido ao conceito de dividendos pelo parágrafo $3^{\circ}$ do artigo 10 . Esse dispositivo expressamente exclui, desse conceito, os créditos existentes contra a sociedade, mesmo quando sua remuneração está diretamente ligada aos seus resultados.

São também excluídos desse conceito os juros de obrigações passíveis de conversão em investimento direto na sociedade devedora ${ }^{368}$. Nesses casos, aplicam-se as disposições relativas ao artigo 11 da Convenção Modelo da OCDE, as quais serão analisadas a seguir, uma vez que tais rendimentos são qualificados como juros.

Vale mencionar que exceção a essa regra são os empréstimos, nos quais o mutuante participa, com os sócios, dos riscos incorridos pela sociedade mutuária no desempenho das atividades propostas. É importante destacar que essa exceção não impacta a aplicação de regras de subcapitalização previstas na legislação interna dos Estados contratantes, as quais, segundo vimos, prescrevem a desqualificação dos juros e o seu conseqüente tratamento fiscal como dividendos ${ }^{369}$.

Os comentários da OCDE à Convenção Modelo listam critérios que podem ser utilizados para a identificação dos empréstimos, que constituem, na realidade, verdadeiras participações diretas na sociedade. São eles ${ }^{370}$ :

(i) o empréstimo ultrapassa largamente todas as demais contribuições para o capital da sociedade (ou foi concedido para substituir uma parte importante do capital perdido) e o seu montante não é equiparável ao dos ativos amortizáveis;

(ii) o credor participa dos lucros da sociedade;

\footnotetext{
${ }^{367}$ TÔRRES, Heleno Taveira. Pluritributação internacional sobre as rendas de empresas, cit., p. 520. No mesmo sentido, XAVIER, Alberto. Direito tributário internacional do Brasil, cit., p. 725.

${ }^{368}$ Comentário da OCDE à Convenção Modelo reproduzido em RAAD, Kees van. op. cit., v. 1, p. 179.

${ }^{369}$ Comentário da OCDE à Convenção Modelo reproduzido em Id. Ibid., p. 179.

${ }^{370}$ Comentário da OCDE à Convenção Modelo reproduzido em Id., loc. cit.
} 
(iii) o reembolso do empréstimo está subordinado ao reembolso das dívidas com outros credores ou ao pagamento de dividendos;

(iv) o valor ou o pagamento dos juros depende dos lucros da sociedade;

(v) o contrato de mútuo não prevê o reembolso num prazo determinado.

Como podemos perceber, esses critérios são, em sua maioria, muito semelhantes àqueles mencionados no Capítulo II, em relação à definição do estado de subcapitalização nominal. Está claro, portanto, que a Convenção Modelo da OCDE também busca evitar a prática abusiva de empréstimos por sócios. Assim, mesmo na hipótese de a legislação interna dos Estados contratantes não prever qualquer disposição em relação às normas de subcapitalização nominal, como é o caso do Brasil, poderia haver a possibilidade de conversão dos juros em dividendos para fins de aplicação das normas desse modelo de acordo.

Ainda, são equiparáveis a dividendos, para fins de aplicação dos acordos, quaisquer outros benefícios cujo tratamento tributário dispensado pelo Estado de residência da sociedade pagadora é idêntico àquele dispensado aos dividendos nesse mesmo Estado. Para tanto, não é necessário que esses benefícios tenham origem nos lucros da sociedade, seja do exercício ou das contas de lucros acumulados e reservas.

Regra geral, os benefícios enquadráveis nessa hipótese são concedidos a sócios. Entretanto, são apontados dois casos nos comentários da OCDE à Convenção Modelo, nos quais esses benefícios são concedidos a terceiros e, mesmo assim, devem ser tratados como dividendos.

O primeiro caso abrange os benefícios pagos em virtude de participações denominadas ocultas, as quais podem ser entendidas como relações existentes entre os terceiros e a sociedade e que se assemelham a uma participação social. $\mathrm{O}$ segundo caso engloba os benefícios pagos a terceiros que possuem relação direta com um ou mais sócios da sociedade pagadora. Essa relação direta pode ser tanto familiar como decorrente da estrutura de um grupo societário ${ }^{371}$.

Por fim, vale mencionar que a Bélgica, no âmbito da OCDE, reservou-se o direito de incluir na definição de dividendos, para os fins do artigo 10, os pagamentos efetuados a sócios, ainda que sob a forma de juros, cujo tratamento fiscal seja idêntico àquele

\footnotetext{
${ }^{371}$ Comentário da OCDE à Convenção Modelo reproduzido em RAAD, Kees van. op. cit., v. 1, p. 180.
} 
dispensado aos rendimentos de participações societárias listadas no texto do artigo. Apesar de essa decisão ter sido tomada anteriormente à criação da figura da "déduction pour capital à risque", a inclusão desse tipo de juros na definição de dividendos pode ser vista como a justificativa necessária para imputar tratamento de dividendos à "déduction pour capital à risque".

\subsubsection{Os juros sobre o capital próprio e a sua relação com o conceito de dividendos previsto no artigo 10 da Convenção Modelo da OCDE}

Do exposto no item 3.2. acima, é possível concluir que, para a qualificação dos JSCP como dividendos no âmbito do artigo 10 da Convenção Modelo da OCDE, é necessária a identificação de duas principais características: (i) vinculação do pagamento do rendimento às participações societárias e aos resultados da sociedade pagadora; (ii) desvinculação dos rendimentos em relação a créditos existentes contra a sociedade.

Esses mesmos requisitos podem ser exigidos em relação aos acordos firmados pelo Brasil, tendo em vista que, ressalvadas algumas especificidades ${ }^{372}$, a definição de dividendos adotada é a mesma sugerida no parágrafo $3^{\circ}$ do artigo 10 da Convenção Modelo da OCDE.

Em relação aos JSCP, acreditamos que essas características em nada prejudicam sua qualificação como dividendos. Além de o seu pagamento ou crédito estar atrelado à existência de lucros do exercício ou lucros acumulados, o seu valor é definido também em função do quadro societário da sociedade. Ademais, conforme já analisado, os JSCP não advêm de créditos propriamente ditos, mas de um investimento direto realizado por meio de capital próprio.

Ainda, é importante lembrar que os rendimentos expressamente mencionados no texto do parágrafo $3^{\circ}$ do artigo 10 buscam apenas exemplificar o conceito de dividendos, conforme Comentários da OCDE à Convenção Modelo ${ }^{373}$. Não é, portanto, lista taxativa que excluiria os JSCP do âmbito de aplicação desse artigo.

\footnotetext{
${ }^{372} \mathrm{O}$ acordo firmado com a Bélgica inclui, no conceito de dividendos, os juros pagos a sócios, cujo tratamento fiscal seja idêntico àquele dispensado aos rendimentos de participações societárias. $\mathrm{O}$ acordo firmado com Portugal também amplia o conceito de dividendos para incluir os rendimentos derivados de conta ou de associação em participação.

${ }^{373}$ Comentário da OCDE à Convenção Modelo reproduzido em RAAD, Kees van. op. cit., v. 1, p. 178.
} 
Da mesma forma, a nosso ver, a possível qualificação dos JSCP como dividendos decorre do mero cumprimento das características previstas no parágrafo $3^{\circ}$ do artigo $10 \mathrm{e}$, portanto, não entram na categoria dos rendimentos equiparáveis a dividendos. Aliás, nesse último caso, exige-se que os rendimentos tenham o mesmo tratamento tributário dispensado aos dividendos pelo Estado da fonte, o que, conforme já analisado, não é o caso dos JSCP.

Além disso, segundo afirma Klaus $\operatorname{Vogel}^{374}$, o parágrafo $3^{\circ}$ do artigo 10 da Convenção Modelo da OCDE, diferentemente do seu artigo $3^{\circ}$, parágrafo $2^{\circ}$, remete a definição de dividendos à legislação interna do Estado da fonte, a qual, segundo concluímos no Capítulo III, define os JSCP como rendimentos de participações societárias.

Nesse mesmo sentido, afirma Alberto Xavier ${ }^{375}$, que os JSCP devem ser tratados como dividendos para fins de aplicação dos acordos para evitar a dupla tributação.

A conclusão definitiva em relação à qualificação dos JSCP no âmbito da Convenção Modelo da OCDE depende, ainda, da análise do artigo 11 dessa Convenção Modelo.

\subsection{A qualificação dos rendimentos como juros: o conceito previsto no artigo 11 da Convenção Modelo da OCDE}

O artigo 11 da Convenção Modelo da OCDE, em seu parágrafo $3^{0^{376}}$, define o termo "juros", para os fins dessa convenção, como os "rendimentos de créditos de qualquer natureza, garantidos ou não por hipoteca e possuindo ou não cláusulas de participação nos lucros do devedor e, em particular, os rendimentos derivados de

\footnotetext{
${ }^{374}$ OGEL, Klaus. On double taxation conventions: a commentary to the OECD, UN and US Model Conventions for the avoidance of double taxation of income and capital (with particular reference to German Treaty Practice), cit., p. 649.

${ }^{375}$ XAVIER, Alberto. Natureza jurídico-tributária dos “juros sobre o capital próprio" face à lei interna e aos tratados internacionais, cit., p. 10-11.

376، 3. The term 'interest' as used in this Article means income from debt-claims of every kind, whether or not secured by mortgage and whether or not carrying a right to participate in the debtor's profits, and in particular, income from government securities and income from bonds or debentures, including premiums and prizes attaching to such securities, bonds or debentures. Penalty charges for late payment shall not be regarded as interest for the purpose of this Article." É importante mencionar que os modelos de convenção propostos pela Organização das Nações Unidas - ONU - e pelos Estados Unidos da América são possuem alterações significativas em relação a esse parágrafo terceiro do artigo 11 da Convenção Modelo da OCDE.
} 
debêntures ou títulos da dívida pública, incluindo prêmios e bônus derivados destes títulos, ${ }^{377}$.

Segundo os comentários da OCDE ao artigo 11 da Convenção Modelo ${ }^{378}$, o termo “juros" refere-se aos rendimentos em geral recebidos como remuneração por empréstimos de qualquer natureza. São rendimentos derivados da noção de "capital móvel”379. Aliás, esses comentários expressamente diferenciam os juros dos dividendos, justificando que aqueles, diferentemente destes últimos, não estão sujeitos a uma dupla tributação econômica nas mãos do credor e do devedor ${ }^{380}$. Conforme comentaremos oportunamente, a nosso ver, essa delimitação do conceito de juros é um excelente argumento para excluir os JSCP do âmbito de aplicação desse artigo 11.

A parte final desse mesmo parágrafo expressamente exclui do conceito de juros, para os fins da Convenção Modelo, as penalidades por pagamentos em atraso ${ }^{381}$. Ou seja, se da primeira parte desse parágrafo $3^{\circ}$ se conclui que os juros são os rendimentos de créditos de qualquer natureza, pode-se chegar à conclusão de que apenas os juros remuneratórios devem ser incluídos no artigo 11 da Convenção Modelo, estando os juros de mora expressamente excluídos do tratamento tributário previsto nesse artigo.

Pontes de Miranda claramente diferencia os juros remuneratórios dos moratórios. Os primeiros "são contraprestação, correspectivo do uso e fruição do capital que se emprestou". Sua qualificação exige, portanto, a existência de um crédito ao qual está diretamente relacionado. Por sua vez, os juros de mora "supõem o não cumprimento da obrigação, a mora eficaz, ${ }^{382}$.

Assim, de forma geral, os juros enquadrados no artigo 11 da Convenção Modelo são o produto ou o fruto $^{383}$ do capital aplicado, representando a remuneração pelo risco de reembolso e pelo tempo durante o qual a quantia cedida ficou indisponível para uso do devedor. Nesse sentido, Klaus Vogel, ao comentar o âmbito de aplicação do artigo 11 da Convenção Modelo da OCDE, afirma que o termo "juros” pode ser determinado como o

\footnotetext{
${ }^{377}$ Tradução livre da primeira parte do parágrafo $3^{\circ}$ do artigo 11 da Convenção Modelo da OCDE.

${ }^{378}$ Comentário da OCDE à Convenção Modelo reproduzido em RAAD, Kees van. op. cit., v. 1, p. 203.

${ }^{379}$ Tradução livre do termo "income from movable capital".

${ }^{380}$ Comentário da OCDE à Convenção Modelo reproduzido em RAAD, Kees van. op. cit., v. 1, p. 195.

${ }^{381}$ Tradução livre da segunda parte do parágrafo $3^{\circ}$ do artigo 11 da Convenção Modelo da OCDE.

${ }^{382}$ MIRANDA, Francisco Cavalcanti Pontes de. op. cit., v. 42, p. 61.

${ }^{383}$ SANTOS, J. M. de Carvalho. op. cit., p. 451. No mesmo sentido, MIRANDA, Francisco Cavalcanti Pontes de. op. cit., v. 42, p. 29. Esse mesmo doutrinador, ao se referir à origem dos juros, ensina que "são os interesses, as usuras do direito romano, donde, posteriormente, em sentido pejorativo, 'usura', 'usurário', 'usurar'”.
} 
benefício recebido em virtude da transferência do uso do capital ${ }^{384}$. No mesmo sentido, Heleno Taveira Tôrres afirma que o aspecto central desse conceito de juros é representado pelos créditos de qualquer tipo, que compreendem todos os modos de juros ${ }^{385}$.

São, portanto, em sua essência, os juros analisados em detalhe no item 3 do Capítulo II deste trabalho, dentre eles aqueles decorrentes do financiamento de sociedades por meio de mútuo efetuado com capital de terceiros.

Ainda em relação ao conceito de juros, os comentários da OCDE ao artigo 11 da Convenção Modelo expressamente afirmam que, na qualificação dos rendimentos no âmbito dessa convenção, a substância da operação à qual os juros estão atrelados deve necessariamente prevalecer sobre sua forma ${ }^{386}$. Assim, em relação aos empréstimos concedidos à sociedade pelos seus sócios, será importante definir a real natureza dessa transferência de recursos, conforme analisado em relação à caracterização da subcapitalização nominal no item 3.2. do Capítulo II deste trabalho.

Para tanto, os comentários da OCDE complementam que os juros de títulos de dívidas devem ser considerados dividendos nas hipóteses em que o empréstimo efetivamente dividir o risco da empresa com o credor $^{387}$. Aliás, sobre o estado de subcapitalização das empresas, os comentários da OCDE reforçam a dificuldade de se identificarem os rendimentos que são realmente juros decorrentes de empréstimos. Por esse motivo, convencionou-se que os rendimentos classificáveis sob o artigo 11 da Convenção Modelo não incluem aqueles classificáveis sob o artigo 10, acima analisado em relação aos dividendos.

Sobre a definição de juros, entende-se que ela é exaustiva, de forma a evitar o reenvio à legislação interna ${ }^{388}$ para sua aplicação. Esse procedimento é justificado, nos

\footnotetext{
384"It could be simplified by saying that the term 'interest' and thus the scope of Art. 11 is determined by the benefit received where the amount to be taxed represents the payment for a transfer of the use of capital" OGEL, Klaus. On double taxation conventions: a commentary to the OECD, UN and US Model Conventions for the avoidance of double taxation of income and capital (with particular reference to German Treaty Practice), cit., p. 713.

${ }^{385}$ TÔRRES, Heleno Taveira. Pluritributação internacional sobre as rendas de empresas, cit., p. 522. No mesmo sentido, XAVIER, Alberto. Direito tributário internacional do Brasil, cit., p. 751.

386“. (...) a loan is considered to exist under a 'substance over form' rule, an 'abuse of rights' principle, or any similar doctrine" Comentário da OCDE à Convenção Modelo reproduzido em RAAD, Kees van. op. cit., v. 1, p. 204.

${ }^{387}$ Tradução livre do seguinte texto: “(...) the interest on such bonds should be considered as a dividend if the loan effectively shares the risks run by the debtor company”. Comentário da OCDE à Convenção Modelo reproduzido em RAAD, Kees van. op. cit., v. 1, p. 203.

${ }^{388}$ Pode-se depreender dos Comentários da OCDE à Convenção Modelo que se busca evitar, sempre que possível, a remissão às normas internas dos Estados contratantes, como forma de evitar conflitos, por exemplo, aqueles decorrentes de qualificação de rendimentos.
} 
termos dos Comentários da OCDE à Convenção Modelo, pelo simples fato de a definição do parágrafo $3^{\circ}$ (i) já compreender a grande maioria dos tipos de rendimentos considerados juros pelas legislações internas dos Estados; (ii) ser uma fórmula que concede segurança jurídica aos residentes dos Estados contratantes.

Por fim, vale mencionar que a Bélgica, no âmbito da OCDE, seguindo o exemplo adotado em relação aos dividendos, reservou-se o direito de expressamente excluir, da definição de juros, aqueles pagos a sócios e cujo tratamento fiscal seja idêntico àquele dispensado aos rendimentos de participações societárias nos termos da legislação interna desse país.

\subsubsection{Os juros sobre o capital próprio e a sua relação com o conceito de juros previsto no artigo 11 da Convenção Modelo da OCDE. As diferenças do conceito de juros adotado nos acordos firmados pelo Brasil}

Da definição de juros analisada acima, conclui-se que o seu elemento central é a existência de relação direta com um crédito com a sociedade. Segundo os próprios Comentários da OCDE ao artigo 11 da Convenção Modelo, o termo juros refere-se aos rendimentos em geral recebidos como remuneração por empréstimos de qualquer natureza.

Os rendimentos abrangidos pelo artigo 11 da Convenção Modelo não compreendem, portanto, os JSCP que, conforme analisamos, não decorrem de crédito dos sócios com a sociedade, mas de investimento efetuado mediante capital próprio. Assim, pode-se depreender que os juros qualificáveis no artigo 11 dessa convenção são, em sua essência, os juros como aqueles decorrentes do financiamento de sociedades por meio de mútuo efetuado com capital de terceiros.

Apesar de os acordos firmados pelo Brasil seguirem a redação proposta pela Convenção Modelo da OCDE, foi adicionada, à sua maioria, frase que poderia implicar a qualificação dos JSCP como “juros”.

Exceto pelos acordos firmados pelo Brasil com a China, a Finlândia e a Ucrânia, todos os demais acordos vigentes qualificam como "juros" os rendimentos que, de acordo 
com a legislação tributária do Estado de que provenham, sejam assemelhados aos rendimentos de importâncias emprestadas ${ }^{389}$.

Especialmente em relação ao acordo firmado com o Canadá, vale mencionar que, apesar de qualificar como "juros" os rendimentos assemelhados àqueles de importâncias emprestadas, esse acordo expressamente afirma que o termo "juros" não abrange os rendimentos tratados como dividendos, tais como os rendimentos de créditos que correspondam a uma participação nos lucros do devedor.

No caso dos JSCP, se analisarmos apenas os termos da legislação tributária que os governam, poder-se-ia afirmar que são um rendimento assemelhado aos rendimentos de importâncias emprestadas. Isso porque, ainda que definidos como uma forma de remuneração de sócios, essa conclusão não decorre de análise exclusiva das normas da seara tributária. Tanto é assim, que, conforme visto, parte dos autores afirma que os JSCP são juros propriamente ditos e, para tanto, baseiam-se no tratamento tributário que lhes é dispensado.

A nosso ver, no entanto, a inclusão do reenvio à Legislação Interna Brasileira na definição de "juros" não deve prosperar sobre a própria definição de dividendos, prevista nos acordos firmados pelo Brasil, nos mesmos termos da Convenção Modelo da OCDE.

Segundo Klaus Vogel, o reenvio à legislação interna é um mecanismo que permite uma adequada compreensão do rendimento. Entretanto, esse mesmo autor aponta que o reenvio à legislação interna do país da fonte acarreta a possível adoção de entendimentos divergentes entre os Estados contratantes, o que, conforme visto, poderia implicar a dupla tributação dos rendimentos, ou mesmo a inexistência de qualquer tributação ${ }^{390}$.

Nesse sentido, de forma a assegurar o objetivo dos acordos para evitar a dupla tributação, tem-se que o reenvio à legislação interna deve ser evitado sempre que possível e sua aplicação deve ser vista como recurso subsidiário àqueles fornecidos pelo próprio acordo. Aliás, esse é o entendimento constante dos próprios comentários da OCDE à Convenção Modelo ${ }^{391}$.

\footnotetext{
${ }^{389}$ No mesmo sentido, veja OKUMA, Alessandra de Souza. Princípio da não-discriminação internacional no direito brasileiro. 2005. Dissertação (Mestrado) - Pontifícia Universidade Católica - PUC/SP, São Paulo, 2005. p. 261-262.

${ }^{390}$ XAVIER, Alberto. Direito tributário internacional do Brasil, cit., p. 199-201.

${ }^{391}$ Comentário da OCDE à Convenção Modelo reproduzido em RAAD, Kees van. op. cit., v. 1, P. 178.
} 
No mesmo sentido, Gerd Rothmann afirma que, apesar de acreditar que o reenvio à legislação interna deve ser sempre utilizado na qualificação dos rendimentos, muitas vezes, para a correta aplicação do acordo, é necessária a interpretação das próprias normas internacionais $^{392}$.

Na nossa opinião, esse é o caso dos JSCP. No âmbito dos acordos firmados pelo Brasil, a definição adotada para o conceito de dividendos é suficiente para a qualificação dos JSCP da mesma forma. Assim, a despeito de a grande maioria dos acordos firmados pelo Brasil prever o reenvio à legislação interna na definição de juros, acreditamos que essa previsão não deve ter qualquer impacto na adequada qualificação dos JSCP como dividendos. Ainda, pelos mesmos motivos, é indevida a qualificação expressa dos JSCP como "juros", incluída nos acordos firmados pelo Brasil com a África do Sul, Bélgica, Chile, Israel, México, Portugal e Ucrânia.

Esse entendimento é confirmado por Alberto Xavier:

"É nossa opinião que a subsunção direta dos 'juros sobre o capital próprio' no conceito de dividendo, assim considerado o rendimento de participações societárias, sobrepõe-se às disposições convencionais que procedem a uma remissão subsidiária para a 'lex fori' (...)”393.

É importante ressaltar que existem autores, por exemplo, Alessandra de Souza Okuma, que divergem do nosso entendimento e acreditam que os JSCP devem ser qualificados como "juros", exceto nos acordos firmados com o Canadá, China, Finlândia e Ucrânia, nos quais os JSCP devem ser qualificados como dividendos 394 .

\section{4. $\mathrm{O}$ tratamento tributário dispensado aos rendimentos no âmbito dos artigos $10 \mathrm{e}$ 11 da Convenção Modelo da OCDE}

Exceto por algumas particularidades, o Brasil adotou a redação proposta pela OCDE para os artigos que governam a tributação dos juros e dos dividendos. Assim, tendo em vista que o presente estudo não se destina a analisar cada um dos acordos firmados pelo

\footnotetext{
${ }^{392}$ ROTHMANN, Gerd W. Interpretação e aplicação dos acordos internacionais contra a bitributação. 1978. Tese (Doutorado) - Faculdade de Direito, Universidade de São Paulo, São Paulo, 1978. p. 59-60.

${ }^{393}$ XAVIER, Alberto. Natureza jurídico-tributária dos “juros sobre o capital próprio" face à lei interna e aos tratados internacionais, cit., p. 7-11.

${ }^{394}$ OKUMA, Alessandra de Souza. op. cit.
} 
Brasil, limitar-nos-emos a comentar as regras aplicáveis a esses dois artigos no âmbito da Convenção Modelo da OCDE, como forma de demonstrar as diferenças de tratamento tributário decorrente da imprecisão do processo de qualificação dos JSCP, adotado pelo Governo brasileiro.

\subsubsection{A atribuição de competência aos Estados contratantes em relação à tributação dos dividendos enquadrados no Artigo 10 da Convenção Modelo da OCDE}

O parágrafo $1^{\text {o395 }}$ do artigo 10 da Convenção Modelo da OCDE define a regra geral de atribuição de competência entre os Estados para a tributação dos dividendos. Segundo esse parágrafo, os dividendos provenientes de um Estado contratante e pagos a um residente do outro Estado contratante poderão ser tributados nesse outro Estado.

A redação desse artigo nos permite afirmar que a competência, nesse caso, é concorrente. Isso porque, ao utilizar a expressão "poderão ser tributados nesse outro Estado" 396 , definiu-se que o Estado de residência está autorizado a tributar os juros pagos, afastando qualquer competência exclusiva do Estado da fonte para a tributação desses rendimentos ${ }^{397}$. Além disso, a primeira parte do parágrafo $2^{\circ}$ desse mesmo artigo 10 confirma a competência do Estado da fonte para tributar esses rendimentos ${ }^{398}$.

A adoção da competência concorrente dos Estados da fonte e da residência justifica-se por dois motivos: (i) a atribuição de competência exclusiva do Estado da fonte poderia incorrer no fenômeno da dupla não-tributação, uma vez que parte dos Estados não tributa na fonte esses rendimentos, enquanto uma parcela significativa desses mesmos Estados tributa os dividendos no nível do beneficiário; (ii) a atribuição de competência exclusiva ao Estado de residência do beneficiário pressupõe a irreal possibilidade de renúncia completa de tributação pelo Estado da fonte.

\footnotetext{
395“1. Dividends paid by a company which is a resident of a Contracting State to a resident of the other Contracting State may be taxed in that other State." A redação da Convenção Modelo proposta pela Organização das Nações Unidas é idêntica àquela proposta pela OCDE. Entretanto, a Convenção Modelo proposta pelos Estados Unidos da América prevê a competência exclusiva do Estado de residência para a tributação dos juros."

${ }^{396}$ Tradução livre do extrato de texto "may be taxed".

${ }^{397}$ Comentário da OCDE à Convenção Modelo reproduzido em RAAD, Kees van. op. cit., v. 1, p. 174.

398“2. However, such dividends may also be taxed in the Contracting State of which the company paying the dividends is a resident and according to the laws of that State (...)"
} 
Assim como será visto em relação aos juros, a expressão "pagos", utilizada no parágrafo $1^{\circ}$ do artigo 10, possui, no âmbito da Convenção Modelo, sentido suficientemente amplo para abranger todas as situações que impliquem a disponibilização dos rendimentos aos seus beneficiários. Para tanto, os dividendos consideram-se pagos quando postos à disposição dos beneficiários em conformidade com a prática usual ou com os termos do estatuto ou contrato social respectivo ${ }^{399}$.

Os demais parágrafos desse artigo 10 , i.e., parágrafos $2^{\circ}, 4^{\circ}$ e $5^{\circ}$, definem limites e exceções à regra de competência concorrente dos Estados da fonte e da residência por meio da definição de alíquotas máximas e imposição de critérios específicos em função da existência de estabelecimentos permanentes.

O primeiro limite imposto à regra geral está previsto no parágrafo $2^{\mathrm{o}^{400}}$, que limita a tributação pelo Estado da fonte. Esse Estado, apesar de autorizado a tributar os dividendos em conformidade com a sua legislação interna, deverá limitar referida tributação às seguintes alíquotas:

(i) $5 \%$ (cinco por cento) do montante bruto dos dividendos nos casos em que o seu beneficiário efetivo é uma sociedade (com exceção de uma sociedade de pessoas) que detenha, diretamente, pelo menos $25 \%$ (vinte e cinco por cento) do capital da sociedade que paga os dividendos;

(ii) $15 \%$ (quinze por cento) do montante bruto dos dividendos, nos demais casos.

A limitação da tributação dos dividendos pelo Estado da fonte não impacta a tributação dos lucros no nível das sociedades e requer que o beneficiário efetivo desses rendimentos seja residente no outro Estado contratante. Essa é uma medida adotada para evitar a utilização abusiva dos acordos por meio da interposição de pessoas residentes nos Estados contratantes. Em outras palavras, busca-se evitar as situações em que o real

\footnotetext{
${ }^{399}$ Comentário da OCDE à Convenção Modelo reproduzido em RAAD, Kees van. op. cit., v. 1, p. 174.

${ }^{400}{ }_{6} 2$. However, such dividends may also be taxed in the Contracting State of which the company paying the dividends is a resident and according to the laws of that State, but if the beneficial owner of the dividends is a resident of the other Contracting State, the tax so charged shall not exceed:

a) 5 per cent of the gross amount of the dividends if the beneficial owner is a company (other than a partnership) which holds directly at least 25 per cent of the capital of the company paying the dividends;

b) 15 per cent of the gross amount of the dividends in all other cases.

The competent authorities of the Contracting States shall by mutual agreement settle the mode of application of these limitations.

This paragraph shall not affect the taxation of the company in respect of the profits out of which the dividends are paid." Apesar de a Convenção Modelo proposta pela Organização das Nações Unidas ser muito semelhante àquele modelo proposto pela OCDE, ela determina que o limite máximo para a tributação pelo Estado da fonte deve ser determinado pelos Estados contratantes.
} 
beneficiário dos dividendos, sendo residente em país que não possui acordo firmado com o Estado da fonte, aproveita-se da limitação de alíquota mediante recebimento de dividendos por meio de um intermediário residente em país com o qual o Estado da fonte possui convenção vigente $e^{401}$.

Nos termos dos Comentários da OCDE à Convenção Modelo, acredita-se que a tributação dos dividendos pelo Estado da fonte à alíquota de 15\% (quinze por cento) é razoável em virtude da sua competência exclusiva para tributar os lucros das sociedades, de acordo com o já analisado artigo $7^{\circ}$. Por sua vez, a tributação reduzida dos dividendos pagos a sociedades em relação a participações societárias relevantes justifica-se em face das finalidades institucionais da OCDE e, de modo geral, dos acordos internacionais para evitar dupla tributação, uma vez que pode ser vista como um incentivo ao fluxo de investimentos internacionais em virtude da redução do efeito cascata da tributação dos lucros auferidos ${ }^{402}$.

No caso de dividendos pagos por sociedades brasileiras, essa limitação de tributação é ineficaz, tendo em vista a já analisada isenção de tributação pelo Imposto sobre a Renda em relação ao pagamento de dividendos a sócios residentes no exterior. Entretanto, quanto aos JSCP, essa norma é plenamente eficaz e deve ser aplicada para reduzir a tributação pelo Imposto sobre a Renda incidente à alíquota de 15\% (quinze por cento). Vale ressaltar que, regra geral, nos acordos firmados pelo Brasil, as limitações de alíquota variam entre $10 \%$ (dez por cento) e 15\% (quinze por cento), com exceção do acordo firmado com o Japão, o qual limita a tributação por esse imposto a 12,5\% (doze vírgula cinco por cento).

Exceção às regras constantes dos parágrafos $1^{\circ}$ e $2^{\circ}$ é feita em relação aos casos em que se verifica a existência de um estabelecimento permanente da sociedade estrangeira, beneficiária efetiva dos dividendos, no Estado da fonte ${ }^{403}$. Nesse caso, desde que os dividendos gerados estejam diretamente ligados a esse estabelecimento permanente,

\footnotetext{
${ }^{401}$ Detalhes sobre a utilização do conceito de beneficiário efetivo no âmbito dos acordos para evitar a dupla tributação pode ser encontrado em SCHOUERI, Luís Eduardo. Planejamento fiscal através de acordos de bitributação: treaty shopping. São Paulo: Ed. Revista dos Tribunais, 1995. p. 156-159.

${ }^{402}$ Comentário da OCDE à Convenção Modelo reproduzido em RAAD, Kees van. op. cit., v. 1, p. 175.

403، 4. The provisions of paragraphs 1 and 2 shall not apply if the beneficial owner of the dividends, being a resident of a Contracting State, carries on business in the other Contracting State of which the company paying the dividends is a resident through a permanent establishment situated therein and the holding in respect of which the dividends are paid is effectively connected with such permanent establishment. In such case the provisions of Article 7 shall apply."
} 
aplicar-se-ão as disposições do já mencionado artigo $7^{\circ}$, em detrimento daquelas do artigo 10.

Quando da celebração, pelo Brasil, de vários dos acordos internacionais para evitar a dupla tributação internacional, vigorava ainda o já analisado sistema clássico de tributação dos lucros auferidos pela sociedade, segundo o qual esses lucros estavam sujeitos à dupla tributação econômica. É exatamente por esse motivo que se acredita que o Brasil tenha estabelecido, como regra geral, nos acordos de que é parte, ressalva que lhe guardasse a competência para tributar na fonte os dividendos $\mathrm{e}$ os lucros de estabelecimentos permanentes instalados em seu território. Atualmente, a previsão de competência pelo Estado na fonte faz sentido apenas em relação aos JSCP, pelos mesmos motivos expostos em relação à limitação de alíquota.

A última exceção à regra geral do artigo 10 está prevista no seu parágrafo $5^{\circ 404} \mathrm{e}$ consiste na exclusão da tributação extraterritorial dos dividendos. Segundo esse parágrafo, o Estado contratante no qual foram gerados os lucros de uma sociedade estrangeira residente no outro Estado contratante não poderá tributar os dividendos distribuídos por essa sociedade, nem mesmo os lucros não distribuídos. Essa tributação é permitida apenas nas hipóteses em que os beneficiários dos dividendos são residentes no Estado de que provêem os lucros ou na medida em que a participação geradora dos dividendos estiver efetivamente ligada a um estabelecimento permanente situado nesse mesmo Estado

\subsubsection{As soluções analisadas pela OCDE em virtude da dupla tributação econômica dos lucros das sociedades}

Conforme analisado nos Capítulos I e II, o sistema clássico de tributação dos lucros das sociedades prevê a sua tributação em dois níveis: na sociedade, como contribuinte autônomo, e no nível dos sócios, sob a forma de dividendos. Também nesses Capítulos foram analisados os sistemas de integração propostos por Henry Tilbery para

\footnotetext{
404“5. Where a company which is a resident of a Contracting State derives profits or income from the other Contracting State, that other State may not impose any tax on the dividends paid by the company, except insofar as such dividends are paid to a resident of that other State or insofar as the holding in respect of which the dividends are paid is effectively connected with a permanent establishment situated in that other State, nor subject the company's undistributed profits to a tax on the company's undistributed profits, even if the dividends paid or the undistributed profits consist wholly or partly of profits or income arising in such other State."
} 
minimizar os efeitos dessa dupla tributação econômica. Alguns desses sistemas foram analisados pela OCDE, para verificar a necessidade de previsão de normas específicas em relação à tributação dos dividendos no âmbito dos acordos para evitar a dupla tributação. São eles: (i) o método da integração parcial das alíquotas diferenciadas; (ii) o método de integração parcial do crédito dos dividendos recebidos.

Em relação ao método das alíquotas diferenciadas, foi considerada a possibilidade de o Estado da fonte proceder à retenção do imposto com base em alíquota superior a $15 \%$ (quinze por cento), de forma a compensar a tributação reduzida no nível da sociedade. Conseqüentemente, a diferença a maior não seria passível de crédito no nível dos sócios.

Entretanto, percebeu-se que esse sistema criaria uma dupla discriminação quanto ao pagamento de dividendos a residentes em países sujeitos ao sistema clássico de tributação. Isso porque, sob a perspectiva do Estado da fonte, os dividendos distribuídos a não-residentes estariam sujeitos a tributação mais elevada, quando comparados aos dividendos distribuídos a residentes no país. Sob a perspectiva do Estado de residência, haveria tributação mais gravosa aos dividendos recebidos de sociedades estrangeiras. Em virtude dessas implicações, a adoção de alíquota majorada foi descartada.

Quanto ao método do crédito dos dividendos recebidos, foi questionada a possibilidade de concessão de crédito do imposto também aos sócios não-residentes, de forma a assegurar uma equiparação de tratamento fiscal em relação aos dividendos pagos a residentes e a não-residentes e, ainda, incentivar os investimentos diretos nesses países. Entretanto, verificou-se que a adoção dessa medida possui implicações que variam em função da legislação interna de cada um dos Estados contratantes. Assim, a implementação da concessão de crédito do imposto também aos sócios não-residentes deve ser resolvida nas negociações bilaterais, conforme sugestão da OCDE. 


\subsubsection{A atribuição de competência aos Estados contratantes em relação à tributação dos juros enquadrados no Artigo 11 da Convenção Modelo da OCDE}

O parágrafo $1^{\mathrm{o} 405}$ do artigo 11 da Convenção Modelo da OCDE define a regra geral de atribuição de competência entre os Estados para a tributação dos juros. Segundo esse parágrafo, assim como acontece em relação aos dividendos, os juros provenientes de um Estado contratante e pagos a um residente do outro Estado contratante poderão ser tributados nesse outro Estado. Para esses fins, a primeira parte do parágrafo $5^{\circ}$ desse mesmo artigo define a origem dos juros em função da residência do devedor e estabelece que serão considerados provenientes de um Estado contratante quando o devedor for residente nesse mesmo Estado $^{406}$.

Similar ao que ocorre em relação aos dividendos, a redação desse artigo nos permite afirmar que a competência, nesse caso, é concorrente. Isso porque, ao utilizar a expressão "poderão ser tributados nesse outro Estado" ${ }^{407}$, definiu-se que o Estado de residência está autorizado a tributar os juros pagos, afastando qualquer competência exclusiva do Estado da fonte para a tributação desses rendimentos ${ }^{408}$. Além disso, a primeira parte do parágrafo $2^{\circ}$ desse mesmo artigo 11 confirma a competência do Estado da fonte para tributar esses juros ${ }^{409}$.

É importante notar que, para fins de aplicação dessa regra, não é necessário o efetivo pagamento dos juros, mas apenas o cumprimento da obrigação de disponibilização dos recursos ao credor nos termos do correspondente contrato ou em conformidade com os costumes $^{410}$.

No Direito Positivo Brasileiro, para fins de tributação na fonte pelo Imposto sobre a Renda, regra geral, a disponibilização pode ser tanto econômica como jurídica, de forma que o mero crédito do rendimento ao beneficiário pode ser tido como fato gerador desse

\footnotetext{
405“'1. Interest arising in a Contracting State and paid to a resident of the other Contracting State may be taxed in that other State”. A redação da Convenção Modelo proposta pela Organização das Nações Unidas é idêntica àquela proposta pela OCDE. Entretanto, a Convenção Modelo proposta pelos Estados Unidos da América prevê a competência exclusiva do Estado de residência para a tributação dos juros."

406“5. Interest shall be deemed to arise in a Contracting State when the payer is a resident of that State. (...)" ${ }^{407}$ Tradução livre do extrato de texto "may be taxed".

${ }^{408}$ Comentário da OCDE à Convenção Modelo reproduzido em RAAD, Kees van. op. cit., v. 1, p. 195-196.

409"2. However, such interest may also be taxed in the Contracting State in which it arises and according to the laws of that State (...)".

410“"The term 'paid' has a wide meaning, since the concept of payment means the fulfillment of the obligation to put funds at the disposal of the creditor in the manner required by contract or by custom". Comentário da OCDE à Convenção Modelo reproduzido em RAAD, Kees van. op. cit., v. 1, p. 196.
} 
imposto. Não se pode confundir o direito do sócio a participar dos lucros com sua efetiva disponibilidade jurídica. Esta somente é concretizada no momento em que é deliberada a sua distribuição.

Os demais parágrafos desse artigo 11 , i.e., parágrafos $2^{\circ}, 4^{\circ}, 5^{\circ}$ e $6^{\circ}$, definem exceções à regra de competência concorrente dos Estados da fonte e da residência, seja por meio de limitação de alíquotas ou imposição de critérios específicos em função da origem dos juros e da existência de estabelecimentos permanentes.

A primeira exceção à regra geral que merece destaque é aquela prevista na parte final do parágrafo $5^{\mathrm{o}^{411}}$, que cuida da origem dos juros. Conforme mencionado, a origem dos juros é definida em função do Estado de residência do devedor. No entanto, segundo a redação desse parágrafo, ela poderá ser atribuída ao Estado em que se localiza o estabelecimento permanente do devedor, desde que (i) a obrigação que dá origem ao pagamento dos juros seja contraída em relação a esse estabelecimento permanente; (ii) caiba a esse estabelecimento permanente o pagamento dos juros. Uma vez definida a origem dos juros segundo o parágrafo $5^{\circ}$, as demais normas do artigo 11 serão aplicadas normalmente.

A segunda exceção à regra geral está prevista no parágrafo $2^{\circ 412}$, que limita a tributação pelo Estado da fonte. Esse Estado, apesar de autorizado a tributar os juros em conformidade com a sua legislação interna, deverá limitar referida tributação à alíquota de $10 \%$ (dez por cento) do valor bruto ${ }^{413}$ dos juros devidos.

Dessa limitação, decorre a principal diferença de tratamento entre os rendimentos qualificados no artigo 10 ou no artigo 11 da Convenção Modelo da OCDE. No caso dos acordos firmados pelo Brasil, regra geral, adota-se a alíquota limite de 15\% (quinze por

\footnotetext{
411،5. Interest shall be deemed to arise in a Contracting State when the payer is a resident of that State. Where, however, the person paying the interest, whether he is a resident of a Contracting State or not, has in a Contracting State a permanent establishment in connection with which the indebtedness on which the interest is paid was incurred, and such interest is borne by such permanent establishment, then such interest shall be deemed to arise in the State in which the permanent establishment is situated."

${ }^{412}$ "2. However, such interest may also be taxed in the Contracting State in which it arises and according to the laws of that State, but if the beneficial owner of the interest is a resident of the other Contracting State, the tax so charged shall not exceed 10 per cent of the gross amount of the interest. The competent authorities of the Contracting States shall by mutual agreement settle the mode of application of this limitation." Apesar de a Convenção Modelo proposta pela Organização das Nações Unidas ser muito semelhante àquele modelo proposto pela OCDE, ela não prevê um limite máximo para a tributação pelo Estado da fonte.

${ }^{413}$ Nos casos em que a legislação interna do Estado da fonte prevê a tributação dos juros sobre o seu valor líquido, deverão ser realizados dois cálculos: (i) imposto devido, de acordo com as normas do acordo aplicável; (ii) imposto devido, de acordo com a legislação interna do Estado da fonte. Dentre esses dois cálculos, deverá ser aplicado aquele que possuir o menor resultado.
} 
cento), ressalvadas exceções previstas em alguns acordos e respectivos protocolos e portarias.

A limitação da tributação dos juros pelo Estado da fonte requer que o beneficiário efetivo desses rendimentos seja residente no outro Estado contratante. Conforme visto anteriormente, essa é uma medida adotada para evitar a utilização abusiva dos acordos por meio da interposição de pessoas residentes nos Estados contratantes. Em outras palavras, busca-se evitar as situações em que o real beneficiário dos juros, sendo residente em país que não possui acordo firmado com o Estado da fonte, aproveita-se da limitação de alíquota mediante recebimento de juros por meio de um intermediário residente em país com o qual o Estado da fonte possui convenção vigente ${ }^{414}$.

A terceira exceção à regra geral prevista no parágrafo $1^{\circ}$ encontra-se no parágrafo $4^{\text {o415 }}$ e também está atrelada à existência de um estabelecimento permanente. Entretanto, trata-se de regra que delimita a aplicação do próprio artigo 11. Segundo esse parágrafo, deverão ser aplicadas as regras previstas no artigo $7^{\circ}$, que trata dos lucros das empresas, quando o beneficiário efetivo dos juros, residente de um Estado contratante, (i) exercer, no outro Estado contratante de que provenham os juros, atividade empresarial por intermédio de um estabelecimento permanente aí situado; (ii) o crédito em relação ao qual os juros são pagos estiver efetivamente ligado a esse estabelecimento permanente. A razão dessa exceção decorre do simples fato de os rendimentos pagos sob essas condições terem, na realidade, natureza de lucro e não de juros.

A quarta e última exceção à regra geral diz respeito ao caráter quantitativo dos juros e está prevista no parágrafo $6^{0^{416}}$ do artigo 11. Essa exceção pode ser traduzida na aplicação do princípio “arm's length",417 aos casos em que o valor dos juros pagos é excessivo em virtude da existência de relação privilegiada entre o credor e o devedor, ou

\footnotetext{
${ }^{414}$ Detalhes sobre a utilização do conceito de beneficiário efetivo no âmbito dos acordos para evitar a dupla tributação pode ser encontrado em SCHOUERI, Luís Eduardo. Planejamento fiscal através de acordos de bitributação: treaty shopping. São Paulo: Ed. Revista dos Tribunais, 1995, p. 156-159.

415، 4. The provisions of paragraphs 1 and 2 shall not apply if the beneficial owner of the interest, being a resident of a Contracting State, carries on business in the other Contracting State in which the interest arises through a permanent establishment situated therein and the debt-claim in respect of which the interest is paid is effectively connected with such permanent establishment. In such case the provisions of Article 7 shall apply."

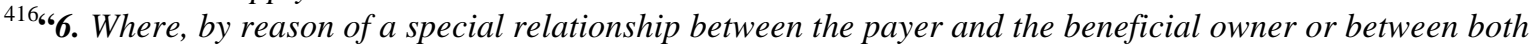
of them and some other person, the amount of the interest, having regard to the debt-claim for which it is paid, exceeds the amount which would have been agreed upon by the payer and the beneficial owner in the absence of such relationship, the provisions of this Article shall apply only to the last-mentioned amount. In such case, the excess part of the payments shall remain taxable according to the laws of each Contracting State, due regard being had to the other provisions of this Convention".

${ }^{417}$ Comentário da OCDE à Convenção Modelo reproduzido em RAAD, Kees van. op. cit., v. 1, p. 208.
} 
entre ambos e qualquer outra pessoa. Como exemplo, podemos citar os já analisados contratos de empréstimos concedidos pelos próprios sócios à sociedade, como forma de redução da carga tributária aplicável a esta última.

Segundo a regra constante do parágrafo $6^{\circ}$, o montante dos juros pagos, que exceder o que teria sido acordado entre o devedor e o beneficiário efetivo na ausência desse relacionamento privilegiado, não estará sujeito às regras do artigo 11, mas às regras previstas na legislação de cada Estado contratante como se fosse qualquer outro rendimento sem previsão específica no texto do acordo. Em outras palavras, as regras do acordo serão aplicáveis apenas ao valor dos juros considerado adequado em virtude da prática comumente adotada entre partes não relacionadas.

Ainda em relação aos juros pagos nos termos desse parágrafo $6^{\circ}$, é importante analisar previsão constante do artigo 24 da Convenção Modelo da OCDE, que trata da vedação ao tratamento discriminatório em relação a sua dedutibilidade.

\subsubsection{O pagamento de juros a residentes no exterior e o principio da não- discriminação na Convenção Modelo da OCDE}

A Convenção Modelo da OECD prevê o princípio da não-discriminação em seu artigo 24. Tal dispositivo é formado por seis diferentes parágrafos, subdivididos em matérias específicas. Ao presente estudo, interessa a regra constante no parágrafo $4^{\circ}$ desse artigo.

Segundo esse dispositivo, os juros, royalties, débitos e outras despesas pagas por uma sociedade de um Estado contratante a um residente do outro Estado contratante devem ser dedutíveis nas mesmas condições como se tivessem sido pagos a um residente do Estado da fonte ${ }^{418}$. Especialmente em relação aos juros, exceção é feita àqueles tratados no parágrafo $6^{\circ}$ do artigo 11 , cujo montante excede o que teria sido acordado entre o devedor e o beneficiário efetivo na ausência de relacionamento privilegiado entre essas partes. Essa

\footnotetext{
418، 4. Except where the provisions of paragraph 1 of Article 9, paragraph 6 of Article 11, or paragraph 4 of Article 12, apply, interest, royalties and other disbursements paid by an enterprise of a Contracting State to a resident of the other Contracting State shall, for the purpose of determining the taxable profits of such enterprise, be deductible under the same conditions as if they had been paid to a resident of the firstmentioned State. Similarly, any debts of an enterprise of a Contracting State to a resident of the other Contracting State shall, for the purpose of determining the taxable capital of such enterprise, be deductible under the same conditions as if they had been contracted to a resident of the first-mentioned State."
} 
regra foi adotada pelo Brasil apenas em relação aos acordos firmados com a África do Sul, Bélgica, Chile, China, Coréia, Israel, México, Portugal e Ucrânia.

A aplicação do disposto no parágrafo $4^{\circ}$ do artigo 24 tem aplicação imediata nos casos em que a legislação interna dos Estados contratantes possui regra que veda a dedutibilidade de juros em virtude da caracterização do estado de subcapitalização nominal.

Apesar de não ser esse o caso do Brasil, a aplicação dessa regra interessa aos juros devidos em virtude de empréstimos contraídos com sociedades controladas ou coligadas residentes no exterior. Isso porque, conforme analisado no Capítulo II, a dedutibilidade dos juros pagos, nesses casos, está condicionada à inexistência de lucros não disponibilizados para a controladora residente no Brasil ${ }^{419}$.

Entretanto, esse tratamento pode ser considerado discriminatório em face da inexistência de critério que justifique a sua indedutibilidade. Nesse sentido, Alberto Xavier $^{420}$ ensina que a indedutibilidade desses juros não é compatível com o próprio regime de transparência fiscal adotado pelo Ordenamento Jurídico Brasileiro, segundo o qual o lucro auferido pela sociedade coligada ou controlada residente no exterior é automaticamente considerado disponibilizado à empresa residente no país.

É importante mencionar que a aplicação da regra do artigo 24 a esses empréstimos decorre do fato de o princípio da não-discriminação produzir efeitos em relação a toda e qualquer situação, ainda que não abrangente pelo correspondente acordo internacional ${ }^{421}$. Nesse sentido, bem afirmou Heleno Taveira Tôrres que, quando um Estado executa uma acordo internacional para evitar a dupla tributação, ele se compromete perante a outra parte a garantir a aplicação do princípio da interdição de tratamento discriminatório sobre qualquer nacional (âmbito subjetivo) e qualquer espécie de tributo aplicável (âmbito objetivo) $^{422}$.

Regra similar a essa pode ser encontrada no Direito Positivo da Holanda e da Bélgica, as quais já foram questionadas na Corte de Justiça Européia.

\footnotetext{
${ }^{419}$ Lei $\mathrm{n}^{\mathrm{o}}$ 9.532/97, artigo $1^{\mathrm{o}}$, parágrafo $3^{\mathrm{o}}$, e Regulamento do Imposto sobre a Renda - Decreto $\mathrm{n}^{\mathrm{o}} 3.000 / 99$, artigo 374, parágrafo único.

${ }^{420}$ XAVIER, Alberto. Direito tributário internacional do Brasil, cit., p. 492-493

${ }^{421}$ TÔRRES, Heleno Taveira. Capital estrangeiro e princípio da não-discriminação tributária no direito interno e nas convenções internacionais. Revista Dialética de Direito Tributário, São Paulo, n. 87, p. 45, dez. 2002.

${ }^{422}$ TÔRRES, Heleno Taveira. Princípio da territorialidade e tributação de não-residentes no Brasil. Prestação de serviços no exterior. Fonte de produção e fonte de pagamento. In: TÔRRES, Heleno Taveira (Coord.). Direito tributário internacional aplicado. São Paulo: Quartier Latin, 2003. p. 104.
} 
No primeiro caso ${ }^{423}$, essa corte determinou ser indevida a restrição prevista na Legislação Holandesa, segundo a qual seriam indedutíveis os custos incorridos em relação a sociedades controladas estrangeiras nas hipóteses em que referidos custos não possuíssem qualquer vínculo com a obtenção de lucros pela sociedade residente naquele país. No segundo caso ${ }^{424}$, a Corte Européia de Justiça também concluiu pela impropriedade da Legislação Belga, que previa a indedutibilidade de juros pagos em virtude de empréstimos concedidos por sociedades subsidiárias ${ }^{425}$.

\footnotetext{
${ }^{423}$ Caso C -168/01 comentado por Kees van Raad em Materials on international \& EC tax Law, cit., v. 2, p. 2379-2384.

${ }^{424}$ Caso C -142/99: Floridienne and Berginvest versus the Belgian State.

${ }^{425}$ Sobre o assunto, veja OKUMA, Alessandra de Souza. op. cit., p. 271.
} 


\section{CONCLUSÃO}

O financiamento de uma sociedade é necessário à sua constituição e manutenção e tem origem em duas principais fontes de recursos: o capital próprio e o capital de terceiros.

A principal diferença entre essas duas fontes de financiamento consiste, basicamente, no fato de o financiamento por meio de capital de terceiros, diferentemente do financiamento realizado por meio de capital próprio, gerar uma obrigação de restituição do valor financiado. É em decorrência dessa diferença que se pode afirmar que o capital aplicado pertencente a terceiros é aquele traduzido no passivo exigível da sociedade, enquanto o capital aplicado de propriedade do titular do patrimônio é aquele delimitado pelo patrimônio líquido.

Essas duas fontes de financiamento também podem ser diferenciadas em virtude de o capital próprio constituir aquele que efetivamente assume o risco da atividade desempenhada pela sociedade. Conforme visto, os clássicos exemplos de investimentos por meio de capital próprio são os aumentos de capital por sócios e a capitalização dos lucros auferidos pela sociedade. Em outras palavras, é o capital investido que efetivamente assume os riscos da sociedade de forma direta, uma vez que tem sua origem no empresário e nos próprios sócios.

Dentre muitas vantagens e desvantagens de se utilizar cada uma dessas fontes de financiamento, o tratamento tributário geralmente vantajoso dispensado à remuneração típica do capital investido com recursos de terceiros ganhou destaque neste trabalho, quando comparado à remuneração do capital próprio. Enquanto este último possui os dividendos como forma tradicional de remuneração, os quais não são dedutíveis para fins tributários, o capital de terceiros, comumente financiado por meio de contratos de mútuo, é remunerado mediante o pagamento de juros passíveis de dedução quando do cálculo do Imposto sobre a Renda devido pela sociedade.

O tratamento tributário benéfico concedido aos investimentos realizados com capital de terceiros despertou, e ainda desperta, a prática do financiamento das sociedades por meio de um volume significativo deste capital. Apesar da clara benesse tributária decorrente dessa prática, as implicações podem ser diversas no campo do Direito Comercial, tendo em vista que os riscos da atividade, inerentes ao capital próprio, podem ser transferidos ao capital de terceiros, em virtude do desrespeito à necessária 
proporcionalidade entre o volume de cada uma dessas fontes de capital, atingindo o estado de subcapitalização.

Essa situação é agravada e ganha importância na seara do Direito Tributário, nas situações em que os sócios realizam investimentos por meio de mútuos, como se fossem investimentos com capital de terceiros, mas cuja essência é da natureza dos financiamentos de capital próprio. Nesse caso, a subcapitalização é classificada como subcapitalização nominal. A sua consequiência é a desqualificação dos juros remuneratórios pagos aos sócios sob esses contratos de mútuo, para qualificá-los como dividendos decorrentes de investimentos efetuados por meio de capital próprio.

Visando desestimular essa prática e incentivar a realização de investimentos de longo prazo por meio de capital próprio, o Governo Brasileiro criou os JSCP nos termos da Lei $n^{\circ}$ 9.249/95. Apesar de, conforme analisado, não ser uma inovação do sistema tributário, a abrangência do seu âmbito de aplicação, quando comparado às figuras anteriores, possibilitou a extinção do tratamento discriminatório que até então era dispensado ao capital próprio.

Para tanto, sob a forma dos JSCP, o Direito Positivo Brasileiro autorizou a dedutibilidade de parcela da remuneração do capital próprio correspondente ao custo de oportunidade do investimento. Ainda, da mesma forma prevista em relação aos juros remuneratórios, também exigiu a sua tributação no nível do beneficiário, por meio do mecanismo de retenção na fonte. Assim, como resultado dessas regras, tem-se a remuneração do capital próprio com tratamento tributário diferenciado e mais benéfico do que aquele dispensado aos dividendos, mesmo diante da isenção tributária aplicável a estes últimos rendimentos.

Figura semelhante aos JSCP é encontrada no Direito Positivo Belga sob a denominação de "déduction pour capital à risque" ou dedução para o capital de risco. A exposição de motivos da lei que a criou, assim como as regras atinentes ao seu cálculo e pagamento, demonstram clara identidade com a figura dos JSCP. Entretanto, a despeito de ter sido criada em 2005, a "déduction pour capital à risque" foi tratada como uma inovação para a eliminação do tratamento discriminatório entre os capitais próprio e de terceiros.

Com base nesse histórico e em análise detalhada das regras atinentes a cada uma das formas de remuneração do capital aplicado, i.e., juros, dividendos e JSCP, concluímos 
que estes últimos são uma forma de remuneração de sócios, diversa dos dividendos e sem qualquer possibilidade de equiparação aos juros advindos dos contratos de mútuo, seja em virtude dos motivos que incentivaram a sua criação, da legislação própria que lhe é aplicável ou em decorrência do fato de serem calculados sobre contas do patrimônio líquido, que, conforme mencionado, representa o capital próprio investido na sociedade.

Entretanto, vimos que a definição da natureza jurídica dos JSCP não é pacífica e, em virtude do seu tratamento tributário diferenciado, a imprecisão quanto a essa definição, principalmente por parte do próprio Governo Brasileiro, pode implicar prejuízo para o contribuinte. As conseqüências são ainda mais drásticas em relação aos JSCP pagos a sócios residentes no exterior, em especial quanto à aplicação dos acordos para evitar a dupla tributação, tendo em vista que os JSCP são uma figura atípica, raramente adotada pelos países estrangeiros.

Sobre esse assunto, concentramos nossa análise na Convenção Modelo da OCDE, que, atualmente, é o modelo de acordo mais utilizado para evitar ou mitigar os efeitos da potencial dupla tributação de rendimentos transnacionais. A sua estrutura, subdividida em artigos que tratam de rendimentos específicos, imputa regras individuais para evitar sua dupla tributação, requerendo adequada qualificação dos rendimentos enviados ao exterior, entre eles os JSCP.

Pelas razões já expostas, a Convenção Modelo da OCDE não prevê um tratamento tributário específico para os JSCP, o que nos levou a analisar detalhadamente os artigos que regulamentam as remessas ao exterior a título de lucros das empresas, dividendos e juros, e concluir pela qualificação dos JSCP como dividendos para fins de aplicação dos acordos a fim de evitar a dupla tributação.

A despeito de, a nosso ver e sob o ponto de vista do Sistema Jurídico Brasileiro, os JSCP terem natureza de remuneração de sócios diversa dos dividendos, na utilização dos acordos para evitar a dupla tributação, deve-se evitar o recurso desenfreado à legislação interna dos Estados contratantes, como forma de mitigar os problemas decorrentes de interpretações divergentes. Assim, a definição de dividendos constante da Convenção Modelo da OCDE, quando comparada àquela prevista para os juros, possibilitou que concluíssemos pela qualificação dos JSCP como dividendos, mas exclusivamente para fins de aplicação desses acordos. 
No caso específico dos acordos firmados pelo Brasil para evitar a dupla tributação, constatamos que a definição de juros é mais abrangente do que aquela da Convenção Modelo da OCDE, uma vez que compreende também os rendimentos que, de acordo com a Legislação Tributária do Estado de que provêm, sejam semelhantes aos rendimentos de importâncias emprestadas.

Apesar de existirem argumentos para afirmar que os JSCP deveriam, em virtude dessa redação diversificada, ser qualificados como juros, e não como dividendos, concluímos que a definição de dividendos deve prevalecer, também em decorrência da utilização subsidiária do reenvio à legislação interna. Ainda, pelos mesmos motivos, é indevida a qualificação expressa dos JSCP como "juros”, incluída nos acordos firmados pelo Brasil com a África do Sul, Bélgica, Chile, Israel, México, Portugal e Ucrânia. 


\section{REFERÊNCIAS BIBLIOGRÁFICAS}

ABREU, Ari Ferreira de. Um estudo sobre a estrutura de capital e a política de dividendos considerando a tributação brasileira. Dissertação (Mestrado) - Faculdade de Economia FEA, Direito, Universidade de São Paulo, São Paulo, 2004.

AMATUCCI, Andrea. La territorialidad en los impuestos directos. In: UCKMAR, Victor; ALTAMIRANO, Alejandro; TORRES, Heleno Taveira (Coord.). Impuestos sobre el comercio internacional. Buenos Aires: Editorial Ábaco, 2003. p. 415-422.

ANAN JÚNIOR, Pedro. Remuneração dos sócios e acionistas e o planejamento fiscal. In: (Coord.). Planejamento fiscal: aspectos teóricos e práticos. São Paulo: Quartier Latin, 2005.

ANDRADE FILHO, Edmar Oliveira. Perfil jurídico do juro sobre o capital próprio: IRPJ, CSLL, PIS, COFINS - aspectos societários. São Paulo: MP Ed., 2006.

ASCARELLI, Tullio. A atividade do empresário. Tradução de Erasmo Valladão A. e N. França do Capítulo VII do Corso di Diritto Commerciale - Introduzione e Teoria dell' Impresa. $3^{\text {a }}$ ed. Milão: Guiffrè, 1962, p. 161-185. Revista de Direito Mercantil, Industrial, Econômico e Financeiro, São Paulo, v. 132, p. 203-215, 2003.

O empresário. Tradução de Fábio Konder Comparato do Corso di Diritto Commerciale - Introduzione e Teoria dell' Impresa. $3^{\mathrm{a}}$ ed. Milão: Guiffrè, 1962, p. 145160. Revista de Direito Mercantil, Industrial, Econômico e Financeiro, São Paulo, v. 109, p. 183-189, 1998.

Origem do direito comercial. Tradução do Capítulo $1^{\circ}$ do Corso di Diritto Commerciale - Introduzione e Teoria dell' Impresa. $3^{\mathrm{a}}$ ed. Milão: Guiffrè, 1962. Revista de direito Mercantil, Industrial, Econômico e Financeiro, São Paulo, v. 103, p. 87-100, 1996.

. Panorama do direito comercial. São Paulo: Saraiva, 1947.

ATALIBA, Geraldo. Hipótese de incidência tributária. 6. ed. São Paulo: Malheiros Ed., 2005.

BABCOCK, Jennifer. The effects of imputation systems on multinational investment, financing, and income-shifting strategies. The Journal of the American Taxation Association, Sarasota, v. 22, n. 2, p. 1-21, Fall 2000. 
BANCO NACIONAL DE DESENVOLVIMENTO ECONÔMICO E SOCIAL - BNDES.

Disponível em: <http://www.bndes.gov.br/produtos/custos/juros/tjlp.asp>.

BASTIANELLO, Cristina Cezar. Juros sobre o capital próprio - natureza jurídica e tratamento conferido pela lei interna e pelos tratados para evitar dupla tributação internacional firmados pela República Federativa do Brasil. In: TÔRRES, Heleno Taveira (Org.). Direito tributário internacional aplicado. São Paulo: Quartier Latin, 2005. v. 3, p. 721-762.

BEATTIE, C. N. Elements of the law of income and capital gains taxation. Londres: Stevens \& Sons Ed. 1968.

BECKER, Alfredo Augusto. Teoria geral do direito tributário. 4. ed. São Paulo: Ed. Noeses, 2007.

BELLAN, Daniel Vitor. Interpretação dos tratados internacionais em matéria tributária. In: TÔRRES, Heleno Taveira. (Org.). Direito tributário internacional aplicado. São Paulo: Quartier Latin, 2005. v. 3, p. 605-665.

BEUREN, Ilse Maria. Conceituação e contabilização do custo de oportunidade. Disponível em: <http://www.eac.fea.usp.br/cadernos/completos/cad08/conceituacao.pdf>. Acesso em: 23 maio 2008.

BORBA, José Edwaldo Tavares. Direito societário. 2. ed. Rio de Janeiro: Freitas Bastos, 1995.

BRAGA, Waldir Luiz; NEVES, Guilherme Pereira das. IRPJ/CSLL - remuneração sobre capital próprio - pagamento retroativo - possibilidade. Revista Dialética de Direito Tributário, São Paulo, n. 87, p. 129-141, dez. 2002.

BREAK, George F. Integration of the corporate and personal income taxes. National Tax Journal (pre-1986), Washington, v. 22, n. 1, p. 39-56, Mar. 1969.

BUHLER, Ottmar. Princípios de derecho internacional tributário. Trad. Fernando Cervera Torejon. Madrid: Estudios de Derecho Financiero, 1968.

BULGARELLI, Waldirio. Contratos mercantis. 4. ed. São Paulo: Atlas, 1988.

BURILOVICH, Linda. Planning techniques to avoid the reclassification of shareholder debt as equity. The Tax Adviser, New York, v. 37, n. 12, p. 708-715, 2006. 
CALDERÓN CARRERO, José Manuel. La doble imposición internacional y los métodos para su eliminación. Madrid: McGraw Hill, 1997. p. 54-120.

CAMPOS, Francisco. Direito comercial. Rio de Janeiro: Freitas Bastos, 1957.

CANTO, Gilberto de Ulhôa. Causa das obrigações tributárias. In: SANTOS, J. M. de Carvalho; DIAS, José de Aguiar (Dirs.). Repertório Enciclopédico do Direito Brasileiro. Rio de Janeiro: Borsoi, 1947-. v. 8, p. 2-25.

Temas de direito tributário. Rio de Janeiro: Ed. Alba, 1964. v. 1.

CARVALHO, Fábio Junqueira de; MURGEL, Maria Inês. IRPJ: teoria e prática jurídica. São Paulo: Dialética, 1999.

CARVAlHO, Paulo de Barros. Curso de direito tributário. 14. ed. São Paulo: Saraiva, 2002.

. Curso de direito tributário. 15. ed. São Paulo: Saraiva, 2003.

Direito tributário: fundamentos jurídicos da incidência. 2. ed. São Paulo: Ed. Saraiva, 1999.

CARVAlHOSA, Modesto. Comentários à lei de sociedade anônimas. 4. ed. São Paulo: Saraiva, 2007. v. 1, 3.

. Comentários à lei de sociedade anônimas: artigos $1^{\circ}$ a 74. 4. ed. São Paulo: Saraiva, 2007. v. 1.

CASÁS, José Osvaldo. La territorialidad en los impuestos directos en Argentina. In: UCKMAR, Victor; ALTAMIRANO, Alejandro; TORRES, Heleno Taveira (Coord.). Impuestos sobre el comercio internacional. Buenos Aires: Editorial Ábaco, 2003. p. 451492.

CEZAROTI, Guilherme. Subcapitalização de empresas. In: COSTA, Alcides Jorge, (Coord.). Direito tributário atual. São Paulo: Dialética, 2004. v. 18., p. 173-188.

COELHO, Fábio Ulhôa. Curso de direito comercial. 11. ed. São Paulo: Saraiva, 2007. v. 1 e 2 .

CÔELHO, Sacha Calmon Navarro. Noções da fiscalidade internacional. Belo Horizonte: UFMG, 1998. 
COMPARATO, Fábio Konder; SALOMÃO FILHO, Calixto. O poder de controle na sociedade anônima. 4. ed. Rio de Janeiro: Forense, 2005.

COSTA JR., Jorge Vieira da. Dividendos e juros sobre o capital próprio: como computálos corretamente? ( $1^{\mathrm{a}}$ parte). Boletim IOB: Temática Contábil e Balanços, São Paulo, v. 38, n. 7, p. 1-10, fev. 2004.

Dividendos e juros sobre o capital próprio: como computá-los corretamente? ( $2^{\mathrm{a}} \mathrm{e}$ última parte). Boletim IOB: Temática Contábil e Balanços, São Paulo, v. 38, n. 6, p. 1-10, fev. 2004.

COSTA, Alcides Jorge. Os acordos para evitar a bitributação e a cláusula de nãodiscriminação. Revista Dialética de Direito Tributário, São Paulo, n. 6, p. 7-10, mar. 1996.

COZIAN, Maurice. Propôs désobligeants sur une «tarte à la crème»: l'autonomie et le réalisme du droit fiscal. Revue Droit Fiscal, Paris, n. 13, p. 530-535, 1999.

DAMODARAN, Aswath. Country risk and company exposure: theory and practice. Journal of Applied Finance, Tampa, v. 13, n. 2, 2003.

. Value and risk: beyond betas. Financial Analysts Journal, Charlottesville, v. 61, n. 2, p. 38-44, Mar./Apr. 2005.

DEL FIORENTINO, Marcelo Fróes. Dividendos versus juros sobre o capital próprio e a problemática correlata referente ao disposto no artigo 17 da lei n. ${ }^{\circ} 11.051 / 04$. Revista Dialética de Direito Tributário, São Paulo, n. 123, p. 64-72, dez. 2005.

DELlA VALlE, Francesca; DELlA VALLE, Sandra. Codice Civile annotato con la jurisprudenza. Milano: Giuffrè, 2005.

DICKINSON, J. P.; KYUNO, K.; MILLER, M. H.; MODIGLIANI, F. Corporate valuation: a reconciliation of the Miller-Modigliani and traditionalist views. Journal of Business Finance \& Accounting, Oxford, v. 4, Summer 1977.

DINIZ, Gustavo Saad. Subcapitalização societária. 2007. Tese (Doutorado), Faculdade de Direito, Universidade de São Paulo, São Paulo, 2007.

DORNELLES, Francisco Neves. A dupla tributação internacional da renda. Rio de Janeiro: Ed. da Fundação Getúlio Vargas, 1979. 
EIZIRIK, Nelson. Reforma das S.A. do mercado de capitais. 2. ed. Rio de Janeiro: Renovar, 1998.

ENGLEBRECHT, Ted D.; CHIANG, Wei-Chih. Use a business-risk perspective to distinguish debt from equity. Practical Tax Strategies, Boston, v. 79, n. 4, Oct 2007.

FELDSTEIN, Martin; FRISCH, Daniel. Corporate tax integration: the estimated effects on capital accumulation and tax distribution of two integration proposals. National Tax Journal (pre-1986), Washington, v. 30, n. 1, p. 37-52, Mar 1977.

FERRARA JR., Francesco. Gli impreditori e le società. Milano: Giuffrè, 1975.

FERREIRA, Aurélio Buarque de Holanda. Miniaurélio século XXI: o minidicionário da língua portuguesa. 4. ed. Rio de Janeiro: Nova Fronteira, 2000.

ـ Novo dicionário da língua portuguesa. 2. ed. Rio de Janeiro: Nova Fronteira, 1986.

FERRI, Giuseppe. Manuale di diritto commerciale. 4. ed. Torino: UnioneTipograficoEditrice Torinese, 1976.

- Le societá - Trattato di diritto civile. Torino: UnioneTipografico-Editrice Torinese, 1971. n. 3, v. 10.

FREITAS, Rodrigo. Conceitos de direito tributário e direito privado. COSTA, Alcides Jorge, (Coord.). Direito tributário atual. São Paulo: Dialética, 2004. v. 18. p. 335-358.

FURUTA, Fernanda. Estudo da consolidação proporcional nas empresas que atuam no mercado brasileiro. 2005. Dissertação (Mestrado) - Faculdade de Economia - FEA, Universidade de São Paulo, São Paulo, 2005.

GARBARINO, Carlo. La tassazione del reddito transnazionale. Padova: CEDAM, 1990.

GARRÁN, Felipe Turbuk. Metodologias em uso no Brasil para a determinação do custo de capital próprio para avaliação de ativos por fluxo de caixa descontado. 2006. Dissertação (Mestrado) - Faculdade de Economia - FEA, Universidade de São Paulo, São Paulo, 2006.

GASTINEAUS, Gary L.; KRITZMAN, Mark P. Dicionário de administração e fisco financeiro. São Paulo: Ed. BM\&F, 1999. 
GERKEN, Luder; MARKT, Jorg; SCHICK, Gerhard. Double income taxation as a response to tax competition in the EU. Intereconomics, Hamburg, v. 36, n. 5, p. 244-354, Sept./Oct. 2001.

GERMANO, Livia De Carli; SHINGAKI, Mário. Juros sobre capital próprio. Disclosure das Transações Financeiras, São Paulo, v. 10, n. 116/117, p. 1-4, jul./ago. 2005.

GEST, Guy; TIXIER, Gilbert. Droit fiscal international. Paris: PUF, 1990.

GOMES, Orlando. Introdução ao direito civil. 10. ed. Rio de Janeiro: Ed. Forense, 1988.

HAMAEKERS, Hubert. The source principle versus the residence principle. Cadernos de Direito Tributário e Finanças Públicas, São Paulo, n. 3, p. 164-175, abr./jun. 1993.

HERERA MOLINA, Pedro M. STJCE 12.12.2002, Lankhorst-Hohorst, As. C-324/00: cláusula de subcapitalización contraria a La libertad de establecimiento. In: TÔRRES, Heleno Taveira. (Org.). Direito tributário internacional aplicado. São Paulo: Quartier Latin, 2004. v. 2, p. 491-501.

HÜBERT, Ivens Henrique. Subcapitalização de empresas: delineamento e tratamento nos âmbitos societário e tributário. In: TÔRRES, Heleno Taveira. (Org.). Direito tributário internacional aplicado. São Paulo: Quartier Latin, 2004. v. 2, p. 563-604.

IUDÍCIBUS, Sérgio de; MARTINS, Eliseu; GELBCKE, Ernesto Rubens. Manual de contabilidade das sociedades por ações. 7. ed. São Paulo: Atlas, 2007.

; ___ K KANITZ, Stephen Charles; RAMOS, Alkíndar de Toledo; CASTILHO, Edison; BENATTI, Luiz; WEBER FILHO, Eduardo; DOMINGUES JÚNIOR, Ramon. Contabilidade introdutória. 9. ed. São Paulo: Atlas, 1998.

JASMON, Abadan; SHAIKH, Junaid M. Tax strategies to discourage thin capitalization. Journal of International Taxation, Boston, v. 14, n. 4, p. 37-44, Apr 2003.

JUNQUEIRA DE AZEVEDO, Antônio. Negócio jurídico: existência, validade e eficácia. 4. ed. São Paulo: Saraiva, 2002.

KAYO, Eduardo Kazuo. A estrutura de capital e o risco das empresas tangível e intangível-intensivas: uma contribuição ao estudo da valoração de empresas. 2002. Dissertação (Mestrado) - Faculdade de Economia - FEA, Universidade de São Paulo, São Paulo, 2002. 
KINGSTON, Suzanne. A light in the darkness: recent developments in the ECJ's direct tax jurisprudence. Common Market Law Review, New York, v. 14, n. 5, p. 1321-1360, Oct 2007.

KPMG. Disponível em: <http://www.kpmg.be>.

KRUPSKY, Kenneth J. How do you say "Interest-Stripping" in German? Tax Management International Journal, Washington, v. 36, n. 9, p. 449-450, Sept. 14, 2007.

LAMY FILHO, Alfredo. Temas de S.A.: exposições e pareceres. Rio de Janeiro: Renovar, 2007.

; PEDREIRA, José Luiz Bulhões. A lei das S.A. Rio de Janeiro: Renovar, 1992.

LANG, Michael. Os trabalhos da OECE e da OCDE para a criação das vedações de discriminação. Revista de Direito Tributário Internacional, São Paulo, n. 3, p. 221-241, 2006.

LAUFENBURGER, Henry. Finanças comparadas. 2. ed. Rio de Janeiro: Ed. Financeiras, 1953.

LEÃES, Luiz Gastão Paes de Barros. Do direito do acionista ao dividendo. São Paulo: Obelisco Ed., 1969.

LIPTON, Richard M.; DIXON, Steven R. When is a partner not a partner? When does a partnership exist? Journal of Taxation, New York, v. 100, n. 2, p. 73-84, Feb 2004.

LUCAS DURÁN, Manuel. Libertad de establecimiento; normas tributárias sobre subcapitalización; distribución encubierta de benefícios; coherencia del régimen fiscal; evasión fiscal - STJCE Lankhorst-Hohorst versus Finanzamt Steinfurt, de 12-12-2002, As. C-324/00. In: TÔRRES, Heleno Taveira. (Org.). Direito tributário internacional aplicado. São Paulo: Quartier Latin, 2004. v. 2, p. 351-364.

LUCENA, José Waldecy. Das sociedades limitadas. 6. ed. Rio de Janeiro: Ed. Renovar, 2005 .

MACHADO, Hugo de Brito. Tratados e convenções internacionais em matéria tributária. Revista Dialética de Direito Tributário, São Paulo, n. 93, p. 25-33, jun., 2003.

MARTINS, Eliseu. Origem do modelo brasileiro de correção monetária das demonstrações financeiras. Boletim IOB: temática contábil e balanços, São Paulo, ano 38, n. 45, p. 1-7, nov. 2004. 
MARTINS, Eliseu. Um pouco de história dos juros sobre o capital próprio. Boletim IOB: temática contábil e balanços, São Paulo, ano 38, n. 49, p. 1-7, dez. 2004.

MARTINS, Fran. Comentários à lei das sociedades anônimas. Rio de Janeiro: Ed. Forense, 1977, v.1.

. Curso de direito comercial. 1. ed. Rio de Janeiro: Ed. Forense, 1993.

MARTINS, Vinícius Aversari. Interações entre estrutura de capital, valor da empresa e valor dos ativos. 2005. Tese (Doutorado) - Faculdade de Economia - FEA, Universidade de São Paulo, São Paulo, 2005.

MASSANET, Juan Ramallo. Derecho fiscal frente a derecho civil: discusion em torno a La natuerleza Del derecho fiscal entre L. Trotabas y F. Gény. Revista da Faculdad de Derecho de la Universidad Complutense de Madrid, Madrid, v. 17, p. 7-102, 1973.

McLURE JR., Charles. The case for integrating the income taxes. National Tax Journal (pre-1986), Washington, v. 28, n. 3, p. 257-264, Sept. 1975.

Must corporate income be taxed twice?: a Report of a Conference Sponsored by the Fund of Public Research and the Brookings Institution. Brookings Institution Press, 1979.

. A status report on tax integration in the United States. National Tax Journal (pre1986), Washington, v. 31, n. 4, p. 313-328, dez. 1978.

MELO, José Eduardo Soares de. Curso de direito tributário. 5. ed. São Paulo: Ed. Dialética, 2004.

MENDONÇA, J. X. Carvalho de. Tratado de direito comercial brasileiro. 4 . ed. Rio de Janeiro: Ed. Freitas Bastos, 1947. v. 6.

MILLER, Merton H.; MODIGLIANI, Franco. Dividend policy and market valuation: a reply. The Journal of Business (pre-1986), Chicago, v. 36, n. 1, p. 116-120, Jan 1963.

; _ Dividend policy, growth, and the valuation of shares. The Journal of Business (pre-1986), Chicago, v. 34, n. 4, p. 411-424, Oct. 1961.

MINISTÉRIO DA FAZENDA. Receita Federal. Disponível em: $<$ http://www.receita.fazenda.gov.br>. 
MIRANDA, Francisco Cavalcanti Pontes de. Tratado de direito privado. 3. ed. São Paulo: Ed. Revista dos Tribunais, 1984. v. 2, 5, 42, 49, 50.

MOOIJ, Ruud A. De. Will corporate income taxation survive? De Economist, Leiden, v. 153, n. 3, p. 277-301, Sept. 2005.

NEVES, Silvério das. Juros sobre o capital próprio. In: ANAN JUNIOR, Pedro. (Coord.). IRPJ: teoria e prática. São Paulo: Quartier Latin, 2006. p. 324-344.

OKUMA, Alessandra de Souza. Princípio da não-discriminação internacional no direito brasileiro. 2005. Dissertação (Mestrado) - Pontifícia Universidade Católica - PUC/SP, São Paulo, 2005.

- Princípio da não-discriminação e a tributação das rendas de não-residentes no Brasil. In: TÔRRES, Heleno Taveira. (Org.). Direito tributário internacional aplicado. São Paulo: Quartier Latin, 2003. v. 1, p. 255-285.

Tributação dos dividendos remetidos aos não-residentes. Comentários à decisão do Superior Tribunal de Justiça no Recurso Especial n. ${ }^{\circ}$ 60.725/PR. In: TÔRRES, Heleno Taveira. (Org.). Direito tributário internacional aplicado. São Paulo: Quartier Latin, 2005. v. 3, p. 341-358.

OLIVEIRA, José Marcos Domingues de. Enquadramento fiscal da subcapitalização das empresas. Revista Dialética de Direito Tributário, São Paulo, n. 41, p. 17-26, fev. 1999.

OLIVEIRA, Ricardo Mariz de. A tributação dos lucros distribuídos face aos acordos para evitar a dupla tributação - as cláusulas de não discriminação. Repertório $I O B$ de jurisprudência, São Paulo, n. 5, p. 85-84, 1ª quinz. mar., 1991.

PEDREIRA, José Luiz Bulhões. Finanças e demonstrações financeiras da companhia. Rio de Janeiro: Forense, 1989.

PENTEADO, Mauro Rodrigues. Aumentos de capital das sociedades anônimas. São Paulo: Saraiva, 1988.

PIRES, Manuel. Da dupla tributação jurídica internacional sobre o rendimento. Lisboa: Centro de Estudos Fiscais, 1987. 
POHLMANN, Marcelo Coletto. Contribuição ao estudo da classificação interdisciplinar da pesquisa tributária e do impacto da tributação na estrutura de capital das empresas no Brasil. 2005. Tese (Doutorado) - Faculdade de Economia - FEA, Universidade de São Paulo, São Paulo, 2005.

PRATT, Shannon Pease, D.B.A. Relationship between risk and rate of return for common stocks. Indiana University, 1967.

RAAD, Kees van. Materials on international \& EC tax law. 6. ed. Leiden: International Tax Center Lieden, 2006. v. 1, 2.

REIS, Caimi Franco. Generalização do CAPM aplicada ao cálculo do custo de capital do setor de telefonia fixa do Brasil. 2006. Dissertação (Mestrado) - EP, Universidade de São Paulo, São Paulo, 2006.

REQUIÃO, Rubens. Curso de direito comercial. 27. ed. São Paulo: Ed. Saraiva, 2007. v. $1,2$.

RIBEIRO, Antônio Carlos Silva. Aspectos tributários da subcapitalização no sistema jurídico alemão e brasileiro. Revista de Direito Tributário Internacional, São Paulo, ano 3, n. 9, p. 11-50, 2008.

RODRIGUES, Silvio. Direito civil - dos contratos e das declarações unilaterais de vontade. 30. ed. São Paulo: Saraiva, 2004. v. 3.

ROLIM, João Dácio. A remuneração do capital próprio das pessoas jurídicas e a revogação da correção monetária de balanço pela Lei n ${ }^{\circ}$ 9.249/95. Repertório IOB de jurisprudência, São Paulo, n. 16, 2. P. 392, quinz. ago., 1996.

ROTHMANN, Gerd W. Interpretação e aplicação dos acordos internacionais contra a bitributação. 1978. Tese (Doutorado) - Faculdade de Direito, Universidade de São Paulo, São Paulo, 1978.

Problemas de qualificação na aplicação das convenções contra a bitributação internacional. Revista Dialética de Direito Tributário, São Paulo, n. 76, p. 33-43, jan. 2002.

SACCHETTO, Claudio. La territorialidad de la imposición. In: UCKMAR, Victor; ALTAMIRANO, Alejandro; TORRES, Heleno Taveira (Coord.). Impuestos sobre el comercio internacional. Buenos Aires: Editorial Ábaco, 2003. p. 43-77. 
SAINZ DE BUJANDA, Fernando. Sistema de derecho financeiro. Madrid, 1985. v. 1, p. $5-228$.

SALLES, Marcos Paulo de Almeida. Política de Dividendos - função econômica do dividendo, Revista de Direito Bancário do Mercado de Capitais e da Arbitragem, São Paulo, n. 14, p. 79-89, 2001.

SANTOS, Ariovaldo. Quem está pagando juros sobre o capital próprio no Brasil? Revista de Contabilidade de Finanças, São Paulo, n. 43, p. 33-44, jun. 2007.

; SILVA, Fabiana Lopes da. Aspectos práticos da demonstração do valor adicionado - distribuição de lucros (juros sobre o capital próprio e dividendos) e doações e subvenções para investimentos. ( $2^{\mathrm{a}}$ e última parte). IOB: informações objetivas. Temática Contábil e Balanços, São Paulo, v. 37, n. 16, p. 1-6, abr., 2003.

; __ Aspectos práticos da demonstração do valor adicionado - distribuição de lucros (juros sobre o capital próprio e dividendos) e doações e subvenções para investimentos. ( $1^{\mathrm{a}}$ parte). IOB: informações objetivas. Temática Contábil e Balanços, São Paulo, v. 37, n. 15, p. 2 e 9, abr. 2003.

SANTOS, J. M. de Carvalho. Código Civil brasileiro interpretativo. 8. ed. Rio de Janeiro: Ed. Freitas Bastos, 1964. v. 17.

SCHERER, Luciano Márcio; MARTINS, Eliseu. Manutenção de capital e distribuição de dividendos. Revista da FAE, Curitiba, v. 6, n. 2, p. 65-83, maio/dez., 2003.

SCHOUERI, Luís Eduardo. Direito tributário internacional - qualificação e substituição tributação, no Brasil, de rendimentos provenientes de sociedade de pessoas residente na Alemanha. Revista Dialética de Direito Tributário, São Paulo, n. 54, p. 125-139, mar. 2000.

Discriminação de competências e competência residual. In: ; ZILVETI,

Fernando Aurélio (Coord.). Direito Tributário: estudos em homenagem a Brandão Machado. São Paulo: Ed. Dialética, 1998. p. 82-115.

Planejamento fiscal através de acordos de bitributação: treaty shopping. São Paulo: Ed. Revista dos Tribunais, 1995.

Preços de transferência no direito tributário brasileiro. 2. ed. São Paulo: Ed. Dialética, 2006. 
SCHOUERI, Luís Eduardo. Princípios no direito tributário internacional: territorialidade, fonte e universalidade. In: FERRAZ, Roberto Catalano Botelho (Coord.). Princípios e limites da tributação. São Paulo, Quartier Latin, 2005. p. 329-363.

SELIGMAN, Edwin R. A. The income tax, history, theory and practice. 2. ed. New York: A. M. Kelly, 1970.

SILVA, De Plácido e. Noções práticas de direito comercial. 12. ed. Rio de Janeiro: Forense, 1965. v. 1.

SILVA, Genison Augusto Couto. Tratamento tributário de juros sobre capital próprio e dividendos pagos a domiciliado no exterior. Revista Dialética de Direito Tributário, São Paulo, n. 57, p. 64-71, jun. 2000.

SILVA, Severino. Juros sobre o capital próprio (art. $9^{\circ}$ da lei n. ${ }^{\circ}$ 9.249/95) - aspectos tributários e questões societárias. Revista Dialética de Direito Tributário, São Paulo, n. 21, p. 79-82, jun. 1997.

SILVEIRA, Rodrigo Maitto da. Aplicação de tratados internacionais contra a bitributação: qualificação de partnerships joint ventures. São Paulo: Ed. Quartier Latin, 2006.

SURREY, Stanley S. Reflections on "integration" of corporation and individual income taxes. National Tax Journal (pre-1986), Washington, v. 28, n. 3, p. 335-340, Sept. 1975.

SZTAJN, Rachel; PELIZZARO, Renato S. Juros sobre capital próprio. Revista de Direito Mercantil, Industrial, Econômico e Financeiro, São Paulo, v. 145, p. 251, 2007.

TEIXEIRA, Egberto Lacerda; GUERREIRO, José Alexandre Tavares. Das sociedades anônimas no direito brasileiro. São Paulo: José Bushatsky, 1979. v. 1, 2.

TILBERY, Henry. Imposto de renda, pessoas jurídicas; integração entre sociedade e sócios. São Paulo: Atlas, 1985.

TÔRRES, Heleno Taveira. Aplicação dos tratados internacionais em matéria tributária: o procedimento de interpretação. Revista da ABNT, Belo Horizonte, Del Rey, v. 1, p. 109136, 1998.

Aplicação dos tratados internacionais em matéria tributária: o procedimento de interpretação. Revista da ABNT, Belo Horizonte, Del Rey, v. 1, p. 109-136, 1998. 
TÔRRES, Heleno Taveira. A convenção Brasil-Alemanha e sua aplicação em face do direito brasileiro. Revista de Direito Tributário, São Paulo, n. 83, p. 102-133, 1995.

- Direito tributário e direito privado: autonomia privada, simulação, elusão tributária. São Paulo: Ed. Revista dos Tribunais, 2003.

- Direito tributário internacional: planejamento tributário e operações transnacionais. São Paulo: Ed. Revista dos Tribunais, 2001.

Funções das leis complementares no sistema tributário nacional - hierarquia de normas - papel do Código Tributário Nacional no ordenamento. Revista de Direito Tributário, São Paulo, n. 84, p. 50-69, 1995.

. Juros sobre capital próprio - autonomia privada nos investimentos societários e suas implicações em matéria tributária. In: TÔRRES, Heleno Taveira. (Org.). Direito tributário internacional aplicado. São Paulo: Quartier Latin, 2007. v. 4, p. 349-408.

. Pluritributação internacional sobre as rendas de empresas. 2. ed. São Paulo: Ed. Revista dos Tribunais, 2001.

Princípio da territorialidade e tributação de não-residentes no Brasil. Prestação de serviços no exterior. Fonte de produção e fonte de pagamento. In: TÔRRES, Heleno Taveira (Coord.). Direito tributário internacional aplicado. São Paulo: Quartier Latin, 2003.

A tributação dos não-residentes no Brasil: o regime fiscal dos dividendos, juros, "royalties" e "capital gains". Revista de Direito Tributário, São Paulo, n. 76, p. 102-127, 1994.

. Tratados e convenções internacionais em matéria tributária e o federalismo fiscal brasileiro. Revista Dialética de Direito Tributário, São Paulo, n. 86, p. 34-49, nov. 2002.

UTUMI, Ana Cláudia Akie. O regime tributário brasileiro do imposto sobre a renda de não-residente: a fonte como critério de conexão. 2006. Tese (Doutorado) - Faculdade de Direito, Universidade de São Paulo, São Paulo, 2006.

VALLE, Mauricio Ribeiro do. Estrutura de capital de empresas brasileiras num ambiente de altas taxas de juros e na presença de fontes diferenciadas de financiamento. 2008. Tese (livre-docência) - Faculdade de Economia - FEA, Universidade de São Paulo, São Paulo, 2008 . 
VALVERDE, Trajano de Miranda. Sociedade por ações: comentários ao Decreto-Lei 2.627, de 26 de setembro de 1940. Rio de Janeiro: Forense, 1941. v. 2.

VENOSA, Sílvio de Salvo. Direito civil: contratos em espécie. 7. ed. São Paulo: Atlas, 2007. v. 3.

VERÇOSA, Haroldo Malheiros Duclerc. Curso de direito comercial. São Paulo: Malheiros Ed., 2004. v. 1.

VIVANTE, Cesare. Trattato di diritto commerciale: le società commerciali. 5. ed. Milano: Francesco Vallardi, 1929. v. 2.

VOGEL, Klaus. On double taxation conventions: a commentary to the OECD, UN and US Model Conventions for the avoidance of double taxation of income and capital (with particular reference to German Treaty Practice). 3. ed. Boston: Kluwer, 1996.

. World-wide or source taxation of income? Rassegna Tributaria, Roma, v. 31, p. 259-266, 1988.

WALD, Arnoldo. Direito civil: contratos em espécie. 18. ed. São Paulo: Saraiva, 2009. v. 3.

Obrigações e contratos. 5. ed. São Paulo: Ed. Revista dos Tribunais, 1979.

XAVIER, Alberto. Direito tributário internacional do Brasil. 6. ed. Rio de Janeiro: Forense, 2005.

. O imposto de renda na fonte e os serviços internacionais - análise de um caso de equivocada interpretação dos arts. $7^{\circ}$ e 21 dos tratados. Revista Dialética de Direito Tributário, São Paulo, n. 49, p. 7-17, out. 1999.

Inexistência jurídica e inconstitucionalidade da denuncia do tratado contra a dupla tributação entre Brasil e Portugal. Revista Dialética de Direito Tributário, São Paulo, n. 48, p.7-48, set. 1999.

Natureza jurídico-tributária dos “juros sobre o capital próprio" face à lei interna e aos tratados internacionais. Revista Dialética de Direito Tributário, São Paulo, n. 21, p. 7, jun. 1997.

XAVIER, José Tadeu Neves. A teoria da desconsideração da pessoa jurídica no novo Código Civil. Ajuris: Revista da Associação dos Juízes do Rio Grande do Sul, Porto Alegre, ano 30, n. 89, p. 169-184, mar. 2003. 